\title{
ANDEAN STATES AND THE RESOURCE CURSE
}

INSTITUTIONAL CHANGE IN EXTRACTIVE ECONOMIES

\author{
Edited by
}

Gerardo Damonte and Bettina Schorr 


\section{Andean States and the Resource Curse}

This volume explores institutional change and performance in the resource-rich Andean countries during the last resource boom and in the early post-boom years.

The latest global commodity boom has profoundly marked the face of the resource-rich Andean region, significantly contributing to economic growth and notable reductions of poverty and income inequality. The boom also constituted a period of important institutional change, with these new institutions sharing the potential of preventing or mitigating the maladies extractive economies tend to suffer from, generally denominated as the "resource curse". This volume explores these institutional changes in the Andean region to identify the factors that have shaped their emergence and to assess their performance. The interdisciplinary and comparative perspective of the chapters in this book provide fine-grained analyses of different new institutions introduced in the Andean countries and discusses their findings in the light of the resource curse approach. They argue that institutional change and performance depend upon a much larger set of factors than those generally identified by the resource curse literature. Different, domestic and external, economic, political and cultural factors such as ideological positions of decision-makers, international pressure or informal practices have shaped institutional dynamics in the region. Altogether, these findings emphasize the importance of nuanced and contextualized analysis to better understand institutional dynamics in the context of extractive economies.

This book will be of great interest to students and scholars of the extractive industries, natural resource management, political economics, Latin American studies and sustainable development.

Gerardo Damonte is a professor of the Department of Social Sciences at Pontificia Universidad Católica del Perú (PUCP). He holds a PhD in anthropology from Cornell University. Currently, he acts as a member of the trAndeS Executive Committee and he is affiliated with the Development Analysis Group (GRADE) based in Lima. His research addresses socioenvironmental issues in Latin America, particularly the social dynamics linked to global extractive development.

Bettina Schorr holds a PhD in political science from the Department of International Relations and Foreign Policy Analysis of Universität zu Köln, Germany. Her research interests include social inequalities and sustainable development, institutional change and dynamics of social conflicts (contentious politics). Currently, she is a lecturer at the Institute for Latin American Studies at Freie Universität Berlin, Germany, and the program director of trAndeSPostgraduate Program on Social Inequalities and Sustainable Development in the Andean Region. 
Routledge Studies of the Extractive Industries and Sustainable Development

Regime Stability, Social Insecurity and Bauxite Mining in Guinea

Developments Since the Mid-Twentieth Century

Penda Diallo

Local Experiences of Mining in Peru

Social and Spatial Transformations in the Andes

Gerardo Castillo Guzmán

Resource Extraction, Space and Resilience

International Perspectives

Juha Kotilainen

Our Extractive Age

Expressions of Violence and Resistance

Edited by Judith Shapiro and John-Andrew McNeish

The Impact of Mining Lifecycles in Mongolia and Kyrgyzstan

Political, Social, Environmental and Cultural Contexts

Edited by Troy Sternberg, Kemel Toktomushev and Byambabaatar Ichinkhorloo

Oil and National Identity in the Kurdistan Region of Iraq

Conflicts at the Frontier of Petro-Capitalism

Alessandro Tinti

The Anthropology of Resource Extraction

Edited by Lorenzo D'Angelo and Robert Jan Pijpers

Andean States and the Resource Curse

Institutional Change in Extractive Economies

Edited by Gerardo Damonte and Bettina Schorr

For more information about this series, please visit: www.routledge.com/RoutledgeStudies-of-the-Extractive-Industries-and-Sustainable-Development/book-series/ REISD 


\section{Andean States and the Resource Curse}

Institutional Change in Extractive Economies

Edited by Gerardo Damonte and Bettina Schorr 
First published 2022

by Routledge

2 Park Square, Milton Park, Abingdon, Oxon OX14 4RN

and by Routledge

605 Third Avenue, New York, NY 10158

Routledge is an imprint of the Taylor E Francis Group, an informa business

(C) 2022 selection and editorial matter, Gerardo Damonte and Bettina

Schorr; individual chapters, the contributors

The right of Gerardo Damonte and Bettina Schorr to be identified as the authors of the editorial material, and of the authors for their individual chapters, has been asserted in accordance with sections 77 and 78 of the Copyright, Designs and Patents Act 1988.

The Open Access version of this book, available at www.taylorfrancis. com, has been made available under a Creative Commons Attribution-Non Commercial-No Derivatives 4.0 license.

Trademark notice: Product or corporate names may be trademarks or registered trademarks, and are used only for identification and explanation without intent to infringe.

British Library Cataloguing-in-Publication Data

A catalogue record for this book is available from the British Library

Library of Congress Cataloging-in-Publication Data

A catalog record for this book has been requested

ISBN: 978-1-032-01678-8 (hbk)

ISBN: 978-1-032-01680-1 (pbk)

ISBN: 978-1-003-17955-9 (ebk)

DOI: $10.4324 / 9781003179559$

Typeset in Bembo

by Apex CoVantage, LLC 


\section{Contents}

PART 1

Introduction

1 A curse over the Andes? The resource curse approach and institutional change in the Andean region

PART 2

Empirical studies

2 Fiscal reforms and institutional changes in the Andean region: revenues volatility and unequal distribution of regional income

JUAN PABLO JIMÉNEZ

3 Cash transfers as citizens' dividend of the resource boom: opportunities and challenges of social protection in Bolivia

PABLO EVIA SALAS

4 Growing under the shadow of oil: institutionalizing the mining sector in Ecuador between 2002 and 2019 PAÚl CISNEROS

5 Hybrid institutions: institutionalizing practices in the context of extractive expansion 
6 Prior consultation to halt the resource curse? Potentials and pitfalls of a participatory innovation in Peru and its implications for the Andean countries

7 The curse among citizens: corruption, democracy, and citizen participation in the Andean region

DANIEL E. MORENO MORALES

8 Towards new rules for political transparency:

lessons from anti-corruption initiatives in Peru and Chile

BETTINA SCHORR

9 Between environmental subsystem change and extractive regime resilience: beyond the apparent development of Chilean environmental institutions (1990-2019)

ANTOINE MAILLET AND SEBASTIÁN CARRASCO

10 Strengthening or weakening environmental institutions?

Chile and the establishment and use of environmental courts in an extractive economy

VIOLETA RABI AND FERNANDO CAMPOS

11 New institutions, old practices: the weakening of new environmental control institutions in Peru MARITZA PAREDES AND LORENA FIGUEROA

12 How to institutionalize sustainability? Analyzing the enforcement of reparación integral and environmental law in the hydrocarbon sector in Ecuador TERESA BORNSCHLEGL

13 Changes to the environmental monitoring institutions for the mining sector in San Juan, Argentina JULIETA GODFRID

\section{PART 3}

Conclusions and road ahead

14 Institutional change in extractive economies:

a research agenda from the Andes 


\section{Acknowledgments}

This book started as a conference panel held during the International Conference of the Latin American Studies Association (LASA) in Barcelona in 2018. The chapters underwent revisions after lively discussions in several other workshops and conference panels in the following years in Berlin, Lima, and Boston. During this period, the authors have integrated their empirical studies into the research approach used in this volume, which focuses closely on institutional change and performance in the resource-dependent Andean region. This process was incredibly enriching while also time and again confronting us with the challenges of interdisciplinary work. We are convinced it was worth the effort, so first of all we would like to offer our special thanks to the authors of this volume who kindly accepted to contribute to this collaborative effort.

We also express our deep gratitude to our colleagues at the program trAndeS at FU Berlin and PUCP, Marianne Braig, Barbara Fritz, Narda Henríquez, and Ana Sabogal, for being with us on board of this exciting program and encouraging our work. Another special thank you goes to Hans-Jürgen Puhle, who accompanied us in this project by providing insightful comments and inspiring critics to the books' concept and various of its chapters.

The book would not exist without the support and work of a whole group of people. We are deeply grateful for the professional language editing done by Dr. Paul Talcott from Freie Universität Berlin. As always, Paul did much more than correct our English: He essentially contributed to the improvement of the academic quality of all of the chapters and assisted the management of the editorial process with helpful advice. We also thank Kenneth Hermse for the translation and copy-editing of some of the chapters.

We very much appreciate the support of the student assistants of the program trAndeS at the Institute for Latin American Studies at Freie Universität Berlin: Joana Stalder, Sophie Vey, and Adrian Pusch provided us invaluable support particularly in the formal preparation of the chapters' manuscripts and assisted in the literature review conducted for the introductory chapter. We also thank Adriana Foronda for copy-editing the chapters of the book.

As always, Frauke Berg of the program trAndeS at FU Berlin offered her indefatigable and constant support for which we are extremely grateful. In 
particular, we thank Frauke for her timely interventions in the fine-tuning at the last stages of this book.

Finally, we like to express our gratitude to the anonymous reviewers of our book proposal: They provided important ideas that helped focus the book and improve its argument. At Routledge, we wish to thank John Baddeley and Hannah Ferguson for their kindness and help in navigating the complex process of production of this volume.

This book is a product of the program trAndeS-Advanced Studies on Inequalities and Sustainable Development. TrAndeS is a structured research and training program based at the Pontificia Universidad Católica del Perú (PUCP) with a focus on social inequalities and their impact on the opportunities for sustainable development in the Andean region. The project partners are Freie Universität Berlin and Pontificia Universidad Católica del Perú (PUCP). TrAndeS runs a trans-Andean network on inequality and sustainability (Red trAndeS): The authors assembled in this book form part and promote activities in the frame of this network. TrAndeS is financed by the German Academic Exchange Service (Deutscher Akademischer Austauschdienst, DAAD) with funding from the German Federal Ministry for Economic Cooperation and Development (Bundesministerium für Wirtschaftliche Zusammenarbeit und Entwicklung, BMZ). For this book, we appreciate the generous funding from BMZ and DAAD. This publication was financed in part by the open access fund for monographs and edited volumes of the Freie Universität Berlin.

Lima and Berlin, Gerardo Damonte and Bettina Schorr 


\section{Contributors}

Teresa Bornschlegl holds a MSc in human ecology from Lunds Universitet (Sweden), and a PhD in geography from Clark University (USA). She currently works as a research associate and policy advisor at the Sector Program "Extractives and Development" at the Federal Institute for Geosciences and Natural Resources and is an affiliated researcher of the trAndeS Research Network. Her research focuses on empirically examining the implementation of environmental and social sustainability standards within the extractive sector and corresponding supply chains.

Fernando Campos Medina is Assistant Professor of the Department of Sociology of the Universidad de Chile. He holds a master's degree in housing and urbanism from the Universitat Politècnica de Catalunya, Spain, a PhD in urban planning from the Bauhaus-Universität Weimar and $\mathrm{PhD}$ in sociology from the Friedrich-Schiller-Universität Jena, both in Germany. He has carried out multiple studies in the fields of environmental sociology, urban sociology, human geography, socio-environmental conflicts, and space-time structures of society.

Sebastián Carrasco is a professor at the Department of Sociology, Political Science and Public Administration at Universidad Católica de Temuco. He has a master's degree in political science and is a $\mathrm{PhD}$ candidate in public policy at Universidad Mayor, Chile. He is also a member of Colectivo de Estudios Políticos Ambientales (CEPA). His research focuses on public policy, political economy, and local public management, with special emphasis on environmental issues.

Paúl Cisneros holds a degree in sociology from the Pontificia Universidad Católica del Perú. He received his $\mathrm{PhD}$ in social sciences from FLACSO Ecuador in 2011. Since 2016, he has been a professor of public policy at the School of Government and Public Administration of the Instituto de Altos Estudios Nacionales in Ecuador. His main research topics are related to the design and implementation of public policies related to natural resources.

Gerardo Damonte is Professor of the Department of Social Sciences at Pontificia Universidad Católica del Perú (PUCP). He holds a PhD in 
anthropology from Cornell University and is a member of the trAndeS Executive Committee. Currently, he acts as a member of the trAndeS Executive Committee and he is affiliated with the Development Analysis Group (GRADE) based in Lima. His research addresses socio-environmental issues in Latin America, particularly the social dynamics linked to global extractive development.

Pablo Ernesto Evia Salas holds a PhD in agricultural economics from the Rheinische Friedrich-Wilhelms-Universität Bonn, Germany, and a master's degree in public policy (Universidad Torcuato Di Tella, Buenos Aires, Argentina), and in policy economics (Williams College, Massachusetts, USA). He worked as an economist at the Economic and Social Policy Analysis Unit (UDAPE), as well as Senior Risk Analyst at the Central Bank of Bolivia. Currently, he works as a consultant for international organizations. His areas of interest are poverty, inequality, and governance, among others.

Lorena Figueroa holds a degree in sociology from the Pontificia Universidad Católica del Perú. Currently, she is a master's student in Latin American studies at the Universiteit Leiden, the Netherlands.

Riccarda Flemmer holds a $\mathrm{PhD}$ in political science from the Universität Hamburg, Germany. She has worked as a researcher at the GIGA Institute of Latin American Studies and as a lecturer at the Universität Hamburg. Her research focuses on resource conflicts, indigenous peoples' rights, contested ontologies, and ethnographic methods. Since June 2020, Flemmer has been chair of the Latin American Studies Association's Amazonia section.

Julieta Godfrid obtained a PhD in social science studies from Universidad de Buenos Aires, Argentina. Her research interests span both in sociology and international development. Current research focuses on corporate social responsibility, socio-environmental conflicts, and state-firm relations in Latin America (particularly in Argentina and Chile). She is a postdoctoral FONDECYT researcher at the Centro de Estudios Avanzados, Universidad de Playa Ancha, Chile.

Juan Pablo Jiménez holds a master's degree in public administration from Columbia University and a master's degree in economics from the Di Tella Institute. Currently, he is Professor of Public Finance at the Facultad Latinoamericana de Ciencias Sociales (FLACSO), Argentina and researcher at the Asociación Iberoamericana de Financiación Local (AIFIL). He was Director of the Office of the Economic Commission for Latin America and the Caribbean (ECLAC) in Uruguay and coordinator of the fiscal area of ECLAC's Economic Development Division. He is the author of numerous books, articles, and publications on topics of economic development, fiscal policy, taxation, social policies, inequality, fiscal federalism, and decentralization.

Antoine Maillet is Assistant Professor at the Institute of Public Affairs of the Universidad de Chile. He is also associate researcher at the Centro de Estudios de Conflicto y Cohesión Social (COES), adjunct researcher at the 
Center for Climate and Resilience Research (CR2), and member of Colectivo de Estudios Políticos (CEPA). He holds a PhD in political science from Sciences Po and Universidad Católica de Chile. His research deals with the politics of the policy process, with a focus on business power and the policy outcomes of social mobilization, mostly in environmental issues.

Daniel E. Moreno Morales is a Bolivian social researcher and holds a $\mathrm{PhD}$ from Vanderbilt University (2008), a master's degree from the University of Pittsburgh (2005), both in political science, and a master's degree in sociology from Universidad Mayor de San Simon, Cochabamba, Bolivia. He is an expert in survey and public opinion research, having led some of the major international comparative survey projects in Bolivia. He is currently a senior researcher at Ciudadanía, Comunidad de Estudios Sociales y Acción Pública (www.ciudadaniabolivia.org) and CEO at the polling company DATACCION SRL (www.dataccion.com.bo). His research interests include citizenship, democratic legitimacy, ethnic identities, and survey methods.

Maritza Paredes holds a $\mathrm{PhD}$ in international development from Oxford University. Currently she is an associate professor at the Department of Social Sciences, Sociology Section, Pontificia Universidad Católica del Perú (PUCP).

Violeta Rabi Blondel is a sociologist from the Universidad de Chile. She holds a postgraduate certificate in sustainability from the Universidad de Chile and a master of science in environment from the University of Melbourne, Australia. Currently, she works as the Senior Researcher of the Sustainability Area at the think tank Espacio Público. Her research areas focus on socio-ecological transformations, environmental institutions and policy, environmental democracy, social movements, and models of development.

Bettina Schorr holds a $\mathrm{PhD}$ in political science from the Department of International Relations and Foreign Policy Analysis of the Universität zu Köln, Germany and a magister degree in political science from the same university. Her research interests include social inequalities and sustainable development, institutional change, and dynamics of social conflicts (contentious politics). Currently, she is a lecturer at the Institute for Latin American Studies at Freie Universität Berlin, Germany, and the program director of trAndeS-Postgraduate Program on Social Inequalities and Sustainable Development in the Andean Region. 
$\because$ Taylor \& Francis

Taylor \& Francis Group

http://taylorandfrancis.com 


\section{Part 1}

\section{Introduction}


$\because$ Taylor \& Francis

Taylor \& Francis Group

http://taylorandfrancis.com 


\title{
1 A curse over the Andes?
}

\author{
The resource curse approach \\ and institutional change in the \\ Andean region
}

Bettina Schorr and Gerardo Damonte

\section{Introduction}

Endowed with vast and precious reserves, the countries located along the Andean arch have built their economies around the extraction and exportation of natural resources, mostly hydrocarbons and minerals. In many countries, the significance of the extractive sector has always been high. It increased to historically unique levels with the latest global commodity boom in the years 2003 to 2013 that was fueled by Chinese demand and drove prices sky-high for Andean natural resources of the global markets (Hanni et al., 2018; Bebbington, 2012).

This latest boom has profoundly changed the socio-economic landscape of the region. Given the extraordinary influx of rents and capital, all countries achieved notable improvements regarding the reduction of poverty (Cord et al., 2015; Gasparini \& Cruces, 2013; Stampini et al., 2016). Income inequality, which until then had ranked amongst the highest in the world, decreased sharply (López-Calva \& Lustig, 2010; CEPAL, 2019), motivating scholars to speak of a historical moment of equality for Latin America (Fritz \& Lavinas, 2015).

Notwithstanding these notable improvements, scholarship concerned with the resource curse calls for caution when assessing socio-economic and political dynamics in so-called resource economies that depend on the extraction and export of natural resources. In particular, research has shown that in absence of a robust regulatory framework, resource-rich economies will suffer from a series of political and economic pathologies that can erode short-term improvements stemming from windfalls during booms. The expressions of the resource curse may include economic instability and poverty, inflation, authoritarian rule, corruption, and civil strife, among others.

In fact, various studies have found the curse to be raging in the Andean region by causing financial mismanagement, poverty, and social inequalities (Carrillo Hoyos, 2019; Amézquita Zárate, 2014; Hinojosa, 2011; Perry \& Olivera, 2009; Viale et al., 2017) as well as problems arising from the lack of economic diversification (Ducoing et al., 2018; Tello, 2013; Caria, 2017; Viale, 2019; Barja Daza \& Zavaleta Castellón, 2016), even inside the extractive sector (Cisneros, this volume). In addition, several studies show environmental damages and social conflicts as consequences of the extractivist development 
models promoted in the region (Arellano-Yanguas, 2011; Bebbington \& Bury, 2013; Delamaza et al., 2017; Andrade \& Morales, 2007; Ponce \& McClintock, 2014). As a matter of fact, the environmental consequences and social conflicts provoked by resource extraction have been one of the main focal points of scholarship on the Andean countries during the latest boom.

On the other side of the coin, the recent boom also constituted a period of significant institutional change. In particular, positive trends regarding the decrease in poverty and inequality have been attributed partly to the implementation of new redistributive and social policies (Sánchez-Ancochea, 2019). Other institutional changes in the region include the implementation of powersharing institutions like political decentralization and new participatory institutions, new political transparency rules, and novel environmental legislation. All of these changes share the potential to jump-start important social and distributional consequences that are considered capable of leading the societies of the Andean countries towards more stable and peaceful livelihoods in a healthier natural environment. In other words, they hold the potential of avoiding or mitigating the resource curse.

Yet, research has concentrated on the different expressions of the curse and is largely silent on questions of institutional change and performance in resourcedependent states. For the Andean region, only a few studies have explored institutional dynamics during the latest boom period (Dargent, Orihuela, et al., 2017; Damonte et al., 2021; Bebbington, 2012; Orihuela, 2013; Haslam, 2016; Haslam \& Heidrich, 2018). These are single-country studies (Dargent, Orihuela, et al., 2017; Damonte et al., 2021), which concentrate on specific types of institutions (Haslam \& Heidrich, 2018), or focus on empirical developments in isolation without placing them in the context of broader conceptual or theoretical debates regarding institutional dynamics in resource economies (Damonte et al., 2021; Bebbington, 2012; but see Orihuela, 2013; Haslam, 2016; Haslam \& Heidrich, 2018). As a consequence, we still have only a limited understanding of precisely how institutional change capable of avoiding or mitigating the curse takes place, or the factors that affect the effective performance of such institutions.

This book steps into this gap. By drawing on the fertile grounds of the recent institutional developments in the Andes, it addresses the subject of institutional change and performance under the potentially adverse conditions of resource economies and weak public capacities. Studying several countries of the Andean region, the chapters in this book focus on the causes and actors of institutional change and assess the performance of a variety of new institutions adopted to mitigate the pathologies associated with the resource curse. Taken together, the chapters paint a complex scenario in which institutional change was promoted by a variety of actors following different incentives and using different methods. Likewise, they reveal that institutional performance depends on an entire array of factors, both related and unrelated to the specific dynamics of resource economies. 
In the remainder of this introduction, we briefly review the resource curse literature by putting emphasis on the ways in which resource dependency affects institutions in particular. Building on the limited previous scholarship (Orihuela, 2013; Haslam, 2016; Haslam \& Heidrich, 2018), we criticize this perspective for forecasting doom for a wide range of (otherwise dissimilar) countries, namely those that lack a robust institutional framework when the extractive sector starts to boom. We then discuss the literature concerned with institutional analysis, which has only rarely been connected to the discussion on the resource curse (but see Dargent, Orihuela, et al., 2017). In order to build up a comprehensive perspective on the agents that can promote change and the instruments they use, we add to the literature of institutional analysis insights from policy studies and the contentious politics/social movements literature. On this basis, we elaborate a four-field matrix of agents of institutional change. Each field will be discussed briefly with empirical evidence stemming from an external literature review and the new contributions of the chapters of this book. In the subsequent section, we explore institutional performance in the region stressing those factors that constrain the new institutions from reaching their full effect. We finish by clarifying our central concepts-resource curse, institutions, institutional change, and performance-by presenting the objectives of the book, its organization, as well as short summaries of each of its chapters.

\section{The resource curse: maladies and remedies}

What has become to be known as the resource curse rests on the paradoxical observation that resource-rich countries face a very high risk of suffering a whole series of economic and political pathologies: They tend to be cursed by their riches, which seals their fate as chronic economic and political underperformers (Auty, 1993; Sachs \& Warner, 1999). The maladies coming along with the curse can be manifold and include macro-economic effects such as the deterioration of the terms of trade, the balance of payment crises (also known as the Dutch disease), or the erosion of economic sectors others than the extractive one. Resource wealth tends to be associated with unpopular growth, enduring poverty, and social inequalities (Orihuela, 2013). It has also been shown to motivate corruption and patronage (Mahdavy, 1970; Crystal, 1990; Ross, 2001; Caselli \& Michaels, 2013; Andersen \& Aslaksen, 2013; Zhu \& Wu, 2014) as well as conflict and crime, to perpetuate unqualified or autocratic rulers in power (Cuaresma et al., 2010; Andersen \& Aslaksen, 2013; Brunnschweiler \& Bulte, 2008; Brollo et al., 2013) and to reduce democratic quality (Paler, 2013; Luong \& Weinthal, 2009). Recent scholarship has stressed the environmental and health damages resulting from the extensive extraction of natural resources in the territories where it takes place (Gilberthorpe \& Papyrakis, 2015). In a similar manner, coining the concept of a subnational resource curse, scholars have called attention to the fact that the resource curse tends to be uneven and affects 
particularly those subnational units where the resources are found (Paler, 2011; Manzano \& Gutiérrez, 2019).

The resource curse is believed to be rooted in specific state-society relations that lack a robust fiscal pact (Moore, 2004; Karl, 2007): Since rulers do not have to rely on tax payers among the general public in order to obtain money, they have no incentive to act in a transparent and accountable way. Two mechanisms mediate between resource wealth and the different manifestations of the curse: rent-seeking and political myopia. Rent-seeking is motivated by the extensive gains the extractive sector generates. It denotes a behavior of public officials who engage in politics or work in the public sector because it ensures them access to these rents. As a consequence, wealth stemming from the resource sector ends up concentrated in the hands of a few corporate and political actors, with the latter using rents as patronage to stay in power (Robinson et al., 2006).

Political myopia in the context of resource-based economies refers to an observed short-term bias towards the political support of the extractive sector. Governments and decision-makers focus on the sector while simultaneously ignoring its risks, such as the world markets' inherent volatility or the environmental costs it entails (Brollo et al., 2013; Karl, 1997; Kolstad \& Wiig, 2009; Stevens \& Dietsche, 2008). Political myopia prevents economic diversification by impeding investments in other areas that would guarantee a lesser dependence on the resource sector (Karl, 1997; Shafer, 1994). Also, it restricts regulation, which would imply a reduction of the profits of the sector or limit its activities. Rent-seeking and political myopia can be reinforced by private actors as well as by the state. Business has been found to lobby for the perpetuation of the political focus on the sector or bribe politicians into supporting it because it serves their own particular interests (Karl, 2007; Kaup, 2010).

The curse is not an inevitable fate, though, as can be seen in countries like Norway, Canada, or Australia. It rather depends upon the institutional setting in place and its ability to constrain politicians' behavior (Boschini et al., 2007; Karl, 1997; Kolstad \& Wiig, 2009; Lederman \& Maloney, 2009; Mehlum et al., 2006; Robinson et al., 2006; Ross, 1999, 2015; Sarmidi et al., 2014; Tornell \& Lane, 1999). Therefore, some authors argue it should rather be interpreted as an institutions curse (Menaldo, 2016).

As a policy implication of this observation, the literature has established a firm institutions matter argument that underscores the importance of high-quality institutions to avoid the curse (Mehlum et al., 2006). While generally accepted, at least two aspects of this argument remain unresolved: First, there is no consensus as to which institutions matter when, how, and where (Orihuela, 2018). Research has initially focused on economic institutions (such as stabilization funds and other countercyclical measures) able to counter the negative effects of the inherent volatility of the sector and institutions promoting economic diversification (Kurtz \& Brooks, 2011; Gylfason, 2011; Torvik, 2011; Sugawara, 2014).

More recently, the perspective broadened beyond the economic realm and focused on the good governance of the resource sector (Thorp et al., 2012; 
Bebbington et al., 2018). While good governance is often used in an unspecific way, it generally refers to sectoral regulation, fiscal and administrative regulation, distributive and redistributive instruments, transparency and accountability rules, as well as social and environmental provisions (e.g. Cameron \& Stanley, 2017). Systematizing the various streams in this literature, Orihuela (2018) identifies six governance challenges resource-dependent states are facing: macroeconomic management, the local and sectoral economy, the sustainability of economic growth, democracy, environmental justice and community inclusion, and peace. Each of these comes with specific development problems such as the balance of payment crisis, environmental burdens, political anomia, and the growth of an anti-politics machine. In order to tame the curse, a comprehensive institutional framework must address these six government challenges simultaneously.

The second unresolved problem is related. It raises the question as to how these institutions that matter and are good can come into being and perform effectively. This question is of particular importance for those resource-rich non-western, non-industrialized countries lacking robust statehood and democratic quality and featuring high levels of poverty and social inequality - a group that includes the majority of countries labeled as developing. Under these adverse conditions that foster all sorts of deficiencies, the prospects for avoiding the curse are discouraging. Will these countries ever be able to escape it?

While the resource curse theory understands institutions as a remedy for the curse, it is surprisingly silent on how these institutions can be built or changed (but see Haslam, 2016; Orihuela, 2013, 2018; Dietsche, 2007). As Haslam (2016, p. 1146) states, the resource curse theory is "principally a theory of decline and has paid relatively little attention to how countries may turn back from the rentier to the developmental state". The principal policy implication of the literature is almost tantamount to a conviction: If states have good institutions, they will be able to turn their "rents into riches" (Barma et al., 2012). If not, they will succumb to the curse (Menaldo, 2016).

What the resource curse perspective has failed to consider is that institutional change under conditions of resource dependence is occurring, as discussed earlier for the latest commodity boom in the Andean region. In fact, if the curse is a function of the behavior of decision-makers, it cannot be excluded a priori that they can make good choices, even under potentially bad conditions (Dietsche, 2007; see also Grindle, 2004). Once the possibility of agency is granted, the important question is under which conditions decision-makers may decide to build institutions for good governance and under which conditions these may work towards mitigating or avoiding the curse and generating inclusive and sustainable development. Moreover, in the context of formal democratic rule and a globalized world, other actors may also be able to promote institutional change. Yet, given the resource curse theory's focus on the maladies and not the remedies, our understanding of how institutions emerge and function under the adverse conditions of poverty, inequality, limited state capacity, and resource dependence is still only preliminary. 


\section{Institutions and institutional change}

The subject of institutional emergence and change is treated primarily in an academic field referred to as institutional analysis, which is composed of three major schools: New Institutionalism Economics, Sociological Institutionalism, and Historical Institutionalism (Campbell, 2004; Hall \& Taylor, 1996). While these schools differ regarding their analytical foci and epistemological assumptions, institutions are generally understood, in the classical words of Douglass North (1990, p. 3), as the "rules of the game in a society. More formally, as the humanly devised constraints that shape human interaction". They consist of "formal and informal rules and the monitoring and sanctioning mechanisms that cause actors to comply with these rules" (Ibid.). As the definition indicates, institutions can be differentiated into formal and informal ones (Helmke \& Levitsky, 2006; Tsai, 2016; Fligstein, 1996). The former are understood in terms of written rules that are made, transmitted, and reproduced through channels widely thought to be official. In contrast, informal institutions represent "socially shared rules, usually unwritten, that are created, communicated and enforced outside of officially sanctioned channels" (Helmke \& Levitsky, 2004, p. 727). The legitimacy of these informal institutions is based on references to socially acceptable ways of doing things, claims to tradition, identity, rights, or existing or previous authority relations (Hall et al., 2014). Informal institutions exist everywhere, also in the context of formal organizations (such as state agencies, corporations, or social organizations). In some cases, actors may combine formal and informal institutional practices, developing hybrid institutional regimes (Sindzingre, 2006; Damonte, 2018, 2021).

Scholars across the different institutional schools understand institutions as products of specific power relations with - at least in the case of most economic and political institutions - significant distributional effects (Streeck \& Thelen, 2005b; Mahoney \& Thelen, 2010). Institutions are viewed as being sustained and imposed by those holding sufficient power to do so (Hall, 1986; Knight, 1992; Mahoney, 2010; Acemoglu \& Robinson, 2006). A similar perspective is offered by the political settlement approach within development studies, which focuses on how the informal constellation of power in any given polity affects the opportunities for institutional change (Khan, 2018; Di John \& Putzel, 2009). Conceiving of institutions as results of power relations has implications for their lifespan: They persist as long as those in power approve of them or are able to sustain them.

Treating power as a constitutive element of institutional emergence implies no judgment about their quality: they still can be good or bad. To grasp the effects of institutions on collective well-being, Acemoglu and Robinson (2012) differentiate between extractive and inclusive political and economic institutions. Extractive institutions are rules that allow a small group of individuals to exploit the resources (including human resources) of the polity in which they are acting. They can be found in many former colonies (Ibid.). Inclusive institutions allow for a wide participation of different social groups and individuals in the 
process of governing, attenuating, or preventing the exploitation of resources or people (or, for that matter, the resource curse). In a similar manner, the aforementioned settlement approach distinguishes between inclusive settlements willing to widely distribute development benefits and exclusive settlements where only elites capture the benefits (rents, money from donor corporation, etc.; see also Moore, 2004).

The literature discusses two pathways of institutional change: revolutionary or sudden change versus evolutionary or incremental change. The first presupposes a punctuated equilibrium model, in which large phases of institutional stability (thought of as an equilibrium) sustained by a specific coalition give way to comparatively shorter phases of sudden change (Mahoney, 2000). Such change happens in the context of critical junctures, understood as periods of contingency during which the usual constraints on action are lifted or eased. As a consequence, old institutions can be unmade and new ones emerge (Capoccia \& Kelemen, 2007).

Institutional change can also be endogenous, slow and, often not so visible (Mahoney \& Thelen, 2010; Streeck \& Thelen, 2005a; Campbell, 2004). It has been argued that the very nature of institutions as products of power relations renders them prone to slow and gradual change from within, not just during extraordinary critical junctures. For instance, coalitions sustaining specific institutions may change their interest due to developments in the external context and, consequently, change the rules. Also, ruling coalitions are often composed of different groups with heterogeneous goals (Palier, 2005; Schickler, 2001). Changes in the balance of power within these groups may lead to institutional change. In addition, institutions are generally open to ambiguity and interpretation (Sheingate, 2010; Thelen, 2004). One and the same rule may be interpreted and enforced in very different ways depending on the interests and resources of the sustaining coalition or the organization in charge of enforcement. Finally, compliance with institutions is itself always variable. In principle, all institutions can be politically contested or driven to exhaustion by non-compliance or gradual defection.

While in some instances institutional change can be driven by competition (Campbell, 2010), institutional models may also diffuse and reproduce from one organizational setting to another (DiMaggio \& Powell, 1983; Hannan \& Freeman, 1989). Referred to as institutional isomorphism, this latter mechanism takes place not only on the national level but also globally. Isomorphism can take the form of mimicry (when one party imitates institutions seen in other places that are perceived as attractive). Particularly in cases of global norm diffusion, coercion (when one party is able to force the other party to accept change) or norm-abidance (when different parties across the globe abide by international conventions and their institutional consequences) are driving forces. Indeed, many lower- and middle-income countries have adopted institutional reforms in response to pressures (or incentives) set by international organizations (e.g. World Bank, International Monetary Fund, or OECD; see Dobbin et al., 2007) or by complying with international conventions (such as UN conventions, see 
later). The theory of change implied is that these powerful international actors are able to set economic or status incentives which can pressure national elites or governments into institutional change. Furthermore, not responding to such international pressure could also generate undesired domestic situations such as social protests or electoral losses, which can motivate institutional change.

While gradual change is promoted by power holders or enforcers (political and administrative), the idea of sudden institutional change within critical junctures recognizes that actors outside of ruling coalitions may challenge the institutional status quo. As a matter of fact, especially in countries characterized by closed political systems, weak state structures, and large power asymmetries, pressures by non-elite challengers on those in power may be essential for changing the balance of power sustaining specific institutions or institutional arrangements (Lipsky, 1968; Piven \& Cloward, 1979). In this line, the Advocacy Coalition Framework (ACF) focuses on how policy change is produced in interactions among different advocacy coalitions (Sabatier \& Weible, 2007). Policies understood as the formal or informal guidelines for decision-making are not necessarily the same as institutions. However, the two may overlap when policies stipulate rules for specific actors and are enforced or publicly or by means of social pressure (Streeck \& Thelen, 2005b). Advocacy coalitions include generally a wide spectrum of different private and public actors, form on the basis of shared beliefs, and are characterized by a non-trivial degree of coordinated activity over time. Connecting to institutional analysis, it has been argued that coalitions are most likely to achieve policy change during critical junctures when the distribution of resources (money, public opinion, information, leadership, etc.) shifts so that coalitions are empowered to impose their demands for change (Sabatier \& Weible, 2007).

Policy or institutional change may also be promoted outside of established formal channels, in the streets, by means of social mobilization. For such a contentious challenge to emerge, political entrepreneurs have to accumulate resources, mobilize people with convincing interpretative frames, and seize on opportunities when they open up (Tilly \& Tarrow, 2007). Political outcomes caused by such mobilized actors vary from agenda setting to actual institutional reform (Kolb, 2007). Regarding the latter, research has stressed that mobilizers must win allies from within the system (Andrews, 2001) or else force decisionmakers into change. In this way, massive social mobilizations may create the critical junctures during which institutional change becomes possible (Kurzman, 1996).

Social activism to promote institutional or policy change is not limited to national boundaries. Globalization has set the conditions for transnational activism in which groups or individuals from different countries join to promote a common cause on a global level (Olesen, 2010; Tarrow, 2005; Della Porta \& Tarrow, 2004). These transnational movements or advocacy coalitions may address governments, international organizations, or private actors such as companies. Often, international conventions are promoted by international organizations and transnational advocacy groups alike. Transnational activism and advocacy 
matter for domestic institutional change as they provide material resources, knowledge and information, legitimacy, and network contacts to domestic challengers (Keck \& Sikkink, 1998). They may also trigger a boomerang-effect by convincing a powerful outsider (another government or an international organization) to pressure governments to give in to domestic demands (Ibid.).

\section{Institutional change in the Andean resource economies}

As explained in the previous section, institutional emergence and change can be gradual through different mechanisms or sudden in the context of critical junctures. Different actors may promote institutional change who can be classified according to two dimensions: the political level where they operate (domestic - international/global) and according to their power position, i.e. if they form part of the ruling coalition or if they are powerful international organizations or if they are external challengers to the institutional status quo. This classification can be translated into a matrix (Figure 2.1a) that differentiates into four types of agents of institutional change: domestic power holders/ ruling coalitions, domestic challengers, global powerful organizations, and transnational challengers.

These four types must be understood as ideal-types. In real life, it is often precisely the interaction of these actors that ultimately produces (or hinders) institutional change. In the following, we use this matrix as an organization principle for the review of research on dynamics of institutional change (including the chapters of this book) in the Andean resource economies. We focus on inclusive institutions intended to mitigate or avoid the different manifestations of the resource curse both during the latest resource boom as well as during previous episodes. The review is not meant to be exhaustive, but it aims at providing an overview of what empirical research has found so far.

Table 1.1 Four agents of institutional change

\begin{tabular}{|c|c|c|c|}
\hline & & \multicolumn{2}{|l|}{ Level } \\
\hline & & Domestic & International/global \\
\hline \multirow{8}{*}{ 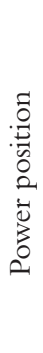 } & Powerholders & local and national & \multirow{8}{*}{$\begin{array}{l}\text { international } \\
\text { organizations; bi- } \\
\text { and multinational } \\
\text { donor cooperation, } \\
\text { transnational } \\
\text { corporations } \\
\text { transnational } \\
\text { advocacy networks; } \\
\text { transnational activism }\end{array}$} \\
\hline & & governments and elite & \\
\hline & & settlements/coalitions; & \\
\hline & & business actors & \\
\hline & & & \\
\hline & Challengers & social movements; & \\
\hline & & domestic advocacy & \\
\hline & & $\begin{array}{l}\text { coalitions; community } \\
\text { actors/activists }\end{array}$ & \\
\hline
\end{tabular}

Source: Own elaboration 


\section{Ruling coalitions as agents of institutional change: governments, elites, business}

Institutional change, promoted by domestic powerholders and ruling coalitions, may be the most obvious type since these agents hold the power to impose change. As mentioned earlier, these coalitions may integrate different groups with different power differentials, and institutional change may reflect a reconfiguration within an existing elite settlement. Historically, such new elite settlements or reconfigurations within these have profoundly shaped the governance of the extractive industries and the distribution of its rents (for the case of Bolivia and Peru, see Bebbington et al., 2018). Also during the latest commodity boom, governments have implemented institutional reforms to regulate the extractive sector and improve the distribution of its gains (rents) as well as its costs (particularly environmental costs). For instance, fiscal reforms have been implemented across the region to enhance the public share of rents produced by the natural resource sector (Jiménez, this volume). In many countries, the rents of the sector were decentralized, benefitting in the first place the producing regions (Jiménez, this volume; Arellano-Yanguas, 2011; Arellano-Yanguas \& Acosta, 2014). Likewise, innovative social policies such as conditional cash transfer programs fueled by the rents of the economic boom have been introduced all over the region (Evia, this volume; Osorio, 2020; Borges, 2018; Hunter, 2021). Governments have also adopted new environmental legislation to reduce the ecological damages caused by the extractive sector (Bornschlegl and Paredes \& Figueroa, this volume; see also Orihuela \& Paredes, 2017; Madariaga, 2018; Orihuela et al., 2021; Bravo, 2021; Orihuela \& Granados, 2021).

Diverse incentives that drove governors or ruling coalitions to adopt institutional change included domestic social pressure and conflicts (see later; Bebbington, 2012; Arellano-Yanguas, 2011; Humphreys Bebbington \& Bebbington, 2010) or the desire to prevent them (Arellano-Yanguas, 2011), the existence of high profits that motivated governments to capture a greater share of the rents and distribute them more widely (Haslam \& Heidrich, 2018), and ideological convictions (Ibid.; Kaup, 2010).

Policy diffusion took place through external coercion by international actors and by norm-abidance to international conventions (see later). Likewise, diffusion by mimicry has been identified as a driving force behind change. For instance, beginning in the early 2000s the already-mentioned conditional cash transfer programs diffused throughout the region because governments imitated the successful Brazilian example (Borges, 2018; Osorio, 2020). More generically and sustained by a mix of diffusion mechanisms, the diffusion of the green state in Latin America, i.e. the establishment of state institutions in charge of environmental protection, has been explored by Orihuela (2014). However, as the author makes clear, such processes of diffusion never suppose the establishment of global institutional blueprints. They are always subjected to processes of local adaption, which causes variation in their outcomes and effectiveness. 
Institutional change towards mitigating the resource curse has also been the result of mutual learning processes among elites. In Chile, learning processes among the national elites led to the establishment of Sovereign Wealth Funds that allowed for a more cautious macro-economic management of the Chilean resource economy (Orihuela, 2013). In fact, cooperation and learning among elites has always been a factor in taming the resource curse in Chile, at least in some of its expressions. Already in the 19th century, Chilean elites agreed to invest the rents from the resource sector into building a strong and capable state apparatus that formed the fundament for subsequent institutional change aiming at mitigating the curse (Kurtz, 2013).

Although not necessarily a direct part of the government or ruling coalition, business actors generally also command power. In fact, the resource curse literature attributes business a causal role in the production of the curse by profiting from rent-seeking activities and resisting change (Karl, 1997; Kaup, 2010; Durand, 2019). Business elites are without any doubt powerful political players in Latin America (Clark \& North, 2018). However, despite the assumptions of the resource curse literature, Haslam (2016) stresses the role of strong business actors in driving institutional change to tame the resource curse. Comparing Chile and Argentina, he found that in Chile a strong business community was able to pressure the state into a shift from a rent-seeking strategy to an entrepreneurial strategy. As a consequence, several expressions of the curse could be mitigated by promoting productive investments, joint ventures, and entrepreneurial learning. The author also shows that the support for institutional change was selective. In other cases, business remained passive vis-à-vis the rent-seeking activities of the state (e.g. within the Chilean National Mining Company ENAMI), which constrained institutional change in these sectors. In Argentina, quite to the contrary, weak business associations at the federal and provincial levels were unable to counter politicians' rent-seeking, thereby perpetuating the resource curse. A similar argument on the positive relationship between cohesive business networks and elites' willingness to support a fairer distribution of national resources is made by Cárdenas (2020). Saylor (2014), on the other hand, theorizes that the rents of the resource sector tend to be used in a productive way and to strengthen the state when exporter interests are represented in the respective ruling coalition (which he found to be the case in Chile and Argentina).

Last but not least, during the latest boom period in the Andes, companies have gradually intensified their community relations with the communities living near their projects, mostly in order to prevent or mitigate social resistance (Frederiksen, 2018). Scholars have begun to analyze these new practices and rules introduced by companies in the localities where they operate as part of their Corporate Social Responsibility (CSR) programs (Himley, 2012; Leiva, 2019; Haslam, 2021; Bebbington, 2010). They have focused on the consequences of these programs in terms of local development, social cohesion, and state-society relations. The findings of these studies are mixed: While some practices such as providing housing or public infrastructure or producing social 
capital may qualify as inclusive and able to counter the (local) curse (Cesar \& Jhony, 2020), others have been found to exacerbate local inequalities, legitimate ecological destruction, and promote tensions among community members (Gamu \& Dauvergne, 2018).

\section{International actors as agents of institutional change}

Powerful international actors, in particular bi- and multilateral donor cooperation, have also promoted institutional change in the Andean resource economies. Using different leverages, particularly financial ones and the assignment of symbolic capital for internationally approved good behavior (Larsen, 2016), international agents have achieved a lasting impact on the institutional arrangements capable of mitigating the resource curse in the Andean countries.

The influence of multilateral actors comprises a wide array of sectors and institutions. For instance, the United Nations have shaped many domestic environmental systems in the region on the basis of the UN Rio Convention adopted in 1992 during the Earth Summit in Rio de Janeiro (see Godfrid for Argentina and Rabi and Campos for Chile, this volume). Also, the UN declarations of Human Rights and Indigenous Rights were translated into the domestic law of several Andean countries. Likewise, the European Union has shaped institutional developments in the region, promoting amongst others environmental and labor regulation, especially as part of their free trade agreements (for instance with Colombia, Peru, and Chile).

International organizations such as the World Bank and the IMF ever since had an enormous impact on economic and fiscal reforms in the region, starting with the austerity measures applied in the 1980s. While in the past often criticized for promoting extractive institutions, during the recent boom period these organizations have also promoted institutional change with the potential to mitigate the resource curse, as several chapters in this volume show. For example, the World Bank conditioned a considerable credit to bolster the mining sector to the establishment of an environmental ministry in Peru (Paredes and Figueroa, this volume; Orihuela \& Paredes, 2017). Chile and Colombia (as actual members) and Peru (as an aspiring member) have set up new regulatory institutions in order to meet the membership requirements of the OECD. In Chile, the OECD required a public environmental system as a condition for the country to obtain full OECD membership (Maillet and Carrasco and Rabi and Campos, this volume). Also, several specific regulations, such as the carbon tax and measures against air pollution, were a direct result of OECD recommendations (Madariaga, 2018). Previous to that, anti-corruption and transparency legislation was adopted to fulfil OECD requirements. Peru and Colombia have to different degrees responded to OECD requirements: Colombia introduced major reforms in the labor sector and justice system, as well as regarding transparency and anti-corruption. Similarly, Peru has translated OECD standards regarding transparency in the public administration, anti-corruption, and environmental standards. As an example of the influence of a single bilateral 
donor, Godfrid (this volume) shows that in the Argentinian province of San Juan, Japanese cooperation was deeply involved in the establishment of new environmental rules.

Regarding transparency in the extractive sector, the transnational EITI framework has made some inroads in the region (Bebbington et al., 2016). As an initiative bringing together corporate, civil, and governmental actors, the Extractive Industries Transparency Initiative (EITI) was launched in 2007 on initiative of former British Prime Minister Tony Blair to promote standards for transparency and accountability in the management of revenues from natural resources. Countries commit to the EITI standard on a voluntary basis and become full members only following an independent certification of accounts that reconcile the figures that companies report having paid and government says it has received. Peru and Colombia are full EITI members and have adapted to the organizational standards. Ecuador and Argentina have solicited membership and are being evaluated against the EITI standards.

Often, several international actors have promoted the same institutions in the region. For instance, political and fiscal decentralization was a core subject of bi- and multilateral donors' influence during the 1990s and early 2000s (OECD, 2004). The diffusion of the green state as studied by Orihuela (2013) has been supported by different international actors. Several important concepts applied in the regulation of natural resources were promoted by bi- and multilateral donor cooperation. To name just a view out of many: The concept of Integrated Water Resources Management was promoted as particularly important for regions affected by mineral extraction and has been adopted in several national water sectors in the Andean region (Biswas et al., 2009). Concepts for land use planning aiming at the sustainable use of natural resources have been diffused by international organizations and NGOs throughout the region (Gustafsson et al., 2020). Finally, during years of new formats of citizen participation - in general to enhance the legitimacy and transparency of political decisions (Peruzzotti, 2012; McNulty, 2012; Leal, 2007) and in particular to improve resource governance and environment protection-have ranked high on the international agendas for the Andean countries and were introduced as new domestic rules in several target countries (Paredes \& Schorr, 2021).

\section{Domestic and transnational challengers as agents of change}

Domestic and transnational challengers promoting institutional change from the outside of the political establishment can take the form of advocacy coalitions or social movements and protest groups. During the last decade, academic interest in the dynamics of social conflicts motivated by extractive projects and politics has grown exponentially, although with a minor focus on the outcomes and legacies of these conflicts. In the first place, activism has been found to achieve the suspension of projects or to impose significant changes to their original design (Delamaza et al., 2017 for the case of Chile). In a few cases, researchers showed that social conflicts provoked institutional changes (Bebbington, 2012): 
In Peru (Arellano-Yanguas, 2011) and in Bolivia (Humphreys Bebbington \& Bebbington, 2010), social contention led to new laws regarding the distribution of revenues stemming from mining and hydrocarbons. Protest reclaimed new forms of citizen participation (for the case of Peru, see Paredes \& Schorr, 2021), including the legal regulation of consultation processes with indigenous communities (Flemmer, this volume). In Ecuador, social pressure managed to shape the new mining legislation that introduced inter alia the concept of no-go zones in forest reserves and near rivers (Moore \& Velásquez, 2011). In 2021, a popular referendum growing out of years of social activism vetoed mining activities in the Ecuadorian province of Azuay, one of Ecuador's new mining hotspots (Wingfield et al., 2021). The conflict in the Argentinean region of Esquel spurred seven out of 23 provinces to ratify a mining ban prohibiting open-pit mining activities in their territories (Walter \& Martinez-Alier, 2010). Furthermore, the adoption/refinement of a new environmental regulation in San Juan, Argentina can be attributed partly to social protests (Godfrid, this volume). In Chile and in Peru, advocacy coalitions managed to pressure legislators to adopt new regulations for political transparency (Schorr, this volume) and imposed environmental regulation with regard to the mining sector in the Ecuadorian Intag valley (Flora et al., 2006) and in Chile (Madariaga \& Allain, 2018).

As mentioned previously, institutions can be differentiated into formal and informal ones. Agents external to ruling coalitions have also influenced the establishment of informal institutions, both as organized and non-organized actors. For instance, mobilized groups introduced new forms of informal political institutions such as the popular referendums conducted in Argentina, Peru, and Colombia (Dietz, 2019; Walter \& Urkidi, 2017). Moreno (this volume) establishes a connection between the increasing perception of political corruption during the post-boom phase and the ways citizens in the Andean countries view democracy and participate in politics. He finds that the significantly increased perception of corruption correlates strongly with informal ways of engaging in politics, such as street mobilizations and activism in neighborhood associations. In contrast, formal participation, for instance in elections, is declining throughout the region, as is trust in democracy in general. Finally, locallevel actors can also achieve institutional change regarding the ways resources are governed, in case they are strong enough to negotiate with the state for the recognition of local informal rules. This can be observed in the informal mining sectors in Bolivia, where the mining cooperatives were important allies of the Morales government (Amengual \& Dargent, 2020), and in Peru, where informal miners mustered sufficient political strength (by means of social mobilizations as well as by forming coalitions) to prevent the state from imposing its institutional agenda in local resource governance (Damonte, 2018, this volume).

Traditionally, transnational advocacy has played a significant role in promoting environmental standards and human rights in Latin America (Keck \& Sikkink, 1998). Generally, the role of transnational advocacy is supportive, and, in fact, several of the domestic challenges mentioned earlier have benefitted from transnational advocacy. Flemmer (this volume), for instance, stresses the role of 
transnational advocacy in the promotion of prior consultation in particular and indigenous rights in general. During the latest boom, transnational advocacy was more involved in particular campaigns against certain projects or corporations. For instance, the social conflicts over the mining projects in Pascua Lama in Chile (Schorr, 2018; Urkidi, 2010), Tambogrande (Haarstad \& Fløysand, 2007) and Espinar (Paredes, 2016) in Peru, and Cotacachi in Ecuador (Kuecker, 2007) have involved global advocacy groups bringing together diverse national and global watchdog groups, NGOs, and international organizations to support local actors in their struggles against extractive projects promoted by states and corporations.

\section{From institutional adoption to institutional performance}

As laid out previously, institutional change promoted by different actors has been widespread in the Andean region during the latest boom period and before. However, as a large political science literature reminds us, the adoption of new rules does not automatically translate into the intended behavioral change (Pressman \& Wildavsky, 1984; Sabatier, 2005; Mazmanian \& Sabatier, 1983). It has been stated that particularly in Latin America the adoption of new or the transformation of existing formal rules is rather frequent (Brinks et al., $2019,2020)$. The problem is that for several reasons these institutions remain ineffective, which would translate in our case into them losing their potential to mitigate the resource curse. In this section, we discuss a series of factors that research has found to constrain the effectiveness of institutions. Our aim is to give an overview over those forces and dynamics critical for scholarly assessment of the performance of institutions intended to tame the curse in resourcedependent contexts, using examples from this volume.

One of the main causes constraining institutions' potential effect is the lack of political will to enforce effectively, which can reduce institutional change to an act of window dressing by governments (Ibid.). The literature argues that governments create such window dressing institutions as an answer to external pressures (social protests or international organizations) to demonstrate commitment, while de facto they have no intention to implement them. In some cases, lobbyism by business elites may further reduce the political will to enforce or contribute to keep it low (Durand, 2016).

Non-enforcement can be achieved in different ways. Governments may choose to simply ignore a rule while leaving it on the books. More sophistically, non-enforcement can be ensured by shaping enforcement agencies in a way that they are unable to implement the rules of the institution of which they are officially in charge. This can include denying the allocation of sufficient resources, professional staff, or authority necessary to act. Research on Latin America in general and the Andean region in particular has identified weak enforcers as a cause of institutional ineffectiveness in a wide array of cases, including new indigenous autonomies introduced in Bolivia (Tockman \& Cameron, 2014), utility regulation (Murillo, 2009), environmental institutions (Orihuela \& 
Paredes, 2017; Orihuela \& Granados, 2021; Orihuela et al., 2021), and political decentralization (Dickovick \& Eaton, 2013). In fact, in postulating politicians' tendency to rent-seeking and political myopia, the resource curse literature would lead us to expect that in cases where agents managed to impose regulatory institutions against the adverse dynamics triggered by resource dependence, the political will to enforce them effectively would be thin. This should be particularly true for those institutional changes promoted by international agents or by social pressure, a point indeed made by various chapters in this book (see the chapters by Flemmer, Godfrid, Paredes and Figueroa, Maillet and Carrasco).

On the other hand, states may enforce selectively following different logics, a phenomenon which has been shown to be particularly pronounced in unequal societies such as the Andean ones certainly are (Amengual \& Dargent, 2020). States may bring the rule of law to bear on poor people while desisting from enforcement in wealthier segments (Brinks, 2008; Méndez et al., 1999), they may ramp up enforcement in some regions and not in others (O'Donnell, 1993; Soifer, 2015), or they may enforce rules against political enemies while being forbearing with political allies or electoral constituencies (Holland, 2017). The latter has been found in the case of enforcement of different types of regulation in the small-scale mining sector in Bolivia: Given that the mining cooperatives were close allies of the Morales government, regulation was not enforced against them (Amengual \& Dargent, 2020). Likewise, companies have been shown to avoid the rigid enforcement of regulatory legislation in the environmental sector or regarding the transparency of their financial transactions because of their close relations with governments and politicians (Bull \& Aguilar-Støen, 2016).

The lack of effective implementation is not always a direct reflection of a lack of political will. Non-enforcement or selective enforcement may result from an actual lack of resources. This factor is of particular importance for resource economies. Given the inherent volatility of the global markets, resource economies tend to alternate between phases of growth (booms) and phases of bust in which the rents of the resource sector diminish. In times of decreasing global demand, public accounts shrink and with them the ability of states to enforce. In the Andes, the most recent bust cycle has led to a significant reduction in public budgets. As a consequence, public investments including social spending have dropped significantly (Jiménez and Evia, this volume). A particular harsh example for this dynamic is Bolivia, where social programs are directly tied to the existence of resource rents. The lack of resources provoked by the economic downturn has also affected enforcement in the environmental sector, as Bornschlegl and Godfrid (this volume) show for the cases of Ecuador and Argentina respectively.

Even if political will exists and a stable access to resources is guaranteed, effective implementation of institutions may still be hampered by a lack of professional capacity and the absence of skilled enforcers (Peters, 2018). In addition, organizations are not only a mere consequence of the institutions they are supposed to enforce; they also lead a life of their own (Dargent, Orihuela et al., 2017, p. 14). The management and administrative staff have a certain 
autonomy over the rules they are in charge of, which can affect the way implementation is carried out and hence the effectiveness of institutions (Mahoney \& Thelen, 2010). In Latin America in general and in the Andean countries in particular, bureaucratic capacity is low, which reduces the degree and quality of implementation (Polga-Hecimovich, 2019). This has also been shown for institutions capable of mitigating the resource curse. For instance, Orihuela et al. (2021) attribute the lack of enforcement in the Peruvian environmental sector to the absence of a professional bureaucracy. Likewise, Paredes and Figueroa (this volume) call attention to the fact that the lack of skilled and motivated staff is limiting the operation of the new Peruvian Environmental Ministry. They argue that notwithstanding formal institutional change, the actual practices of bureaucrats within the new organization have not changed. For this reason, the regulatory capacity of the ministry and its executive organs remains weak.

Another factor potentially reducing the effectiveness of institutions is their design. Design can, on purpose, produce insignificance and establish window dressing institutions (Brinks et al., 2020). In this volume, Rabi and Campos argue that the Environmental Courts in Chile correspond to such a pre-emptive design. They argue that the courts have been set up intentionally in a way that would not put too many constraints on the extractive sector. Maillet and Carrasco (this volume) state the same for the whole Chilean environmental system, to which the courts studied by Rabi and Campos belong. They argue that the Chilean environmental subsector is nested in a powerful extractivist economic system and too weak to actually constrain it effectively. As a consequence, both the number of the projects as well as the conflicts surrounding them have increased. Also, Paredes and Figueroa (this volume) mention the relative powerlessness of the Peruvian environmental ministry vis-à-vis the powerful economic ministry MEM. The institution of prior consultation of indigenous peoples can also be interpreted as flawed by design. It is non-binding, neither actor must stick to the agreements, monitoring mechanisms are absent, and communities do not have the possibility to reject the realization of the project in their territory (Flemmer, this volume; see also Torres Wong, 2018; SchillingVacaflor \& Flemmer, 2015; Falleti \& Riofrancos, 2018). Thus, the effects that prior consultation actually produces are insignificant or outright counterproductive because they often increase social conflict, both within communities as well as between communities, corporations, and the state (Schilling-Vacaflor \& Eichler, 2017).

As with ineffective enforcement, default by design is not always the product of a strategic political calculus. Specific design features may generate unanticipated effects that may distort the actual objective of an institution when it operates. Such unintended effects can be observed in the fiscal reforms implemented during the latest resource boom in the Andes. While holding the potential of a more equal distribution of the extractive sectors' rents, in almost all countries of the region the reformed fiscal systems have produced or reinforced territorial inequalities (Jiménez, this volume). Unintended effects may be particularly prominent in case of global norm diffusion, when governments 
import institutional models developed and applied in other contexts. This has been studied by Weyland (2006) who showed that neighboring governments borrowed the model of private contribution-based pension system implemented in Chile because they perceived it as successful. However, these utterly failed under the entirely different conditions of Bolivia and Peru. Imported institutions may also fail to generate social commitment, as Paredes and Figueroa (this volume) claim for the case of the Peruvian environmental agency OEFA. Because this agency was perceived as alien by local actors, it ended up being unable to articulate political or social support to defend the rules it is supposed to enforce.

Finally, the chances for effective implementation also depend on how-by design-infraction is charged. If sanctions are so minimal that they do not cause deterrence, actors may be willing to accept the costs the sanctions imply which ends up hollowing the effect of the institution (Brinks et al., 2020). Such nonpunitive sanctions are applied to supposedly halter deforestation in Argentina (Fernández \& Garay, 2020, Amengual \& Dargent, 2020). They also can be found in the case of the Peruvian mining sector, where fees for environmental misconduct are so low that companies tend to pay them instead of changing their behavior and protecting the environment. Likewise, companies in the Ecuadorian oil sector prefer to pay administrative fines instead of maintaining their pipelines and avoiding oil spillings (Bornschlegl, this volume).

The effective implementation of institutions does not only depend on state capacity and the political will to enforce them. It is also a function of the willingness of citizens to accept and comply with institutions (Amengual \& Dargent, 2020). As stated before, states may lack the resources and capacity to enforce. In the Andean countries even, their territorial outreach is constrained. In many parts of the vast territories in the Amazon lowlands and the Andean highlands, the state is not present at all and other actors impose social order (e.g. indigenous communities or criminal groups).

In light of the role of such powerful non-state actors, it has been argued that state capacity has to be understood as relational (Dargent, Feldmann et al., 2017). States may be too weak to enforce specific institutions against the will of strong social groups or populations. In this volume, Damonte analyzes how both informal miners in the Peruvian Amazon as well as agroexporters in the region of Ica have managed to resist the institutional agendas of the central state and imposed their own informal practices in the sectoral governance.

Resisting the implementation of state institutions may be reinforced by a lack of trust in the state or its enforcers. Social acceptability of an institution is highly dependent on citizens' trust in public institutions and the state in general. The opposite, mistrust in the state and its enforcers, impedes the effective enforcement of institutions. It can be assumed that this factor has a particular weight in the Andean countries, where social trust in the state ranges among the lowest in the region (Moreno, this volume). Confirming this point, Bornschlegl finds in her case study, on the implementation of the program of environmental reparation in the Ecuadorian Amazonas, that local peoples' mistrust in the state 
and in the programs' officials significantly complicated the implementation of the new environmental institutions.

\section{Organization of the book}

This book is concerned with institutional change that could mitigate or avoid the different expressions of the resource curse in the context of resource dependence, poverty, and weak state capacities. We understand institutions as those formal and informal rules structuring human behavior and the monitoring and sanctioning mechanisms that cause actors to comply with these rules. Institutional change refers to the emergence of new rules or the qualitative transformation of existing ones so that their effect is enhanced.

Empirically, we focus on institutional developments in the Andean countries during the latest resource boom and the first post-boom years (2004-2014). Economically, these countries rely heavily on their extractive sectors, while state capacity in the region tends to be low (with the exception of Chile; see Soifer, 2015) and poverty, as well as social inequality, is high.

The chapters of this book focus on inclusive regulatory institutions in those governance sectors where the resource curse can unfold. They identify the agents and forces driving institutional change and explore the performance of these new institutions. In particular, the chapters study redistributive institutions, rules that ensure political transparency, participation and democratic governance in general, and environmental protection rules. We move beyond the economic institutions in our discussion because these have long been the focus of resource curse scholarship.

The book pursues two objectives: First, it delivers sound empirical evidence on institutional change and performance in the Andean countries before and during the latest boom period as well as the first post-boom years. Since the chapters are written from different disciplinary perspectives, they provide an abundant panorama of cases and approaches by using different qualitative and quantitative methods. Extending the period under analysis into the post-boom years further allows us to explore whether economic cycles affect the dynamics of institutional change and performance.

Second, the volume contributes to the theoretical development of the widely discussed resource curse approach by adding insights into the conditions that support or hinder institutional development in settings potentially affected by the curse. The chapters discuss different factors promoting change and affecting institutional performance. Moreover, in the concluding section, we elaborate an interdisciplinary research agenda on institutional change in resource-dependent contexts. This agenda is based on the analytical insights provided by the different chapters and binds them together in order to orient future research on the subject.

The book is organized into three sections: After this introduction, the second section contains 12 empirical studies that explore institutional change and performance in different Andean countries. We summarize each of these chapters briefly. 
The second section is opened by Jiménez's analysis of the fiscal reforms introduced in several Andean countries during the latest boom period. In particular, he examines the impact these reforms had on the public accounts, on the fiscal space, and on regional inequality. The chapter reveals that significant reforms have been undertaken in almost all countries of the region. As one effect, public accounts registered important increases that, amongst others, allowed for the implementation of new redistributive policies. However, the author also identifies two shortcomings of these reforms: First, fiscal resources stemming from the natural resource sector depend on the extreme volatility of the global markets. Once the boom period had receded, the sector's rents decreased dramatically, and with them the public accounts. Second, the new spending rules reinforced territorial inequalities in a region already hit by some of the highest regional disparities in the world.

Focusing on Bolivia as a single case study, Evia explores the social policy innovations adopted between 2003-2014. He states that these innovations were possible due to the reorganization of the hydrocarbons sector in the 1990s that paved the way for the unprecedented influx of rents during the latest economic boom period. These rents then allowed the government of Evo Morales to set up a social protection floor based on a series of conditional cash transfer (CCT) programs, an institutional model that had diffused throughout the region motivated by the Brazilian example. These new CCT are widely considered to have contributed to the impressive reduction of poverty experienced in Bolivia during the last decade. However, Evia also finds that these new institutions are financially unsustainable: Since the CCT were designed to depend directly on the influx of rents and hence on global demand, the economic downturn of the post-boom has led to important adjustments in volume and coverage. As Jiménez before, the author shows that institutional change towards inclusive institutions was possible but flawed by design.

The next chapter by Cisneros observes institutional dynamics within the wider extractivist sector in Ecuador. Against the prediction of the extractivist imperative debate, which holds that the extractive sector, once established, will continuously expand, Cisneros shows that in Ecuador the political intention to establish a mining industry along the lines of the traditional oil sector has failed. While some authors point to social resistance as the driver behind this failure, Cisneros offers another explanation. He argues that social protest was an important force for keeping mining at bay, but equally important for the expansion of the sector to fail were the institutional path dependencies created by the long tradition of oil extraction in Ecuador. These ultimately prevented, what the author calls, an extractive diversification in Ecuador.

Damonte calls attention to dynamics of institution-building in extractivist countries on the subnational level. He explores two cases of institutional emergence within the governing regulation of the Peruvian extractive sector: water extraction in Ica, mostly by large companies, and gold mining in Madre de Dios, mostly by informal small-scale miners. The author finds that locally a hybrid governance model was established that combines informal with formal 
institutions. The cases show that institution-building initiated by the state in order to govern extractive activities in territories of weak state control is a function of the agency and political leverage of the state but also of other social actors involved.

Flemmer studies the introduction of the framework for prior consultation of indigenous people, as stipulated in the ILO Convention No. 169, as a means of reducing the social and environmental impacts of extractive projects. The chapter explains the adoption of this framework by all Andean countries as a case of global norm diffusion promoted by international organizations and transnational advocacy. Drawing on the case of Peru, Flemmer analyzes the implementation of prior consultation and identifies a series of pitfalls, amongst which the limitations of the legal texts and processes imposed by the state in cooperation with corporate actors are the most important ones. As in the case of social and fiscal policies, the Peruvian law of prior consultation is flawed by design. Contrarily to the case of social and fiscal policies studied by Jiménez and Evia, Flemmer argues that the framework was intentionally downsized to avoid indigenous communities having a real say over the realization of extractive projects in their territories.

Using public opinion data for several Andean countries, Moreno traces in his chapter the evolution of the perception of corruption and explores the effects of citizens' perception of corruption on the quality of democracy. The author finds that the perception of corruption increased sharply as resources started to run short, i.e. when the boom subsided. In line with the resource curse literature, he confirms with statistical data that the perception of corruption indeed seems to have a detrimental effect on the support for democracy, affecting both trust in elections and satisfaction with how the political system is working in the country. Likewise, individual experience with corruption in the Andean countries shapes new informal institutions by increasing the chances that a person participates in extra-institutional political activities, such as street manifestations, and autonomous community-based activities. Like Damonte, Moreno calls attention to the effects that dynamics related to the resource sector can have on local informal practices.

In the next chapter, Schorr explores the contentious political processes to impose more effective political transparency rules in Chile and Peru. She argues that in both countries the same mechanism of change was at play, involving a combination of pressure from the inside of governmental institutions as well as from the outside: A strategic coalition among presidents and civil society actors was able to build circumstances in which delegates could not afford to vote against the reform proposals. However, the comparison between the political processes in Chile and Peru also leads the author to qualify the institutions matter argument of the resource curse literature. The analysis identifies the importance of the quality of the institutional fundament in place. In other words, resource economies can only be governed in a good way when the very political fundament of the polity in question - the grounds on which those institutions that matter have to be negotiated-is of a good quality. 


\section{Bettina Schorr and Gerardo Damonte}

Maillet and Carrasco analyze Chile's environmental system, which was established in response to requirements formulated by the OECD as a condition to obtain full membership. Chile's environmental system thus constitutes a type of global isomorphism and an example of the diffusion of the green state in the region. The authors argue that the environmental legislation adopted in 2010 is only apparent change. Factually, it does little to prevent environmental damage caused by the extractive industries because the institutional changes in the environmental subsystem are nested in a largely unchanged extractive regime. As a consequence, the overall regulatory impact of the new environmental institutions is low as documented in the increase of investments in the extractive sector as well as the growth of social conflicts around extractive projects.

The next chapter by Rabi and Campos connects to the previous chapter by exploring in detail the Environmental Courts (EC) in Chile established in 2012 as part of the new environmental system. The authors argue that policy-makers designed the EC with very limited authority in order to prevent them from inhibiting the activities of the extractive sector. Institutional barriers include the exclusion of individuals as claimants and limiting its authority to revising decisions issued by other state institutions. Moreover, analyzing the cases, claimants, and judgments the courts had issued until 2017, the chapter finds that environmental courts are used mainly by companies who contest decisions made by other state agencies against their projects, such as sanctions imposed by the Superintendence of the Environment. In contrast, communities not only are underrepresented as claimants, but also lose their cases in a greater proportion than the companies running the projects. The analysis of the actual operation of the EC, thus, shows that not only design matters and the behavior of officials, but also how social actors make use of institutions.

Paredes and Figueroa discuss the establishment of the Environmental Ministry in Peru. As the environmental framework in Chile, this new public institution was established in a top-down fashion based on international models promoted by the World Bank. It constitutes thus a case of institutional isomorphism. Moreover, the World Bank pressured the Peruvian governments to adopt the new institution by tying it to a considerable credit. Specifically, Paredes and Figueroa argue that the new environmental institution was imposed without dismantling old and ineffective institutional practices and established identities related to the bureaucratic culture in Peru. Thus, despite the new formal institutional setup, actual bureaucratic operating practices did not change, which significantly weakened the regulatory capacities of the new institution from the very beginning. Furthermore, perceived as something alien and imposed from external actors, the new environmental agency was unable to articulate political or social support to defend the new rules.

Bornschlegl examines the institutionalization of the concept of integral reparations, included in 2008 in the new Ecuadorian constitution, and institutionalized as a proper state program: the program of Social and Environmental Reparation (PRAS) at the Ecuadorian Ministry of Environment. The author identifies the most critical constraints it encountered. She finds that the enforcement of 
the reparación integral was severely constrained by three lacking elements: a lack of funding, a lack of executive power, and a lack of trust on part of the local communities. As a consequence of these shortcomings, the new legislation was unable to reach its stated aims.

Godfrid addresses changes to the environmental monitoring institutions for the mining sector in the province of San Juan, Argentina during the period 1993 to 2020. She argues that the main factors that have motivated the institutional transformation of environmental monitoring of mining were coercion by international agencies (1993-2002), socio-environmental conflicts (2003-2014), and mining accidents (2015-2019). These external factors prompted the creation of regulations and bureaucratic departments for the environmental oversight of mining that did not previously exist at the subnational level. However, the political decision by the authorities in San Juan to prioritize mining led to a reactive institutional change that limited the capacity for environmental oversight as well as the means to respond to public demands for transparency and participation. The analysis shows that the political dimension is key to understanding the reactive institutional change process and in particular the weakness of the environmental oversight institutions for mining in San Juan.

The book closes with the third section that contains the concluding chapter. In this conclusion, we summarize the main contributions of the volume and sketch a research agenda for future investigations into institutional dynamics in contexts characterized by resource dependence and weak state capacities. As the book in general, this research agenda is thought of as a first step. We hope that it will contribute to advance research in the important questions the book is raising in order to enhance our knowledge on how actors may master adverse situations by building and implementing effective regulatory and inclusive institutions.

\section{References}

Acemoglu, D., \& Robinson, J. A. (2006). Economic origins of dictatorship and democracy. Cambridge University Press.

Acemoglu, D., \& Robinson, J. A. (2012). Why nations fail: The origins of power, prosperity, and poverty. Crown Business.

Amengual, M., \& Dargent, E. (2020). The social determinants of enforcement. In D. M. Brinks, S. Levitsky, \& M. V. Murillo (Eds.), The politics of institutional weakness in Latin America (pp. 161-182). Cambridge University Press. https://doi.org/10.1017/9781108776608.007 Amézquita Zárate, P. (2014). Minería y petróleo en Colombia: Maldición interna de los recursos. Económicas CUC, 35(1), 45-59. https://revistascientificas.cuc.edu.co/ economicascuc/article/view/217

Andersen, J. J., \& Aslaksen, S. (2013). Oil and political survival. Journal of Development Economics, 100(1), 89-106. https://doi.org/10.1016/j.jdeveco.2012.08.008

Andrade, S., \& Morales, J. (2007). The role of the natural resource curse in preventing development in politically unstable countries: Case studies of Angola and Bolivia. Development Research Working Paper Series No. 11. Institute for Advanced Development Studies. 
Andrews, K. T. (2001). Social movements and policy implementation: The Mississippi civil rights movement and the war on poverty, 1965 to 1971. American Sociological Review, 66(1), 71-95. https://doi.org/10.2307/2657394

Arellano-Yanguas, J. (2011). Aggravating the resource curse: Decentralization, mining and conflict in Peru. Journal of Development Studies, 47(4), 617-638. https://doi. org $/ 10.1080 / 00220381003706478$

Arellano-Yanguas, J., \& Acosta, A. M. (2014). Extractive industries, revenue allocation and local politics. UNRISD Working Paper No. 4. UNRISD. www.econstor.eu/bitstream/10419/148753/1/861317270.pdf

Auty, R. M. (1993). Sustaining development in mineral economies: The resource curse thesis. Routledge.

Barja Daza, G., \& Zavaleta Castellón, D. (2016). Disminución de precios de commodities en un ambiente de enfermedad holandesa y bendición/maldición de los recursos naturales. Revista Latinoamericana de Desarrollo Económico, 25, 7-40.

Barma, N. H., Kaiser, K., Le, T. M., \& Vinuela, L. (2012). Rents to riches? The political economy of natural resource-led development. World Bank. https://openknowledge.worldbank.org/ handle/10986/2381

Bebbington, A. (2010). Extractive industries and stunted states: Conflict, responsibility and institutional change in the Andes. In K. Ravi Raman \& R. D. Lipschutz (Eds.), Corporate social responsibility: Comparative critiques (pp. 97-115). Palgrave Macmillan.

Bebbington, A. (Ed.). (2012). Social conflict, economic development and extractive industries. Routledge.

Bebbington, A., Abdulai, A.-G., Bebbington, D. H., Hinfelaar, M., \& Sanborn, C. A. (2018). Governing extractive industries: Politics, histories, ideas. Oxford University Press.

Bebbington, A., Arond, E., \& Dammert, J. L. (2016). Scalar politics and transnational governance innovations: A political settlements lens on the extractive industries transparency initiative in the Andes. Global Development Institute Working Paper Series. The University of Manchester.

Bebbington, A., \& Bury, J. (2013). Subterranean struggles: New dynamics of mining, oil, and gas in Latin America. University of Texas Press.

Biswas, A. K., Braga, B. P., Tortajada, C., \& Palermo, M. (2009). Integrated water resources management in Latin America. Taylor and Francis. http://gbv.eblib.com/patron/FullRecord. aspx?p=1395763

Borges, F. A. (2018). Neoliberalism with a human face? Ideology and the diffusion of Latin America's conditional cash transfers. Comparative Politics, 50(2), 147-167. www.jstor.org/ stable/26532676

Boschini, A. D., Pettersson, J., \& Roine, J. (2007). Resource curse or not: A question of appropriability. Scandinavian Journal of Economics, 109(3), 593-617. https://doi. org/10.1111/j.1467-9442.2007.00509.x

Bravo, M. (2021). Trayectorias de la gobernanza de los recursos naturales en la Selva Central del Perú. In G. Damonte, B. Göbel, M. Paredes, B. Schorr, \& G. Castillo (Eds.), ¿Una oportunidad perdida? Boom extractivo y cambios institucionales en el Perú (pp. 189-222). Fondo Editorial, Pontificia Universidad Católica del Perú; Ibero-Amerikanisches Institut.

Brinks, D. M. (2008). The judicial response to police killings in Latin America. Cambridge University Press. https://doi.org/10.1017/CBO9780511551130

Brinks, D. M., Levitsky, S., \& Murillo, M. V. (Eds.). (2019). Understanding institutional weakness. Cambridge University Press. https://doi.org/10.1017/9781108772211

Brinks, D. M., Levitsky, S., \& Murillo, M. V. (Eds.). (2020). The politics of institutional weakness in Latin America. Cambridge University Press. https://doi.org/10.1017/9781108776608

Brollo, F., Nannicini, T., Perotti, R., \& Tabellini, G. (2013). The political resource curse. American Economic Review, 103(5), 1759-1796. https://doi.org/10.1257/aer.103.5.1759 
Brunnschweiler, C., \& Bulte, E. (2008). The resource curse revisited and revised: A tale of paradoxes and red herrings. Journal of Environmental Economics and Management, 55(3), $248-264$.

Bull, B., \& Aguilar-Støen, M. (2016). Changing elites, institutions and environmental governance. In F. de Castro, B. Hogenboom, \& M. Baud (Eds.), Environmental governance in Latin America (pp. 137-163). Palgrave Macmillan. https://doi.org/10.1007/978-1-137-50572-9_6

Cameron, P. D., \& Stanley, M. C. (2017). Oil, gas, and mining: A sourcebook for understanding the extractive industries. World Bank. https://doi.org/10.1596/978-0-8213-9658-2

Campbell, J. L. (2004). Institutional change and globalization. Princeton University Press. https:// doi.org/10.2307/j.ctv131bw68

Campbell, J. L. (2010). Institutional reproduction and change. In G. Morgan, J. L. Campbell, C. Crouch, O. K. Pedersen, \& R. Whitley (Eds.), The Oxford handbook of comparative institutional analysis. Oxford University Press.

Capoccia, G., \& Kelemen, R. D. (2007). The study of critical junctures: Theory, narrative, and counterfactuals in historical institutionalism. World Politics, 59(3), 341-369. https:// doi.org/10.1017/S0043887100020852

Cárdenas, J. (2020). Exploring the relationship between business elite networks and redistributive social policies in Latin American countries. Sustainability, 12(1), 13. https://doi. org/10.3390/su12010013

Caria, S. (2017). El petróleo en Ecuador, 2000-2015 ¿Maldición, bendición o simple recurso? Revista Iberoamericana de Estudios de Desarrollo, 6(2), 124-147. https://doi. org/10.26754/ojs_ried/ijds.248

Carrillo Hoyos, S. (2019). Extractive industry revenues and the subnational resource curse: The case of the Peruvian Andes. The Extractive Industries and Society, 6(4), 1134-1142. https://doi.org/10.1016/j.exis.2019.06.001

Caselli, F., \& Michaels, G. (2013). Do oil windfalls improve living standards? Evidence from Brazil. American Economic Journal: Applied Economics, 5(1), 208-238. https://doi.org/10.1257/app.5.1.208

CEPAL. (2019). Panorama social de América Latina 2018. Comisión Económica para América Latina y el Caribe (CEPAL). http://hdl.handle.net/11362/44395

Cesar, S., \& Jhony, O. (2020). Corporate social responsibility supports the construction of a strong social capital in the mining context: Evidence from Peru. Journal of Cleaner Production, 267, 122162. https://doi.org/10.1016/j.jclepro.2020.122162

Clark, T., \& North, L. (2018). Dominant elites in Latin America: From neo-liberalism to the 'pink tide'. Latin American political economy. Springer International Publishing. https://doi. org/10.1007/978-3-319-53255-4

Cord, L., Genoni, M. E., \& Rodriguez Castelan, C. (2015). Shared prosperity and poverty eradication in Latin America and the Caribbean. World Bank. http://hdl.handle.net/10986/21751

Crystal, J. (1990). Oil and politics in the Gulf. Cambridge University Press. https://doi.org/10.1017/ CBO9780511558818

Cuaresma, J. C., Oberhofer, H., \& Raschky, P. A. (2010). Oil and the duration of dictatorships. Public Choice, 148(3/4), 505-530. www.jstor.org/stable/41483710

Damonte, G. (2018). Mining formalization at the margins of the state: Small-scale miners and state governance in the Peruvian Amazon. Development and Change, 49(5), 1314-1335. https://doi.org/10.1111/dech.12414

Damonte, G. (2021). Limited state governance and institutional hybridization in alluvial ASM in Peru. Resources Policy, 72, 102118. https://doi.org/10.1016/j.resourpol.2021.102118

Damonte, G., Göbel, B., Paredes, M., Schorr, B., \& Castillo, G. (Eds.). (2021). ¿Una oportunidad perdida? Boom extractivo y cambios institucionales en el Perú. Fondo Editorial, Pontificia Universidad Católica del Perú; Ibero-Amerikanisches Institut. 
Dargent, E., Feldmann, A. E., \& Luna, J. P. (2017). Greater State capacity, lesser stateness: Lessons from the Peruvian commodity boom. Politics E Society, 45(1), 3-34. https://doi. org/10.1177/0032329216683164

Dargent, E., Orihuela, J. C., Paredes, M., \& Ulfe, M. E. (Eds.). (2017). Latin American political economy. Resource booms and institutional pathways: The case of the extractive industry in Peru. Palgrave Macmillan.

Delamaza, G., Maillet, A., \& Martínez Neira, C. (2017). Socio-territorial conflicts in Chile: Configuration and politicization (2005-2014). European Review of Latin American and Caribbean Studies, 104, 23-46. https://doi.org/10.18352/erlacs.10173

Della Porta, D., \& Tarrow, S. G. (2004). Transnational protest and global activism people, passions, and power. Rowman \& Littlefield.

Dickovick, J. T., \& Eaton, K. H. (2013). Latin America's resurgent centre: National government strategies after decentralization. Journal of Development Studies, 49(11), 1453-1466. https://doi.org/10.1080/00220388.2013.797073

Dietsche, E. (2007). Why the quality of institutions is not a cure for the "resource curse". The Journal of Energy and Development, 32(2), 262-282. www.jstor.org/stable/24813112

Dietz, K. (2019). Direct democracy in mining conflicts in Latin America: Mobilising against the La Colosa project in Colombia. Canadian Journal of Development, 40(2), 145-162. https://doi.org/10.1080/02255189.2018.1467830

Di John, J., \& Putzel, J. (2009). Political settlements. University of Birmingham. https://gsdrc. org/wp-content/uploads/2015/06/EIRS7.pdf

DiMaggio, P. J., \& Powell, W. W. (1983). The iron cage revisited: Institutional isomorphism and collective rationality in organizational fields. American Sociological Review, 48(2), 147-160. https://doi.org/10.2307/2095101

Dobbin, F., Simmons, B., \& Garrett, G. (2007). The global diffusion of public policies: Social construction, coercion, competition, or learning? Annual Review of Sociology, 33(1), 449-472. https://doi.org/10.1146/annurev.soc.33.090106.142507

Ducoing, C., Peres-Cajías, J., Badia-Miró, M., Bergquist, A.-K., Contreras, C., Ranestad, K., \& Torregrosa, S. (2018). Natural resources curse in the long run? Bolivia, Chile and Peru in the Nordic countries' mirror. Sustainability, 10(4), 965. https://doi.org/10.3390/ su10040965

Durand, F. (2016). Cuando el poder extractivo captura el estado: Lobbies, puertas giratorias y paquetazo ambiental en Perú. OXFAM.

Durand, F. (2019). La captura corporativa del estado en América Latina. trAndeS Working Paper Series No. 8. Lateinamerika-Institut, Freie Universität Berlin.

Falleti, T. G., \& Riofrancos, T. N. (2018). Endogenous participation: Strengthening prior consultation in extractive economies. World Politics, 70(1), 86-121. https://doi.org/10.1017/ S004388711700020X

Fernández, B., \& Garay, C. (2020). A multilevel approach to enforcement: Forest protection in the Argentine Chaco. In D. M. Brinks, S. Levitsky, \& M. V. Murillo (Eds.), The politics of institutional weakness in Latin America (pp. 183-207). Cambridge University Press.

Fligstein, N. (1996). Markets as politics: A political-cultural approach to market institutions. American Sociological Review, 61(4), 656-673. https://doi.org/10.2307/2096398

Flora, J. L., Flora, C. B., Campana, F., García Bravo, M., \& Fernández-Baca, E. (2006). Social capital and advocacy coalitions: Examples of environmental issues from Ecuador. In R. E. Rhoades (Ed.), Development with identity: Community, culture and sustainability in the Andes (pp. 287-297). CABI. https://doi.org/10.1079/9780851999494.0287

Frederiksen, T. (2018). Corporate social responsibility, risk and development in the mining industry. Resources Policy, 59, 495-505. https://doi.org/10.1016/j.resourpol.2018.09.004 
Fritz, B., \& Lavinas, L. (Eds.). (2015). A moment of equality for Latin America? Challenges for redistribution. Ashgate.

Gamu, J. K., \& Dauvergne, P. (2018). The slow violence of corporate social responsibility: The case of mining in Peru. Third World Quarterly, 39(5), 959-975. https://doi.org/10.1 080/01436597.2018.1432349

Gasparini, L., \& Cruces, G. (2013). Poverty and inequality in Latin America: A story of two decades. Journal of International Affairs, 66(2), 51-63. www.jstor.org/stable/24388285

Gilberthorpe, E., \& Papyrakis, E. (2015). The extractive industries and development: The resource curse at the micro, meso and macro levels. The Extractive Industries and Society, 2(2), 381-390. https://doi.org/10.1016/j.exis.2015.02.008

Grindle, M. S. (2004). Despite the odds: The contentious politics of education reform. Princeton University Press. www.jstor.org/stable/j.ctv36zq8d

Gustafsson, M.-T., Merino, R., \& Scurrah, M. (2020). Domestication of international norms for sustainable resource governance: Elite capture in Peru. Environmental Policy and Governance, 30(5), 227-238. https://doi.org/10.1002/eet.1904

Gylfason, T. (2011). Natural resource endowment: A mixed blessing. In R. Arezki, T. Gylfason, \& A. N. Sy (Eds.), Beyond the curse: Policies to harness the power of natural resource (pp. 7-34). IMF.

Haarstad, H., \& Fløysand, A. (2007). Globalization and the power of rescaled narratives: A case of opposition to mining in Tambogrande, Peru. Political Geography, 26(3), 289-308. https://doi.org/10.1016/j.polgeo.2006.10.014

Hall, K., Cleaver, F., Franks, T., \& Maganga, F. (2014). Capturing critical institutionalism: A synthesis of key themes and debates. European Journal of Development Research, 26, 71-86. http://doi.org/10.1057/ejdr.2013.48

Hall, P. A. (1986). Governing the economy: The politics of state intervention in Britain and France. Europe and the international order. Oxford University Press. www.loc.gov/catdir/enhancements/fy0603/86008654-d.html

Hall, P. A., \& Taylor, R. C. R. (1996). Political science and the three new institutionalisms. Political Studies, 44(5), 936-957. https://doi.org/10.1111/j.1467-9248.1996.tb00343.x

Hannan, M. T., \& Freeman, J. (1989). Organizational ecology. Harvard University Press.

Hanni, M., Jiménez, J. P., \& Ruelas, I. (2018). Regímenes fiscales vinculados a los recursos naturales no renovables en la región y su relación con el ciclo de precios: Evolución reciente y desafíos pendientes. Serie Macroeconomia de Desarrollo No. 195. CEPAL. https://repositorio. cepal.org/bitstream/handle/11362/44239/S1800993_es.pdf?sequence=1\&isAllowed=y

Haslam, P. (2016). Overcoming the resource curse: Reform and the rentier state in Chile and Argentina, 1973-2000. Development and Change, 47(5), 1146-1170. https://doi. org/10.1111/dech.12259

Haslam, P. (2021). The micro-politics of corporate responsibility: How companies shape protest in communities affected by mining. World Development, 139, 105322. https://doi. org/10.1016/j.worlddev.2020.105322

Haslam, P., \& Heidrich, P. (2018). The political economy of natural resources and development: From neoliberalism to resource nationalism. Taylor and Francis. http://gbv.eblib.com/patron/ FullRecord.aspx?p=4391725

Helmke, G., \& Levitsky, S. (2004). Informal institutions and comparative politics: A research agenda. Perspectives on Politics, 2(4), 725-740. www.jstor.org/stable/3688540

Helmke, G., \& Levitsky, S. (Eds.). (2006). Informal institutions and democracy: Lessons from Latin America. Johns Hopkins University Press.

Himley, M. (2012). Regularizing extraction in Andean Peru: Mining and social mobilization in an age of corporate social responsibility. Antipode, 45(2), 394-416. https://doi. org/10.1111/j.1467-8330.2012.01001.x 
Hinojosa, L. (2011). Riqueza mineral y pobreza en los Andes. The European Journal of Development Research, 23(3), 488-504. https://EconPapers.repec.org/RePEc:pal:eurjdr:v:23:y :2011:i:3:p:488-504

Holland, A. C. (2017). Forbearance as redistribution: The politics of informal welfare in Latin America. Cambridge University Press. https://doi.org/10.1017/9781316795613

Humphreys Bebbington, D., \& Bebbington, A. (2010). Anatomy of a regional conflict: Tarija and resource grievances in Morales's Bolivia. Latin American Perspectives, 37(4), 140-160. https://doi.org/10.1177/0094582X10372503

Hunter, W. (2021). Diffusion dynamics. In D. Kapiszewski, S. Levitsky, \& D. J. Yashar (Eds.), The inclusionary turn in Latin American democracies (pp. 93-116). Cambridge University Press. https://doi.org/10.1017/9781108895835.004

Karl, T. L. (1997). The paradox of plenty: Oil booms and petro-states. University of California Press. http://hdl.handle.net/2027/heb.31620.0001.001

Karl, T. L. (2007). Ensuring fairness: The case for a transparent fiscal social contract. In M. Humphreys, J. Sachs, \& J. E. Stiglitz (Eds.), Initiative for policy dialogue at Columbia. Escaping the resource curse. Columbia University Press.

Kaup, B. Z. (2010). A neoliberal nationalization? Latin American Perspectives, 37(3), 123-138. https://doi.org/10.1177/0094582X10366534

Keck, M. E., \& Sikkink, K. (1998). Activists beyond borders: Advocacy networks in international politics. Cornell University Press. www.jstor.org/stable/10.7591/j.ctt5hh13f

Khan, M. H. (2018). Political settlements and the analysis of institutions. African Affairs, 117(469), 636-655. https://doi.org/10.1093/afraf/adx044

Knight, J. (1992). Institutions and social conflict. Cambridge University Press. https://doi. org/10.1017/CBO9780511528170

Kolb, F. (2007). Protest and opportunities: The political outcomes of social movements. Campus.

Kolstad, I., \& Wiig, A. (2009). It's the rents, stupid! The political economy of the resource curse. Energy Policy, 37(12), 5317-5325. https://doi.org/10.1016/j.enpol.2009.07.055

Kuecker, G. D. (2007). Fighting for the forests: Grassroots resistance to mining in northern Ecuador. Latin American Perspectives, 34(2), 94-107. www.jstor.org/stable/27648012

Kurtz, M. J. (2013). Latin American state-building in comparative perspective. Cambridge University Press. https://doi.org/10.1017/CBO9781139019668

Kurtz, M. J., \& Brooks, S. M. (2011). Conditioning the "resource curse": Globalization, human capital, and growth in oil-rich nations. Comparative Political Studies, 44(6), 747770. https://doi.org/10.1177/0010414011401215

Kurzman, C. (1996). Structural opportunity and perceived opportunity in social-movement theory: The Iranian revolution of 1979. American Sociological Review, 61(1), 153-170. https://doi.org/10.2307/2096411

Larsen, P. B. (2016). The "new jungle law": Development, indigenous rights and ILO Convention 169 in Latin America. Revue Internationale de Politique de Développement, 7.1. https://doi.org/10.4000/poldev.2220

Leal, P. A. (2007). Participation: The ascendancy of a buzzword in the neo-liberal era. Development in Practice, 17(4/5), 539-548. www.jstor.org/stable/25548251

Lederman, D., \& Maloney, W. F. (2009). In search of the missing resource curse. Economía, 9(1), 1-56. https://doi.org/10.1353/eco.0.0012

Leiva, F. I. (2019). Economic elites and new strategies for extractivism in Chile. European Review of Latin American and Caribbean Studies, 108, 131-152. https://doi.org/10.32992/ erlacs. 10511

Lipsky, M. (1968). Protest as a political resource. American Political Science Review, 62(4), 1144-1158. https://doi.org/10.2307/1953909 
López-Calva, L. F., \& Lustig, N. (Eds.). (2010). Declining inequality in Latin America: A decade of progress? Brookings Institution Press. www.jstor.org/stable/10.7864/j.ctt6wpdkq

Luong, P. J., \& Weinthal, E. (2009). Oil is not a curse: Ownership structure and institutions in soviet successor States. Cambridge University Press. http://site.ebrary.com/lib/academiccompletetitles/home.action

Madariaga, A. (2018). From "green laggard" to regional leader: Explaining the recent development of environmental policy in Chile. Bulletin of Latin American Research, 38(4), 453-470. https://doi.org/10.1111/blar.12841

Madariaga, A., \& Allain, M. (2018). Contingent coalitions in environmental policymaking: How civil society organizations influenced the Chilean renewable energy boom. Policy Studies Journal, 48(3), 672-699. https://doi.org/10.1111/psj.12298

Mahdavy, H. (1970). The patterns and problems of economic development in rentier states: The case of Iran. In M. A. Cook (Ed.), Studies in the economic history of the Middle East: From the rise of Islam to the present day (pp. 428-467). Oxford University Press.

Mahoney, J. (2000). Path dependence in historical sociology. Theory and Society, 29(4), 507-548. www.jstor.org/stable/3108585

Mahoney, J. (2010). Colonialism and postcolonial development: Spanish America in comparative perspective. Cambridge University Press. www.h-net.org/reviews/showrev.php?id=33004

Mahoney, J., \& Thelen, K. A. (Eds.). (2010). Explaining institutional change: Ambiguity, agency, and power. Cambridge University Press.

Manzano, O., \& Gutiérrez, J. D. (2019). The subnational resource curse: Theory and evidence. The Extractive Industries and Society, 6(2), 261-266. https://doi.org/10.1016/j. exis.2019.03.010

Mazmanian, D. A., \& Sabatier, P. A. (1983). Implementation and public policy. Scott Foresman and Co.

McNulty, S. (2012). An unlikely success: Peru's top-down participatory budgeting experience. Journal of Public Deliberation, 8(2). https://doi.org/10.16997/jdd.146

Mehlum, H., Moene, K., \& Torvik, R. (2006). Institutions and the resource curse. The Economic Journal, 116(508), 1-20. https://doi.org/10.1111/j.1468-0297.2006.01045.x

Menaldo, V. (2016). The institutions curse. Cambridge University Press. https://doi. org/10.1017/CBO9781316481530

Méndez, J. E., O’Donnell, G. A., \& Pinheiro, P. S. (Eds.). (1999). The (un)rule of law and the underprivileged in Latin America. University of Notre Dame Press.

Moore, J., \& Velásquez, T. (2011). Sovereignty negotiated: Anti-mining movements, the state and multinational mining companies under Correa's '21st century socialism. In A. Bebbington (Ed.), Social conflict, economic development and the extractive industry: Evidence from South America. Taylor \& Francis.

Moore, M. (2004). Revenues, state formation, and the quality of governance in developing countries. International Political Science Review, 25(3), 297-319. https://doi. org/10.1177/0192512104043018

Murillo, M. V. (2009). Political competition, partisanship, and policy making in Latin American public utilities. Cambridge University Press. https://doi.org/10.1017/CBO9780511813092

North, D. C. (1990). Institutions, institutional change and economic performance. Cambridge University Press. https://doi.org/10.1017/CBO9780511808678

O'Donnell, G. (1993). On the State, democratization and some conceptual problems: A Latin American view with glances at some postcommunist countries. World Development, 21(8), 1355-1369. https://doi.org/10.1016/0305-750x(93)90048-e

OECD. (2004). Lessons learned on donor support to decentralization and local governance. OECD. www.oecd.org/dac/evaluation/30395116.pdf 


\section{Bettina Schorr and Gerardo Damonte}

Olesen, T. (Ed.). (2010). Rethinking globalizations. Routledge.

Orihuela, J. C. (2013). How do "Mineral-States" learn? Path-dependence, networks, and policy change in the development of economic institutions. World Development, 43, 138-148. https://doi.org/10.1016/j.worlddev.2012.10.004

Orihuela, J. C. (2014). Converging divergence: The diffusion of the green state in Latin America. Studies in Comparative International Development, 49(2), 242-265. https://doi. org/10.1007/s12116-013-9147-6

Orihuela, J. C. (2018). Institutions and place: Bringing context back into the study of the resource curse. Journal of Institutional Economics, 14(1), 157-180. https://doi.org/10.1017/ S1744137417000236

Orihuela, J. C., \& Granados, A. (2021). Institucionalidad ambiental minera: Entre el discurso legal y las prácticas de gobierno. In G. Damonte, B. Göbel, M. Paredes, B. Schorr, \& G. Castillo (Eds.), ¿Una oportunidad perdida? Boom extractivo y cambios institucionales en el Perú (pp. 157-188). Fondo Editorial, Pontificia Universidad Católica del Perú; Ibero-Amerikanisches Institut.

Orihuela, J. C., Mendieta, A., Pérez, C., \& Ramírez, T. (2021). From paper institutions to bureaucratic autonomy: Institutional change as a resource curse remedy. World Development, 143, 105463. https://doi.org/10.1016/j.worlddev.2021.105463

Orihuela, J. C., \& Paredes, M. (2017). Fragmented layering: Building a green state for mining in Peru. In E. Dargent, J. C. Orihuela, M. Paredes, \& M. E. Ulfe (Eds.), Resource booms and institutional pathways: The case of the extractive industry in Peru (pp. 97-117). Palgrave Macmillan.

Osorio, C. (2020). Conditional cash transfer programs in Ecuador and Chile. The role of policy diffusion. Palgrave Macmillan. https://doi.org/10.1007/978-3-030-51008-4

Paler, L. (2011). The subnational resource curse: Causes, consequences and prescriptions. Revenue Watch Institute. https://laurapaler.files.wordpress.com/2012/11/rwi_subnat_curse.pdf

Paler, L. (2013). Keeping the public purse: An experiment in windfalls, taxes, and the incentives to restrain government. American Political Science Review, 107(4), 706-725. https:// doi.org/10.1017/S0003055413000415

Palier, B. (2005). Ambiguous agreement, cumulative change: French social policy in the 1990s. In W. Streeck \& K. A. Thelen (Eds.), Beyond continuity: Institutional change in advanced political economies (pp. 127-144). Oxford University Press.

Paredes, M. (2016). The glocalization of mining conflict: Cases from Peru. The Extractive Industries and Society, 3(4), 1046-1057. https://doi.org/10.1016/j.exis.2016.08.007

Paredes, M., \& Schorr, B. (2021). Transformaciones institucionales ambiguas: La producción de mecanismos de participación y coerción para la gobernanza de las industrias extractivas. In G. Damonte, B. Göbel, M. Paredes, B. Schorr, \& G. Castillo (Eds.), ¿Una oportunidad perdida? boom extractivo y cambios institucionales en el Perú (pp. 97-128). Fondo Editorial, Pontificia Universidad Católica del Perú; Ibero-Amerikanisches Institut.

Perry, G., \& Olivera, M. (2009). El impacto del petróleo y la minería en el desarrollo regional y local en Colombia. CAF Documento de trabajo 2009/06. CAF. http://scioteca.caf.com/ handle/123456789/199

Peruzzotti, E. (2012). Broadening the notion of democratic accountability: Participatory innovation in Latin America. Polity, 44(4), 625-642. https://doi.org/10.1057/ pol.2012.20

Peters, B. G. (2018). The politics of bureaucracy: An introduction to comparative public administration (7th ed.). Taylor \& Francis.

Piven, F. F., \& Cloward, R. A. (1979). Poor people's movements: Why they succeed, how they fail. Vintage Books.

Polga-Hecimovich, J. (Ed.). (2019). Oxford research encyclopedia of politics. Oxford University Press. 
Ponce, A. F., \& McClintock, C. (2014). The explosive combination of inefficient local bureaucracies and mining production: Evidence from localized societal protests in Peru. Latin American Politics and Society, 56(3), 118-140. https://doi.org/10.1111/j.1548-2456.2014.00243.x

Pressman, J. L., \& Wildavsky, A. B. (1984). Implementation: How great expectations in Washington are dashed in Oakland (3rd ed.). University of California Press.

Robinson, J. A., Torvik, R., \& Verdier, T. (2006). Political foundations of the resource curse. Journal of Development Economics, 79(2), 447-468. https://doi.org/10.1016/j. jdeveco.2006.01.008

Ross, M. L. (1999). The political economy of the resource curse. World Policy, 51, 297-322.

Ross, M. L. (2001). Does oil hinder democracy? World Politics, 53(3), 325-361. www.jstor. org/stable/25054153

Ross, M. L. (2015). What have we learned about the resource curse? Annual Review of Political Science, 18(1), 239-259. https://doi.org/10.1146/annurev-polisci-052213-040359

Sabatier, P. A. (2005). From policy implementation to policy change: A personal odyssey. In P. Maassen, A. Amaral, A. Arimoto, N. Cloete, D. Dill, J. Enders, P. Gumport, M. Henkel, G. Jones, Å. Gornitzka, \& M. Kogan (Eds.), Higher education dynamics. Reform and change in higher education (pp. 17-34). Springer Netherlands. https://doi.org/10.1007/1-4020-3411-3_2

Sabatier, P. A., \& Weible, C. M. (2007). The advocacy coalition framework: Innovations and clarifications. In P. A. Sabatier (Ed.), Theories of the policy process. Westview Press.

Sachs, J., \& Warner, A. (1999). The big rush, natural resource booms and growth. Journal of Development Economics, 59(1), 43-76. https://doi.org/10.3386/w5398

Sánchez-Ancochea, D. (2019). The surprising reduction of inequality during a commodity boom: What do we learn from Latin America? Journal of Economic Policy Reform, 43(6), 1-24. https://doi.org/10.1080/17487870.2019.1628757

Sarmidi, T., Hook Law, S., \& Jafari, Y. (2014). Resource curse: New evidence on the role of institutions. International Economic Journal, 28(1), 191-206. https://doi.org/10.1080/1 0168737.2013.787110

Saylor, R. (2014). State building in boom times: Commodities and coalitions in Latin America and Africa. Oxford University Press.

Schickler, E. (2001). Disjointed pluralism: Institutional innovation and the development of the U.S. Congress. Princeton University Press. www.jstor.org/stable/j.ctt7rr34

Schilling-Vacaflor, A., \& Eichler, J. (2017). The shady side of consultation: Tactics of "divide and rule" in Bolivia's resource extraction. Development and Change, 48(6), 1439-1463.

Schilling-Vacaflor, A., \& Flemmer, R. (2015). Conflict transformation through prior consultation? Lessons from Peru. Journal of Latin American Studies, 47(4), 811-839. https:// doi.org/10.1017/S0022216X15000826

Schorr, B. (2018). Oportunidades desiguales: Empresas y estado en conflictos sobre la minería en Chile. Estudios Atacameños, 57, 239-255.

Shafer, D. M. (1994). Winners and losers: How sectors shape the developmental prospects of states. Cornell University Press. www.jstor.org/stable/10.7591/j.ctv2n7fn1

Sheingate, A. (2010). Rethinking rules: Creativity and constraint in the U.S. House of Representatives. In J. Mahoney \& K. A. Thelen (Eds.), Explaining institutional change: Ambiguity, agency, and power (pp. 168-203). Cambridge University Press.

Sindzingre, A. (2006). The relevance of the concepts of formality and informality: A theoretical appraisal. In B. Guha-Khasnobis, R. Kanbur, \& E. Ostrom (Eds.), Linking the formal and informal economy (pp. 58-73.). Oxford University Press.

Soifer, H. D. (2015). State building in Latin America. Cambridge University Press. https://doi. org/10.1017/CBO9781316257289 


\section{Bettina Schorr and Gerardo Damonte}

Stampini, M., Robles, M., Sáenz, M., Ibarrarán, P., \& Medellín, N. (2016). Poverty, vulnerability, and the middle class in Latin America. Latin American Economic Review, 25(1), 112. https://doi.org/10.1007/s40503-016-0034-1

Stevens, P., \& Dietsche, E. (2008). Resource curse: An analysis of causes, experiences and possible ways forward. Energy Policy, 36(1), 56-65. https://doi.org/10.1016/j. enpol.2007.10.003

Streeck, W., \& Thelen, K. A. (Eds.). (2005a). Beyond continuity: Institutional change in advanced political economies. Oxford University Press.

Streeck, W., \& Thelen, K. A. (2005b). Institutional change in advanced political economies. In W. Streeck \& K. A. Thelen (Eds.), Beyond continuity: Institutional change in advanced political economies (pp. 1-39). Oxford University Press.

Sugawara, N. (2014). From volatility to stability in expenditure: Stabilization funds in resource-rich countries. IMF Working Paper No. 43. IMF. www.imf.org/external/pubs/ $\mathrm{ft} / \mathrm{wp} / 2014 / \mathrm{wp} 1443 . \mathrm{pdf}$

Tarrow, S. G. (2005). The new transnational activism. Cambridge University Press.

Tello, M. D. (2013). ¿Podemos hablar de una maldición de los recursos naturales en el Perú? Economía y Sociedad, 84, 42-48.

Thelen, K. (2004). How institutions evolve: The political economy of skills in Germany, Britain, the United States, and Japan. Cambridge University Press. https://doi.org/10.1017/ CBO9780511790997

Thorp, R., Battistelli, S., Guichaoua, Y., Orihuela, J. C., \& Paredes, M. (2012). The developmental challenges of mining and oil: Lessons from Africa and Latin America. Palgrave Macmillan.

Tilly, C., \& Tarrow, S. G. (2007). Contentious politics. Paradigm.

Tockman, J., \& Cameron, J. (2014). Indigenous autonomy and the contradictions of plurinationalism in Bolivia. Latin American Politics and Society, 56(3), 46-69. www.jstor.org/ stable/43284913

Tornell, A., \& Lane, P. R. (1999). The voracity effect. American Economic Review, 89(1), 22-46. https://doi.org/10.1257/aer.89.1.22

Torres Wong, M. (2018). Natural resources, extraction and indigenous rights in Latin America: Exploring the boundaries of environmental and state-corporate crime in Bolivia, Peru, and Mexico. Routledge.

Torvik, R. (2011). The political economy of reform in resource-rich countries. In R. Arezki, T. Gylfason, \& S. Amadou (Eds.), Beyond the curse: Policies to harness the power of natural resources (pp. 237-256). IMF. www.elibrary.imf.org/view/books/071/118189781616351458-en/11818-9781616351458-en-book.xml

Tsai, K. S. (2016). Adaptive informal institutions. In O. Fioretos, T. G. Falleti, \& A. Sheingate (Eds.), The Oxford handbook of historical institutionalism. Oxford University Press.

Urkidi, L. (2010). A glocal environmental movement against gold mining: Pascua-Lama in Chile. Ecological Economics, 70(2), 219-227. https://EconPapers.repec.org/RePEc:eee:ec olec:v:70:y:2010:i:2:p:219-227

Viale, C. (2019). ¿Qué diversificación económica queremos en los países andinos? Análisis comparado de políticas de diversificación económica: Reflexiones y nuevas propuestas. NRGI. https:// resourcegovernance.org/analysis-tools/publications/que-diversificacion-economicaqueremos-en-los-paises-andinos-analisis

Viale, C., Monge, C., Ballon, E., \& Molina, R. (2017). Minería y marcos institucionales en la región andina. El súper ciclo y su legado, o las difíciles relaciones entre políticas de promoción de la inversión minero-hidrocarburifera y las reformas institucionales. NRGI-GIZ.

Walter, M., \& Martinez-Alier, J. (2010). How to be heard when nobody wants to listen: Community action against mining in Argentina. Canadian Journal of Development Studies, 30(1-2), 281-301. https://doi.org/10.1080/02255189.2010.9669292 
Walter, M., \& Urkidi, L. (2017). Community mining consultations in Latin America (20022012): The contested emergence of a hybrid institution for participation. Geoforum, 84, 265-279. https://doi.org/10.1016/j.geoforum.2015.09.007

Weyland, K. (2006). Bounded rationality and policy diffusion: Social sector reform in Latin America. Princeton University Press.

Wingfield, S., Martínez-Moscoso, A., Quiroga, D., \& Ochoa-Herrera, V. (2021). Challenges to water management in Ecuador: Legal authorization, quality parameters, and sociopolitical responses. Water, 13(8), 1017. https://doi.org/10.3390/w13081017

Zhu, J., \& Wu, Y. (2014). Who pays more “tributes” to the government? Sectoral corruption of China's private enterprises. Crime, Law and Social Change, 61(3), 309-333. https://doi. org/10.1007/s10611-013-9504-4 
$\because$ Taylor \& Francis

Taylor \& Francis Group

http://taylorandfrancis.com 
Part 2

Empirical studies 
$\because$ Taylor \& Francis

Taylor \& Francis Group

http://taylorandfrancis.com 


\title{
2 Fiscal reforms and institutional changes in the Andean region
}

\author{
Revenues volatility and unequal \\ distribution of regional income
}

\author{
Juan Pablo Jiménez $z^{1}$
}

\section{Introduction}

During the latest commodity boom (2003-2008), the fiscal authorities of the Andean countries introduced a series of reforms. These followed two objectives: to raise revenues by capturing the extraordinary rents of the sector that had increased significantly in that period due to the high prices of regional commodities on the world markets; and to distribute these revenues among the different levels of government, financing the recent decentralization initiatives in the region (Brosio \& Jiménez, 2012; Gómez Sabaíni et al., 2018). For the former, governments implemented different measures: new taxes were introduced, royalty schemes were strengthened, and taxes on extraordinary revenues were established. To distribute the revenues originating from the extractive industries, governments introduced schemes allowing most of the tax revenues to flow back into the producing regions, and also facilitating the process of decentralization of public expenditure responsibilities in these countries implemented in those years (Brosio \& Jiménez, 2012).

Starting in 2012, global prices for mineral and hydrocarbon products dropped dramatically. This new scenario not only meant a decline in the fiscal relevance of these revenues, but also reoriented government's objectives and led to a reprioritization of more sustainable investment and production levels in the sector. The fall of the fiscal revenues also had an important impact on budgets of subnational governments, reducing the capacity of the public sector to intervene in the economy.

The specialization on nonrenewable natural resources is the origin of the high territorial inequality of income in the region, both among and within countries. In the Andean region, the ratio between the regions with the highest and lowest per capita GDP generally exceeds 6:1, while in developed countries it is rarely more than 3:1 (Brosio et al., 2018; CEPAL, 2017; Muñoz et al., 2016). This structural high regional inequality of income is produced by several factors, but mostly by the geographic concentration of the production of nonrenewable natural resources.

The significantly unequal regional distribution of income translates into sharp fiscal disparities. This is the case for a tax base that is highly regionally 
concentrated such as the taxation on consumption (ingresos brutos in Argentina, selective taxes in Colombia); but is still more significant when the tax base is nonrenewable natural resources because their deposits are regionally very concentrated (Brosio et al., 2018; Muñoz et al., 2016).

In consequence, when fiscal resources are not allocated and distributed adequately, they tend to exacerbate the structural high regional inequality and other imbalances among jurisdictions in the same country. This emphasizes the importance of tax power and spending responsibility assignments, jointly with the design of equalization systems of the distribution of fiscal revenues from nonrenewable natural resources among the different levels of government (Brosio \& Jiménez, 2015).

In a context of the increasing decentralization of responsibilities from the central to subnational governments (Brosio \& Jiménez, 2012), the volatility of these fiscal revenues has also a significant impact on the fiscal capacities and causes territorial disparities.

The goal of this article is to review the fiscal reforms on the extractive sector carried out during the last boom phase and their impact on the public accounts, fiscal space, and regional inequality. It focuses on several countries of the Andean region (Argentina, Bolivia, Chile, Colombia, Ecuador, and Peru) for the period 1990-2016.

The chapter discusses the reforms on the taxation of natural resources and mechanisms for the allocation and distribution of these revenues as cases of institutional change in the Andean countries accomplished in recent years. It assesses their potential and limitations to improve some of the chronic curses of the region's fiscal policy: the inability to promote sustainable economic growth; the weakness to address the very unequal distribution of income, both personal and regional; the difficulties in implementing sustainable reforms that strengthen the public sector by increasing fiscal revenues and improving its distribution.

This article proceeds as follows: First, it describes the fiscal reforms and the instruments these use related to the exploitation of nonrenewable natural resources, for the appropriation, allocation, and distribution of tax revenues obtained. Second, it assesses the performance of these reforms in terms of their impact in tax revenues and fiscal accounts, at the level of the central governments and the subnational governments. At the subnational level, the institutions and their dynamics will be analyzed, with a focus on their relationship with the different tax capacities of the territories and the concentration of tax revenues from the exploitation of nonrenewable natural resources. In the final section, the chapter analyzes the characteristics resulting from the combination of productive specialization, legal framework and price cycle, the main challenges in the post-bonanza context, and some possible alternatives to confront them. It argues that in order to confront the challenges arising from the price decline of the post-boom period, the reforms need to pursue different objectives than those implemented in the boom period. They must both attend to 
the sustainability of the sector, in terms of production and investment, as well as compensate for the decrease in tax revenues, at different levels of government, and its territorial impact.

\section{Evolution of fiscal instruments, revenue collection, allocation, and distribution of nonrenewable natural resources}

\section{Revenue collection instruments and recent fiscal reforms in the region}

In the period under analysis, tax revenues from the exploitation of nonrenewable natural resources were an important source of public resources in the Andean countries, both for central and subnational governments, although they have recorded strong fluctuations.

Given the magnitude and persistence of the upward trend in the price cycle that began in 2003 and increased significantly the rents of the extractive sector, the producing and exporting countries in the region found sufficient space to introduce substantial reforms in tax regimes applied to the production of hydrocarbons and minerals. These reforms were adopted in all countries regardless of the political orientation of the government (Hanni et al., 2018).

\section{During the commodity boom}

In Latin American countries, the most direct way of appropriation of commodity rents and their subsequent transformation in fiscal resources has been, historically, by participation in exploitation, whether through state-owned enterprises or shareholding (Hanni et al., 2018). These companies are often subject to a special tax regime, which may consist of rent payments or fees, additional taxes for public companies, or indirect selective (excise) taxes on oil production.

During the commodity boom, the reforms accentuated the specialization of tax systems, especially in hydrocarbons and minerals in the region's producing countries. They increased state control over available resources, introduced new taxes, strengthened royalty schemes, and established taxes on extraordinary revenues. ${ }^{2}$

Between 2005 and 2012, the most important legal reforms to ensure public control of nonrenewable natural resources focused on the hydrocarbon sector (CEPAL, 2013). These measures among the selected countries included the nationalization of the sector through joint ventures in Venezuela (between 2005 and 2007); in Bolivia, the renegotiation of hydrocarbon contracts, the renationalization of the Huanuni tin mine (2006), and the nationalization of the Colquiri mine in Oruro (2012); the renegotiation of oil contracts in Ecuador (2010), where production-sharing contracts were changed to service contracts in which the state is the owner of all the crude oil extracted with the stipulation that the government would absorb $100 \%$ of possible increases in oil prices. 
Additionally, other governments strengthened state ownership mechanisms such as royalties, usually based on production, and specific taxes. This was especially important in the mining sector, where revenue generation through state participation in enterprises was relatively low in the past. Royalties and taxes have ensured a minimum payment for resources to national and subnational governments as a growing number of countries with a variety of political orientations introduced reforms in the systems of royalties. These include Bolivia (2005), Ecuador (2010), Colombia (2011), and Peru (2011). In addition, in Ecuador, the hydrocarbon law reform established the margin of sovereignty designed to guarantee the state minimum revenues of $25 \%$ of the gross production value in case of possible price decreases. ${ }^{3}$

Traditional income taxes with multiple tax rates and other special charges have been applied, often with progressive rates on public or private companies exploiting nonrenewable resources. This has been reinforced with the introduction of new collection instruments (as in the case of Bolivia and Chile) during the period between 2005 and 2012. For instance, in 2005 Bolivia introduced the direct tax on hydrocarbons (Impuesto Directo a los Hidrocarburos, IDH) which, in addition to royalties and shares of the treasury led to a $50 \%$ direct participation of the state in extractive revenues. Meanwhile, in 2006 Chile introduced the specific tax on mining activity, which was applied to a type of net income that included the financial costs of depreciation of capital goods and interest. This aimed at strengthening taxation on mining (complementing the corporate tax and the tax over remittances of profits abroad) while procuring not to discourage private investment. In Venezuela, tax rates on income from oil (50\%) were increased in 2006, and three new taxes were created: the oil extraction tax, the export registration tax, and the Special Contribution on Extraordinary Prices and Exorbitant Prices in the International Hydrocarbons Market. In 2011, Peru updated its mining laws and introduced profit-based rather than revenue-based royalties, introducing three profit-based taxes: a mining royalty (Law 29788), a special mining tax (Law 29790), and a special mining contribution (Law 29789), the latter being paid in addition to the mining royalty. This was designed with the objective to collect more taxes from the most profitable operations and to minimize the risks to the government's revenue stream through the commodity supercycle.

Moreover, given the high volatility of international prices of nonrenewable resources, several countries like Bolivia, Colombia, Ecuador, and Venezuela have also considered the implementation of taxes, duties, participations, or contributions linked to prices or extraordinary profits (windfall taxes). Although there is a wide heterogeneity in this area, all countries that introduced these types of fiscal instruments did it during the period of the price boom (20032008), clearly as a reaction to the enormous increase in profits associated with hydrocarbon and mineral sectors among the countries of the region.

As noted by Acquatella et al. (2013), in Latin America the advances in tax progressivity have been clearer and concrete in the oil sector than in the mining sector. For example, in the oil sector, production service contracts and risk 
service contracts are very common. They anticipate an increasing scale of state participation in the profits as the project reaches increasing rates of return. In contrast, the incorporation of such a concept in the tax treatment of the mining sector in the countries of the region remains in its infancy, since mining countries, as shown in Table 2.2, rely heavily on royalties and corporate income tax for revenue generation. Chile is to some extent the only exception.

\section{After the boom}

Since 2013, the prices of mining and hydrocarbon products have decreased strongly, as a result of a slowdown in growth and investment in China and structural changes in the supply of these products (such as the rise in hydrocarbon production driven by the application of fracking technology in the United States, see Hanni et al., 2018). This decrease has an important fiscal impact: it reduces fiscal revenues (Gómez Sabaíni et al., 2018).

The sharp drop in prices of these products in recent years meant not only a fall in the fiscal relevance of these revenues but also a reformulation of the objectives to be followed and the tools to be used. In this new context, governments started to prioritize not only the level of tax revenues but also their impact on the sustainability of investments and production in the sector (Hanni et al., 2018). In the post-boom, the reforms in the sector show a growing concern for stimulating investment and production and for private sector participation, in addition to the need to maintain the tax contribution of nonrenewable natural resources. Indeed, several countries in the region have enacted policy measures in recent years aimed at stimulating activity in the extractive sector while creating sectoral long-term investment and savings funds.

The latest changes in the extractive sector prioritize objectives such as the promotion of production and investment and the degree of flexibility through structural reforms. They aim at ensuring the participation of the private sector and the creation of programs and incentive schemes for production (for instance in Argentina and Bolivia).

In 2015, Bolivia approved the law for investment promotion in exploration and exploitation to promote investment in the sector. The production incentives included in the law are financed mainly through a new fund created by the same law, the promotion fund for investment in exploration and exploitation in hydrocarbons (Fondo de Promoción a la Inversión en Exploración $y$ Explotación Hidrocarburifera, FPIEEH), fed with $12 \%$ of the direct tax levy on hydrocarbons.

In the mining sector, the objectives of the reforms during this period reflect the concern to promote mining activity, especially in order to ensure a continuous flow of investment into the sector. In Ecuador, for example, a package of measures to promote the development of the mining sector was promulgated in 2013, which reformulated the application of the extraordinary income tax. The new tax will only apply once the concessionaire has recovered its investments. 


\section{Juan Pablo Jiménez}

\section{Volatility of the tax collection coming from the nonrenewable}

natural resources

The institutional reforms and innovations in the fiscal and tax framework previously analyzed, in addition to the evolution of international prices, meant a strong increase in tax revenues in the period 2003-2008, a subsequent deceleration, and a significant fall in recent years (2012-2016, see Figure 2.1b).

The inherent volatility of these revenues complicates fiscal policy management in nonrenewable natural resource-producing countries. This is especially true in countries where these revenues have had a high share of total revenue during the price-cycle boom period. As illustrated in Figure 2.2, the revenues from hydrocarbons and mining accounted for 30\% or more of the total public revenues during 2010-2011 in Bolivia and Ecuador, and more than 40\% in the Bolivarian Republic of Venezuela.

\section{Assignment and distribution of tax revenues from the exploitation of nonrenewable natural resources}

The increase in tax revenues from the exploitation of nonrenewable natural resources was an important source of public revenues, not only for the central governments, as noted in the previous section, but also for the subnational

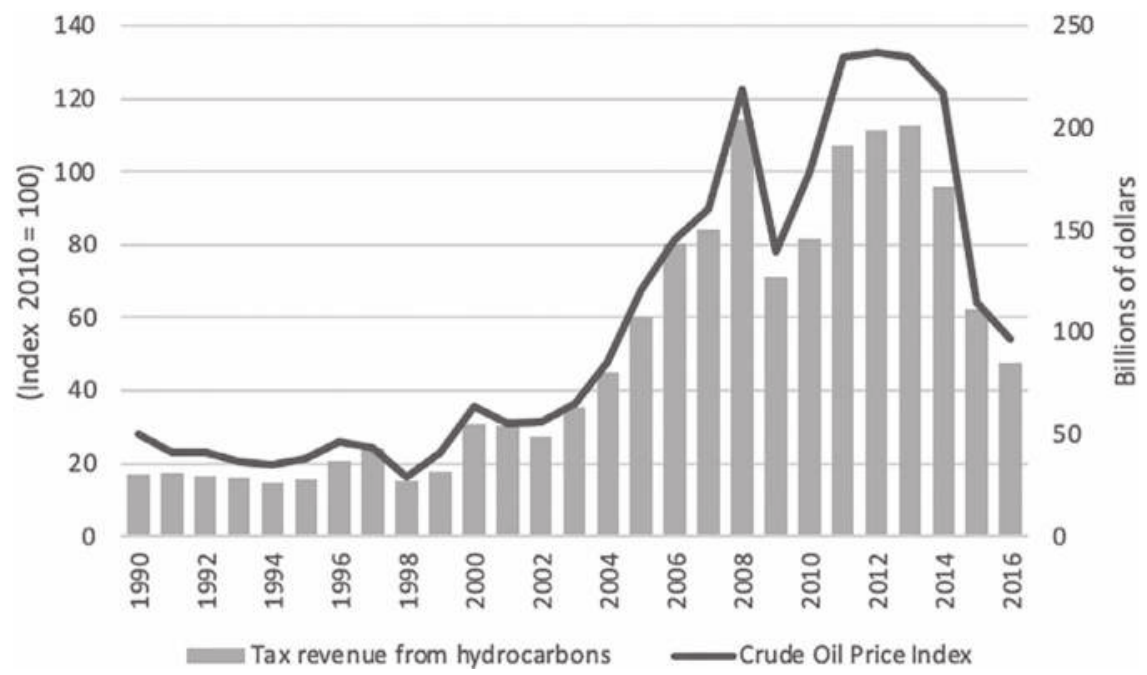

Figure 2.1a Latin America and the Caribbean: tax revenues from nonrenewable natural resources, by product, and related international price indicators, 1990-2016 $($ Index $100=2010)$ A. Hydrocarbons

Source: Hanni et al., 2018 


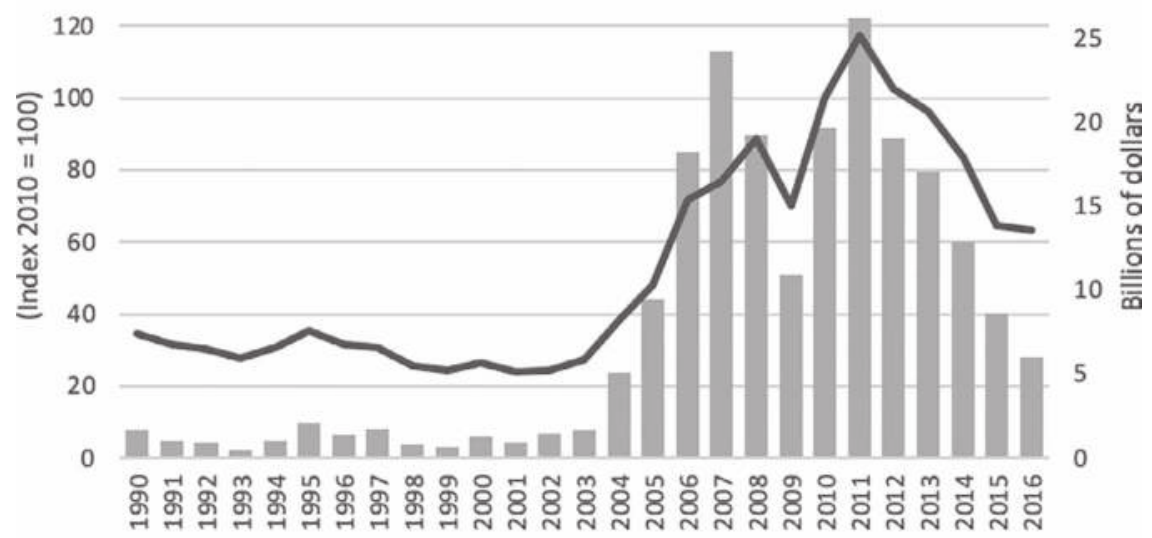

Tax revenue from mining Minerals and Metals Price Index

Figure 2.1b Latin America and the Caribbean: tax revenues from nonrenewable natural resources, by product, and related international price indicators, 1990-2016 (Index $100=2010)$ B. Mining Products

Source: Hanni et al., 2018

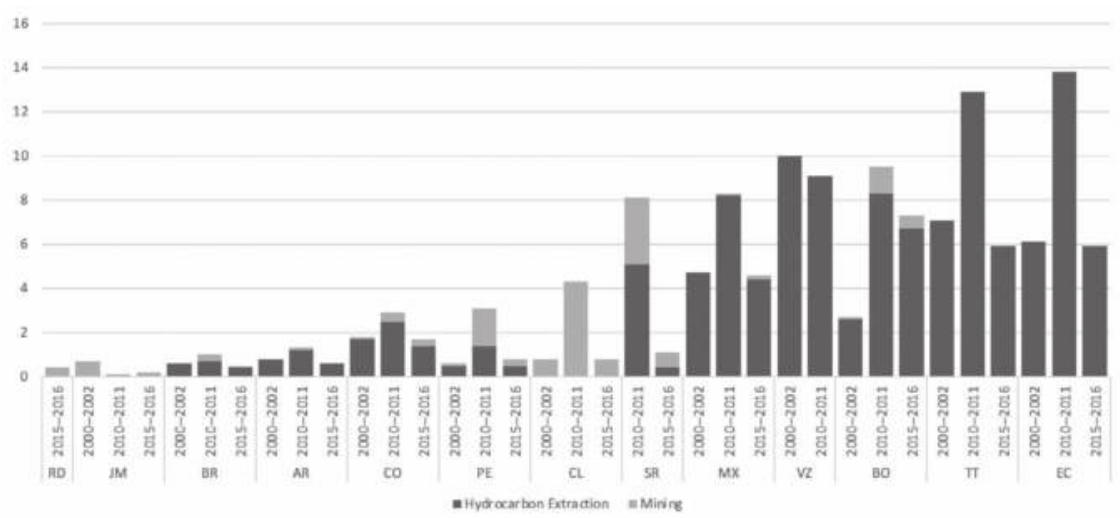

Figure 2.2 Latin America and the Caribbean (selected countries): participation of tax revenues from nonrenewable natural resources in total public revenues, 2000-2016 (Percentages)

Source: Hanni et al. (2018) 
ones (Brosio \& Jiménez, 2012). The use of this peculiar taxable base meant an improvement in the fiscal position of several subnational governments, especially in the regions where these products are produced.

Latin American countries in general, and the Andean region in particular, show a variety of different institutions for sharing rents from natural resources due to the different intergovernmental arrangements, ranging from classical federations, such as Argentina, to typical unitary states, such as Chile.

Contrary to old constitutions which remained silent on this issue, recent constitutions frequently, though not always directly, address it, because the sharing of rents from natural resources has become an inevitable component of the constitutional pact. Only in Argentina does the constitution assign ownership explicitly to the provinces. In all the other countries, ownership is assigned to the central government or is left unsettled by assigning ownership to the people (Bolivia), or to the nation (Peru). However, congruent with the international practice, rent sharing is not determined by the assignment of ownership, but rather by the sharing of tax bases, as in Argentina, and by the sharing of tax revenue.

With only two exceptions, Chile and Venezuela, all countries recognize the sharing of rent in favor of subnational governments. It is worthwhile noting that despite the fact that the first has always been a unitary and centralized country and the second has always been a federation, rent centralization prevailed in both countries.

The Andean countries represent an interesting example regarding the sharing issue. Bolivia, Colombia, Ecuador, and Peru are all unitary states that have embarked since the 1990 s on a decentralization process leading to the creation of regional systems. The same countries allocate a substantial share of their revenues from natural resources to their subnational governments. These countries provide evidence to the argument that the combination of political decentralization processes and large endowments of natural resources is a factor that renders centralization of natural resource rents politically impossible.

The degree of sharing of the fiscal revenues stemming from natural resources among subnational governments is also increasing over time, due not only to the discovery of the resources, but also to the relative youth of most Latin American constitutions (Ibid.).

Excluding Argentina and Ecuador, in the remaining countries, subnational governments situated in the non-producing areas have direct access to a portion of the rents stemming from natural resources. This is a notable feature of Latin America that has clear merits, once the principle of sharing rents with subnational governments is accepted. In classical federal systems across the world, only the subnational governments situated in the producing areas have direct access to the rents, while the inequalities deriving from the system of allocation are corrected by general equalization systems. In the Latin American countries, general equalization systems do not exist and the inequalities-created by the allocations of rents from natural resources to the producing areas-are, partially, corrected by expanding rent-access to non-producing areas, through 
natural resource or a commodity-specific tax sharing systems. This is the case of Bolivia, Brazil, and Peru.

Consequently, the impact produced by the use of the origin principle for allocation is compensated by the concomitant use of the derivation principle. In Colombia, a specific equalization transfer system, the Sistema General de Regalías, where only royalties contribute to its pool, is used to provide non-producing areas access to revenues.

While natural resource rent sharing expands the revenue sources of subnational governments, it also makes them subject to the volatility of price and production fluctuations, for which they are not particularly well equipped.

When shared only or predominantly with the producing areas, natural resources contribute to increasing horizontal imbalances. This is clearly the case of the Bolivian departments, although the government has recently taken a number of steps to spread the allocation also to non-producing areas, by increasing the rent share going to all municipalities.

The huge interdepartmental inequalities of Bolivia (Brosio et al., 2018) are to be attributed to the unique characteristics of the country, where royalties on natural resources are the only source of revenue for departments. Nonproducing departments are, as a consequence, completely dependent on central government redistribution. Since no general equalization transfer system exists in Bolivia and since the non-producing departments have only access to a share of the rents on oil and gas, the distribution of departmental revenues is highly unequal (Brosio \& Jiménez, 2012).

The case of Bolivia shows the negative impact on regional equality deriving from making subnational government revenues only dependent on natural resource rents. Argentina provides evidence for a different practice. As mentioned before, in Argentina only the producing provinces have direct access to the rents through their royalties. However, provinces have access to their own taxes and to a share of a pool of national taxes. Consequently, while oilproducing provinces have extremely high per capita revenue, no province is left with an unbearably low revenue level (Ibid.).

It is difficult to find research that addresses the question of the impact on regional equality deriving from giving municipalities access to the rents from natural resources. There is no easily manageable information at this local government level. However, there is scanty evidence showing, as expected, that the concentration and randomness of the allocation of royalties is much higher for municipalities. In some cases, royalties can reach astronomically high per capita amounts, increasing regional inequality.

In spite of this heterogeneity, linked to the historical trajectories and social and political processes specific to each country, some general trends can be identified with regard to the regional distribution of these resources. We observe a high asymmetric assignment of tax responsibilities and the distribution of the fiscal revenues from extractive activities to the producer regions (Brosio \& Jiménez, 2015), with a lack of compensation mechanisms to nonproducer regions. 
Some countries in the Andean region share their revenues from nonrenewable natural resources asymmetrically with their local governments. Asymmetrical sharing consists in assigning a fiscal instrument only to the subnational governments of the producing areas, such as the right of levying royalties on oil and gas assigned to the provinces of Argentina. Alternatively, it may consist in assigning a share of the revenue collected by the central government only to the producing areas, as in the case of royalties and income tax in the case of Peru or the hydrocarbon tax (IDH) in Bolivia.

Asymmetrical sharing is a non-necessary consequence of the spatial concentration on natural resources within countries. As a matter of fact, many countries do not use it, preferring to share the revenue with all local governments. Asymmetrical sharing can create huge horizontal imbalances among local governments compromising regional equality, efficiency, and national cohesion.

The fiscal revenues that are more concentrated are those coming from the nonrenewable natural resources sector (Table 2.1). This is a result of the

Table 2.1 Evolution of concentration of regional GDP per capita and subnational revenues: breakdown of revenues by fiscal revenues, tax revenues, and revenues from nonrenewable natural resources. Latin America (selected countries) 2000, 2007 and 2016

\begin{tabular}{|c|c|c|c|c|c|}
\hline \multirow[t]{2}{*}{ Countries } & \multirow[t]{2}{*}{ Year } & \multirow{2}{*}{$\frac{\text { Gap }(\max / \mathrm{min})}{\text { Regional GDP }}$} & \multicolumn{3}{|c|}{ Coefficient of variation } \\
\hline & & & $\begin{array}{l}\text { Fiscal } \\
\text { revenues }\end{array}$ & Tах revenues & $\begin{array}{l}\text { Revenues from } \\
\text { nonrenewable } \\
\text { natural resources }\end{array}$ \\
\hline \multirow[t]{3}{*}{ Argentina } & 2000 & 7.8 & 0.55 & 0.88 & 2.14 \\
\hline & 2007 & 7.6 & 0.63 & 0.78 & 1.97 \\
\hline & 2016 & $\ldots$ & 0.45 & 0.76 & 2.04 \\
\hline \multirow[t]{3}{*}{ Bolivia } & 2000 & 2.7 & 0.88 & 0.76 & $\ldots$ \\
\hline & 2007 & 4.1 & 1.08 & 1.58 & $\ldots$ \\
\hline & 2012 & 4.6 & 1.28 & 1.73 & $\ldots$ \\
\hline \multirow[t]{3}{*}{ Chile } & 2000 & 11.0 & 0.19 & 0.35 & 1.73 \\
\hline & 2007 & 9.2 & 0.25 & 0.39 & 1.70 \\
\hline & 2016 & 6.3 & 0.19 & 0.34 & 1.63 \\
\hline \multirow[t]{3}{*}{ Colombia } & 2000 & 15.7 & 0.79 & 0.85 & 2.72 \\
\hline & 2007 & 7.9 & 0.69 & 0.66 & 2.45 \\
\hline & 2016 & 6.2 & 0.81 & 0.58 & 1.39 \\
\hline \multirow[t]{3}{*}{ Ecuador } & 2000 & 19.1 & 0.67 & 0.90 & 0.73 \\
\hline & 2007 & 20.2 & 0.48 & 0.95 & 0.79 \\
\hline & 2015 & 8.4 & 0.55 & 0.56 & 0.71 \\
\hline \multirow[t]{3}{*}{ Peru } & 2005 & 6.2 & 0.88 & 0.96 & 1.92 \\
\hline & 2009 & 11.1 & 1.14 & 1.00 & 1.84 \\
\hline & 2016 & 4.7 & 0.50 & 0.85 & 1.83 \\
\hline
\end{tabular}

Source: Own elaboration based on official data.

Notes: The figure of the Regional GDP of Argentina for 2007 is taken from the last measurement of the GDP by province which corresponds to 2004 (see Cetrángolo, 2017). 
combination of the asymmetric allocation at the subnational level of tax revenues related to the exploitation of nonrenewable natural resources, coupled with the lack of equalization transfers. The significant concentration of regional GDP is also expressed in the high concentration of fiscal and tax revenues in the countries of the region.

An additional way to show the impact of asymmetric sharing on subnational fiscal inequality is through an indicator derived from the Gini coefficient, in order to capture the relative participation of different sources of revenues in the subnational fiscal inequality (Brosio et al., 2018). Following Lerman and Yitzhaki (1985) and adapting it to the subnational fiscal revenue structure, the Gini coefficient of regional inequality can be decomposed into three independent factors relating to the source of fiscal revenues (in this case it would be nonrenewable natural resources fiscal revenues) relative to the Gini coefficient of subnational fiscal revenues (own fiscal revenues, nonrenewable natural resources fiscal revenues, and other fiscal revenues). Therefore, for the source of revenue from nonrenewable natural resources, the sum of these three components (fourth, sixth, and eighth column) would represent their absolute contribution to total inequality.

Table 2.2 Relative participation in the inequality of subnational tax revenues

\begin{tabular}{|c|c|c|c|c|c|c|c|}
\hline \multirow[t]{2}{*}{ Country } & \multirow[t]{2}{*}{$\begin{array}{l}\text { Fiscal } \\
\text { instrument }\end{array}$} & \multicolumn{2}{|c|}{ Own revenues } & \multicolumn{2}{|c|}{$\begin{array}{l}\text { Revenues from } \\
\text { nonrenewable natural } \\
\text { resources fiscal }\end{array}$} & \multicolumn{2}{|c|}{$\begin{array}{l}\text { Other (transfers, } \\
\text { donations, etc.) }\end{array}$} \\
\hline & & $\begin{array}{l}\text { As } \star \\
\text { of total } \\
\text { revenues }\end{array}$ & $\begin{array}{l}\text { Relative } \\
\text { participation } \\
\text { in inequality } \\
\text { (GINI) }\end{array}$ & $\begin{array}{l}\text { As } \star \\
\text { of total } \\
\text { revenues }\end{array}$ & $\begin{array}{l}\text { Relative } \\
\text { participation } \\
\text { in inequality } \\
\text { (GINI) }\end{array}$ & $\begin{array}{l}\text { As * } \\
\text { of total } \\
\text { revenues }\end{array}$ & $\begin{array}{l}\text { Relative } \\
\text { participation } \\
\text { in inequality } \\
\text { (GINI) }\end{array}$ \\
\hline Argentina & Royalty & 34.6 & 24.7 & S.7 & 17.5 & 58 & 57.8 \\
\hline Bolivia & $\begin{array}{l}\text { Royalty } \\
\text { and tax on } \\
\text { hydrocarbons }\end{array}$ & 9.3 & 8.2 & 43.9 & 40.8 & 46.8 & 51 \\
\hline Colombia & Royalty & 28.1 & 13 & 24.7 & SI.7 & 47.2 & 35.3 \\
\hline Ecuador & Oil revenues & 9.9 & 6.1 & 14.7 & 11.9 & 75.4 & 81.9 \\
\hline Mexico & $\begin{array}{l}\text { Inter- } \\
\text { governmental } \\
\text { transfers } \\
\text { (participations) }\end{array}$ & 14.1 & 40.2 & 33.1 & 30.4 & 52.8 & 50.6 \\
\hline Peru & $\begin{array}{l}\text { Canon, } \\
\text { sobrecanon, } \\
\text { and royalties }\end{array}$ & 6.2 & -2.3 & 14.7 & 30 & 79.2 & 72.3 \\
\hline
\end{tabular}

Source: Own elaboration based on official data.

Coverage for Argentina is the provinces (2015); for Bolivia, autonomous governments, departments, and municipalities; in Colombia, departments and municipalities (2014); in Mexico were considered the federal entities, municipalities, and the city of México (2015); in Peru, local governments (2015). 
Asymmetric allocation consolidates, and in some cases amplifies, territorial disparities. In Table 2.1 and 2.2, a high relative participation of fiscal revenues from nonrenewable natural resources on subnational fiscal inequality can be observed.

Bolivia, Colombia, and Peru represent quite telling examples of the impact of nonrenewable natural resources on subnational finances. In these countries, the participation of this revenue exceeds the 30\% of the Gini composition. The case of Argentina should be highlighted, where the natural resource royalties are constitutionally assigned exclusively to the producing provinces. At an aggregate level, their weight within the total revenues is low, but their participation in the inequality of tax revenues between provinces is considerable (17\%).

The high impact on the inequality that may be related to allocation of these resources between levels of government makes it relevant to consider the design of equalization transfers as an alternative to improve interjurisdictional equity (Searle, 2007), particularly in Latin America and the Andean region. ${ }^{4}$

In addition, the high fluctuations in the prices of these products have resulted in highly volatile fiscal revenues and intergovernmental transfers from the exploitation of nonrenewable natural resources. For example, with regard to the volatility of the resources of the mining canon in Peru, the year-to-year variations of the transferred resources have changed from a maximum of $167 \%$ to a minimum of 20\% (Brosio \& Jiménez, 2015). These fiscal revenue variations make it very difficult for the governments (whether local, regional, or even central) to maintain an adequate and sustainable level of public spending, without a high loss of efficiency and equity in the provision of services and benefits.

\section{Conclusion and challenges}

Beyond the efforts of productive diversification, most of the countries of the Andean region are characterized by their high specialization in products from the extractive sector. This characteristic, coupled with the high volatility of the prices of these products, which today is expressed in the post-boom but a decade ago was expressed in the supercycle, meant strong fluctuations in tax revenues, whether at the level of central or subnational governments.

In the previous decade, the Andean countries experienced a particular stage in their economic history, driven in part by the upswing in commodity prices. This fact manifested in sustained processes of high economic growth and great improvements in social indicators, such as poverty and income inequality. These improvements were achieved in part by the adequate measures taken by policy makers throughout the region, who sought to take advantage of the promising external context of high commodity prices. Among the sample countries, an important fact behind these improvements was a stronger fiscal position attained through various tax reforms.

In this sense, it can be seen how these countries implemented a wide array of reforms taking different approaches that granted a high degree of heterogeneity among them. This is how an amplification of the state ownership took 
place, either through nationalizations in the hydrocarbon sector like in the case of Venezuela or Bolivia, or through renegotiation of contracts in Ecuador also through the strengthening of existing instruments or the introduction of new ones, such as royalty income tax and specific taxes in Bolivia, Ecuador, Colombia, Peru, and Chile, an aspect of great relative importance in the mining sector, where historically the state participation has been reduced; and through the implementation of taxes, duties, participations, or contributions linked to prices or extraordinary profits in several countries, given the high volatility of international prices of nonrenewable resources.

In the post-boom, a context of declining oil and mineral prices poses major challenges to the Latin American economies that are producers/exporters of these products. A heterogeneous impact can be expected. In some countries, the effects will be more pronounced, due to specific characteristics such as the share of the nonrenewable resources in their export structure or the fiscal instruments applied to them. Anyway, at a general level the bonanza cycle led to a partial reversion of the process of diversification that allowed it to increase manufacturing exports. As a result, the share of primary goods and nonrenewable resources and other intensive products in the export structure of the countries concerned increased again (Hanni et al., 2018).

To address the challenges that the actual international scenario poses over the countries analyzed in this chapter, it is not enough just to consider the fiscal impacts on the aggregate, as is usually done in the literature on the subject. Policy makers should also embrace the different mixes of fiscal impacts, which had been and will be heterogeneous among all of the countries analyzed. Lower prices of commodities would mean that these countries should make the necessary efforts to keep their spending budgets in direct relation to potential decreases in fiscal revenues by seeking to diversify sources of revenue, avoiding excessive dependence on exports of nonrenewable resources, through the strengthening of other less volatile tax bases such as property taxes or personal income tax, and implementing countercyclical fiscal mechanisms such as stabilization and saving funds. Other bases such as VAT are more extended throughout the analyzed countries, and direct taxes show a greater margin and are more progressive in distributional terms. Although the impact will be different among the countries, it is crucial that they keep their instruments and tax regimes under analysis and gradually improve them to maximize value and minimize the state's balance of tax collections from extractive sectors.

The post-bonanza has meant, at the level of the central governments, not only a fall in the fiscal relevance of these revenues, but also a reconsideration of the objectives to follow and the tools to use, so as to prioritize not only the fiscal result but also the sustainability in the investments and production of the sector. In the boom period, governments sought to increase fiscal revenues from the sector and their share in the economic rents generated; as prices plummeted, these efforts were moderated or even receded as governments sought to protect production and investment. 
This is a difficult process and must be done with care since there are multiple trade-offs between the different evaluation criteria of fiscal instruments, requiring some balance between the different objectives. This means, for example, maintaining reasonable investment dynamism and achieving, at the same time, a progressive state participation in economic rents derived from natural resource extraction; achieving an adequate sharing of risks among the government and the investors by the means of tax arrangements that can transfer part of the commercial risk that entrepreneurs face to the government; and assuring compliance with a reasonably low administrative cost.

At the central government level, one of the main challenges for countries producing nonrenewable natural resources is to balance the need to close fiscal gaps and to ensure fair participation in the economic income generated by the extractive activity. As emphasized in the chapter, each one of the fiscal instruments analyzed has advantages and disadvantages in light of the objectives pursued by governments. It is essential to find a balance between the need to obtain tax revenues with the rest of the typical tax objectives (efficiency, progressiveness, equity, stability, flexibility) in order to guarantee a flow of public revenues while ensuring the sustainability of investment and production in the sector.

On the intergovernmental allocation and distribution side, the challenges are related to how to avoid the high concentration and significant volatility of these resources. Resulting asymmetries point out to the need to revise those tax assignments from the exploitation of nonrenewable natural resources. In the event that these assignments promote a high concentration of income, the design of equalization transfers that make it possible to compensate for the different resulting capacities can be of great help. The post-boom situation, with prices still below those recorded during the bonanza, can be a good opportunity, in terms of political economy, to move forward with less resistance from the authorities of producing jurisdictions in reforms in the allocation systems and distribution of these resources.

\section{Notes}

1 I appreciate the support and collaboration of Maria Gil Mendoza and Ignacio Ruelas; and the comments of Giorgio Brosio, Barbara Fritz, Bettina Schorr, Gerardo Damonte, Andrea Podestá, and Hans-Jürgen Puhle.

2 For more details about the implementation of fiscal reforms in that period, see Hanni, Jiménez and Ruelas (2018)

3 In some of these cases, for example in Peru, since the amending of Mining Royalties Law in 2011, not only the levels of taxation have been altered but scales of varying rates were established according to easily verifiable criteria, like the level of production, location and depth of the wells, the type of resource extracted, or other variables related to the cost structure (see Hanni, Jiménez \& Ruelas, 2018).

4 Brosio and Jiménez (2015) and Brosio, Jiménez \& Ruelas (2018), taking as reference the theoretical principles of interjurisdictional fiscal equity, review the high impact of the exploitation of natural resources on the territorial distribution of fiscal revenues and the effect of the implementation of equalization transfer systems, including fiscal revenues from natural 
resources, at the level of the intermediate governments of Argentina and Peru. In both cases, territorial fiscal revenue inequality falls significantly if these revenues are distributed with equalization mechanisms.

\section{References}

Acquatella, J., Altomonte, H., Arroyo, A., \& Lardé, J. (2013). Rentas de recursos naturales no renovables en América Latina y el Caribe: Evolución 1990-2010 [Serie Seminarios y Conferencias $\left.N^{\circ} 72\right]$. Naciones Unidas. ISSN 1680-9033.

Brosio, G., \& Jiménez, J. P. (2012). The intergovernmental allocation of revenue from natural resources: Finding a balance between centripetal and centrifugal pressure. In G. Brosio \& J. P. Jiménez (Eds.), Decentralization and reform in Latin America (pp. 290-320). Edward Elgar Publishing. https://doi.org/10.4337/9781781006269.00016

Brosio, G., \& Jiménez, J. P. (2015). Equalization grants and asymmetric sharing of natural resources: Options for Latin America. Urban Public Economics Review, 21, 12-63. www. redalyc.org/articulo.oa?id $=50443064001$

Brosio, G., Jiménez, J. P., \& Ruelas, I. (2018). Territorial inequality, equalization transfers and asymmetric sharing of nonrenewable natural resources in Latin America. CEPAL Review, 126, 63-85. hdl.handle.net/11362/44558

Cetrángolo, O. (2017, July 20). ¿Qué sabemos sobre las estructuras productivas regionales? Nuevos Papeles (NP). www.nuevospapeles.com/nota/4549-iquest-que-sabemos-sobre-lasestructuras-productivas-regionales

Comisión Económica para América Latina y el Caribe-CEPAL. (2013). Panorama fiscal de América Latina y el Caribe 2013: Reformas tributarias y renovación del pacto fiscal. Naciones Unidas.

Comisión Económica para América Latina y el Caribe-CEPAL. (2017). Panorama fiscal de América Latina y el Caribe: La movilización de recursos para el financiamiento del desarrollo sostenible. Naciones Unidas. ISBN: 978-92-1-058580-4

Gómez Sabaíni, J. C., Kacef, O., \& Morán, D. (2018). International insertion, volatility and fiscal resources in countries specialized in extractive industries: Between a rock and a hard place? In J. Atria, C. Groll, \& M. F. Valdés (Eds.), Rethinking taxation in Latin America (pp. 123-158). Palgrave Macmillan.

Hanni, M., Jiménez, J. P., \& Ruelas, I. (2018). Ciclo de precios y regímenes fiscales vinculados con los recursos naturales no renovables en América Latina y el Caribe. CEPAL, Serie Macroeconomía del Desarrollo, 195. http://hdl.handle.net/11362/44239

Lerman, R., \& Yitzhaki, S. (1985). Income inequality effects by income source: A new approach and applications to the United States. MIT Press, The Review of Economics and Statistics, 67(1), 151-156. https://doi.org/10.2307/1928447

Muñoz, A. F., Radics, G. A., \& Bone, C. (2016). Subnational fiscal disparities and intergovernmental transfers in LAC. Review of Public Economics, 219(4), 35-66. https://doi. org/10.7866/HPE-RPE.16.4.2

Searle, B. (2007). Revenue sharing, natural resources and fiscal equalization. In J. MartínezVázquez \& B. Searle (Eds.), Fiscal equalization: Challenges in the design of intergovernmental transfers (pp. 371-401). Springer. https://doi.org/10.1007/978-0-387-48988-9 


\title{
3 Cash transfers as citizens' dividend of the resource boom
}

\author{
Opportunities and challenges of social \\ protection in Bolivia
}

\author{
Pablo Evia Salas
}

\section{Introduction}

Hydrocarbons play a crucial role in the Bolivian economy. According to data from the National Institute of Statistics (Instituto Nacional de Estadística, 2020), sectoral GDP had cumulative growth of $70 \%$ in the 2000 s, compared to average growth in the 1990s (around 4\%). Likewise, its role in Bolivian exports is significant: 40\% of export earnings in the timespan 2000-2018 came from this sector (Banco Central de Bolivia, 2019). In addition to being important from an economic point of view, hydrocarbons play a strategic role in Bolivian politics. No other sector from the industry has been subject to such varied institutional reform in a (relatively) short time horizon, influenced by the growing importance of the sector in its potential to increase the government revenues, mainly through tax collection.

This chapter explores the interaction between social policy innovations, understood as a type of institutional change, and the resource boom in Bolivia during 2003-2014 and raises a couple of questions regarding their sustainability. A series of reforms related to natural resources were introduced in Bolivia in the 1990s. These reforms paved the way for gathering more revenues from the natural resource sector (mainly natural gas), which allowed the successive governments to try to build a social protection system reflecting these increased fiscal revenues. They could, thus, be understood as a citizens' dividend of the resource boom (Arezki et al., 2012, p. 30).

The importance of these social protection innovations in overcoming the high poverty and inequality rates present in the country is generally accepted (Amarante \& Brun, 2018; Robles et al., 2019). However, in some periods, the social protection policy lacked the necessary financial support to be financially sustainable, which introduced social, fiscal, and political pressures that ended up twisting the objective under which they originally were conceived. In this sense, the social protection system in Bolivia faces some constraints and challenges that could compromise its financial sustainability and potentially put in danger the funding of the system and the support provided to its beneficiaries.

The institutional drivers of social policy innovations in Bolivia are mixed: First, there has been a strong regional influence in terms of social protection policies based on rigorous evaluations (Bolsa Família in Brazil, Oportunidades 
in Mexico). In fact, this type of policy influenced not only Bolivia but other countries in the region that adopted social protection schemes based on cash transfers (both conditional and unconditional).

On the other hand, innovations in social policy were also endogenously driven by the resource boom due to their discovery and subsequent boom in commodity prices. The flow of additional resources had to find a use by the government (apart from minimum wage increases, increased infrastructure investments, etc.), and therefore the establishment of conditional and unconditional transfers was propitious, as well as a way to create a political support base for the government of the party Movimiento al Socialismo (MAS, Movement towards Socialism), headed since 2006 by President Evo Morales (until 2019).

The remainder of the chapter consists of the following: Next, I discuss the background of the conception and implementation of the central social transfers after the economic reforms (1990s) and the natural resource's boom (2000s). Following that, I analyze the fiscal sustainability of the Bolivian social policy alongside its funding rationale, stressing some of its weaknesses and potential risks. In the last section, I will get into the challenges and the future of social protection in Bolivia, trying to conceive it as a life cycle-oriented policy.

\section{Background of social policy in Bolivia: domestic reforms and global boom}

The foundations of contemporary social policy in Bolivia could be traced back to the 1980s, in which a profound crisis unleashed an unprecedented erosion in the living conditions of most Bolivians, and predominantly the poorest and vulnerable. The collapse of international tin prices triggered a massive adjustment of the role of the government in the economy (which was the main employer of the country). This adjustment implied a massive layoff of workers, with the additional harmful consequences of the loss of purchasing power due to an episode of extremely high inflation (Antelo, 2000). At that time, the creation of the Fondo Social de Emergencia-Social Emergency Fund as an entity that supported the most vulnerable through the implementation of economic infrastructure, social assistance, and productive counseling installed the basis of social policy in the country based on direct government support (Romero, 1988).

Despite these efforts, poverty rates remained in the range of 50-70\% in the aftermath of the 1980s hyper-inflation episode. Since then, successive governments have tried to introduce market reforms in the country to try to correct the macroeconomic disequilibrium and recover the path for economic growth. In 1993, President Gonzalo Sánchez de Lozada started to implement another package of reforms aiming at modernizing state administration. These reforms included a substantial component in the hydrocarbons sector. Due to the sector's lack of investments, production had stagnated without further exploration activities undertaken by Yacimientos Petroliferos Fiscales Bolivianos (YPFB), a stateowned firm. In this sense, an essential part of the reforms during the 1990s included the attempt to invigorate the hydrocarbons sector through market reforms, including its partial privatization, to attract foreign investment. 
These reforms effectively appealed to a number of multinational firms working in the sector (AMOCO, Pérez Companc, ENRON, among others), which became involved in the business through the purchase of stock in the previously state-owned company, YPFB. The investment commitments of foreign capital enhanced the position of Bolivia in the hydrocarbon business at the regional level, including the construction of a natural gas pipeline to Brazil, which was a huge market for Bolivian hydrocarbons.

This privatization scheme included a social policy component: the BONOSOL (Bono Solidario-Solidarity Bond). BONOSOL consisted of a cash transfer paid annually to all Bolivian citizens proven to be 65 years old or older, using the profits of the partially privatized hydrocarbons companies. The BONOSOL's amount was initially about USD257 per year at the present exchange rate (USD1 = Bs7). As the byproduct of the hydrocarbons' reform, BONOSOL constituted the first cash transfer that is still part of the current social policy infrastructure. The following government of Banzer-Quiroga (1997-2002) renamed it as Bolivida and, given the economic crisis of the early 2000s, reduced the amount of the pension to only USD65 yearly.

The reforms in the hydrocarbon sector implemented by the first government of Sánchez de Lozada started to show results soon: new reserves of natural gas were discovered, and production increased in a spectacular way. Talks began to facilitate the exports of part of these additional reserves to foreign markets, the most important one being the Mexican and American markets.

In parallel to this incipient boom, Bolivia experienced during the years 2000 and 2005 a series of dramatic episodes of social upheaval and mobilizations including a social revolt against the privatization of water provision in the city of Cochabamba (the Water War), several weeks-long blockades of the Bolivian altiplano headed by the Aymara leader Felipe Quispe, and a revolt against a new direct income tax in February 2003 (Black February) led by the police forces. During "Black October" in 2003, also known as the War over Gas, weekslong massive protests took place against the plans of the second government of Gonzálo Sánchez de Lozada (2002-2003) for exporting Bolivian natural gas via a Chilean port. Many Bolivians objected to the selection of Chile because of the historical memory of Chile usurping Bolivia's access to the Pacific Ocean.

Black October terminated the presidential mandate of Gonzalo Sánchez de Lozada, forcing him to go into exile in the United States. Sánchez de Lozada's resignation resulted in the automatic succession of Vice President Carlos Mesa, who drafted a new law governing the hydrocarbons sector based on the results of a previously conducted popular referendum. This new law increased the taxes raised by the government to $50 \%$ of hydrocarbons' production, from the $18 \%$ established by Sánchez de Lozada. In this way, tax revenues from hydrocarbon production were dramatically increased. In 2005 the government received a total of USD607 million, which meant an increase of $112 \%$ compared to 2004 (USD286 million). At the same time, it motivated an intense conflict over the distribution of these windfalls among regions, local governments, and other stakeholders (such as public universities).

After this new round of intensive social protests, in December 2005 the leader of the coca grower union Evo Morales won the Bolivian presidency with 
approximately $52 \%$ of the votes, which meant the most resounding victory for a candidate for the presidency since the restoration of democracy in 1982. Morales won on the basis of an electoral campaign that promised the nationalization of the countries' natural resource sector. In May 2006, President Morales' government then issued the Supreme Decree Héroes del Chaco, ${ }^{1}$ declaring state ownership of all hydrocarbons. According to the decree, all oil- and gas-producing companies were obliged to hand over their hydrocarbon production to the public company YPFB. At the same time, YPFB assumed the commercialization of and definition of the conditions of sale, volumes, and prices of all hydrocarbons.

A transition period was established during which the existing contracts with foreign oil companies were readjusted and reformulated. Also, those oil fields whose production was greater than 100 million cubic feet per day were subject to an additional $32 \%$ tax on their production value. This percentage was added to the 50\% tax established in the new Hydrocarbons Law issued in 2005, making a total of $82 \%$ in taxes belonging to the state.

As a consequence of this reform, the state's revenues (both national and subnational) again increased steeply. In 2005 the government collected approximately USD333 million in hydrocarbons' taxes, while this figure rose to almost USD790 million in 2006, and to USD2,241 million in 2014 (Figure 3.1).

The increase of public revenues not only depended on the changes in the hydrocarbons' regulation, which increased the tax rate from 18\% (Sánchez de Lozada) to $50 \%$ (Carlos Mesa) and 82\% (Evo Morales) of the production value. Another factor allowing the boom in the hydrocarbons sector was the increase in the international price of oil, which is closely linked to the price of natural gas. As the price of oil increased, so did the export price of natural gas.

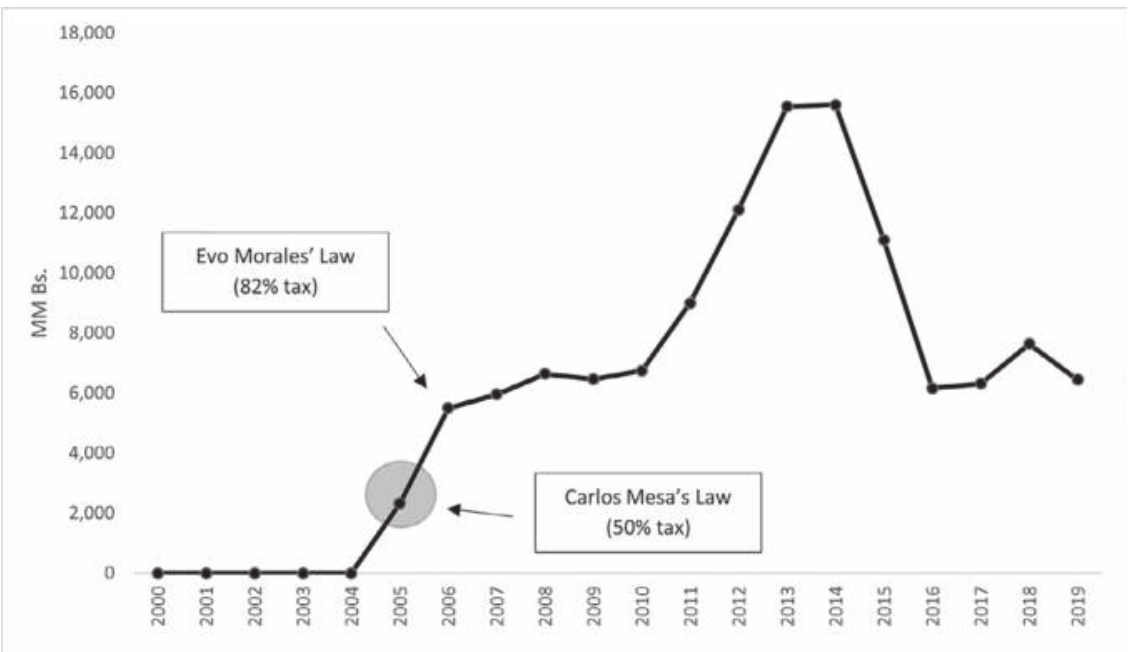

Figure 3.1 Hydrocarbons' taxes under different regimes (in millions of bolivianos)

Source: Own elaboration using data from Unidad de Análisis de Políticas Económicas y Sociales (UDAPE): www.udape.gob.bo/ 


\section{Pablo Evia Salas}

The boom in the hydrocarbons sector triggered a steady increase in government revenues, but also in expenditures. As Figure 3.3 depicts, government revenues and expenditures increased substantially from 2006 onwards. In the eight years from 2006 to 2013, the fiscal balance showed a surplus (as a matter

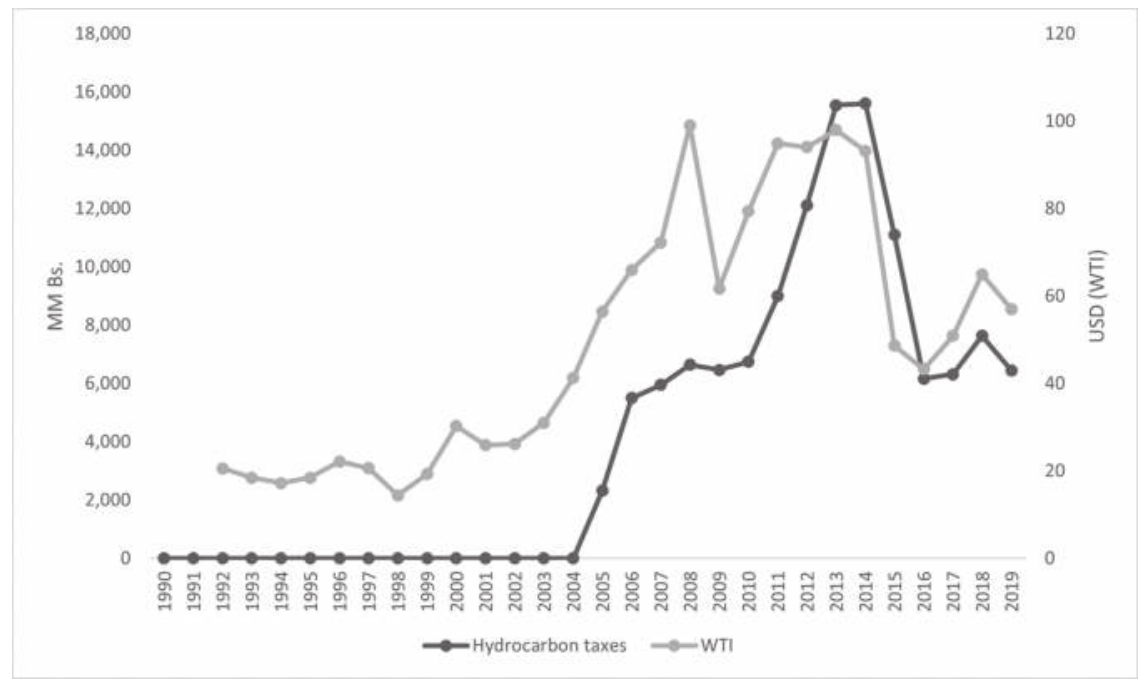

Figure 3.2 Hydrocarbons' tax and WTI

Source: Own elaboration using data from UDAPE

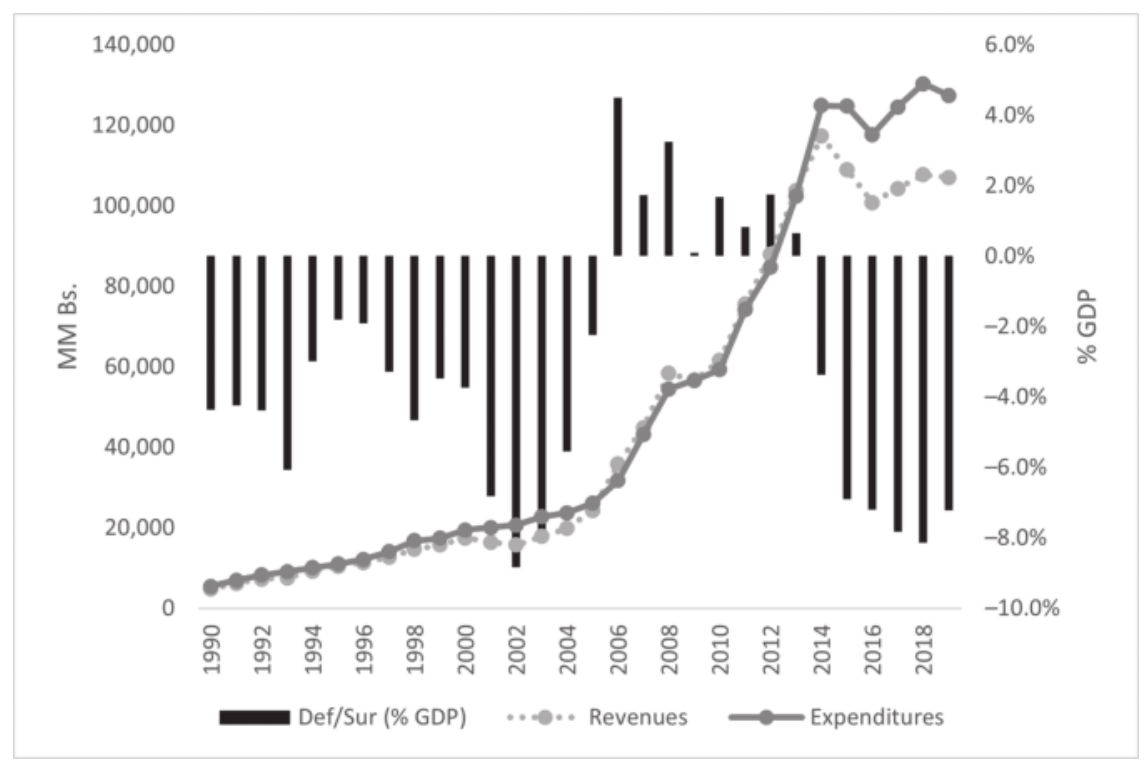

Figure 3.3 Fiscal balance, government expenditures and revenues

Source: Own elaboration using data from UDAPE 
of fact, the first surplus in 30 years). Some authors even drew parallels between it and the Marshall Plan of US aid to Western Europe. Morales (2014) calculated that during the booming period (2005-2013), the additional inflow of resources was around USD50 billion compared to USD130 billion under the Marshall Plan. However, the Bolivian fiscal balance benefited only temporarily during the phase of high oil prices. After 2013, and coinciding with the drop in the international oil price, the surplus turned into a deficit, reaching levels coincident with the crisis years (2002-2003).

\section{Bolivia's social protection floor}

With the extraordinary influx of revenues and following the example of other programs in the region (especially Oportunidades in Mexico and Bolsa EscolaBolsa Família in Brazil), the government of Evo Morales intended to establish a social protection system based in conditional cash transfers (CCTs) (Cechinni, 2019; Sojo, 2017).

CCTs consist of payments given to specific individuals provided that they fulfill certain conditions: for example, attending school or being subject to periodical medical check-ups. Those transfers intend to address poverty in the short term and break the intergenerational cycle of poverty by increasing the human capital of the recipients and their families (Ferreira \& Robalino, 2010, p. 22). Effective targeting is one of the features of CCTs that improve their effectiveness in reducing poverty.

In the Latin American region, the pioneering examples of Progresa-Oportunidades in Mexico and Bolsa Escola-Bolsa Família in Brazil during the 1990s inspired many other programs that rely upon conditional cash transfers. Ferreira and Robalino (2010) estimate that CCTs in Latin America benefit roughly 22 million households, range from 0.1 to 0.6 of GDP, and cover between $1.5 \%$ of the population (El Salvador) and $54 \%$ of the population (Bolivia). Thus, the social protection floor installed in Bolivia is one of the most extensive in the region and is considered key in the fight against poverty (Amarante \& Brun, 2018).

In current Bolivia, the most prominent cash transfers are BONOSOL/Renta Dignidad, a universal pension scheme given to the elderly; Bono Juancito Pinto (BJP), a conditional transfer given to children and youth in school-age; and Bono Juana Azurduy (BJA), another conditional cash transfer provided to expectant mothers and their newborns. The establishment of BJA and BJP aimed to increase the coverage of social protection recipients and, at the same time, to break the intergenerational cycle of poverty. The continuation of past programs, like BONOSOL/Renta Dignidad, contributed to reinforce this idea of providing integral support to the individual throughout their life cycle. Hence, the social policy system established in Bolivia resembles the Social Protection Floor (SPF) concept as promoted by the International Labor Organization (ILO, 2011). The ILO conceives SPF as an integrated set of social policies designed to guarantee income security and access to essential social services for all, paying particular attention to vulnerable groups and to protecting and empowering people across the life cycle (Harris, 2013, p. 113). In terms of its funding, SPF is essentially non-contributory and involves funding using public resources. 


\section{Unstable finances: a constraint for the future?}

There can be different sources to fund a social protection scheme. Generally, domestic resource mobilization is considered as the most efficient way of financing development (Harris, 2013, p. 117). Likewise, the literature warns against funding social protection with external sources because of their potential unsustainability. The notion of the project cycle unsustainability is frequent in those social protection schemes funded by external donors and implies that the horizon of planning of the institutions that provide support reaches up to four or five years. Usually, the donors or NGOs that finance social protection schemes in developing countries have a small window of commitment. The same idea applies to social protection schemes that are funded using volatile revenues, like taxes on commodities (Devereux, 2002, p. 31). The problem of financing social protection schemes (or social protection systems, as SPF) with natural resources taxation is that, in general, this funding is pro-cyclical and subject to the fluctuations of commodities' international prices (Loza, 2007). Moreover, if the transfers are funded using debt, this would reduce fiscal space in the future, limiting even more the use of the resources by the government (Harris, 2013, p. 127).

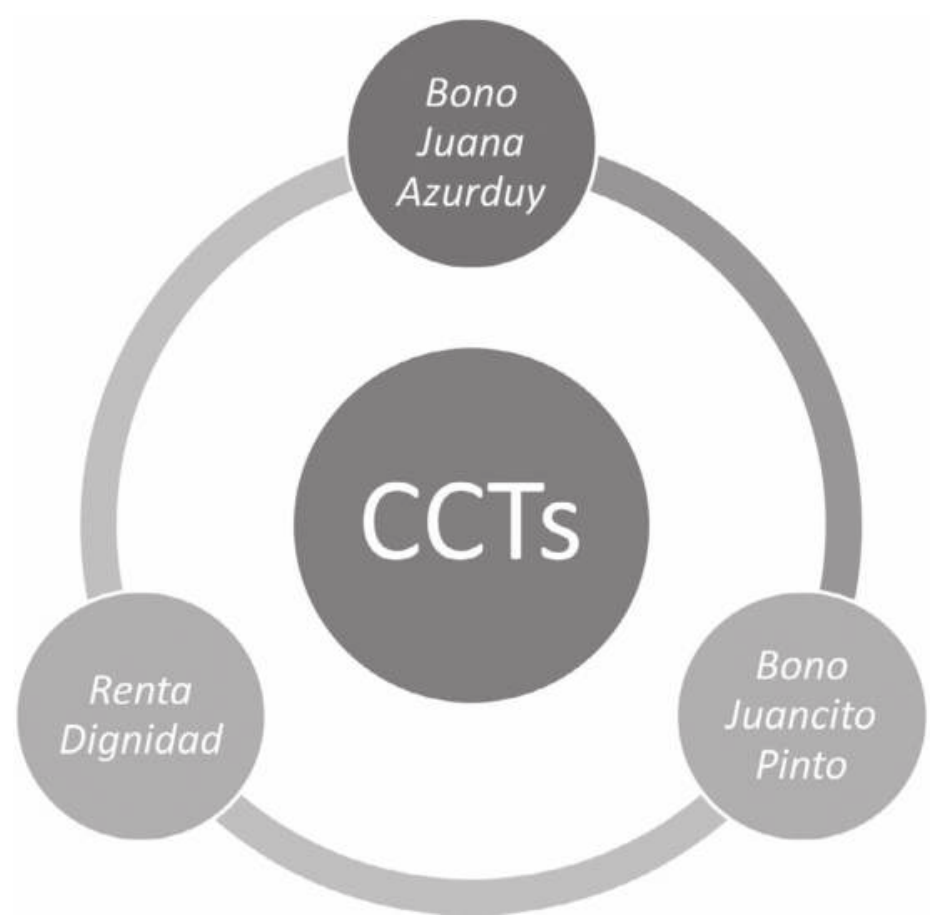

Figure 3.4 Bolivian CCTs and life cycle

Source: Own elaboration based on Millán et al. (2019) 
These dynamics can be observed in Bolivia and raise serious doubts regarding the financial sustainability of the domestic social protection floor enacted as a citizens' dividend of the resource boom. As explained before, reform of the hydrocarbons sector increased fiscal resources a great deal. These additional fiscal resources allowed the financing of existing social programs (Renta Digni$d a d$ ) and the creation of new ones (BJA, BJP) (Medinaceli \& Mokrani, 2010, p. 248). In this way, natural resources turned into the primary funding source for social purposes (Monterrey, 2013), linking expenditure on social protection with volatile international prices. When the economic boom ended, revenues decreased while expenditures remained high. As a consequence, in 2019, the fiscal deficit worsened to reach $8 \%$ of GDP, raising serious questions regarding the predictability of the social protection programs.

In the following, I illustrate this set of potential problems in detail for the three most important conditional cash transfer programs in Bolivia: Renta Dignidad, Bono Juana Azurduy, and Bono Juancito Pinto.

\section{BONOSOL/Renta Dignidad}

From its inception in the 1990s, the payment of BONOSOL was highly controversial due to the perception that the dividends of capitalized enterprises did not sufficiently back the resources needed for its payment (Müller, 2009). Indeed, the program faced problems of financial sustainability from the beginning. In its first payment in 1997, the BONOSOL amount of Bs1800 (roughly USD257) demanded a budget of USD90 million for paying the benefit to more than 360,000 recipients. However, the dividends of privatized enterprises only reached USD45 million. The remainder had to be covered by the Tesoro General de la Nación (TGN), the public budget in an amount of USD45 million (Gamboa, 2006).

Given this scenario, the payment of Bs1800 was largely unsustainable, and the amount was reduced to Bs455 (around USD65) from 1998 to 2001. In the year 2002, there was no payment of BONOSOL or Bolivida, while from 2003 to 2006 the amount and original name of BONOSOL were restituted.

Shortly after the new government of Morales had assumed in 2006, the BONOSOL scheme was changed to a monthly transfer of Bs350 (around USD50). The law that created Renta Dignidad (the "new" transfer) established the following points: the Renta Dignidad would reach all elderly more than 60 years old; those that had another pension benefit would only receive $75 \%$ percent of the benefit (USD37.50); and most importantly, the funding of the Renta Dignidad would be grounded in two sources: the dividends of the privatized enterprises, in the proportion that corresponds to the Bolivian stockholders and $30 \%$ of the newly established direct Hydrocarbon Tax (IDH-Impuesto Directo a los Hidrocarburos).

While the first two changes in the legislation implied a different design of the transfer, the most important modification came in the cash transfer funding. While BONOSOL payment was covered using the privatization profits, a link between social policy and the revenues from the exports of 
natural gas was created with the establishment of Renta Dignidad. Thus, as long as the government had high revenues due to favorable external circumstances (i.e., a boom in the commodities sector due to a hike in the international prices), the tax revenues designated to finance the transfer would be assured. However, in a highly volatile context, in which commodity prices are subject to demand and supply shocks, it would be, to say the least, a risky business to heavily rely upon hydrocarbons revenues to finance a cash transfer program.

And indeed, with the bust cycle sending international commodity prices plunging, the funding of the program became troublesome. Figure 3.5 shows the evolution of funding sources for Renta Dignidad. As can be seen, the component regarding the privatization revenues has evolved mirroring the hydrocarbons tax component: when the privatization revenues arise, there is less need to trust in the hydrocarbon tax component, and the converse is also true. In the last years, however, it can be seen that the component regarding the dividends of the privatized companies has evolved negatively, falling to a historical minimum, only comparable to the revenues in 2012.

Bolivia's funding of its Renta Dignidad provides an interesting example of the use of revenues from the exploitation of natural resources to fund social protection expenditures and highlights the potential pitfalls posed by the variability of such revenues. Buoyant oil prices allowed the program to be funded using only a part of the oil revenues. However, Bolivia's experience underscores that provisions also have to be made to secure funding when oil prices are less favorable and absorb

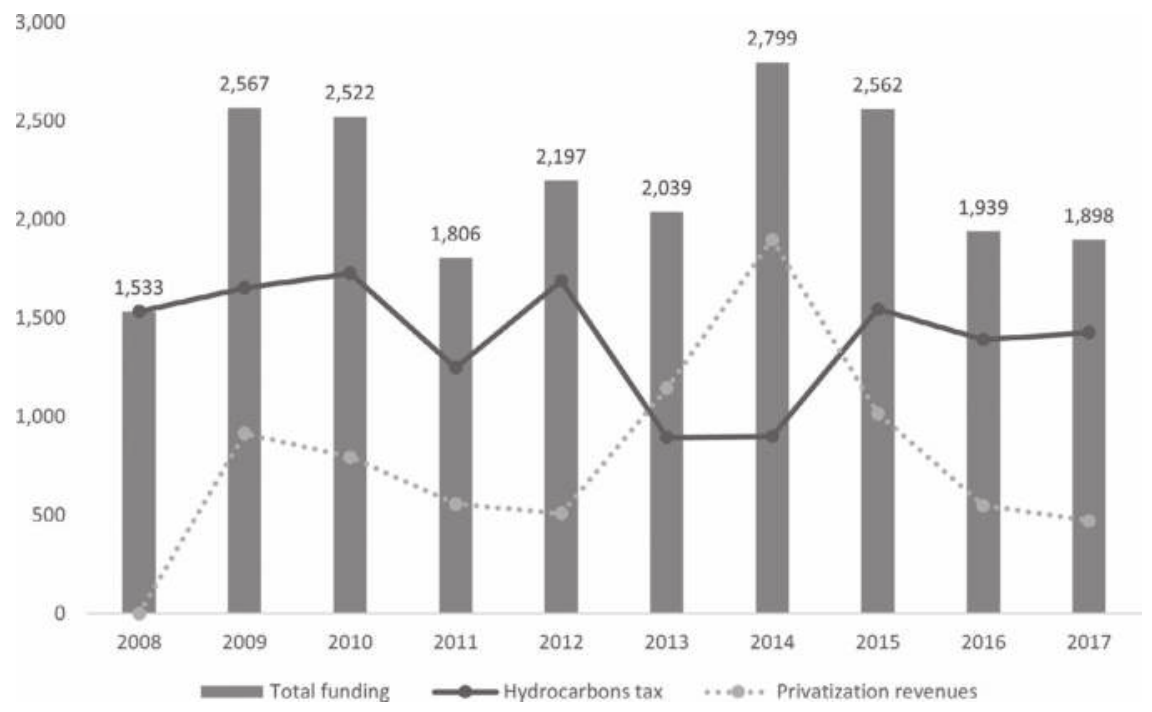

Figure 3.5 Renta Dignidad funding, hydrocarbons tax, and privatization revenues

Source: Own elaboration using data from UDAPE 
the impact of the inherent volatility of oil revenues, given that they are one of the most critical sources of funding for the government's overall expenditures (Harris, 2013, p. 133).

While the link between highly volatile oil prices and the revenues needed for the cash transfers to Bolivian pensioners has not had actual negative consequences for the payment of the transfer (e.g., a reduction in amount of benefit or in the number of recipients), there are some challenges regarding its sustainability over time. In the first place, there is a general concern with respect to the reduction in public resources due to the drop in oil prices observed in the last five years (Sánchez \& Velásquez, 2020). Several experts have expressed their belief that the resources collected by the national treasury will not be able to cover the total expenditure needed for Renta Dignidad, not to mention retirement income in general (Rodríguez Cáceres, 2021). The second concern is the high volatility of the source of funding for Renta Dignidad. While the bonanza from the middle 2000s to 2010s has allowed the government to sustain and even increase the amount of the Renta Dignidad over time, unstable oil prices will make it harder to adopt a similar pattern in the following years.

\section{Bono Juancito Pinto}

The Bono Juancito Pinto was established in 2006, and it consists of the payment of Bs200 (USD28) annually to school students (both primary and secondary school) that are enrolled in public schools. The payment is conditional on an attendance rate of more than $80 \%$ of the school days during the previous school year (running from February to November).

While the funding mechanism is not specific regarding the funding source for the transfer payment, de facto it was financed by the revenues generated by the "nationalized" hydrocarbons enterprise, YPFB. Thus, also this transfer is inherently linked to the volatile hydrocarbons revenues.

As in the case with Renta Dignidad, in the first years of the transfer the resources provided by YPFB were enough to cope with the financial obligations of the program. However, with the revenues shrinking and the overall budget expanding (in 2006, the budget was USD248.5 million; in 2019, the budget was USD461 million), additional funding sources had to be found considerably increasing the number of revenues' sources comparing it to its first payment in 2006. In 2019, besides YPFB, these include a variety of public sources ranging from food firms to commercial banks to the cable car transport enterprise in La Paz, amongst others (see Table 3.1).

While the fact that the government was able to ensure more funding sources for the 2019 budget could be qualified as a "success", several concerns arise from the evolution of the funding structure from 2006 to 2019. The first one is associated with a problem of incentives. During the Morales administration, several state-owned enterprises were created, on the grounds that the state should be strategically positioned as a major producer. Most of these newly 
Table 3.1 Source of funding for Bono Juancito Pinto (2019)

\begin{tabular}{ll}
\hline Source of funding & Business \\
\hline YPFB & Oil company \\
COMIBOL & Mining company \\
BOA & Airline \\
DAB & Customs \\
ENTEL & Telecommunications company \\
COFADENA & Military company \\
ENDE & Electricity company \\
TAB & Air cargo company \\
VINTO & Mining company \\
EBA & Food processing company \\
Nueva EBA & Food processing company \\
SABSA & Airport administration company \\
MI TELEFÉRICO & Cable car company \\
TAM & Airline (military) \\
ABE & Aeronautics and Space agency \\
ASPB & Port management \\
BTV & TV company \\
LACTEOSBOL & Food processing company (milk) \\
EBC & Building company \\
BANCO UNIÓN & Bank \\
EMAPA & Food processing company \\
\hline
\end{tabular}

Source: Own elaboration using data from UDAPE

created enterprises ended up providing resources for the funding of Bono Juancito Pinto (among other diverse tasks). There is a general concern with the diverse burdens that these companies need to cover, given the different goals that governments assign to them, ranging from jobs creation to funding social policy (Lin et al., 1998; Shirley \& Walsh, 2000). This diversity of functions and the multiplicity of objectives for the public enterprises could be problematic from the point of view of the sustainability of the financial resources required by the social transfer.

Another source of concern related to the numerous sources of funding for the Bono Juancito Pinto is more general, related to the creation of fiscal space to gather the resources needed to cover the obligations acquired by the state. While creating enough funding (i.e., the size) is actually very important to sustain the transfer over time, a focus on quality of these resources should also be taken into account (an element of quality being how sustainable are the resources). 


\section{Bono Juana Azurduy}

The Bono Juana Azurduy (BJA) is a conditional cash transfer program introduced in 2009. The transfer beneficiaries are pregnant women and children up to two years old, conditional on the regular attendance to medical check-ups. The program's cash payments can sum up to Bs1820 (USD260) per mother/child if all the check-ups are correctly undertaken. In addition to these cash payments, the program also covers births in public hospitals.

As in the case of BJP, the source of funding for the BJA transfer was neither clearly stated from the beginning. The supreme decree establishing the transfer affirms that "according to availability, the 'Juana Azurduy" transfer will be financed with resources from a) The National Treasury; b) Donations and external/internal credits; c) Transfers from public and private entities and institutions" (Supreme Decree 066-Creation of Bono Juana $A z u r d u y)$.

In 2012, Law 211 mandated that the BJA would be financed from then on with the central bank's foreign reserves yields. Apart from the public budget, foreign reserves (FX reserves) were the other winner of the commodities' windfall, given its close relationship with exports. The export revenues are paid in dollars (or any other foreign currency), yielding an increase in FX reserves. Figure 3.6 shows the relationship between FX reserves and the international

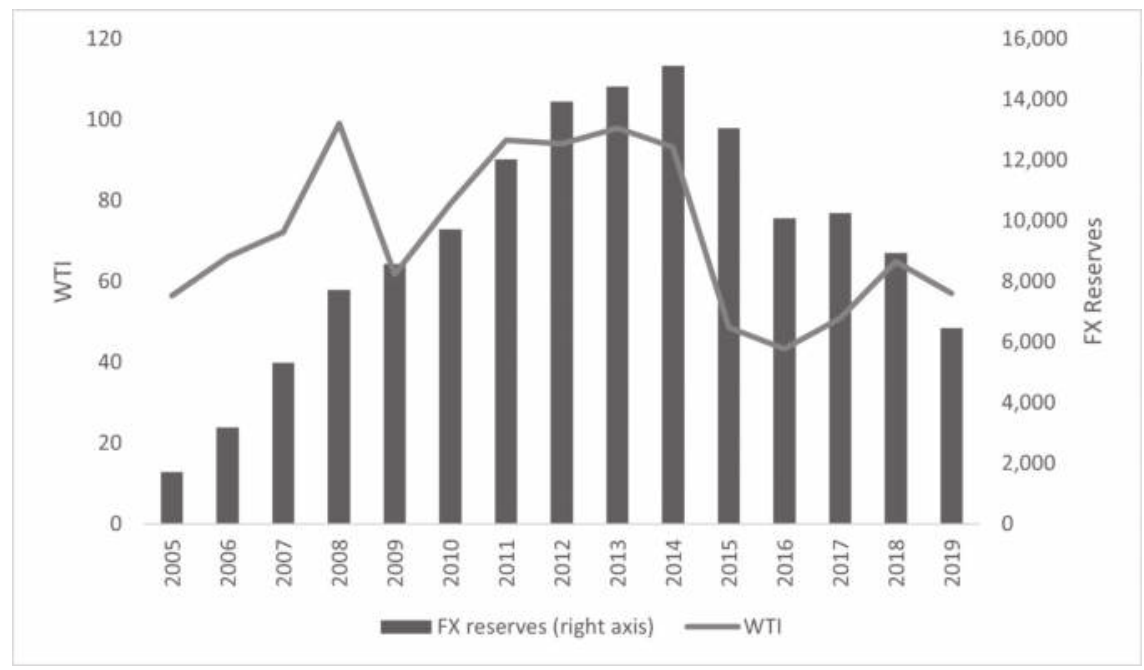

Figure 3.6 Relationship between FX reserves and WTI

Source: Own elaboration using data from UDAPE 
price of oil. We see that the relationship is positive, implying once again that the funding source of the BJA transfer is closely linked to the variations in the international prices of commodities.

Again, the high dependence on foreign revenues constitutes a potential fragility, since a change in the conditions of gas exports would put the continuity of social protection policies at risk (Monterrey, 2013). In addition, financing for social policy is not normally a core competence of a central bank, and this additional burden could in fact distort the customary objective of maintaining price level stability in the economy. As in the case of the funding of the Bono Juancito Pinto, although there have been no serious consequences so far (in the sense of suspension of payments, etc.), there is a clear problem of incentives between a central bank's traditional objectives (i.e., maintaining currency's purchasing power, financial stability, or other related) and providing funding for social policy instruments. The political and economic independence of central banks is generally understood as a desirable feature of modern monetary and financial policy (Alesina \& Summers, 1993) and a guarantee for macroeconomic stability (Grilli et al., 1991). In this sense, relying on the central bank's foreign exchange reserves for funding a social transfer program could distort the objectives of maintaining the currency power purchasing and pursuing financial stability.

\section{Conclusion}

This chapter has explored the interaction between social policy innovations, understood as a type of institutional change, and the resource boom in Bolivia during the years 2003-2014. It has been shown that this boom is related to key reforms in the natural resource sector which were introduced in Bolivia since the 1990s. These reforms paved the way for gathering more resources from the natural resource sector (mainly natural gas), which allowed the successive governments to build a social protection system reflecting the increased government fiscal revenues. This system could be conceived of as a social protection floor that acts as a citizen's dividend of the resource boom.

The importance of these social protection innovations in overcoming the high poverty and inequality rates present in the country is undeniable. Nevertheless, by linking the different cash transfers to the volatile global prices of oil and gas, an element of instability is introduced in the system. This element may potentially reduce the effects of the social protection system in the future, by limiting its capacity to provide support to those in need. As in the case of BONOSOL in the past, the instability in the sources of funding could lead in the worst scenario to a suspension in the payments of the social transfers with negative consequences for all the recipients. In the case of the Bono Juancito Pinto, such instability has already been observed. The downturn in the oil industry, with declining global prices in the sector, have pushed the government to be "creative" at the time of looking for sources of finance for the protection 
floor, skimming resources from a wide array of public companies. While some of these already confront problems of financial sustainability, converting them into sponsors of the national social programs may be a liability for their futures.

As mentioned before, the literature convincingly argues that using domestic sources for financing social protection systems is critical for their success, as is the existence of an efficient tax administration (Hujo et al., 2010). Elements of both reforms include avoiding rent-seeking behavior, as well as fiscal evasion and avoidance, which are phenomena that tend to appear especially in resource economies. Besides, applying effective taxes to income and real property would enhance the government's fiscal position. (Harris, 2013, p. 120).

In the case of Bolivia, this alternative would imply the adoption of a progressive tax reform enabling the state to raise money from its citizens to protect its citizens. For several reasons, such a comprehensive reform of the national tax system has not been on the political agenda so far. Particularly, the high degree of economic informality prevents raising revenues coming from a progressive tax (like, for example, an income tax). Also, increasing taxes is a sensible subject in Bolivia that elicits resistance from wealthy and poor sectors alike. In this sense, the use of the revenues stemming from the natural resource sector to build a social protection floor was a way to satisfy both the demands of elites as well as the necessities of the poor. However, given the instabilities arising from its design, the local mobilization of resources by means of a progressive tax reform will be an urgent task ahead.

\section{Note}

1 Chaco heroes, in reference to the war against Paraguay over control of the northern part of the Gran Chaco region (known in Spanish as Chaco Boreal) of South America, which was thought to be rich in oil.

\section{References}

Alesina, A., \& Summers, L. H. (1993). Central bank independence and macroeconomic performance: Some comparative evidence. Journal of Money, Credit and Banking, 25(2), 151-162. https://doi.org/10.2307/2077833

Amarante, V., \& Brun, M. (2018). Cash transfers in Latin America: Effects on poverty and redistribution. Economía, 19(1), 1-31. www.jstor.org/stable/90025861

Antelo, E. (2000). Políticas de estabilización y de reformas estructurales en Bolivia a partir de 1985. In L. C. Jemio \& E. Antelo (Eds.), Quince años de reformas estructurales en Bolivia: Sus impactos sobre inversión, crecimiento y equidad (pp. 15-98). Universidad Católica Boliviana San Pablo, IISEC.

Arezki, R., Dupuy, A., \& Gelb, A. (2012). Spend or send. Finance and Development, 49(4), 28-31. https://doi.org/10.5089/9781475576122.022.A011

Banco Central de Bolivia. (2019). Boletín del sector externo (No. 85). BCB.

Cechinni, S. (2019). Protección social universal en América Latina y el Caribe: Textos seleccionados 2006-2019. CEPAL. https://repositorio.cepal.org/handle/11362/44995 
Devereux, S. (2002). Social protection for the poor: Lessons learnt from recent international experience. IDS Working Paper No. 142. Sussex: Institute of Development Studies. http:// opendocs.ids.ac.uk/opendocs/bitstream/handle/20.500.12413/3907/Wp142.pdf

Ferreira, F. H. G., \& Robalino, D. (2010). Social protection in Latin America: Achievements and limitations. Policy Research Working Papers 5305. World Bank.

Gamboa, R. (2006). Evaluación de la sostenibilidad del pago del Bonosol. Revista de Análisis Económico, 21, 62-82. www.udape.gob.bo/portales_html/analisisEconomico/analisis/ vol21/Gamboa21.pdf

Grilli, V., Masciandaro, D., Tabellini, G., Malinvaud, E., \& Pagano, M. (1991). Political and monetary institutions and public financial policies in the industrial countries. Economic Policy, 6(13), 341-392.

Harris, E. (2013). Financing social protection floors: Considerations of fiscal space. International Social Security Review, 66(3-4), 111-143. https://doi.org/10.1111/issr.12021

Hujo, K., Gaia, E., \& McClanahan, S. (2010). Chapter 8: Financing social policy. In Combating poverty and inequality: Structural change, social policy and politics (pp. 207-228). UNRISD.

Instituto Nacionalde Estadística-INE. (2020). Boletínsectorial dehidrocarburos $N^{\circ} 1$. INE. www. ine.gob.bo/index.php/publicaciones/boletin-sectorial-hidrocarburos-no1-2020/

International Labour Organization-ILO. (2011). Social protection floor for a fair and inclusive globalization: Report of the Advisory Group chaired by Michelle Bachelet. ILO. www. ilo.org/wcmsp5/groups/public/-dgreports/-dcomm/-publ/documents/publication/ wcms_165750.pdf

Lin, J. Y., Cai, F., \& Li, Z. (1998). Competition, policy burdens, and state-owned enterprise reform. The American Economic Review, 88(2), 422-427. www.jstor.org/stable/116960

Loza, G. (2007). Diseño de la red integral de protección social en Bolivia. Revista de Análisis Económico, 22, 164-196. www.udape.gob.bo/portales_html/analisisEconomico/analisis/ vol22/7DRIPS.pdf

Medinaceli, M., \& Mokrani, L. (2010). Impacto de los bonos financiados con la renta petrolera. Umbrales. Revista del postgrado multidisciplinario en Ciencias del Desarrollo, 20, 223-263.

Millán, T. M., Barham, T., Macours, K., Maluccio, J. A., \& Stampini, M. (2019). Long-term impacts of conditional cash transfers: Review of the evidence. The World Bank Research Observer, 34(1), 119-159. https://doi.org/10.1093/wbro/lky005

Monterrey, J. (2013). Sistemas de protección social en América Latina y el Caribe: Estado Plurinacional de Bolivia. Documentos de Proyectos No. 553. CEPAL. http://hdl.handle. net/11362/4103

Morales, J. A. (2014). Los ingresos extraordinarios de Bolivia en el periodo 2006-2013: Una visión de conjunto. In J. A. Morales (Ed.), ¿Dónde está la plata? Los ingresos extraordinarios de la bonanza 2003-2013 (pp. 9-30). Fundación Milenio.

Müller, K. (2009). Contested universalism: FromBonosolto RentaDignidadinBolivia. International Journal of Social Welfare, 18(2), 163-172. https://doi.org/10.1111/j.1468-2397.2008.00579.x

Robles, M., Rubio, M. G., \& Stampini, M. (2019). Have cash transfers succeeded in reaching the poor in Latin America and the Caribbean? Development Policy Review, 37(2), 85-139. https://doi.org/10.1111/dpr.12365

Rodríguez Cáceres, G. (2021). ¿Prohibido envejecer en Bolivia? Desafíos del sistema integral de pensiones. In L. M. Calvo, A. Baudoin, F. Wanderley, W. Gómez, \& J. Badani (Eds.), Bolivia debate: Un futuro sustentable (pp. 18-24). UCB et al. www.ucb.edu.bo/wp-content/ uploads/2021/02/Separata_Bolivia_Debate_compressed_1.pdf\#page $=18$

Romero, F. (1988). Fondo social de emergencia, Bolivia. CEPAL. hdl.handle.net/11362/33246 
Sánchez, S., \& Velásquez, R. (2020). Situación de la renta petrolera en Bolivia. Serie de debate público, 82. Fundación Jubileo. https://jubileobolivia.org.bo/Publicaciones/ Revistas-Especializadas/Situacion-de-la-Renta-Petrolera-en-Bolivia

Shirley, M. M., \& Walsh, P. (2000). Public vs. private ownership: The current state of the debate. Policy Research Working Papers. World Bank. https://doi.org/10.1596/1813-9450-2420

Sojo, A. (2017). Protección social en América Latina: La desigualdad en el banquillo. Libros de la CEPAL, N 143 CEPAL. 


\title{
4 Growing under the shadow of oil
}

\section{Institutionalizing the mining sector in Ecuador between 2002 and 2019}

\author{
Paúl Cisneros
}

\section{Introduction}

There is now considerable evidence that under certain conditions, petroleum tends to produce adverse effects on the economic, social, and political wellbeing of a country (Ross, 2015). One particular area of concern for scholars and practitioners relates to how oil dependence influences the capacity of a state to promote economic development through competitive diversification, that is, the creation of competitive advantages in other non-extractive sectors (Auty, 1993; Gylfason, 2006). Existing research overlooks how oil dependence affects the development of institutions in other extractive sectors such as metal mining (gold, copper, zinc, among others) or gas. This chapter studies how oil dependence affected the development of the metals mining sector in Ecuador between 2002 and 2019. The interest in this issue arises from the cases of Colombia and Ecuador, where governments have unsuccessfully tried to develop the metal mining sector with the expectation of replacing oil as the primary source of state revenues, and of launching more extensive economic diversification plans (Ponce Muriel, 2012; Cisneros, 2017).

Some scholars argue that high dependence on the extraction of natural resources creates conditions that allow for and encourage the continued expansion of the extractive sector. They call this the extractive imperative (Arsel et al., 2016a). Environment and development policies are thought to reinforce extractive activities deepening and speeding up the extraction of value from nature and natural resources (Arsel et al., 2016b).

The extractive imperative thesis appears sound when extractive sectors, such as hydrocarbons, metals, or gas, are analyzed separately. The development of metal mining in Peru is a case that conforms with the extractive imperative thesis. The expansion of large-scale mining in the past two decades prompted the development of institutions that reinforce its importance for the economic development of the country (Orihuela \& Paredes, 2017). However, the original formulation of the extractive imperative thesis fails to explain why, despite the important role of the oil sector in the economy and the support given to metals mining in their development plans, Colombia and Ecuador have dramatically failed to achieve their goals in the mining sector. 
The argument put forward in this chapter is that economic dependence on the oil sector undermines some conditions necessary for the development of the metal mining sector. Specifically, the selection of appropriate policy instruments to deal with the specific needs mining. While the extractive imperative thesis only considers positive or reinforcing feedbacks between extractive sectors, this chapter studies negative feedbacks to offer a more nuanced understanding of the processes of institutional development in the extractive sector.

The main questions in this chapter are: Why did plans to develop the mining sector fail in the past decade and a half? What role does oil dependence play in the production of this outcome? The study focuses on the process of developing the capacity to promote, establish, and develop large-scale metal mining operations according to long-term plans, and with support from key actors.

The next two sections, present the background information on the case and develop the theoretical approach that underpins the empirical study. The following two sections present the methods and the results of the study. The concluding remarks brings the chapter to a close.

\section{The case}

In 2006, Rafael Correa was elected president of Ecuador with a political agenda that proposed to bring the state back to the center of public action. This plan included the direct participation of public sector organizations in oil and metal mining. During his campaign, Correa announced the use of the endowment of nonfuel mineral resources - mostly gold and copper - to close the expanding wealth gap, especially in the regions where extractive activities were taking place. The main objective of the proposed policy change was to take advantage of the unusually high commodity prices that started in 2003 by increasing state revenues received from this sector. Developing a strong metal mining sector became one of the government's top priorities. According to the government's plans, the metal mining sector had to grow quickly, and the most advanced large-scale mining projects (Mirador and Fruta del Norte) were to yield royalties as soon as 2012 and become the primary source of state revenue by 2020 .

However, by late 2018, investments in the metal mining sector only contributed to $1.61 \%$ of the GDP. It had indeed surpassed the $0.05 \%$ threshold of the 2001 and 2007 period (Ministerio de Energía y Minas, 2007, p. 11), but its contribution to the economy is still small. Authorities now expect that metal mining will amount to 4\% of GDP by 2021. Important challenges remain to achieve this goal as critical components of the sector are still largely underdeveloped. The government has kept the mining cadastre closed to new concessions and suppressed the sectoral ministry in 2018, and several strategic projects are facing local consultations seeking to ban mining in their jurisdictions. In short, the development of the metal mining sector has fallen short of the expectations set by the reformist agenda launched in 2006 .

The Ecuadorean experience under the government of Rafael Correa fits the description of the extractive imperative developed by Arsel et al. (2016a, 
2016b). The government of Rafael Correa was elected with the support of a large majority that increased as the government expanded social programs and other forms of public investments. The state recovered a central position in the extractive industries and pushed for their expansion despite opposition from former allies such as the indigenous movement and other progressive actors. Despite these characteristics, the extractive imperative in Ecuador did accelerate the expansion of the mining sector.

\section{Theoretical background}

States are organized into policy sectors to manage a wide array of public problems at the same time (Baumgartner \& Jones, 1991). In the realm of the extractive industries, it is quite common to find separate ministries to deal with nonfuel minerals and hydrocarbons. This division of labor across the public sector produces the development of specialized means to deal with the particular challenges of each sector. However, during their interventions across policy sectors, actors carry ideas about how sectoral development should take place. Ideas operate as institutions because they constrain and shape the agency of policy actors (Lascoumes \& Le Gales, 2007) by defining what is appropriate to tackle problems in specific contexts.

There are two general types of policy ideas. First, ideas may refer to principles that define how the world ought to be. Some of these ideas function as paradigms; therefore, they are hard to change via policy-oriented learning and usually require a shock to be overturned (Nohrstedt, 2005). An example of this type of idea is the role attributed to the state in the development of the extractive sectors. Two rival paradigms persist in this regard. The market-oriented paradigm limits the role of the state to set the conditions for private companies to operate. The statist paradigm promotes active and direct involvement of public sector organizations in the extractive activities.

The second type of policy ideas is more instrumental and defines how actors should translate principles into action. They also function as institutions because they incorporate notions of what is appropriate to address the problems faced by target populations, such as the use of direct coercion versus the use of informative instruments to change an actor's behavior (Howlett \& Cashore, 2009; Schneider \& Ingram, 1990; Weible \& Sabatier, 2009).

While policy instruments may be part of a developed belief system (Radae1li, 1995), they may also be discrete ideational elements that work as cognitive shortcuts adopted from other contexts (Weyland, 2006). Often, policy actors import designs from other contexts for reasons alien to the outcomes produced by such policies. Additionally, they often fail to adapt these designs to the specific characteristics of the problem at hand (Mukhtarov \& Daniell, 2016).

Given that the oil sector has dominated the Ecuadorian economy since the 1970s, it is expected that some policy ideas will constrain the selection of instruments in other sectors. Specifically, it is expected that some policy goals and instruments used in the oil sector interfered with the development of the metal 
mining sector, reducing the capacity to achieve the objectives set for the latter. The chapter assesses how objectives and tools from the oil sector influenced the political, economic, and administrative dimensions of the metal mining sector.

Working towards alignment of the political, economic, and administrative dimensions is crucial during cycles of economic expansion caused by high commodity prices in the international markets (Auty, 1993). In the political dimension, governments need to mobilize support from political and economic elites to expand and consolidate the extractive sectors. Recent studies on national political settlements highlight the importance of elite cohesion to pursue institutional development in the extractive sectors or manage the political spaces where organized civil society challenges their development (Bebbington et al., 2018, 2019).

Developing a metal mining sector requires setting economic conditions through the use of policy instruments both at the sectoral level and at the local level where companies operate. The sectoral level demands designing a flow of resources that allows companies to recover their investments and make a profit. Additionally, it requires the development of competitive advantages that help mining investments increase the production of public value (Mayorga Alba, 2009; Arzeki et al., 2011). Cheap electricity and reliable infrastructure are some elements that offer competitive advantages. Setting economic conditions at the local level means developing mechanisms to allocate benefits from mining operations to local communities to reduce the likelihood of conflict (Haslam \& Tanimoune, 2016).

Finally, developing an effective administrative system allows for better policy implementation and increases the efficacy of revenue collection and redistribution. For decision-makers, the administrative system becomes one of the most important mechanisms for materializing the benefits of extractive activities. In the mining sector, a competent administrative system requires clarity concerning who makes the rules, who administers them, and who enforces them (Natural Resource Governance Institute, 2014).

\section{Method}

The analysis presented in this chapter relies on the systematic review of policy and technical documents, and local newspaper articles published between 2002 and 2018. An original database of newspaper articles was built using two sources with national coverage: El Comercio and El Universo. These sources were reviewed to identify major policy discussions and references to the policy instruments used to develop the mining sector in the period of interest. Indepth interviews with six policy elites (including ministers, vice-ministers, and presidential or ministerial advisors) were used to expand and validate the data obtained in the document review.

\section{Results}

This section presents the interdependent development of the oil and mining sectors, highlighting the effect of policy instrument choice in the former on 


\section{Paúl Cisneros}

the latter. The presentation of the data is chronological, and it is organized into two subsections. The first one presents the general development of the two sectors until 2006. The second subsection identifies the main policy instruments adopted to develop the metal mining sector across the political, economic, and administrative dimensions.

\section{Two interdependent policy sectors: oil and mining}

Since the 1980s, Ecuador has experienced a regressive pattern of specialization driven by the increase in oil extraction. Between 2000 and 2012, the weight of oil extraction in GDP and the percentage of the total income of the nonfinancial sector that originated from oil earnings increased (Mateo \& García, 2014; Caria \& Domínguez Martín, 2015). The economic crisis of 2008 and the consequent decrease of commodity prices reduced dependence in the 2008-2009 period, but there are indications that dependence grew after 2009. During the 2002 and 2012 period, the percentage of state revenue generated from oil exports increased from 22\% to 40\% (Mateo \& García, 2014).

The mining sector has trailed behind the oil sector in terms of its contribution to GDP, with less than $1 \%$ in the average during the same period. However, the development of these sectors has been deeply intertwined since 1999 because they were regarded as the main sources of revenue to maintain and expand social programs amid a major economic crisis. They were also seen as the main sources to serve the debt assumed through the bailout received from the International Monetary Fund and the World Bank in 2000 (Ruiz Acosta \& Cisneros, 2014).

The expansion of the oil frontier in the Amazon and the attraction of investments for exploration in the mining sector were two top priorities for the government of Gustavo Noboa (2000-2003). In this line, the government passed a package of open-market reforms for both sectors in the early 2000s. These reforms allowed the construction of a second oil pipeline by a consortium of private companies, which started in 2002 (the OCP or oleoducto de crudos pesados; see Figure 4.1).

In addition, the government passed an almost entirely new set of mining regulations in early 2001, creating "the most favorable conditions for the industry in Latin America." Despite the legal overhaul and the positive effect on the business climate, low mineral prices in the international markets, mergers, acquisitions, and changes of global corporate strategies delayed the advancement of the most important prospects (Velasco, 2002, 2003). Therefore, the bulk of gold production in Ecuador was carried out by small mining cooperatives (Velasco, 2002). In 2003, the World Bank reported that the Ministry of Energy and Mines (MEM) ${ }^{2}$ had abandoned overseeing and control in the mining sector because its limited administrative capacity was devoted to processing requests for new concessions and the development of the oil sector (Cisneros \& Christel, 2014). ${ }^{3}$

By 2004, dependency on oil had deepened due to rising prices in the international markets. Despite the high rate of economic growth experienced 
Pacific Ocean

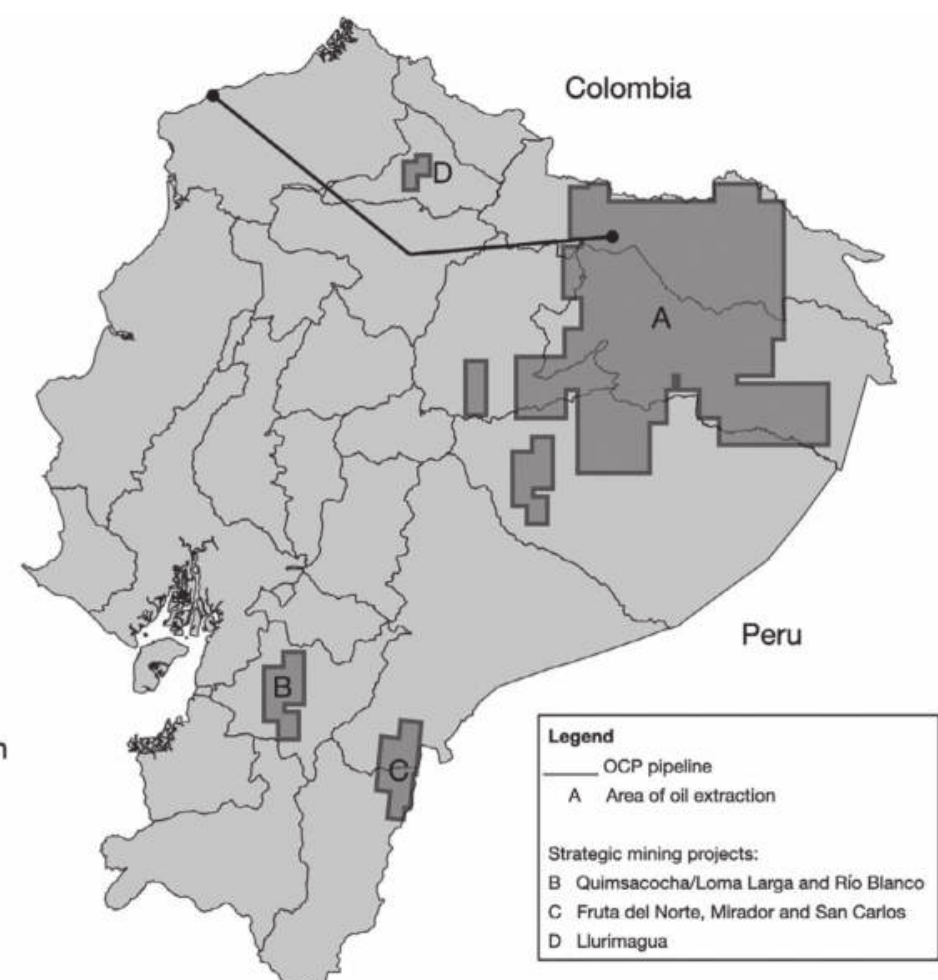

Figure 4.1 Location of oil extraction and metal mining projects in Ecuador

Source: Own elaboration

in 2004, the political landscape was deteriorating quickly. President Lucio Gutierrez (2003-2005) was ousted during social mobilizations after illegally replacing judges in the Supreme Court. Alfredo Palacio, who succeeded Gutierrez, announced a nationalistic turn in economic and oil policies to reverse the control that foreign private companies gained in the past half-decade in the production of oil and the capture of the extractive rent (Ruiz Acosta \& Iturralde, 2013). To this end, his government pushed for an amendment to the hydrocarbons law which mandated that the state should receive at least $50 \%$ of the benefits generated in the oil sector. The reform also raised the royalties paid by foreign oil companies on windfall profits (Anderson, 2009).

Palacio's plan to reform the oil sector that included a renegotiation of existing contracts with private foreign companies stalled growth of investments in the mining sector. One informant argues that "legal cases brought by the government against foreign oil companies and by foreign companies against Ecuador deterred foreign firms from investing in new exploration and development of mineral and fuel properties or from acquiring existing operations." ${ }^{4}$ 
Public protests against the exploration and development of large-scale projects increased during Palacio's government, further deterring investments (Anderson, 2007).

In 2005, numerous confrontations between activists and the military near mining sites led to the suspension of mining activities in Mirador and other large-scale projects. The government declared a halt to all mining operations for the sectoral authority to implement free, prior, and informed consultations with local communities and launched an initiative to reform the Mining Law (Ley de Minería). Palacio was unable to secure support from the National Congress to pass this reform before the end of his government.

\section{Policy goals and instruments}

With the election of Rafael Correa in 2006, the nationalistic policy agenda for the mining sector was revived. Correa was elected with support from Alianza País, a coalition of left-leaning groups and political figures who supported antiestablishment rhetoric. Correa forged alliances with former president Lucio Gutierrez's party to call for a referendum to install a Constituent Assembly. Alianza País and its allies won the elections for Assembly representatives, obtaining $70 \%$ of the seats. This result gave Correa and his political movement the power to shape the structure of the new constitution and the new regulations for oil and mining. The remainder of this subsection identifies some policy instruments used in the oil sector that were adopted in the mining sector to achieve political, economic, and administrative objectives and the outcomes of this adoption.

\section{The political dimension}

One of the main challenges for Correa's first government (2007-2011) was setting the conditions for developing a mining sector despite opposition from local communities and private companies (SENPLADES, 2007). Private companies, represented by the Mining Chamber of Ecuador (Cámara de Minería de Ecuador, CME), feared the consequences of the imminent increase of the tax burden, as occurred in the oil sector, where the state collected $99 \%$ of windfall profits. The CME warned that reintroducing royalty payments and taxes on windfall profits through a new sectoral law would discourage investments in mining (Cisneros, 2011).

On the other hand, civil society organizations demanded adequate controls over corporate behavior and open debate about the potential benefits and costs of advancing large-scale projects in certain areas. To reduce opposition from local communities, the MEM organized the so-called Mining Dialogue (Diálogo minero) in 2007. In the dialogue, companies and local communities were to define a strategy to advance several projects that had been stalled since 2005 (Ministerio de Energía y Minas, 2007). During the dialogue, civil society organizations exposed a series of administrative problems in the so-called 
strategic projects. Under pressure from the national anti-mining network or Coordinadora Nacional para la Defensa de la Vida y la Soberanía (National Coordinator for the Defense of Life and Sovereignty, CNDVS), the MEM formed tripartite technical commissions with representatives from the communities to investigate these allegations. The reports produced by the commissions documented systematic violations of administrative procedures in three projects (Mirador, Llurimagua, and Quimsacocha). Still, the government refrained from taking legal actions to avoid retaliation in international tribunals (Cisneros, 2011).

Civil society organizations decided to end their participation in the dialogue and turned to the Constituent Assembly to achieve bans on existing and new large-scale projects. Responding to this pressure, the Constituent Assembly passed the so-called Mining Mandate (Mandato Minero) or Mandate 4 in April 2008. With this decision, the Assembly ordered the government to implement a temporary moratorium on mining activities. It also ordered the suspension of exploration activities for six months or until a new Mining Law could be approved. Additionally, it mandated the government to revoke $80 \%$ of the country's mineral concessions and suspended the other 20\%. Mandate 4 extinguished 3,000 concessions where administrative requirements have not been met. Finally, the Mining Mandate halted approximately 1,200 pending requests for new concessions (Wacaster, 2010).

Correa's government used the implementation of the Mandate to generate consensus among the economic elites - the mining companies and the CME-regarding conditions for the development of the mining sector (Cisneros, 2011). To gain support for a new Mining Law, Correa eased regulations on social and environmental consultations, which legalized the continuation of the most advanced projects (Mirador, Fruta del Norte, and Quimsacocha; see Figure 4.1), even if they did not comply with Mandate 4 (see Murillo Martín \& Hurtado Caicedo, 2016).

Conflicts between mining companies and local communities increased with a partial implementation of Mandate 4. To manage these conflicts, the government adopted policy instruments used for decades in the oil industry. The government's approach relied on so-called community-relations teams, who paid community representatives to grant social licenses for companies (Narváez, 2004). An informant commented on how this approach affected the mining sector:

Despite the official announcement of a new approach to managing social conflicts, it [corporate-community relations] was seen as something that could be managed based on the experience developed in the oil sector. The government thought they could assemble a team to negotiate minor investments in the communities, somehow paid for by companies that were not yet making any money. Such community-relations teams managed intense conflicts in the oil sector, which drew permanent political attention from national authorities, and had money. However, these teams were not prepared to build long-term relationships that could last during 30 to 40 
years of mineral extraction.... [T] hey had no resources to offer. Now we see the effects of that lack of true consensus-building, not only in projects but for the development of the industry itself. ${ }^{5}$

The legacy of the policy instruments imported from the oil sector to deal with socio-environmental conflicts constrained the chances of Correa's successor, Lenin Moreno (2017-2021), to push the development of the mining sector forwards. By mid-2019, several strategic projects (Río Blanco, Loma Larga, and Llurimagua) were under heavy pressure by local communities and antimining organizations that demanded consultations in their jurisdictions. These demands were voiced in parallel to legal processes to stop mining projects due to a lack of compliance with social and environmental regulations. The town of Pacto near the capital city of Quito organized the first consultation in 2015, in reaction to the presence of a project owned by the National Mining Company (Empresa Nacional Minera, ENAMI-EP) (Ávila, 2015). Nearly 67\% of the population participated, and 97\% rejected ENAMI's project. In August 2018, the provincial court of Azuay ratified the suspension of the Río Blanco project in Azuay after determining the company had not carried out a process of free, prior, and informed consultation.

\section{The economic dimension}

In 2007, Correa's government introduced reforms that allocated 99\% of windfall profits from the oil sector to the government. Additionally, the government introduced a new contractual form by which the state pays private companies for specific services (exploration, extraction, and commercialization). The refusal of private companies to accept the terms laid out by the government prompted a reduction of the tax on windfall profits to $70 \%$ through the Law for Tax Equity (Ley de Equidad Tributaria) in mid-2008 (Mateo \& García, 2014). The legal actions launched by private companies dragged the country through a lengthy five-year process to renegotiate existing contracts (Wacaster, 2011).

Despite this setback to the implementation of the nationalistic approach to natural resource governance, the same policy instruments were adopted for the metal mining sector a year later. In a context of increasing social spending and high metal prices, the government announced the reintroduction of royalties for mining operations, and the adoption of windfall taxes despite opposition by the mining guild. As one informant commented:

At the time, the government did not understand the nature and the magnitude of investments required in the mining sector before sales produce profits. The idea they had that granting a mining concession means that mineral production starts soon after, as it more or less happens with oil, had people believing that the most advanced projects (Mirador and Fruta del Norte) would start paying royalties in a couple of years. That is not how the mining industry works. Companies have to invest large amounts of money, 
which has to be recovered within the first years of production, and only from then on is there a profit that could be taxed by the state. ${ }^{6}$

This decision stalled the flow of new investments to the metal mining sector between 2008 and 2010. Moreover, the owners of the most advanced projects sold part or the entirety of their assets in the country. In 2008, Aurelian Resources sold Fruta del Norte to Kinross Gold, and Corriente Resources sold Mirador to a conglomerate of Chinese mining companies. Policy actors fully grasped the consequences of the decisions made regarding the tax regime when Kinross Gold, owner of the Fruta del Norte project, announced it would sell the majority of its interests in mid-2013. At the time, Kinross Gold CEO said, "we have been at the negotiating table for two years ... and sometimes the best deal is the one you don't sign, and we believe that's the case here" (El Telégrafo, 2013). The exit of Kinross from one of the most significant gold discoveries of the decade marked

the moment when government authorities perceived mining as fundamentally different from oil. It also made it clear that other countries in the region were still operating in a completely different scenario, one similar to the regulations dismantled in 2008 by the new constitution. Moreover, for some people in the government, the limits of the nationalistic project became apparent, and more so considering the recent exponential growth of mining in Peru and Chile. ${ }^{7}$

Between 2007 and 2012, the government allocated a budget to develop competitive advantages that would serve to attract investments to the mining sector. It invested nearly US $\$ 16$ billion or $4 \%$ of the annual GDP on infrastructure for the strategic sectors. ${ }^{8}$ Among these, investments in renewable energy (hydropower) and roads were the most considerable, receiving US $\$ 4.5$ billion and US $\$ 6$ billion, respectively (Caria \& Domínguez Martín, 2015). According to the objectives laid out in the 2009-2013 National Development Plan (Plan Nacional para el Buen Vivir), the remainder would provide cheap energy to reduce the reliance of the economy on the primary sector. Caria and Domínguez Martín show that between 2009 and 2014, the Ecuadorian economy did not show signs of diversification or improved systemic productivity (Caria \& Domínguez Martín, 2015, pp. 53-54).

On the other hand, when the government refrained from adopting instruments from the oil sector, it produced some positive outcomes for the development of the mining sector. This is apparent in the case of redistributing revenue to local communities. Whereas in the oil sector this redistribution was largely in the hands of oil companies, Correa's government made use of various mechanisms to boost public investment in mining regions. In 2010, it reformed the General Regulations of the Mining Law (Reglamento General de la Ley de Minería) to define the percentage of the royalties to be paid by mining companies and the criteria for their allocation to the local governments 
(municipalities and parishes) where extraction takes place. The government also created the public company Strategic Ecuador (Ecuador Estratégico, EE) in 2011, under the Coordinating Ministry for Strategic Sectors (Ministerio Coordinador de los Sectores Estratégicos, MICSE). ${ }^{9}$ EE's mission was to invest resources from royalty payments as part of local development plans or through programs and projects defined at the national level. These decisions reduced opposition to mining in certain areas, in particular near the Fruta del Norte and Mirador projects. ${ }^{10}$

Regarding the taxation of private mining companies, the policies adopted by the government diverged from those in use in the oil sector. Not all mining companies had made significant discoveries that allowed them the cash flow to commit to paying anticipated royalties to the government. Therefore, the mining guild continued lobbying to reform the tax regime. By the government's initiative, in late 2016, the National Assembly approved the Ley de Plusvalía (Law on Capital Gains) that contained a mechanism to defer tax payments for four years after mining companies recovered their capital investments. The mining minister expected these reforms to bring nearly US $\$ 4.6$ billion until 2021 to help the Río Blanco, Mirador, and Fruta del Norte begin with production. ${ }^{11}$ Aided by the influx of new investments, the latter two projects started production in 2019.

\section{The administrative dimension}

Despite the clear policy objective of extracting metals to increase state revenue and social spending, the required changes in administration came slowly. To begin with the development of a new institutional architecture for the strategic sectors, Correa's government split the MEM into two agencies in 2007. One agency received the competencies on electricity and renewable energy (the Ministerio de Electricidad y Energías Renovables, Ministry for Electricity and Renewable Energies), while the other became the Ministry of Mines and Petroleum (Ministerio de Minas y Petróleos, MMP). Within the latter, the mining sector was headed by the Vice Ministry of Mines (Viceministerio de Minas). Still, the administrative reform of the mining sector faced the challenge of structuring a competent administrative system. At the time, "the mining cadastre, which is arguably the administrative heart of the mining industry, existed in an Excel spreadsheet without any proper securities or control". ${ }^{12}$ To make matters worse, the intervention of the Constituent Assembly over existing concessions delayed initiatives to improve the administrative capacity until 2009.

The process of institutional development resumed when the Legislative Commission, ${ }^{13}$ where Alianza País still held the majority, approved the Mining Law in early 2009. The Law defines the structure of the mining sector with the MMP as a sectoral authority, and two ascribed agencies, one for regulation (ARCOM), and one for geological research (INIGEMM), and a dependent national mining company, ENAMI-EP. In this context, the government changed the name of the MMP to the Ministry of Nonrenewable Natural 
Resources (Ministerio de Recursos Naturales no Renovables, MRNNR). This organization maintained the responsibility for the exploitation of nonrenewable natural resources, policy management, and research and development. ARCOM received the task of updating and managing the mining cadastre, while the Vice Ministry of Mines held the responsibility of designing sectoral policy.

Before the end of the year, the Vice Ministry of Mines issued new environmental regulations, as well as rules for small and artisanal mining, and the General Regulations of the Mining Law. However, by the end of the year, there was still uncertainty among private companies regarding the general conditions for the administrative management of mining in Ecuador. Concerns were related to how strictly the new legislation would be applied, and the extent to which foreign investment would be affected by the new rules (Wacaster, 2011, p. 1).

One of the critical amendments related to demands made by private companies and the CME was the creation of a specialized and competent authority, a proper ministry of mines. Some key actors from within the government also supported this idea:

We at the Coordinating Ministry of Strategic Sectors (MICSE) were convinced that it was necessary to separate mining and oil. Due to the nature of the oil sector, you cannot divide your attention between the two. . . One of the main reasons to demand a different institution is that in practice, the minister will always prioritize oil due to its current economic importance. . . Even within the MRNNR, there was support for the break-up. ${ }^{14}$

In 2015, Correa admitted that developing the mining sector required a specialized ministry. He stated that "currently, as a Vice Ministry within the Ministry of Nonrenewable Resources, mining has been absorbed by oil. . . . There has not been enough support or resources for the mining sector" (El Telégrafo, 2015). Therefore, he created the Ministry of Mines in 2015. Now that mobilizing authority resources had pushed the mining sector to the forefront, the challenge was to ensure that treasury resources followed. However, due to the economic crisis caused by the reduction in oil prices since 2014 ,

the Ministry of Finance assigned only half the money and resources required for the new Ministry of Mines, and ARCOM, which is a regulatory agency, retained the most important piece of mining policy: the management of the mining cadastre. This decision split policy authority in two. ${ }^{15}$

Another critical piece of the institutional architecture for the mining sector mandated by the 2009 law was the creation of a state-owned company. This organizational model was adopted from the oil sector even though the two state-owned oil companies had performed poorly in previous years. On December 31, 2009, the government created ENAMI-EP with preferential 
access to mineral resources to be developed in association with other public companies, and only as an exception with private partners (Wacaster, 2011, p. 1). Therefore, the effect of the creation of ENAMI-EP over the operations of private mining companies was unclear. Several informants acknowledge that ENAMI-EP emerged mostly from the dominant ideas in the oil sector:

ENAMI-EP . . . is Correa's pipedream. His nationalist ideology made him emulate the system we had in place for hydrocarbons. In principle, it makes sense that operating directly through a public company, the state could make more money, as CODELCO in Chile does. However, in the mining world, profitable public companies are rare. The private sector drives the mining industry because the risk of investing and not finding anything is high, and because of the long-term horizons of extraction that are incompatible with most political horizons. Moreover, having a public company that assumes risks in exploration is incompatible with our system of control of public resources, because not generating revenue is punished by the Comptroller General's Office, it is just not a viable option. ${ }^{16}$

Between 2010 and 2019, ENAMI-EP did not produce a single project or partnership with a clear outcome for large-scale projects.

The process of granting new concessions had also been influenced by policy ideas and instruments used in the oil sector:

Both the state and society were used to the so-called oil rounds. It was what we knew how to do. Therefore, the local professionals who are just learning about mining steered us (the MEM) towards the mechanisms used in the oil sector. We decided to hire a company with global experience to look at the factors promoting competitiveness in the region. They suggested we adopt a Swiss challenge to grant concessions. Help from outside actors was key to create something viable. ${ }^{17}$

The adoption of this mechanism produced some positive outcomes for the mining sector. With this novel instrument, the government granted a total of 235 new concessions, and between 2016 and 2017, Ecuador received roughly US\$1.153 billion in investment.

The economic crisis of late 2015 and early 2016, and the austerity measures deployed by President Moreno between 2017 and 2019, slowed down the consolidation of the institutional architecture described previously. ENAMIEP's budget was slashed. As one informant notices: "It was hard to justify the existence of a national company that at some point had made some progress towards working with small mining cooperatives but had not developed major projects yet." 18

Additionally, ENAMI was not able to manage the social conflicts created by private companies in previous years (Avci, 2015). The conflicts in the region of Intag dragged on and affected a copper-molybdenum project known as 
Llurimagua, where ENAMI-EP partnered with CODELCO in 2011. The conflict escalated in September 2014 when the government released a hastily completed 1,000-page environmental impact assessment for public review (Wacaster, 2017, p. 2), which, according to local organizations, did not comply with existing regulations for environmental assessments. The Office of the Comptroller General (Contraloría General del Estado) verified these failures in a report released in 2019 (Redacción La Hora.EC, 2019), and the project came to a halt.

As part of the austerity measures launched in 2017, President Moreno announced a merger between the ministries of Electricity, Mines, and Hydrocarbons. The argument presented by the government for this decision was that creating a strong super-ministry (the Ministry of Nonrenewable Resources) would increase the government's capability for pushing the new long-term policies designed for the energy, mining, and oil sectors. With this new architecture in place by early 2018, the sectoral authority of the mining sector was again the Vice Ministry of Mines, under the Ministry of Energy and Nonrenewable Resources. The president appointed an expert in hydrocarbons as head of this new Vice Ministry. Although this re-organization went against the process of learning experienced between 2008 and 2015 and historical demand of the mining guild for having the support of a specialized authority, the biggest concern for mining companies at the time related to the proliferation of local consultations to stop large-scale projects as discussed earlier.

\section{Concluding remarks}

The literature on the resource curse shows several adverse effects or negative feedbacks that occur with the development of the extractive sectors over the rest of the economy. The Dutch disease and middle-income traps are some of these adverse effects. More recent discussions on the extractive imperative propose that the growth of extractive activities generate conditions for their continuous expansion. However, scholars have said less about the negative feedbacks caused by one extractive sector on the development of another. The aim of this chapter was to expand the current discussion of the potential negative effects of resource dependence on institutional development.

To this end, this chapter studied some negative feedbacks created by the dynamics of the oil sector on the development of the mining sector in Ecuador along political, economic, and administrative dimensions. The empirical findings show that, between 2006 and 2019, the adoption of policy instruments used in the oil sector constrained the development of the mining sector because they were inconsistent with the objective conditions existing in the latter.

Fighting this form of cross-contamination between policy sectors is a challenging task. Policy-makers, as well as other actors, make sense of the world through existing policy ideas and the instruments they know best. Often, as shown in this chapter, changing existing ideas on how the mining sector should develop is the greatest barrier for choosing adequate instruments to achieve 
desired goals. However, this problem may be harder to tackle in countries like Ecuador, where decision-making is so concentrated in the figure of the president, and a pluralistic selection of policy instruments is difficult to achieve. Countries where industry actors and civil society organizations have greater legitimacy in the policymaking process may see reduced negative effects of oil dependence on the development mining sector.

Findings also show that learning is still possible under the extractive imperative. Several policy instruments were chosen that departed from what had been previously used in the oil sector and helped the government achieve some policy goals. Future research should look comparatively at the performance of policy designs employed to develop the mining sector in countries with greater and milder economic dependence on natural resources. Pursuing this line of inquiry will help scholars gain a better understanding of the political, economic, and administrative conditions that influence the adoption of policy ideas and instruments. This would add another layer of complexity to the phenomenon of the resource curse, one that uncovers important institutional implications.

\section{Notes}

1 Interview with former president of the Mining Chamber of Ecuador, Quito, August 20, 2020.

2 At the time, the Ministry of Energy and Mines (Ministerio de Energía y Minas, MEM) was the national authority for oil and mining sectors. The Undersecretary of Mines (Subsecretaría de Minas) was the national authority for the mining sector.

3 Since 1997, when environmental decentralization was adopted, the MEM was also in charge of approving environmental impact assessments, coordinating with the Ministry of the Environment, processing annual follow-up environmental reports, enforcing environmental regulations, and overseeing negotiations between mining companies and local communities.

4 Interview with former president of the Mining Chamber of Ecuador, Quito, August 20, 2020.

5 Interview with former Undersecretary of Mines, Quito, February 7, 2019.

6 Interview with former Vice Minister of Mines, February 15, Quito, 2019.

7 Interview with former Undersecretary of Mines, Quito, February 7, 2019.

8 The 2008 constitution defines the strategic sectors as those that decisively influence the economic, social, political, and environmental life of the country. Among others, the list of strategic sectors includes energy and nonrenewable natural resources.

9 The democratic reform of the state launched by Correa's government in 2007 defined a level of intersectoral coordination headed by Coordinating Ministries, of which seven were created. These ministries presided over the so-called sectoral councils. The Coordinating Ministry for Strategic Sectors (Ministerio Coordinador de los Sectores Estratégicos, MICSE) presided the sectoral council for strategic sectors that by 2017 included the Ministry of Hydrocarbons (Ministerio de Hidrocarburos), the Ministry of Mines (Ministerio de Minas), the Ministry of the Environment (Ministerio del Ambiente), and the Secretariat for Water (Secretaría del Agua). MICSE was suppressed in 2017 by president Moreno within the implementation of austerity measures needed to access loans from the World Bank and other international lenders.

10 It is worth noting that the government also increased the criminalization of protest as a means to contain opposition from organized civil society (see FIDH, 2015). 
11 See Redaccción Plan V (2017). In February 2018 the Law of Capital Gains was repealed in a national referendum.

12 Interview with former Undersecretary of Mines, Quito, February 7, 2019.

13 When the period of the Constituent Assembly ended in July 2008, representatives were appointed to the Legislative Commission, which was later replaced by the National Assembly in 2009.

14 Interview with former Vice Minister of Mines, Quito, February 15, 2019.

15 Interview with former Vice Minister of Mines, Quito, February 15, 2019.

16 Interview with former Vice Minister of Mines, Quito, February 15, 2019.

17 Interview with former Undersecretary of Mines, Quito, February 2019.

18 Interview with former president of the Mining Chamber of Ecuador, Quito, August 20, 2020.

\section{References}

Acosta, M. R., \& Iturralde, P. (2013). La alquimia de la riqueza. Estado, petróleo y patrón de acumulación en Ecuador. Centro de Derechos Económicos y Sociales.

Anderson, S. T. (2007). The mineral industry of Ecuador in 2005. United States Geological Service. https://s3-us-west-2.amazonaws.com/prd-wret/assets/palladium/production/ mineral-pubs/country/2005/ecmyb05.pdf

Anderson, S. T. (2009). The Mineral Industry of Ecuador in 2006. United States Geological Service. https://s3-us-west-2.amazonaws.com/prd-wret/assets/palladium/production/ mineral-pubs/country/2006/myb3-2006-ec.pdf

Arsel, M., Hogenboom, B., \& Pellegrini, L. (2016a). The extractive imperative in Latin America. The Extractive Industries and Society, 3(4), 880-887. https://doi.org/10.1016/j. exis.2016.10.014

Arsel, M., Hogenboom, B., \& Pellegrini, L. (2016b). The extractive imperative and the boom in environmental conflicts at the end of the progressive cycle in Latin America. The Extractive Industries and Society, 3(4), 877-879. https://doi.org/10.1016/j.exis.2016.10.013

Arzeki, R., Gylfason, T., \& Sy, A. (Eds.). (2011). Beyond the curse. IMF. notendur.hi.is/ gylfason/Beyond_the_Curse_Arezki_Gylfason_Sy.pdf

Auty, R. M. (1993). Sustaining development in mineral economies: The resource curse thesis. Routledge.

Avci, D. (2015). Mining conflicts and transformative politics: A comparison of Intag (Ecuador) and Mount Ida (Turkey) environmental struggles. Geoforum, 84, 316-325. https:// doi.org/10.1016/j.geoforum.2015.07.013

Ávila, T. (2015, April 1). Yo soy de Pacto y no quiero minería. Plan V. www.planv.com.ec/ideas/ ideas/yo-soy-pacto-y-no-quiero-mineria

Baumgartner, F. R., \& Jones, B. D. (1991). Agenda dynamics and policy subsystems. The Journal of Politics, 53(4), 1044-1074. https://doi.org/10.2307/2131866

Bebbington, A., Abdulai, A.-G., Humphreys, D., Hinfelaar, M., \& Sanborn, C. (2018). Governing extractive industries. Oxford University Press.

Bebbington, A., Fash, B., \& Rogan, J. (2019). Socio-environmental conflict, political settlements, and mining governance: A cross-border comparison, El Salvador, and Honduras. Latin American Perspectives, 46(2), 84-106. https://doi.org/10.1177\%2F0094582X18813567

Caria, S., \& Domínguez Martín, R. (2015). Estructura productiva primario-exportadora y Buen Vivir en Ecuador, 2009-2014. Revista Internacional de Cooperación y Desarrollo, 2(1), 37-64. hdl.handle.net/10902/9782

Cisneros, P. (2011). ¿Cómo se construye la sustentabilidad ambiental?: Análisis de experiencias conflictivas de la industria minera en el Ecuador [Tesis doctoral]. FLACSO. hdl.handle. net/10469/5707 
Cisneros, P. (2017). ¿Por qué no avanza la megaminería en el Ecuador? Un análisis de las disputas por la política pública en Cuenca. In L. Bottar \& M. Solá Álvarez (Eds.), Agua y megaproyectos en América Latina (pp. 57-84). Ediciones UNGS.

Cisneros, P., \& Christel, L. (2014). The democracy deficit of corporate social responsibility in post-neoliberal times: An analysis of the Argentinian and Ecuadorian experiences. Journal of Cleaner Production, 84(1), 174-182. https://doi.org/10.1016/j.jclepro.2014.03.032

El Telégrafo. (2013, June 11). Kinross Gold abandons Ecuadors largest untapped gold deposit. www.eltelegrafo.com.ec/noticias/english/1/kinross-gold-abandons-ecuador-s-largestuntapped-gold-deposit

El Telégrafo. (2015, February 13). Nuevo Ministerio de Minería se crea por Decreto Ejecutivo. www.eltelegrafo.com.ec/noticias/politica/3/nuevo-ministerio-de-minas-se-crea-pordecreto-ejecutivo

FIDH. (2015). Criminalización de la protesta social frente a proyectos extractivos en Ecuador. Misión Internacional de Investigación. INREDH/FIDH. www.fidh.org/IMG/pdf/equateur666espagn2015hd_1_.pdf

Gylfason, T. (2006). Natural resources and economic growth from dependence to diversification. In H. Broadman, T. Paas, \& P. J. Welfens (Eds.), Economic liberalization and policy integration: Options for Eastern Europe and Russia (pp. 201-231). Springer-Verlag. https:// doi.org/10.1007/3-540-31183-1

Haslam, P. A., \& Tanimoune, N. A. (2016). The Determinants of social conflict in the Latin American mining sector: New Evidence with Quantitative Data. World Development, 78, 401-419. https://doi.org/10.1016/j.worlddev.2015.10.020

Howlett, M., \& Cashore, B. (2009). The dependent variable problem in the study of policy change: Understanding policy change as a methodological problem. Journal of Comparative Policy Analysis: Research and Practice, 11(1), 33-46. https://doi.org/10.1080/13876980802648144

Lascoumes, P., \& Le Gales, P. (2007). Introduction: Understanding public policy through its instruments - from the nature of instruments to the sociology of public policy instrumentation. Governance, 20(1), 1-21. https://doi.org/10.1111/j.1468-0491.2007.00342.x

Mateo, J. P., \& García, S. (2014). El sector petrolero en Ecuador. 2000-2010. Problemas del desarrollo, 45(177), 113-139. www.scielo.org.mx/pdf/prode/v45n177/v45n177a6.pdf

Mayorga Alba, E. (2009). Extractive industries value chain: A comprehensive integrated approach to developing extractive industries. Africa Working Paper Series No. 125. World Bank. hdl.handle.net/10986/18400

Ministerio de Energía y Minas. (2007). In El ABC de la minería en el Ecuador. Ministerio de Energía y Minas. es.slideshare.net/CDESecuador/abc-de-la-mineria

Mukhtarov, F., \& Daniell, K. A. (2016). Transfer, diffusion, adaptation, and translation of water policy models. In K. Conca \& E. Weinthal (Eds.), The Oxford handbook of water politics and policy (pp. 1-29). https://doi.org/10.1093/oxfordhb/9780199335084.013.30

Murillo Martín, D., \& Hurtado Caicedo, F. (2016). Incumplimiento del mandato minero en proyectos mineros del sur de Ecuador. CEDHU. repositorio.dpe.gob.ec/bitstream/39000/2537/1/ PE-029-DPE-2020.pdf

Narváez, I. (2004). Metodología de relacionamiento comuniario no ortodoxas: análisis politico para abordarlas. In G. Fontaine (Ed.), Petróleo y desarrollo sostenible en Ecuador: Las apuestas (pp. 75-90). FLACSO Ecuador.

Natural Resource Governance Institute. (2014). Natural resource charter (2nd ed.). NRGI. resourcegovernance.org/sites/default/files/NRCJ1193_natural_resource_charter_19.6.14.pdf

Nohrstedt, D. (2005). External shocks and policy change: Three-mile island and Swedish nuclear energy policy. Journal of European Public Policy, 12(6), 1041-1059. https://doi. org/10.1080/13501760500270729 
Orihuela, J. C., \& Paredes, M. (2017). Fragmented layering: Building a green state for mining in Peru. In E. Dargent, J. C. Orihuela, M. Paredes, \& M. E. Ulfe (Eds.), Resource booms and institutional pathways (pp. 97-118). Palgrave. https://doi.org/10.1007/978-3-319-53532-6

Ponce Muriel, Á. (2012). ¿Cuál locomotora?: El desalentador panorama de la minería en Colombia. Random House Mondadori.

Radaelli, C. M. (1995). The role of knowledge in the policy process. Journal of European Public Policy, 2(2), 159-183. https://doi.org/10.1080/13501769508406981

Redacción La Hora.EC. (2019, January 28). Proyecto minero Llurimagua bajo la lupa de la Contraloría. OCMAL. www.ocmal.org/proyecto-minero-llurimagua-bajo-la-lupa-de-la-contraloria/

Redacción Plan V. (2017, October 17). Los agujeros del proyecto minero Fruta del Norte. Plan V. www.planv.com.ec/historias/sociedad/agujeros-del-proyecto-minero-fruta-del-norte

Ross, M. L. (2015). What have we learned about the resource curse? Annual Review of Political Science, 18, 239-259. https://doi.org/10.1146/annurev-polisci-052213-040359

Ruiz Acosta, M. A., \& Cisneros, P. (2014). Crisis de hegemonía y recomposición del pacto estatal ecuatoriano, 1990-2008. In R. Echavarría (Ed.), Pugna de poderes, crisis orgánica e independencia judicial (pp. 61-87). Instituto de Altos Estudios Nacionales.

Schneider, A., \& Ingram, H. (1990). Behavioral assumptions of policy tools. The Journal of Politics, 52(2), 510-529. https://doi.org/10.2307/2131904

SENPLADES. (2007). Plan Nacional de Desarrollo 2007-2010. Gobierno Nacional de la República del Ecuador. www.planificacion.gob.ec/wp-content/uploads/downloads/2013/09/Plan-Nacional-Desarrollo-2007-2010.pdf

Velasco, P. (2002). The mineral industry of Ecuador in 2000. United States Geological Service. s3-us-west-2.amazonaws.com/prd-wret/assets/palladium/production/mineral-pubs/ country/2002/ecmyb02.pdf

Velasco, P. (2003). The mineral industry of Ecuador in 2001. United States Geological Service. https://s3-us-west-2.amazonaws.com/prd-wret/assets/palladium/production/mineralpubs/country/2000/9511000.pdf

Wacaster, S. (2010). The mineral industry of Ecuador in 2008. United States Geological Service. https://s3-us-west-2.amazonaws.com/prd-wret/assets/palladium/production/mineralpubs/country/2008/myb3-2008-ec.pdf

Wacaster, S. (2011). The mineral industry of Ecuador in 2009. United States Geological Service. https://s3-us-west-2.amazonaws.com/prd-wret/assets/palladium/production/mineralpubs/country/2009/myb3-2009-ec.pdf

Wacaster, S. (2017). The mineral industry of Ecuador in 2014. United States Geological Service. https://s3-us-west-2.amazonaws.com/prd-wret/assets/palladium/production/mineralpubs/country/2014/myb3-2014-ec.pdf

Weible, C. M., \& Sabatier, P. A. (2009). Coalitions, science, and belief change: Comparing adversarial and collaborative policy subsystems. Policy Studies Journal, 37(2), 195-212. https://doi.org/10.1111/j.1541-0072.2009.00310.x

Weyland, K. (2006). Bounded rationality and policy diffusion: Social sector reform in Latin America. Princeton University Press. 


\title{
5 Hybrid institutions \\ Institutionalizing practices in the context of extractive expansion
}

\author{
Gerardo Damonte
}

\section{Introduction}

Since the 1990s, for more than two decades, extractive activities such as smallscale mining and agribusinesses have flourished in Peru under governments that were anxiously looking for the unexpected benefits offered by the prosperous commodity world market. During this cycle, extractive companies, such as mining and agro-export companies as well as small-scale miners, increased their number, territorial presence, and political importance. The extractive boom intensified extractive activities and pushed forward the extractive frontiers, generating the need for rules and procedures to facilitate, organize, and contest extractive activities. Since the state was not able to regulate such activities, old and new extractive practices flourished following state, corporate, and/or culturally embedded institutional frameworks.

Some of these practices were gradually institutionalized in interplay with new state norms, corporate practices, and/or culturally legitimated local conventions. Other extractive rules and procedures emerged from formal or informal institutional arrangements between state, private, and local actors. In this context, state laws, corporate norms, and local rules complemented, conflicted, and intertwined, constituting in some cases hybrid institutional entanglements, that is, rules and procedures that partially respond to both formal and informal institutional frameworks.

How do practices become institutionalized as hybrid entanglements in the context of extractive expansion? This article aims to respond to this question by presenting, defining, and analyzing specific cases of institutionalization of local practices that have flourished in the context of extractive boom as hybrid institutional entanglements: agribusiness companies' groundwater extraction in the Ica Valley and small-scale miners' access to gold alluvial deposits in the Peruvian Amazonia. These institutionalized practices are good examples of how the processes of institutional hybridization unfold in places where state governance is seen as limited or became hybridized (Risse, 2011; Li, 2005), places that can be found in all regions in the world.

The article argues that hybrid entanglements are produced when governments seek to regulate local practices and social actors consciously follow both 
formal and informal frameworks in processes of institutional hybridization when their practices became neither completely formal nor completely informal institutions. Moreover, it argues that the type of relationship established by specific social groups with state authority, such as processes of state capture and resistance, adaptation, or subjection to the state, shapes the generation of different forms of institutional entanglements.

This article draws on both primary and secondary data. Primary data has been collected between 2013 and 2018 in two research projects conducted by the author: one on conflicts in small-scale mining in the Amazon basin and another on the role of state policies in scenarios of water scarcity in Ica. In both projects, primary data has been collected through qualitative and ethnographic methods and instruments such as in-depth interviews and non-participatory observation. The systematization of secondary data is drawn from, among others, academic articles, state, and other public reports, maps, and datasets.

The text is divided into three sections preceded by this introduction. The first section presents the theoretical framework and key concepts used for the analysis. The second section analyzes the institutionalization of agribusiness' groundwater extraction in Ica and small-scale miners' access to alluvial gold deposits in the Amazonia as examples of hybrid institutional entanglements. Finally, the most important points of the argument presented as concluding remarks are highlighted.

\section{Conceptual framework}

Institutions are commonly defined as a set of persistent rules and procedures that structure, or shape, political and socioeconomic relationships, as well as the interactions between individuals and the social groups that make up society (Leftwich, 2006). Moreover, institutions are generally classified into two groups: formal and informal (North, 1990). Helmke and Levitsky (2004) assert that the former is understood in terms of rules that are arranged, transmitted, and reproduced through channels recognized as official, while the latter originate and reproduce in unofficial domains. For the authors, an institution that is formal implies that the rules are formally established and that infraction of such rules has sanctions prescribed by an authority constituted in a code. Informal institutions also prescribe appropriate behavior and sanctions; however, these are generated in the non-formal areas of collective action and can be explicit or not.

The literature on institutions follows a top-down approach when institutional analyses are driven from a legalist or state view, and informal institutions are thereby mostly seen as marginal or complementary to formal forms of government. Thus, the persistence and reproduction of informal institutions are perceived as indication of limited governance (Risse, 2011; Helmke \& Levitsky, 2004). Another common view is to see informal institutions circumscribed to the realm of traditional cultures (North, 1990). However, the simple association of informality with the realm of tradition runs the risk of taking informal institutions as a-historical presuppositions or as part of a static cultural essence 
(Helmke \& Levitsky, 2004, p. 727). Several studies have shown that informal institutions are not marginal, but constitutive to governance schemes and even are inherent to effective forms of governance in many parts of the world (Boege, 2017; Sindzingre, 2006).

Governance schemes are driven by social actors vis-à-vis changing formal and informal domains. Institutions are institutionalized practices performed and legitimated by social actors. Social actors' institutionalizing practices may follow formal frameworks established by the state or corporate powers recognized by the state (Ferguson, 2005) or informal frameworks such as culturally founded rules that are not recognized or regulated by the state or corporate powers. In addition, the formal domains are dynamic; changes in formal frameworks can formalize or forbid long standing informal institutions, transforming them into formal institutions or making them illegal, respectively. Likewise, and against the erroneous perception that they originate from an immovable cultural substrate, informal institutions, like formal ones, are in constant transformation, and one of the main incentives they have to do so is the presence of changes in the formal institutional environment (Helmke \& Levitsky, 2004, p. 731).

In many cases, social actors combine formal and informal frameworks while institutionalizing practices. As Olivier de Sardan (2013, p. 288) asserts, it is more productive to think of institutions as mechanisms for coordinating collective action rather than abstract structures. The institutions that regulate collective action are, in this way, part of a disorderly process and without fixed assembly direction made by individuals within the limits of their circumstances (Cleaver, 2002, p. 17). These are not defined a priori by a set of necessary, specific, and sufficient forms and functions (Sindzingre, 2006, p. 70) but are continuously transformed by the combination of forms of authority, cooperation, and behaviors perceived as more credible or effective than others.

Some authors regarding the way in which formal and informal institutions are intertwined have used the state strength/weakness or presence/absence as possible values for this kind of explanatory variable. Drawn in this framework, the ability of states to provide public services and maintain internal security is evaluated by international organizations, classifying them in an ascending line that goes from failed or collapsed states, passes through weak or vulnerable states, and culminates with stable or consolidated states. In contexts characterized by a tenuous or weak state presence, formal institutions achieve some degree of effectiveness thanks to the mediation of non-state institutions that follow their own logic or that are informal (Boege et al., 2008, pp. 3-7).

As Boege et al. (2008) assert, the identification of a state as weak implies recognizing the existence of other political actors that are strong in relation to the state. This is especially true in societies where the idea of the state has not solidified in a solid manner and where the notion of citizenship, as opposed to other, more rooted identities, does not connect with individuals (Turnbull, 2002). In these contexts, social actors can combine formal and informal institutional practices, developing hybrid institutions. Moreover, one can think of an institutional continuum in which the actors choose a course of action 
by combining normative practices with traditional, moral, or customary ones (Sindzingre, 2006). The legitimacy of these hybrid institutions is based on reference to socially acceptable ways of doing things, as well as existing or previous tradition, identity, rights, or relationships of authority (Hall et al., 2014).

Assessments of state-building policies based only on the understanding of such societies as fragile states have, however, shown a series of problems in the achievement of their objectives (Grävingholt et al., 2012), so that some alternative perspectives that understands these spaces as hybrid political orders have been developed (Boege et al., 2008, 2009). From this alternative perspective, there are informal institutions that dispute to the state their privileged position in the establishment of rules and procedures of coexistence. These institutions, such as those generated by religious movements or transnational criminal networks, have the capacity to establish norms of coexistence and some type of order (Mehler, 2003).

The central issue, however, is not necessarily to find mechanisms to incorporate informal institutions into the hierarchies of the state. The instrumental use of native or local institutions by for example colonial governments through the indirect rule is already known (Asad, 1973; Hart, 2006) and does not constitute a real collaboration: the state recognizes traditional chiefs to build their power, and, in return, the bosses take refuge in a powerful and foreign structure, which may call into question its legitimacy vis-à-vis the population (Boege et al., 2008, p. 8).

Moreover, the collaboration of formal and informal institutions does not consist necessarily in an inclusion of a weak structure by a stronger one. Actually, the places where the limits between formality, informality, or even legality are diffuse constitute fertile spaces to produce institutional hybridization rather than collaboration (Das \& Poole, 2004). In such contexts, frictions occur between traditional collective identities and the notions of state citizenship, frictions that need to be transformed into constructive interactions to build an effective state. For this, it is useful to think about the fundamental functions of the state and how they are being carried out in these spaces, as well as to address the sources of legitimacy of formal and informal institutions. The functions of the state, as recognized by Clements et al. (2007), are not an end by themselves, and in conditions of hybridity, their ultimate objectives of providing development, security, and peace can be best achieved through institutional hybridization and not by processes of state formalization.

This article aims to shed light to the institutionalization of practices that regulate the actual social interaction in extractive realms. It argues that these rules are formed in a dynamic with formal and informal institutional frameworks. Thus, they can be related to state norms, corporate, and/or local practices, forming hybrid institutional entanglements which cannot be fully enclosed by a single formal or informal institutional framework. The way such institutions are produced and reproduced depends on the state and other social actors' agency and political leverage.

In developing this argument, the article asserts that hybrid institutional entanglements are dynamic, and as such it is fundamental to understand hybrid entanglements in a continuum from almost-informal to almost-formal 
institutionalized practices. Moreover, the state may formalize practices or legally ban them in the context of changes to public policies. These changes may not significantly affect the reproduction of rules in places where the state is not capable or has no real interest in implementing formal law, but certainly could move such institutions to the formal or informal side of the continuum.

In addition, following Boege (2017, p. 219), this article asserts that hybridization of formal and informal institutions reveals the variety of forms of political and economic agency of the subjects in specific social situations: obstruction, resistance, capture, re-appropriation, cooptation, or subordination. As Chatterjee (2004) asserts, societies are divided by an axis of legality in which there is an illegal component that, however, is backed by a certain social legitimacy. In such situations, hybridity can emerge as a political tool that directs the action of the state, redirecting its resources towards the interests of the group. So, the question that emerges at what point the hybridizations become "dysfunctional" and to what extent it can be said that it orders "consolidate the position of the local and traditional elites", reinforcing in this way social inequalities of different types (Bagayoko et al., 2016, p. 15).

This conceptual framework allows us to analyze the way by which power in the two different cases proposed in this article influence the characteristics acquired by formal-informal institutional entanglement, in spaces of greater or less institutional hybridity.

\section{Institutionalized practices as hybrid institutional entanglements}

The two cases presented show how social actors combine formal and informal frameworks in institutionalizing their practices; however, they do so from different power positions vis-à-vis the state. While agribusiness companies are able to use political influence, small-scale miners can resist state regulations. In both cases, power shapes the way institutional hybridization has unfolded.

\section{Case 1: Agribusiness companies' extraction of scarce groundwater resources in Ica: institutional hybridization pushed from above}

Since the early 1990s, the Peruvian government's policy was mainly to appeal to private investments for agro-export expansion. This policy attracted domestic and foreign capital, introducing for new export crops. With increased demand for asparagus on the international market, the Ica Valley consolidated by the end of that decade as one of the country's main agro-export zones.

Under this productive model, small family farms were regarded as inefficient in producing for a global market requiring high-quality, massive volume, and constant production. Therefore, the government concentrated on appealing to and fostering the formation of export companies with access to large land areas. Between 1994 and 2012, while agricultural land ownership between 100 and 500 hectares increased by $19.67 \%$ in Ica, large-sized 
properties of 500 hectares or more increased by 347.90\% (INEI, 1994, 2012). Mass-production of new crops mainly for export has risen along with traditional cotton. The model's economic success is intimately linked to the increased worldwide demand for fresh crop luxury foods, which is accompanied by a steeply increased demand for resources (water and land) to grow these products. The main crops produced by the agribusiness were asparagus (whose harvest area has increased from 411 ha in 1991 to 10,400 ha in 2011) and table grapes (with a harvest area increase from 3,000 ha in 1994 to 5,082 ha in 2011) (ANA, 2018). Export destinations for the table grapes have changed from Europe and the United States to China because of less stringent agrochemical residue norms.

In addition to population growth, this agro-export boom brought increasing demand for groundwater. The Ica River irrigates the Ica Valley, while aquifers are located in the west end of the valley close to the sea (see Figure 5.1). Currently, the Ica River and aquifers feed some 26,000 ha of irrigated land in the Ica Valley, while also providing water to the city of Ica and surrounding villages.

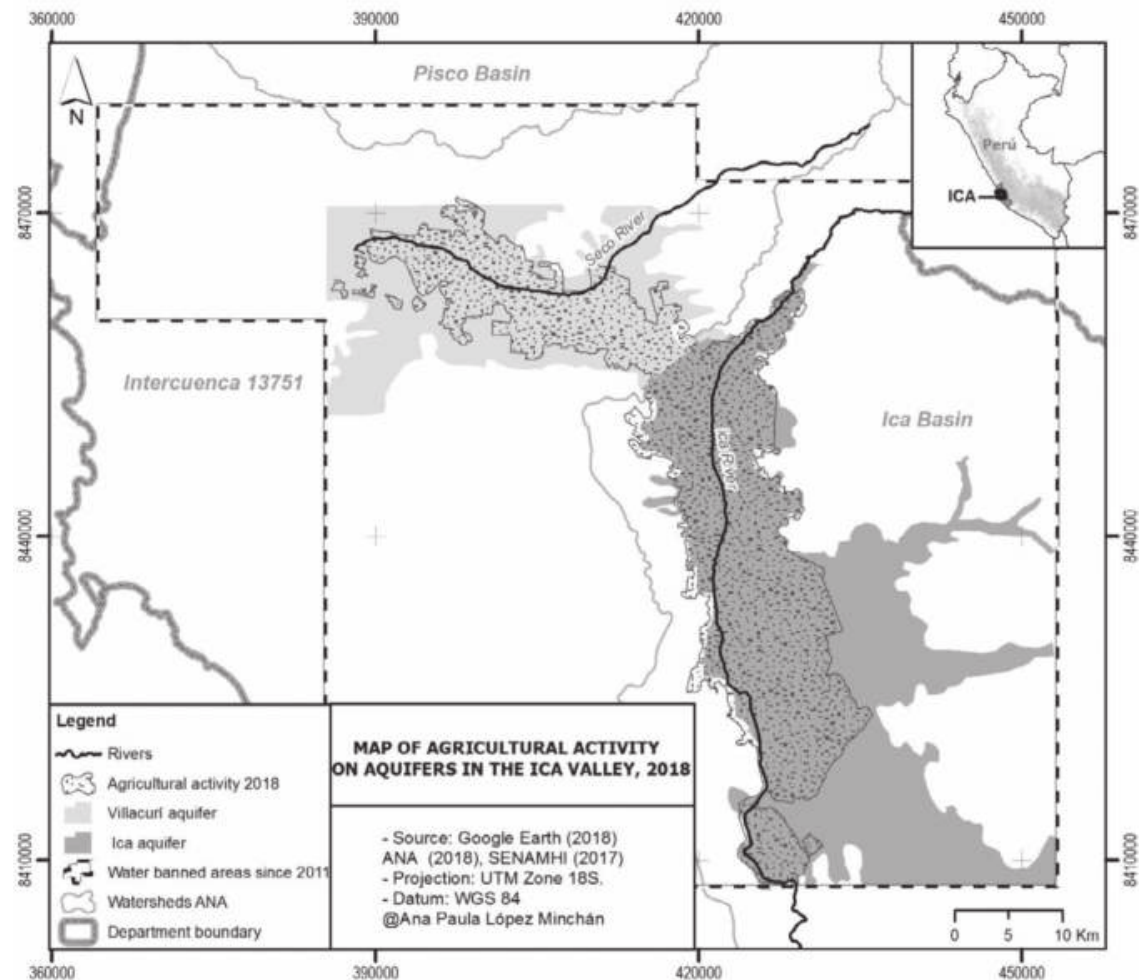

Figure 5.1 Map of agricultural activity on aquifers in the Ica Valley, 2018 (UTM-18S)

Source: Own elaboration 
Most small- and medium-size holders irrigate their land from the river, while large-scale producers use groundwater from the Ica and Villacurí aquifers.

The agro-export boom in the Ica Valley has had profound consequences in terms of generating water scarcity (Damonte et al., 2014; Damonte, 2015; Damonte \& Boelens, 2019). In an arid climate such as Ica's, expanding the agricultural frontier requires access to new water sources. In this scenario, agroexporters are the ones with the necessary capital to access groundwater, which is the only additional quality water source available at this time. In accordance with the reports of the National Water Authority (ANA), in 2009 the exploitation of the aquifers surpassed the reserve volume by $125 \%$ and in 2013-2014 by 171\% (Muñoz \& Zuñiga, 2018, p. 114).

What are the formal rules and procedures for groundwater extraction in the Ica Valley? Before 2019, there was no formal regulation for groundwater extraction. In 2009, a new law for water resources was enacted in Peru. In their regulatory norms enacted in 2010, this law establishes that the well owner must be a formal producer and needs to own the land where the well will be built and get a usage license that is a water concession for each well in use. The amount of water the producer can extract in a given period is specified in the water concession. The producers must assume all costs related to the well building and maintenance. Agribusiness companies own and use the vast majority of groundwater wells over the aquifers of Ica, Lanchas, and Villacurí. These companies are formal producers and formally own the land where wells are located; however, just a small number of the wells have usage licenses, and the others have been informally built or are informally used. Official numbers show that in Ica, some 860 groundwater wells are installed, of which only 249 have a license (ANA, 2018).

In addition, the state previously had a formal right to directly control the amount of water extracted in each well. However, the agribusiness association fiercely opposed direct state regulation during the discussion about the regulation of the new law of 2019. Indeed, they even physically prevented ANA functionaries from entering their private property where their wells were drilled, despite the legal mandate for state regulation. So, the state resorted to include them as well. In such a situation, all well licenses could have been canceled and thereby all actual wells used would be considered to be informal or illegal, but the state did not want to start such a fight with the agribusiness companies, so the legal regulations in place since 2010 assign to the wells' owners an obligation to count and declare to the ANA the amount of water they extract, in effect giving agroexport companies the right to self-regulate. From then on, companies have simply declared to the water authority the amount of water they extract.

However, the formalization of a former informal self-regulation of the volume of groundwater extraction per well did not resolve the issue of the increasing number of informal wells in the context of increasing groundwater scarcity. Thus, the state decided to declare a water emergency in the Ica region. In 2011 Chief Resolution No. 330 was passed, thereby ratifying a ban on the drilling of new boreholes in Ica and the prohibition of new underground water use rights 
in Villacurí and Lanchas. ANA's local officials have focused on detecting illegal drilling works, identifying non-registered wells, and inspecting flow meters in order to verify the quantity of water being extracted. As a result, infringers have been issued fines up to S/.3,850 (approximately USD1,200), and unlawful wells, mostly on the land of small holders, have been closed. Just before this punitive process, the government declared a legal amnesty for all informal wells that were informally used. Companies could formalize their informal wells with no fines just before the ban on new wells took place.

The policy was partially successful since many existing informal wells were formalized or closed down, but it did not prevent the drilling of new informal wells by the companies. So, the government enacted a new norm that allowed the producers to build new wells but only to replace unusable old ones. Again, this norm facilitated the formalization of formerly informal wells, but did not prevent the companies from continuing to drill wells to supply their increasing groundwater demand for cropping crops for exports. ANA estimates that the number of informal wells has increased even during the water ban period: by 2015 , about $65 \%$ of wells in Villacurí and $81 \%$ in Lanchas had no license at all (ANA, 2015). Clearly, the self-regulation policy was not working, but the lack of adequate government regulation seems to be politically motivated and key to the constitution of their territory, especially since small and medium well owners have been regulated. Agro-exporters, on the contrary, rely on their power and political legitimacy to avoid state oversight.

Throughout this period, the companies have extracted the water they have needed for furnishing their increasing demand with no effective state regulation even in the context of water scarcity and emergency. This practice has been institutionalized since no effective state sanction or significant social opposition has been able to prevent it. The state has tried to firm up their formal framework while other possibly affected water users have not raised their voices against companies' extractive practices (Damonte, 2015). The actual rules and procedures that govern the companies' extraction of groundwater entangles formal rights and informal procedures: companies are formal, part of their wells is formal, their exports follow formal channels and pay formal taxes; however, they informally manage the number of wells and the amount of water extraction in accordance with their markets' needs, irrespective of formal rules or environmental concerns.

In Ica as in other Peruvian coastal valleys, the agro-export group's political and economic power has become the main agent driving hydro-territorial redefinition (Damonte, 2019; Damonte \& Boelens, 2019). Supported by the neoliberal polices and mindset promoted by the government in the last decades, the agro-export companies established their power by developing the financial and technical capacity to pursue high-tech export agriculture and contest existing territorialities and alternative imaginaries related to smallholders' livelihood, food-based agriculture, and dignified drinking water services for the cities. Next, they build on their political capacity to establish the rules to access groundwater, overriding other organizations in the watershed-including the state- and legitimize their water control using the dominant discourse (Damonte 
\& Gonzales, 2018; Damonte et al., 2016). Private enterprise makes the desert bloom; it earns foreign exchange for the country and provides employment for the region; it uses cutting-edge irrigation technology so they are an example of "efficient" water management, which must be followed to utilize other abandoned land in Ica and other valleys on the Coast.

\section{Case 2: Institutionalized practices for small-scale miners' access to gold alluvial deposits in the Amazonia: an institutional hybridization pushed from below}

Madre de Dios is a region in the southern Peruvian Amazon bordering Bolivia and Brazil. With a total population of approximately 134,100 permanent residents, it is the least-populated province in the country (INEI, 2014). Over the last decade, this province has caught national attention due to the massive environmental destruction caused by the multiplication of small-scale mining activities in this fragile environment (Damonte et al., 2013; Ipenza \& Valencia, 2014; Mosquera, 2006; Pachas, 2011a; Valencia, 2014; Dargent \& Urteaga, 2016; Baraybar \& Dargent, 2020) (see Figure 5.2).

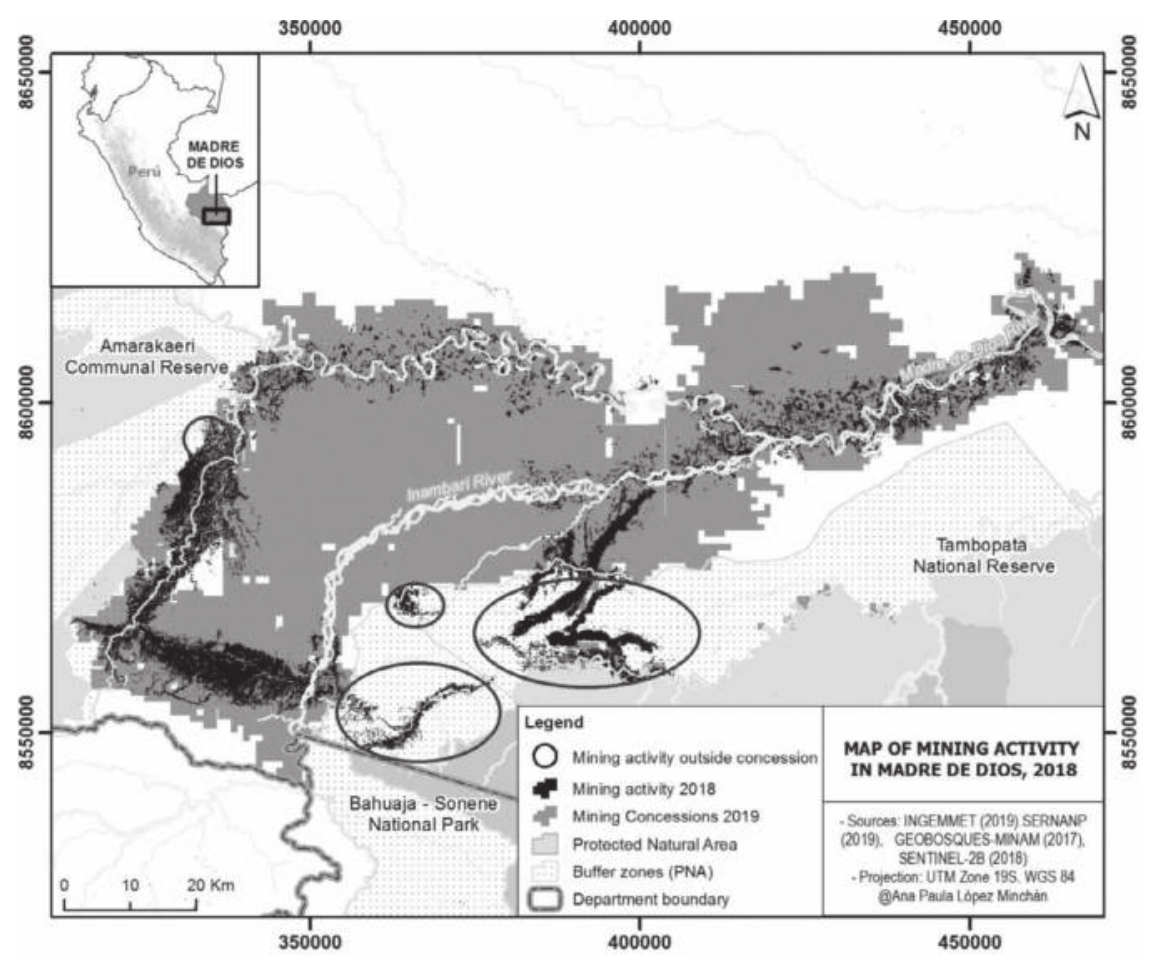

Figure 5.2 Map of mining activity in Madre de Dios, 2018 (UTM-19S)

Source: Own elaboration 
The miners are the most important group in economic and political terms, although they represent only around $10 \%$ of the population (Mosquera et al., 2009; Pachas, 2011b). Most miners are Andean immigrants, but there are also some Amazon natives and even a few foreign miners from China and Russia.

In Madre de Dios, miners have differing ways to access ore deposits. There are miners with formal mining concessions given by the state. They are the formal concession holders and have the right to formally mine in their concession. Sometimes, formal holders prefer to invite guest miners to mine on their concessions for a payment, usually a percentage of the ore extracted. In this case, the guests are informal miners, informally allowed by formalized miners to access their formally received concession. However, miners can also invade a vacant concession or no-mining zone and seek social (informal) recognition as holders by force or by claiming first possession rights. Again, they can invite guest miners. Then, there are the peons who are miners working for holders or guests for a payment, usually a small percentage of the gold extracted daily, called a royalty. Finally, the chichiqueros are miners who temporarily invade other people's concessions where they mine individually until the holder finds out. They are independent, free, and mobile miners.

Thus, in Madre de Dios miners have four non-exclusive ways to access the ore deposits: as a holder, as a guest, as a peon, or as a chichiquero, which made up several combinations. Just as an example, a miner can hold formal and informal concessions and be a guest miner in another holder concession. Moreover, a chichiquero can be also a peon. In general, newcomers are peons and chichiqueros who aspire to someday become guests and then holders, which had commonly happened in the context of actual labor mobility and extractive territorial expansion.

The rules and procedures for accessing ore deposits are clear and well established; they are mostly informal institutions. Just when formal holders access their given concession directly or through formally hired workers, it is following only formal norms for accessing ore deposits (and formal concessions account for only a small portion of the mining land). Moreover, almost no formal holders comply with all formal requirements for mining extraction, such as environmental provisions, so there is almost no completely formal mining in the region. However, the most common ways to access the ore deposits are completely informal, and their degree of informality is changing in accordance with changing state formalization initiatives and policies.

Before 2001, there were no specific formal rules to govern small-scale mining in Peru. In that year, the government enacted a Supreme Decree (27651), ${ }^{1}$ officially recognizing artisanal mining for the first time and incorporating it into the General Mining Act. The law defines artisanal miners as individuals or groups who work for their living by mining manually or using rudimentary equipment. In the case of gold producers in gold placer ore deposits formed by gravity separation during sedimentary processes, which is the Madre de Dios case, production capacity must be at most $200 \mathrm{~m}^{3}$ / day for being considered artisanal mining (Mosquera et al., 2009). Under this formal framework, miners are required to 
obtain a tax number and a mining concession or a mining contract with the concession owner, as well as an artisanal miner certificate in order to access the ore deposits. From this general framework, the state started to develop regulations to foster formal and prevent the expansion of informal artisanal mining.

In 2005 the government passed the Environment Act (2005), which defines the guidelines for environmental management, the sustainable use of natural resources, and land planning and zoning in Peru. The EEZ proposal establishes eight zones grouped into five main categories (Fernandez, 2010). It prioritizes ecological protection (49.64\%) and non-mining production (40.22\%), leaving just $10.14 \%$ of the territory for potential small-scale mining activities. Interestingly, this zoning plan does not preclude large-scale extractive projects since it addresses only land use, not subsoil resource extraction - though it could establish some land access restrictions for extractive purposes particularly in conservation areas.

However, new miners' groups in the 2010s expanded their activities into banned reserves areas' buffer zones such as La Pampa, which overlaps with the buffer zone of Tambopata National Reserve, transgressing the mining limits established by the EEZ and menacing this protected area. In February 2011, the state responded by enacting Act 1100 which declared illegal all mining activities not authorized by the state. As a result, informal miners mining ore deposits in rivers, lakes, and protected areas become illegal miners. Subsequently, the Ministry of Environment urged the navy to launch a punitive campaign against illegal miners in the region, sinking many dredger boats on the Madre de Dios River. In the same 2011, the Ministry of Energy and Mines published the Supreme Decree No. 013-2011, approving the National Plan for the Formalization of Artisanal Mining (PNFMA).

Miners resisted the state pressure for formalization and mobilized against punitive campaigns. They accused the state of being ill prepared to understand the mining activities in the region while demonstrating against state crimes towards miners in the context of punitive campaigns. After some years, it was clear that the formalization plan was a failure in the region since less than $1 \%$ of miners were trying to obtain the status. Consequently, the state looked for some policy changes to provide incentives for miners to seek formalization (Damonte, 2016, 2018).

In 2013, the central state enacted a supreme decree to create an exceptional procedure under the same law to drive forwards formalization. ${ }^{2}$ Under this exceptional procedure, non-formal miners are required to submit a declaration of commitment in order to be considered "in the process of formalization", until they fulfill all the requirements to complete the process. This opened up a new window for informal miners to achieve certain degree of formalization. Moreover, the ministry of environment recognized some chichiquero associations as miners "in the process of formalization" (Damonte, 2018). Interestingly enough, chichiquero miners have neither formal nor informal concessions, and many of them work in no-mining zones such as La Pampa, so the window of formality was opened also for illegal miners.

The same process of repression and conciliation has been repeated several times since 2010. The government, with the support of the media and public 
opinion, launches a repressive intervention against so-called illegal miners, but the miners resist, and the pace of formalization stops. Miners mobilize against punitive measures through demonstrations, road blocks, and general strikes. The government is forced to put the formalization process on hold and establish roundtables to conduct dialogue and negotiate some conditions. By 2014, more than $90 \%$ of miners were "in process of formalization" in Madre de Dios, but by 2020, when the formalization process has been suspended due to the Covid-19 pandemic (Benites \& Bebbington, 2020), very few had completed the process. Rules and procedures for access to ore deposits have not changed.

In this case, small-scale miners' power to produce and reproduce their rules for ore deposits comes from their capacity to mobilize and negotiate state regulations (Cortés-McPherson, 2019). State policy has tried to regulate the access to ore deposits by creating mechanisms for recognizing actual miners (as artisanal miners) as well as limiting their area of extraction (no-go zones) (Pachas, 2011a; Pachas, 2011b). Miners have responded to these evolving formal frameworks by accepting recognition and resisting punitive campaigns (Damonte, 2021). They have chosen to accept some state regulations to get some rights and recognition that in turn would help them to resist other regulation. In this way, the institutionalized practices to access ore deposits in Madre de Dios are mostly but not completely informal; that is, they can be regarded as hybrid institutional entanglements.

\section{Final remarks}

The institutionalization of informal institutions has been a fundamental process for developing governance schemes in the context of extractive expansion. Extractive activities have flourished without formally established or actually enforced rules and procedures. In such contexts, some local practices have been reproduced and produced as informal institutions to govern extractive intensification and territorial expansion and as a way to maximize the unregulated use of resources. In addition, the reproduction of informal institutions in the context of increasing state regulatory efforts has fostered processes of institutional hybridization.

The cases of water extraction in Ica and alluvial gold deposit access in Madre de Dios show how agro-export companies and miners institutionalized their extractive practices not just as informal institutions but as hybrid institutional entanglements. In Peru, the state has gradually developed formal frameworks to regulate extractive activities, but these formal regulations have been only partially adopted (Damonte, 2021). Agro-export companies and miners have chosen to follow some formal procedures while maintaining their informal rules, intertwining formal and informal frameworks to get formal rights to extract resources while avoiding the regulation that would restrict their extractive activities. Thus, the rules and procedures for water extraction and ore access are not formal but not completely informal either.

Moreover, the way these hybrid institutional entanglements have been constituted has depended on the power balance between the different state 
regulatory agencies and the companies or local groups that pursue unregulated extractive activities. In the first case, agro-export companies are able to compel the state to formalize some of their informal extractive practices while avoiding the effective regulation of others such as the volume of water extracted. In this sense, they have hybridized the state governance from above, showing their power to influence state regulatory efforts (Damonte, 2019). In the second case, miners have effectively resisted state regulation in order to get recognition and negotiate changes in the state institutional frameworks. Thus, they have hybridized state governance from below. In both cases, hybrid institutional entanglement has been the result of power-laden disputes for resources control between the state (in its different levels, sectors, and branches) and local extractive agents. These cases show that different social groups establish diverse relationships with the state based on their political interests and capacities (Chatterjee, 2004). Thus, more than the weakness or institutional strength of the states, the nature of the formation of the entanglement between formal and informal institutions will depend on the way in which the political scenarios that frame the institutional development in different social spaces have been constituted.

The hybridization of governance schemes in places of extractive expansion or intensification have generated significant institutional challenges for governance, which may be understood in the theoretical realm of institutional curses. Governments eager for windfall profits have opened up territories for extractive developments without proper public regulation, creating conflictive and sometimes ungovernable scenarios. However, this is not to say that a lack of established state regulation has produced only chaos; extractive agents have managed to establish governance schemes by institutionalizing their practices as institutional entanglements. Thus, the possible institutional curse would depend on the forms adopted by these entanglements and their functionality in the quest for developing more institutional governance.

Analyses of these cases prove to be no exception, and reinforce the argument already present in the literature that informal institutions and hybrid institutional forms do not respond to situations of marginality, but structure in themselves forms of social behavior (Boege, 2017; Sindzingre, 2006; Helmke \& Levitsky, 2004; Olivier de Sardan, 2013). Thus, state presence does not lead to some linear process of gradual formalization but to processes of hybridization or distinct assemblages (Li, 2005) that are established dynamically between local groups and different state representatives. In such scenarios, power disputes play the key role in shaping institutional governance precluding or reinforcing institutional rule.

\section{Notes}

1 Supreme Decree No. 013-2002, passed April 21, 2002.

2 Supreme Decree DS 032-2013-EM enacted on August 23, 2013. 


\section{References}

Asad, T. (1973). Anthropology and the colonial encounter. Ithaca Press.

Autoridad Nacional del Agua-ANA. (2015). Plan de gestión del acuífero de Ica-VillacuríLanchas. Estado situacional de las aguas subterráneas. https://repositorio.ana.gob.pe/bitstream/ handle $/ 20.500 .12543 / 2284 /$ ANA0000987. pdf? sequence $=1$ \&isAllowed $=\mathrm{y}$

Autoridad Nacional del Agua-ANA. (2018). Plan de gestión del acuifero del valle de Ica y pampas de Villacurí y Lanchas. www.ana.gob.pe/sites/default/files/normatividad/files/ ica_-_plan_de_gestion_0_0.pdf

Bagayoko, N., Hutchful, E., \& Luckham, R. (2016). Hybrid security governance in Africa: Rethinking the foundations of security, justice and legitimate public authority. Conflict, Security \& Development, 16(1), 1-32. https://doi.org/10.1080/14678802.2016.1136137

Baraybar, V., \& Dargent, E. (2020). State responses to the gold rush in the Andes (20042018): The politics of state action (and inaction). Studies in Comparative International Development, 55, 516-537. https://doi.org/10.1007/s12116-020-09314-5

Benites, G. V., \& Bebbington, A. (2020). Political settlements and the governance of COVID-19: Mining, risk, and territorial control in Peru. Journal of Latin American geography, 19(3), 215-223.

Boege, V. (2017). Looking beyond institutional reform: Engaging with the hybridization of peace and political order. Two cases from Oceania and West Africa. In N. Ansorg \& S. Kurtenbach (Eds.), Institutional reforms and peacebuilding change, path-dependency and societal divisions in post-war communities (pp. 218-236). Routledge. https://doi.org/10.4324/9781315545219

Boege, V., Brown, A., \& Clements, K. (2009). Hybrid political orders, not fragile states. Peace Review: A Journal of Social Jjustice, 21(1), 13-21.

Boege, V., Brown, A., Clements, K., \& Nolan, A. (2008). On hybrid political orders and emerging states: State formation in the context of 'fragility'. Berghof Research Center for Constructive Conflict Management.

Chatterjee, P. (2004). The politics of the governed. Reflections on popular politics in most of the world. Columbia University Press. www.jstor.org/stable/10.7312/chat13062

Cleaver, F. (2002). Reinventing institutions: Bricolage and the social embeddedness of natural resources management. European Journal of Development Research, 14(2), 11-30.

Clements, K., Boege, V., Brown, A., Foley, W., \& Nolan, A. (2007). State building reconsidered: The role of hybridity in the formation of political order. Political Science, 59(1), 45-56.

Cortés-McPherson, D. (2019). Expansion of small-scale gold mining in Madre de Dios: "Capital interests" and the emergence of a new elite of entrepreneurs in the Peruvian Amazon. The Extractive Industries and Society, 6(2), 381-389.

Damonte, G. (2015). Redefiniendo territorios hidrosociales: Control hídrico en el valle de Ica, Perú (1993-2013). Cuadernos de Desarrollo Rural, 12(76), 109-133. https://doi. org/10.11144/Javeriana.cdr12-76.rthc

Damonte, G. (2016). The "blind" state: Government quest for formalization and conflict with small-scale miners in the Peruvian Amazon. Antipode, 48, 956-976. https://doi. org/10.1111/anti.12230

Damonte, G. (2018). Mining formalization at the margins of the state: Small-scale miners and state governance in the Peruvian Amazon. Development and Change, 49(5), 1314-1336. https://doi.org/10.1111/dech.12414

Damonte, G. (2019). The constitution of hydrosocial power: Agribusiness and water scarcity in Ica, Peru. Ecology and Society, 24(2), 100-120. https://doi.org/10.5751/ES-10873-240221

Damonte, G. (2021) Limited state governance and institutional hybridization in alluvial ASM in Peru. Resources Policy, 72, 102118. ISSN 0301-4207. https://doi.org/10.1016/j. resourpol.2021.102118 
Damonte, G., \& Boelens, R. (2019). Hydrosocial territories, agro-export and water scarcity: Capitalist territorial transformations and water governance in Peru's coastal valleys. Water International, 44(2), 206-223. https://doi.org/10.1080/02508060.2018.1556869

Damonte, G., Bueno de Mesquita, M., Pachas, V. H., Chávez, M., Flores, A., \& Echave, J. (2013). Small-scale gold mining and social and environmental conflict in the Peruvian Amazon. In L. Cremers, J. Kolen, \& M. Theije (Eds.), Small-scale gold mining in the Amazon: The cases of Bolivia, Brazil, Colombia, Peru and Suriname (pp. 68-84). CEDLA. ISBN (Print) 9789070280185

Damonte, G., \& Gonzales, I. (2018). Política pública, relaciones de poder y conflicto de intereses en la gestión del agua en Ica. In M. T. Oré \& I. Muñoz (Eds.), Aguas en disputa. Ica y Huancavelica, entre el entrampamiento y el diálogo (pp. 75-112). Fondo Editorial PUCP.

Damonte, G., Gonzales, I., \& Lahud, J. (2016). La construcción del poder hídrico: Agroexportadores y escasez de agua subterránea en el valle de Ica y Villacuri. Anthropologica, 34(37), 87-114.

Damonte, G., Pacheco, E., \& Grados, C. (2014). Dinámicas de concentración y escasez de agua: El boom agroexportador y los pequeños propietarios en las zonas medias y altas del río Ica. In G. Damonte \& M. T. Oré (Eds.), ¿Escasez de agua? Retos para la gestión de la cuenca del río Ica (pp. 127-171). PUCP.

Dargent, E., \& Urteaga, M. (2016). Respuesta estatal por presiones externas: Los determinantes del fortalecimiento estatal frente al boom del oro en el Perú (2004-2015). Revista de ciencia politica (Santiago), 36(3), 655-677. https://doi.org/10.4067/S0718-090X2016000300003

Das, V., \& Poole, D. (2004). Anthropology in the margins of the State. School of American Research Press.

Ferguson, J. (2005). Seeing like an oil company: Space, security, and global capital in neoliberal Africa. American Anthropologist, 107(3), 377-382. https://doi.org/10.1525/ a.2005.107.3.377

Grävingholt, J., Leininger, J., \& von Haldenwang, C. (2012). Effective statebuilding?: A review of evaluations of international statebuilding support in fragile contexts. DANIDA. https://doi. org $/ 10.2139 /$ ssrn. 2297942

Hart, K. (2006). Bureaucratic form and the informal economy. In B. Guha-Khasnobis, R. Kanbur, \& E. Ostrom, (Eds.), Linking the formal and informal economy: Concepts and policies (pp. 21-33). Oxford University Press. https://doi.org/10.1093/0199204764.001.0001

Hall, K., Cleaver, F., Franks, T., \& Maganga, F. (2014). Capturing critical institutionalism: A synthesis of key themes and debates. European Journal of Development Research, 26, 71-86.

Helmke, G., \& Levitsky, S. (2004). Informal institutions and comparative politics: A research agenda. Perspectives on Politics, 2(4), 725-740. www.jstor.org/stable/3688540

Instituto Nacional de Estadística e Informática-INEI. (1994). III Censo nacional agropecuario 1994. Instituto Nacional de Estadística e Informática.

Instituto Nacional de Estadística e Informática-INEI. (2012). IV Censo nacional agropecuario 2012. Instituto Nacional de Estadística e Informática.

Instituto Nacional de Estadística e Informática-INEI. (2014). Estado de la población en Perú. Instituto Nacional de Estadística e Informática.

Ipenza, C., \& Valencia, L. (2014). Perú. In C. Heck \& J. Tranca (Eds.), La realidad de la minería ilegal en países amazónicos (pp. 175-218). SPDA.

Leftwich, A. (Ed.). (2006). What is politics?: The activity and its study. Polity Press. ISBN: 978-0-745-63055-7

Li, T. (2005). Beyond "the State" and failed schemes. American anthropologist, 107(3), 383-394.

Mehler, A. (2003). Legitime Gewaltoligopole: Eine Antwort auf strukturelle Instabilität in Westafrika? Institut für Afrika-Kunde (IAK). 
Mosquera, C. (2006). El desafío de la formalización en la minería artesanal y de pequeña escala: Análisis de las experiencias del Perú, el Ecuador, Colombia y Bolivia. CooperAcción, Acción Solidaria para el Desarrollo.

Mosquera, C., Chávez, M., Pachas, V., \& Moschella, P. (2009). Estudio diagnóstico de la actividad minera artesanal en Madre de Dios. Lima: Fundación Conservación Internacional. http://mddconsortium.org/wp-content/uploads/2014/11/CooperAccion-2009-Estudio-Diagn\%C3\%B3stico-de-la-Actividad-Minera-Artesanal-en-Made-de-Dios.pdf

Muñoz, I., \& Zuñiga, A. (2018). El problema de sobreexplotación de los acuíferos de Ica y Villacurí-Lanchas: Estudio de caso bajo en enfoque institucional del manejo de los recursos de uso común. In M. T. Oré \& I. Muñoz (Eds.), Aguas en disputa. Ica y Huancavelica, entre el entrampamiento y el diálogo (pp. 113-165). Fondo Editorial PUCP. http://repositorio.pucp. edu.pe/index/handle/123456789/173069

North, D. (1990). Institutions, institutional change and economic performance. Cambridge University Press.

Olivier de Sardan, J.-P. (2013). Embeddedness and informal norms: Institutionalisms and anthropology. Critique of Anthropology, 33(3), 280-299.

Pachas, V. (2011a). Historia de una incertidumbre: Hábitat, conflicto y poder en la minería artesanal de oro de Perú. Earth First SAC.

Pachas, V. (2011b). A propósito del plan nacional para la formalización de la minería artesanal en el Perú. CooperAcción, Acción Solidaria para el Desarrollo.

Risse, T. (2011). Governance in areas of limited statehood. In T. Risse (Ed.), Governance without a State?: Policies and politics in areas of limited statehood (pp. 1-35). Columbia University Press.

Sindzingre, A. (2006). The relevance of the concepts of formality and informality: A theoretical appraisal. In B. Guha-Khasnobis, R. Kanbur, \& E. Ostrom (Eds.), Linking the formal and informal economy: Concepts and policies (pp. 58-73). Oxford University Press. https:// doi.org/10.1093/0199204764.001.0001

Turnbull, J. (2002). Solomon Islands: Blending traditional power and modern structures in the State. Public Administration and Development, 22, 191-201.

Valencia, L. (2014). Madre de Dios: ¿Podemos evitar la tragedia? Políticas de ordenamiento de la minería aurífera. SPDA. 


\title{
6 Prior consultation to halt the resource curse?
}

\author{
Potentials and pitfalls of a participatory \\ innovation in Peru and its implications \\ for the Andean countries
}

Riccarda Flemmer

\section{Introduction}

The recent cycle of the commodity boom as well as the reliance of national economies on resource revenues has driven Latin American governments to expand the extractive frontier further into the Amazon and the Andes (Bebbington \& Bury, 2013; Svampa, 2015). Indigenous peoples inhabiting these areas are the main affected parties and projects have significantly increased contestation between them, states, and companies (Engels \& Dietz, 2017). These socio-environmental conflicts have also turned violent because states and companies did not respect indigenous ways of life or their physical wellbeing.

Participatory processes have been used as indicators of a Latin American exceptionalism to the political resource curse (Ahmadov, 2014), with consultation mechanisms being promoted by international organizations, policymakers and academia as a central democratic means to improve resource governance and transform conflicts (GIZ, 2015; Laplante \& Spears, 2008; United Nations, 2011; World Bank, 2016). Scaling-up in-depth insights into the implementation of prior consultation in Peru - the only country in Latin America with a national framework legislation - this chapter explores and compares reasons for the implementation of prior consultations as well as the potential and pitfalls of consultations to reform resource governance in the Andean countries.

Prior consultation and the principle of Free, Prior and Informed Consent (FPIC) have become the most important participatory mechanisms for indigenous peoples vis-à-vis extractive industries. In international law, indigenous prior consultation was first introduced in 1989 by International Labour Organisation Convention 169 (ILO C169). Later, consultation rights and FPIC were recognized in the 2007 United Nations Declaration on the Rights of Indigenous Peoples (UNDRIP) as well as in the regional American Declaration on the Rights of Indigenous Peoples (ADRIP) from 2016. Only recently, since the late 2000s and early 2010s, consultation has been further institutionalized in the Andean countries - with Colombia being the only exception, conducting the first consultation process in 1994 (Rodríguez, 2011, p. 65). Therefore, Special Rapporteur on 
the Rights of Indigenous Peoples Rodolfo Stavenhagen first diagnosed an implementation gap in 2006 (see Wright \& Tomaselli, 2019, p. 279).

Consultation regulations and implementation progress have provoked a surprising and almost complete reversal in the political positions of actors. From being a central claim of indigenous movements and an unwanted obligation for governments and companies, the initial resistance of state and corporate actors changed to approval and - at the same time - the claims of indigenous peoples have turned into contestation and opposition by these previous advocates. However, international organizations and development agencies still celebrate consultations as a guarantee for indigenous peoples' rights per se and as a central means to tackle the high number of socio-environmental conflicts in the Andean countries. This chapter argues that prior consultation is highly contested and the shift in advocacy is due to the limitations of the processes implemented. In principle, consultation legal frameworks should permit affected indigenous populations to have a meaningful voice in state decision-making. However, the scope of domestic consultation regimes (Szablowski, 2010) varies substantially in legal texts and in practice.

The main argument of this chapter is that the reversal in the direction of advocacy has resulted from prior consultation being a promising institutional innovation established in constitutions and laws but was subsequently downsized by formal regulations of governments and state administration as well as by informal practices following corporate interests in the industry of resource extraction. Conceptually, the chapter takes an agency-focused perspective on the institutionalization of prior consultation combining critical approaches to law, participation and the transformation of resource conflicts used in the fields of international relations, postcolonial studies and anthropology. The empirical material stems from an in-depth study of indigenous mobilization and contestation leading to and accompanying the implementation of prior consultation in Peru. The data comprises transcripts of interviews and participant observations, primary sources, and legal documents during the law-making process in 2011 as well as during the implementation of prior consultations, especially in the hydrocarbon sector between 2012 and 2016. The empirical material is embedded into an extensive review of secondary literature on prior consultation in international law and domestic contexts.

The first section of the chapter introduces prior consultation as discussed in international law and distinguishes it from other mechanisms of citizen participation. The second section gives an overview on the reasons for and the progress of introducing prior consultation focusing on the Andean countries. The third section critically analyses the complexities of implementing prior consultation in the case of Peru. Based on these in-depth insights, the fourth section discusses the potential and pitfalls of prior consultation for reforming resource governance in the Andean region. Finally, the concluding section reflects on the broader implications of prior consultation as an institutional innovation to break the resource curse and to contribute to sustainable development. 


\section{Prior consultation and FPIC as institutional innovations}

Prior consultation is often presented as the most important institutional innovation in Latin American resource governance. Legal scholars have also termed prior consultation as a globally prevalent "new approach to ethnic rights and multiculturalism, with its own language and rules" (Rodríguez-Garavito, 2011, p. 268). Prior consultation can be understood as a participatory institution. In line with Falleti and Riofrancos (2018, p. 87) participatory institutions can be defined "as formal, state-sanctioned institutions explicitly created to augment citizen involvement in decision making over public goods or social services."

From the perspective of formal institutions, consultation processes are based on the international indigenous right to prior consultation and the principle of FPIC. The main international legal instrument in this regard is the ILO C169 and the UNDRIP. The ILO was the first international body to draft international frameworks for indigenous peoples' rights. Responsible for formulating international labor standards, the ILO started its concern for indigenous peoples out of preoccupation for their conditions as exploited workers and forced labor (ILO, 2009, p. 153). In the revision process of an earlier standard, prior consultation was first defined by the ILO C169 and later interpreted as a "cornerstone" of the Convention (ILO, 2009). The ILO C169 is the only legally binding instrument for indigenous peoples' rights on an international scale. The principle of FPIC was established by the UNDRIP, which is an important instrument of soft law (for a detailed account, see e.g. Barelli, 2012). Additionally, the ILO supervisory system and the UN Special Rapporteurs on indigenous peoples' rights articulate recommendations. In the Latin American context, the ADRIP, jurisprudence of the Inter-American Court on Human Rights (IACtHR), constitutional courts, and national constitutional frameworks and laws have influenced the implementation process. Recommendations of the Expert Commission on ILO C169 as well as jurisprudence of the IACtHR have influenced the implementation process (Baluarte, 2004).

Without going into detailed legal analysis, prior consultation and FPIC need to be distinguished from public participation, from corporate social responsibility programs (CSR) and from each other. First, indigenous peoples' participation has a different legal and normative basis than public participation. While public participation aims at involving citizens in democratic state decisionmaking, setting emphasis on equal rights for everyone, prior consultation and FPIC are derived from indigenous peoples' right to self-determination and their special connection to their lands. Therefore, standards for prior consultation specifically include cultural adequacy. Second, prior consultation and FPIC primarily are historical debts of postcolonial states and not company obligations. Third, consultation and FPIC both define indigenous peoples' rights but are two different legal concepts. A fundamental difference between these two concepts is that prior consultation should give indigenous peoples the opportunity to participate in decision-making but does not necessarily attribute decision-making power to them. In contrast, FPIC requires governments 
(and companies) to reach the consent of indigenous peoples before a project starts. Vice versa, indigenous peoples can withhold their consent and say no to external interventions.

The emergence of FPIC can be traced as a central controversial issue in the elaboration of formal international, regional and national legal texts as well as in regional and national court decisions (for detailed accounts, see e.g. Doyle, 2015). However, the concepts of consultation and FPIC are not clear cut (see e.g. Rodríguez-Garavito, 2011). Therefore, depending on weaker and stronger interpretations, prior consultation may or may not include FPIC.

\section{Reasons for implementing prior consultation in the Andean countries}

Legal texts and rulings on prior consultation and FPIC are the result of indigenous protests and are the subject of on-going controversies (see e.g. Falleti \& Riofrancos, 2018; Tomaselli \& Wright, 2019). Globally, Latin America is the region most advanced in the institutionalization of indigenous peoples' prior consultation and FPIC. The ILO C169, which is the only international treaty open for ratification exclusively referring to indigenous peoples, is almost a regional convention. The majority of 15 of a total of 23 ratifying states of ILO C169 are located in Latin America.

Although countries signed the ILO C169 early in the 1990s, many governments were reluctant to implement consultation rights. Briefly reviewing variation between the Andean countries in terms of legal frameworks and regulations, the ILO $\mathrm{C} 169$ has played a role in several constitutions of the 1990s and 2000s but has not resulted in coherent legal frameworks or the systematic implementation of consultation processes. In terms of legal frameworks, Bolivia ratified ILO C169 June 1991, consultation was then incorporated into a new law of hydrocarbons in May 2005, but prior consultation was not implemented "because it was not regulated" (UrteagaCrovetto, 2018, pp. 10-11). Under the government of Evo Morales, prior consultation was regulated for the hydrocarbon sector, the UNDRIP became part of national law, and the new Bolivian Constitution of 2009 granted ILO C169 constitutional status (Urteaga-Crovetto, 2018, p. 11). However, irreconcilable claims between the government and indigenous organizations hindered the adoption of a conjoint national legal framework on consultations (Schilling-Vacaflor, 2014). In the hydrocarbon sector, consultations are implemented starting in 2007 and in the mining sector in 2015 (Zaremberg \& Torres Wong, 2018, pp. 50-56). In Colombia, ILO C169 was ratified in 1991 and has constitutional status, and prior consultation was incorporated into the 1991 Constitution. Since then, the Colombian Constitutional Court has developed an ample jurisprudence to further define consultation procedure and substance (Urteaga-Crovetto, 2018, pp. 12-14). Prior consultations have been conducted in the extractive industries since 1994 (Calle Alzate, 2019 , p. 92). Ecuador ratified ILO C169, and the right to prior consultation 
was incorporated into the 1998 Constitution (Urteaga-Crovetto, 2018, pp. 14-16). In 2012, Executive Decree 1247 was adopted to regulate prior consultation, and the Secretary of Hydrocarbons (SHE) has been implementing consultations since 2013 (Burgos, 2015, p. 54). In Chile, different legal texts were adopted without indigenous participation, and a first regulatory norm under the Bachelet government had to be replaced by the new regulation DTO-66 of March 2014, which is also vigorously opposed by indigenous peoples (Blanco, 2016, p. 14; Tomaselli, 2019).

Recent literature has identified four reasons for states to legally implement prior consultation in the Andean countries that can be traced historically in the waves and counter-waves of the recognition of indigenous peoples' rights. First, indigenous mobilizations of the 1990 s reached a formal recognition of indigenous peoples' rights. The multiculturalist turn in Latin America refers to the success of indigenous movements in Latin America in establishing domestic political parties and forming at least part of the state governments, especially in Ecuador and Bolivia (see e.g. Van Cott, 2005; Yashar, 2005).

Second, indigenous peoples' rights recognized in the multicultural reforms remained only on paper. This limited impact resulted in frustration, which is most prominently reflected on by Charles Hale's criticism of the limitations of Neoliberal Multiculturalism (Hale, 2004). In this context, indigenous peoples' rights, including participation and prior consultation, had been formally recognized but were not put into practice. Therefore, scholars have frequently criticized an implementation gap of rights (Helmke \& Levitsky, 2006; SchillingVacaflor \& Flemmer, 2015; Sieder, 2011).

Third, a new wave of resource extraction moving into indigenous peoples' territories has caused high numbers of conflicts, which sparked protests in many communities, often in alliances with national as well as international human rights, environmental and indigenous organizations, leading to political pressure on governments (and companies) to implement consultation rights (Brysk, 2000; Wright, 2014). These protests also led to rulings of the Inter-American Court on Human Rights, with the Saramaka people versus Suriname (2007) and the Sarayaku people versus Ecuador (IACtHR, 2012) cases in favor of the right to FPIC being the most emblematic ones (Doyle, 2015).

Fourth, consultation processes were implemented and further regulated. Comments of the ILO have an influence on the international level and "[d] emonstrating compliance was also significant, as Convention 169 became a marker of internationally approved good behavior. Reactions to the request were soon to follow" (Larsen, 2016, p. 12). Although the legal implementation of prior consultation and FPIC are no longer rejected by governments in Latin America, their scope is highly contested. Against this background, the contested interpretation of regulations has become the new field of struggles over recognition in domestic contexts (Larsen, 2016, p. 11; RodríguezGaravito, 2011). 


\section{Implementation of prior consultation in Peru: unwanted change}

The Peruvian consultation law is internationally celebrated as a forerunner because it provides a national framework for prior consultations, which has served as a leading example for its neighboring countries, such as Bolivia, Brazil, Chile and Colombia; they are elaborating similar legislation. However, Peru's pioneering role came as a surprise for observers. The country has long been discussed as an outlier case in the multiculturalist turn of the region because of the absence of indigenous political parties at the national level despite having one of the largest indigenous populations in South America (e.g. Merino, 2019).

Peru had ratified ILO C169 under the authoritarian government of President Alberto Fujimori in 1994, a time still marked by the internal armed conflict (1980s to 1990s) with leftist guerrillas. However, the ratification was mainly to show donors compliance with international standards (Orihuela, 2014). For over a decade, the implementation of ILO C169 was not advanced in a comprehensive way. In response, indigenous and peasant communities staged protests against various projects and started conducting their own consultation processes to avoid imposed mining projects with the Tambogrande consultation being the most famous case (Fulmer, 2014; Walter \& Urkidi, 2017). In June 2009, the violence of the Baguazo conflict opened a window of opportunity for indigenous organizations to push for the implementation of prior consultation despite the strong opposition of the government of Alan García (2006-2011; Hughes, 2010).

In 2011, the newly elected left-wing President Ollanta Humala adopted the Peruvian Consultation Law (Law of the Right to Prior Consultation of Indigenous and Tribal Peoples, recognized in the Convention 169 of the International Labor Organisation (ILO), Law No. 29785: Republic of Peru, 2011; in the following: LPC) as part of his election promises in 2011. Peruvian indigenous organizations were then involved by the Humala administration in the participatory elaboration of a national regulatory norm. Indigenous organization had hoped for the regulation to fill flaws in the restricted version of the initially negotiated consultation law but were disappointed by the government's reluctance. Nevertheless, the Regulating Decree (Regulating Decree of Law 29785, Law of the Right to Prior Consultation of Indigenous and Tribal Peoples, recognized in the Convention 169 of the International Labor Organization (ILO), No. 001-2012-MC; Republic of Peru, 2012) was adopted without the approval of the main indigenous organizations in 2012 (Flemmer, 2019; Schilling-Vacaflor \& Flemmer, 2015).

From a legal perspective, the Peruvian consultation law even stays behind the minimal standards defined in international law. Despite being celebrated internationally, the legal framework and the further institutionalization of prior consultation in Peru are criticized by indigenous and civil society organizations for four main shortcomings: First, the legislation defines whom to consult in a narrow way. The consultation legislation establishes that the state has the 
authority to decide on the status of being indigenous. Further, the legal framework defines that only people directly descended from precolonial populations are to be considered indigenous peoples - which is more limited than the ILO C169 definition - and stipulates that the representative organizations that participate in the consultations have to be from the geographic area of the planned measure. Accordingly, higher-level indigenous organizations with more experienced leaders remain outside of the processes. Second, the legislation leaves all decisions about how to consult to the state. In this regard, the Peruvian government ignored indigenous demands for an obligatory phase of joint planning. Instead, the framework puts the consulting state entity in charge to prepare a consultation schedule and then present it to the peoples to be consulted. Third, the Peruvian consultation legislation insists that all measures, including extractive projects, adopted without consultation before the national legal framework went into practice, remained in force. From a legal perspective, this is ambiguous because the Peruvian government had already ratified ILO C169 in 1994, and therefore was formally obliged to implement consultations since 1995. Fourth, the LCP does not establish a consent obligation and the regulatory decree stipulated that reaching a consensus is mandatory only when relocation of indigenous populations or the disposal of hazardous waste is planned. The final decision about projects remains with the consulting state entity. The legal framework stipulates that only agreements are binding, which means that in the case of disagreement-if communities oppose a measure-the state can still implement the projects, but the communities do not have a legal possibility to veto them.

Under the subsequent Humala administration (2011-2016), a total of 24 consultation processes on extractive projects involving communities from 23 different indigenous peoples were concluded, 11 of which concerned hydrocarbon concessions in the Amazon, and four of which dealt with mining projects in the Andes (Ministerio de Cultura, 2016). For oil, gas and mining projects, the consulting state entities are sub-divisions of the powerful Ministry of Energy and Mines (MEM). As in the other Andean states, Peru's economy depends highly on the extraction of natural resources. Legally, the state owns all subsoil resources. The national government via the MEM is the central entity that defines areas for mining and hydrocarbon (oil and gas) concessions, organizes international auctions and signs contracts with the highest-bidding company. These formal concessions are leased for 30 to 40 years and managed by foreign companies, whilst only sub-contractors-for infrastructure etc.- are Peruvian (Orihuela, 2012).

For the hydrocarbon and mining sectors, the MEM decided that consultations are to be implemented only once in the licensing process of the projects. For hydrocarbon projects, this is at a very early stage when only a broad area for a future license is defined but there are no details on the projects and activities planned (Flemmer \& Schilling-Vacaflor, 2016). For mining, the consultation takes place very late, right before the company begins to work, when the project has already been designed (Merino, 2018)—which means either projects are 
not defined yet and impacts remain unclear, or that the project is already fully designed and difficult to change.

In the hydrocarbon sector, from the 26 hydrocarbon processes initially announced (El Comercio, 2013), only 11 were concluded by the end of the Humala government in 2016. Nine of these processes were concluded "as planned", one was partly opposed (Block 191), and one is still the subject of a contentious renegotiation for a new consultation (Block 192/Ex-1AB). Additionally, other consultation processes began but were cancelled due to local opposition (Block 157) (see Flemmer, 2019).

In general, the concluded consultation processes in Peru can be characterized by three shortcomings: First, the ownership of indigenous peoples is very limited. States usually design the proceeding, control the access to consultation arenas, and establish general rules of the game. Therefore, prior consultation has turned from an indigenous peoples' claim into a state-controlled space and a stage for state monologues. Second, the substantial participation of indigenous peoples during consultation is limited. Third, the influence of indigenous peoples on the results of consultations and ultimately on the projects' implementation is limited (for a detailed account, see Flemmer \& Schilling-Vacaflor, 2016). This is in line with a more general critique of the public participatory mechanisms implemented by the Peruvian government in resource governance since the 1990s. Formally, the country's legal framework for participation and environmental licensing has been celebrated for being one of the most advanced in the region (Orihuela, 2014). However, in practice, these mechanisms have proven to be ineffective for protecting the environment or for giving local populations a meaningful say, because they are partial to company interests focusing on attracting large-scale projects, rather than on state control (Dargent et al., 2017).

In mining, the implementation process started only after repeated claims from the Peruvian Human Rights Ombudsman, the Ministry of the Environment, indigenous and other non-governmental organizations at the end of 2015 (Irigoyen, 2016). The minister and high-ranking officials of the MEM qualified prior consultation polemically as an investment obstacle (La Primera, 2013) and repeatedly articulated opposition against the implementation of consultations together with mining companies (Gálvez \& Sosa Villagarcia, 2013). Until the end of Humala's term in 2016, four consultations were conducted. These were criticized for being rushed, i.e. taking between 34 to 43 days (Defensoría del Pueblo del Perú, 2015; Irigoyen, 2016). Critique was also articulated by the Peruvian human rights ombudsman about the interference of companies in the consultation processes and that the agreements would only repeat already established obligations of the MEM to supervise the projects (Defensoría del Pueblo del Perú, 2016). Nevertheless, these mining consultations were not contested, which was mainly because companies were already working in the areas and had previously established working agreements with the communities (Ocampo \& Urrutia, 2016).

However, indigenous organizations and communities have opposed the topdown implementation of consultations. In the same vein as indigenous people, 


\section{Riccarda Flemmer}

communities have opposed extractive projects and criticized the flawed public participation processes before prior consultations were conducted (SchillingVacaflor et al., 2018). Two hydrocarbon-related cases of contested consultations are particularly interesting: First, in the long conflictive history of the oldest Amazonian oil-producing region in Peru, Block 192 in the Northern Amazon region of Loreto, the state-led consultation has served indigenous organizations and communities as a platform to gain attention for long-standing claims for environmental remediation, compensation payments and an increase of communities' influence in the project design by UN entities and opened negotiations with the Peruvian Congress as well as with the Executive (Lévano, 2017). Second, in the southern Peruvian Amazon region of Madre de Dios, communities rejected participation in consultations convened by the state. In reaction to the communities' opposition, the state reduced the area of the future concession in order to not overlap with indigenous territories. This means that communities were able to use the state's formal obligation to conduct prior consultations to avoid a new hydrocarbon project on their territories by rejecting any consultation at all (Flemmer, 2019).

\section{Implications for the Andean countries: potentials and pitfalls}

The absence of national legal frameworks has long been an excuse for governments to not implement prior consultations. Peru is still the only country in the region that has adopted a general national framework law. However, other Andean states have incorporated prior consultation into legal regulations, and the implementation of consultation processes has made progress. The potential of prior consultation as an institutional innovation is commonly advertised as providing spaces to facilitate participation, mediate negative impacts on affected populations and ensure benefits for communities affected by resource extraction. Further, consultation processes are supposed to transform conflicts before they can turn violent and provide platforms to discuss and reconcile different visions of development (McNeish et al., 2015).

In the dimension of formal institutionalization, prior consultation is ambiguously interpreted and highly contested. Although Peru has set an important sign with the consultation legislation of 2011 and 2012-compared to Bolivia, Colombia and Ecuador-the law stays behind in the formal recognition of indigenous peoples and their rights (Schilling-Vacaflor \& Flemmer, 2015). However, even in countries more progressive in recognizing indigenous peoples' rights, such as Ecuador (Constitution of 2008) and Bolivia (Constitution of 2009), hybrid regimes between prior consultation and FPIC were established (Szablowski, 2010). In practice, the resource-based economies impose narrow interpretations of prior consultation (Schilling-Vacaflor, 2017 on Bolivia; Burgos, 2015 and Vallejon, 2014 on Ecuador). Falleti and Riofrancos (2014) speak of poison pills, which are formal rules, e.g. in the form of regulatory presidential decrees in Ecuador, that undermine the scope of participation. This means 
that whilst constitutions and national laws may establish consultation as part of indigenous rights, those rights become downsized by further regulations in the extractive industries sector or are limited by other political decisions. Larsen (2016) finds in a comparative study on Chile, Bolivia, Ecuador and Peru a trend of domesticating and compartmentalizing indigenous peoples' rights and limiting them by national interests in resource extraction. Also in Colombia, the government and private industries intended and partially annulled progressive rulings of the Constitutional Court recognizing FPIC (Doyle, 2015, p. 200).

Regarding effective participation, the literature has found that consultation processes are merely procedural. In Peru, the limitations on consultations included even the fact that the ideas, interests and identities of the weaker party - indigenous communities - are often not respected, and may not even enter into the process at all (Flemmer \& Schilling-Vacaflor, 2016; SchillingVacaflor \& Flemmer, 2015). Similar observations can be made in other Andean countries. Bolivia, for example, implements prior consultation processes in the hydrocarbon sector based on sectoral norms since 2007 with a narrow process. The state generally acts as an accomplice to the companies, using participatory arenas to silence dissent (Fontana \& Grugel, 2016; Schilling-Vacaflor, 2017; Schilling-Vacaflor \& Eichler, 2017). In the same vein, Colombia ultimately has the amplest experience in conducting prior consultations. However, these processes are considered to be merely procedural and are said not to give communities a meaningful say (Rodríguez-Garavito et al., 2010). In Chile, the recognition of indigenous peoples' rights is still absent in the constitution, but the legal implementation of prior consultation has advanced (Tomaselli, 2019). However, the government seems to consider "consultation as a tick in the box” (Ibid., p. 129). Recent protests against President Sebastián Piñera and the results of a referendum in 2020 call for revising the current constitution and holding discussions on further recognition and realization of indigenous rights in practice (Montes, 2020). Lastly, Ecuador has recently begun to put consultations into practice in the hydrocarbon sector in 2013. Yet, scholars find that the Ecuadorian processes were solely classified as prior consultation and much closer to a procedure collecting complaints than to a participatory process (Burgos, 2015; Leifsen et al., 2017; Vallejo, 2014).

Finally, prior consultations and legal frameworks for indigenous peoples' rights have been criticized as providing merely symbolic solutions to material problems (Fontana \& Grugel, 2016; Goodale, 2016). Power relations underlying resource extraction are highly asymmetric. Like the Political Ecology literature emphasizes, the structures distributing negative impacts and benefits of these projects are fundamentally asymmetric and unjust (Bebbington \& Bury, 2013). Consequently, prior consultations are implemented in this context of power asymmetry. While international standards, such as the ILO C169 and the UNDRIP, urge governments to share benefits with the affected communities, most negotiations only include compensation payments and social programs (Flemmer \& Schilling-Vacaflor, 2016; Schilling-Vacaflor, 2014, 2017). Also, the ECLAC report $(2014$, p. 23$)$ on indigenous peoples' rights in Latin America 


\section{Riccarda Flemmer}

concludes that the region has incorporated important participatory rights, but "too often there is greater emphasis on the consultation procedure than on reaching agreements for the full exercise of indigenous peoples' rights." As Torres Wong (2018, p. 144) writes,

in a context of persistent and deep economic inequality and generalized violence, it should come as no surprise that the implementation of the right to prior consultation has failed to protect Indigenous territories in the ways envisioned by its most forthright advocates.

Additionally, power asymmetries also exist within and between communities. In this regard, consultations have been characterized as favoring local elites, disadvantaging women (Eichler, 2019), and leading to fragmentation and conflict (Arellano-Yanguas, 2011).

Reasons for the limitations of prior consultation to reform resource governance are generally attributed to the poor institutional embeddedness and governments' lack of political will to meaningfully implement participatory reforms. In terms of institutional embedding, the preconditions for participatory governance are not in place in most countries. These preconditions include: On the state's side, the imposition of consultation procedures, a lack of intercultural capacities of the state personnel and the absence of follow-up mechanisms. On the communities' side, these include weak structures of local organizations as well as a lack of capacity to understand and evaluate the information presented by the consulting entity. In this regard, Schilling-Vacaflor and Flemmer (2015, p. 811) summarize: "Establishing these preconditions would result in state institutions capable of justly balancing the diverse interests at stake; measures that reduce power asymmetries within consultations; and joint decision-making processes with binding agreements." However, consultations with indigenous communities in remote areas suffer from an overload of demands for basic state services, when they are almost the sole contact between communities and the state (Ibid.). Another crucial issue is that the regulations were elaborated unilaterally by the state administration and the social movement actors were not included-or as in Peru, left the processes. Based on a comparison of the institutionalization of consultation processes in Bolivia and Ecuador, Falleti and Riofrancos (2018, p. 88) argue that

for the newly created institution to strengthen there must be a process of political incorporation of the mobilized social actors during the early stages of regulation and implementation. We show that while social mobilization is a necessary condition of institutional strength, it is not sufficient.

They conceptualize (Ibid., p. 91) institutional strength as institutions being "legitimate, efficacious, and enforced" and conclude (Ibid., p. 91), "[e]nforcement is not solely a function of the state's institutional capacities, but also of its willingness to apply the law and enact the institution." 
However, communities and their allies also have strategies to use prior consultation in informal ways. While for communities there is no formal legal way to veto projects through prior consultation processes, communities can still use formal consultations to (1) mobilize for more meaningful negotiations over project terms and agreements; (2) block processes and articulate broader grievances; (3) deny consultations and block projects (Schilling-Vacaflor \& Flemmer, 2020; also Jaskoski, 2020). Further, indigenous peoples started to refrain from engaging in dialogue with the state out of frustration that these processes do not respect their own development visions and because projects were implemented without their concerns being taken seriously (Leifsen et al., 2017). Indigenous organizations and communities have also claimed prior consultation and FPIC to be part of their own institutions and conduct self-led community consultation to decide about projects (Fulmer, 2014; Walter \& Urkidi, 2017).

\section{Conclusion}

This chapter explored why in the case of prior consultation the initial resistance of state and corporate actors has shifted to approval and-at the same time-the previous advocacy of indigenous peoples turned into contestation and opposition. The main argument is that this shifts in advocacy has resulted from prior consultation being a promising institutional innovation established in constitutions and laws but then has become downsized by formal regulations of governments and state administration as well as by informal practices following corporate interests of the extractive industries.

At the same time, despite the efforts of states and companies to limit it, prior consultation has nevertheless become more institutionalized throughout Latin America. After being formally established in the 1990s and 2000s, in the 2010s a wave of consultation regulations and participatory processes were implemented in the Andean countries. Reasons for the final push for institutionalizing prior consultation vary among the different countries. However, in almost all cases indigenous peoples' mobilizations and international pressure played a key role. For the Andean states, this means that institutional change was imposed by civil society actors, international organizations and donor agencies.

Rather than adapting the extractive sector to indigenous peoples' rights, prior consultation has been adapted to the logic of the extractive industries. For the Andean countries, scholars distinguish broadly between "classical", neoliberal forms of extractivism and more recent heterodox models of extractivism (Larsen, 2016) in Bolivia and Ecuador. Prior consultation has been institutionalized in both contexts but with similar results. In general, the processes implemented in the hydrocarbon and mining sectors have been criticized due to the state-controlled access to consultation, the limited influence of indigenous peoples during the processes and the narrow agreements. Thereby, particularly alarming is that the regulation of prior consultation has "contributed to disempower indigenous peoples and communities" (UrteagaCrovetto, 2018, p. 8). 
Beyond shortcomings in the implementation of consultation processes, a fundamental problem is that prior consultation and FPIC are implemented as isolated mechanisms without changing the general logic of the extractive industries sector. Two factors are responsible for this: On the one hand, this is an issue of strategic framing that narrows discussions over indigenous peoples' rights to procedural questions and single participatory instrument (RodríguezGaravito, 2011; Merino, 2018). On the other hand, prior consultation and FPIC on a more profound level have problematic conceptual underpinnings. First, consultations are conducted only once during the life-cycle of a project. Timing is important, and consultation starts rather too early before projects are designed, or too late when changes are no longer possible. Either way, projects and conditions may change, and therefore participation needs to be continuous. Second, the role of indigenous peoples becomes merely reactive as they are confronted with outsiders' proposals to either reject or approve, but lack any further say in the actual construction and negotiation of the proposals themselves (Masaki, 2009).

In conclusion, the potential of prior consultation to reform resource governance is at present rather limited. Prior consultations in the Andean countries range on a spectrum between two points: The minimal state-led interpretation converts prior consultations into stages for project advertisement and state monologues. Thereby, consultation turns into an instrument that serves to legitimize extractive projects which have been already approved. In their more meaningful version, consultations can at least serve to (re)configure project designs to lower their impact on local populations and ecosystems and to (re)negotiate compensation payments and/or the funding of social projects. However, in comparison to consultations in Canada and Indonesia, negotiations over benefit sharing agreements are not even discussed in the Andean countries. Neither is the possibility of calling into question of the implementation of the project itself. FPIC and the possibility for communities to deny a project is not on the table. However, communities can still use consultations to mobilize and block projects by refusing to participate in them. Consequently, from an emancipatory perspective of indigenous peoples' rights there is a need to shift from a top-down to a bottom-up approach for realizing the true potentials of prior consultation and FPIC in Latin America.

\section{References}

Ahmadov, A. K. (2014). Oil, democracy, and context. Comparative Political Studies, 47(9), 1238-1267. https://doi.org/10.1177\%2F0010414013495358

Arellano-Yanguas, J. (2011). Aggravating the resource curse: Decentralisation, mining and conflict in Peru. Journal of Development Studies, 47(4), 617-638. https://doi.org/10.1080/ 00220381003706478

Baluarte, D. (2004). Balancing indigenous rights and a State's right to develop in Latin America: The inter-American rights regime and ILO Convention 169. Sustainable Development Law \& Policy, 4(2), 9-15. https://digitalcommons.wcl.american.edu/sdlp/vol4/iss2/5/ 
Barelli, M. (2012). Free, prior and informed consent in the aftermath of the UN Declaration on the rights of indigenous peoples: Developments and challenges ahead. The International Journal of Human Rights, 16(1), 1-24. https://doi.org/10.1080/13642987.2011.597746

Bebbington, A., \& Bury, J. (2013). Political ecologies of the subsoil. In A. Bebbington \& J. Bury (Eds.), Subterranean struggles: New dynamics of mining, oil, and gas in Latin America (pp. 1-25). University of Texas Press.

Blanco, C. (2016). Balance del Perú en el contexto regional: una mirada comparativa del derecho a la consulta previa con relación a Colombia, Chile y Bolivia. In K. Vargas (Ed.), La implementación del derecho a la consulta previa en el Perú. Aportes para el análisis y la garantía de los derechos colectivos de los pueblos indígena (pp. 11-27). GIZ.

Brysk, A. (2000). From tribal village to global village: Indian rights and international relations in Latin America. Stanford University Press.

Burgos, A. (2015). La implementación de la consulta previa en Ecuador en el marco de la XI Ronda Petrolera. Revista Andina de Estudios Políticos, 5(1), 47-61. https://doi. org/10.35004/raep.v5i1.109

Calle Alzate, L. (2019). Prior consultation as a scenario for political dispute. A case study among the Sikuani Peoples from Orinoquía, Colombia. In C. Wright \& A. Tomaselli (Eds.), The prior consultation of indigenous peoples in Latin America: Inside the implementation gap (pp. 91-105). Routledge.

Dargent, E., Orihuela, J. C., Paredes, M., \& Ulfe, M. E. (Eds.). (2017). Resource booms and institutional pathways: The case of the extractive industry in Peru. Latin American political economy. Palgrave Macmillan. https://doi.org/10.1007/978-3-319-53532-6

Defensoría del Pueblo del Perú. (2015). Oficio-026-2015-DP: Oficio dirigido al Ministro de Energía y Minas, Eleodoro Mayorga, en relación al D.S. No 001-2015-MEM. www. defensoria.gob.pe/modules/Downloads/documentos/Oficio-026-2015-DP.pdf

Defensoría del Pueblo del Perú. (2016). Oficio N 504-2016-DP. Oficio al Ministro de Energía y Minas sobre los procesos de consulta previa en el sector minería. www.defensoria.gob.pe/modules/Downloads/documentos/Oficio-Despacho-N-504-12-08-2016.pdf

Doyle, C. M. (2015). Indigenous peoples, title to territory, rights and resources: The transformative role of free prior and informed consent. Routledge. https://doi.org/10.4324/9781315780665

Eichler, J. (2019). Reconciling indigenous peoples' individual and collective rights: Participation, prior consultation and self-determination in Latin America. Routledge. https://doi. org/10.4324/9780367220860

El Comercio. (2013, June 11). Perú-Petro iniciará en julio 26 consultas previas en la Amazonía. http://archivo.elcomercio.pe/economia/peru/peru-petro-iniciara-julio-26-consultasprevias-amazonia-noticia-1589101

Engels, B., \& Dietz, K. (Eds.). (2017). Contested extractivism, society and the State: Struggles over mining and land. Palgrave Macmillan. https://doi.org/10.1057/978-1-137-58811-1

Falleti, T. G., \& Riofrancos, T. (2014). Participatory democracy in Latin America: The collective right to prior consultation in Ecuador and Bolivia [Conference Paper]. REPAL. http:// redeconomiapoliticaamlat.com/wp-content/uploads/2014/08/Falleti-Riofrancos_2014_ REPAL_ConsultaPrevia.pdf

Falleti, T. G., \& Riofrancos, T. (2018). Endogenous participation: Strengthening prior consultation in extractive economies. World Politics, 70(1), 86-121. https://doi.org/10.1017/ S004388711700020X

Flemmer, R. (2019). Prior consultation as a door opener: Frontier negotiations, grassroots contestation, and new recognition politics in Peru. In C. Wright \& A. Tomaselli (Eds.), The prior consultation of indigenous peoples in Latin America: Inside the implementation gap (pp. 106-118). Routledge. https://doi.org/10.4324/9781351042109-8 
Flemmer, R., \& Schilling-Vacaflor, A. (2016). Unfulfilled promises of the consultation approach: The limits to effective indigenous participation in Bolivia's and Peru's extractive industries. Third World Quarterly, 37(1), 172-188. https://doi.org/10.1080/01436597.201 5.1092867

Fontana, L. B., \& Grugel, J. (2016). The Politics of indigenous participation through "free prior informed consent": Reflections from the Bolivian case. World Development, 77, 249-261. https://doi.org/10.1016/j.worlddev.2015.08.023

Fulmer, A. M. (2014). The politics of a strange right: Consultation, mining, and indigenous mobilization in Latin America. In G. Andreopoulos \& Z. F. K. Arat (Eds.), The uses and misuses of human rights: A critical approach to advocacy (pp. 65-88). Palgrave Macmillan. https://doi.org/10.1057/9781137408341_3

Gálvez, Á., \& Sosa Villagarcia, P. (2013). "El problema del indio": una mirada a la implementación de la consulta previa desde la lógica del Estado y sus funcionarios. Revista Argumentos, 7(5), 7-15. www.revistargumentos.org.pe/mineria_conflictividad_política. html. ISSN 2076-7722

GIZ. (2015). Incorporating the human rights-based approach into resource governance projects in the context of technical cooperation. GIZ. https://rue.bmz.de/includes/downloads/GIZ_2016_ Human_Rights_in_Resource_Governance_Projects_in_Technical_Cooperation.pdf

Goodale, M. (2016). Dark matter: Toward a political economy of indigenous rights and aspirational politics. Critique of Anthropology, 36(4), 439-457. https://doi.org/10.1177/0308275x15619017

Hale, C. R. (2004). Rethinking indigenous politics in the era of the "indio permitido". NACLA Report on the Americas. Changing Identities: The Politics of Race and Globalization, Part I, 38(2), 16-21. https://doi.org/10.1080/10714839.2004.11724509

Helmke, G., \& Levitsky, S. (2006). Informal institutions and democracy: Lessons from Latin America. Johns Hopkins University Press.

Hughes, N. (2010). Indigenous protest in Peru: The "orchard dog" bites back. Social Movement Studies, 9(1), 85-90. https://doi.org/10.1080/14742830903442550

IACtHR. (2012). Case Kichwa Indigenous People of Sarayaku v. Ecuador. Fond and Reparation Payments [Caso Pueblo Indígena Kichwa de Sarayaku v. Ecuador. Fondo y Reparaciones]. Ruling 27 June 2012. San José: Inter-American Court of Human Rights. www.corteidh.or.cr/ docs/casos/articulos/seriec_245_esp.pdf.

ILO. (1989). Indigenous and tribal populations convention: Convention concerning indigenous and tribal peoples in independent countries, C169. ILO. http://ilo.org/dyn/normlex/de/f?p= 1000:12100:0::NO::P12100_INSTRUMENT_ID,P12100_LANG_CODE:312314,es:NO

ILO. (2009). Indigenous and tribal peoples' rights in practice. A guide to the ILO Convention No. 169. ILO. www.ilo.org/wcmsp5/groups/public/-dgreports/-dcomm/-publ/documents/ publication/wcms_171810.pdf

Irigoyen, M. (2016). Consulta previa en minería: algunos rasgos de la mirada empresarial. In K. Vargas (Ed.), La implementación del derecho a la consulta previa en el Perú. Aportes para el análisis y la garantía de los derechos colectivos de los pueblos indígena (pp. 191-204). GIZ.

Jaskoski, M. (2020). Participatory institutions as a focal point for mobilizing: Prior consultation and indigenous conflict in Colombia's extractive industries. Comparative Politics, 52(4), 537-556. https://doi.org/10.5129/001041520X15757670821639

Laplante, L. J., \& Spears, S. (2008). Out of the conflict zone: The case for community consent processes in the extractive sector. Yale Human Rights and Development Law Journal, 11(1), 69-116. http://digitalcommons.law.yale.edu/yhrdlj/vol11/iss1/6

La Primera. (2013, March 29). Consulta Previa, problema para el gobierno pero no para los privados. www.diariolaprimeraperu.com/online/economia/consulta-previa-problema-para-elgobierno-pero-no-para-los-privados_134808.html 
Larsen, P. B. (2016). The 'new jungle law': Development, indigenous rights and ILO Convention 169 in Latin America. International Development Policy/ Revue internationale de politique de développement. https://doi.org/10.4000/poldev.2220

Leifsen, E., Gustafsson, M.-T., Guzmán-Gallegos, M. A., \& Schilling-Vacaflor, A. (2017). New mechanisms of participation in extractive governance: Between technologies of governance and resistance work. Third World Quarterly, 38(5), 1043-1057. https://doi.org /10.1080/01436597.2017.1302329

Leifsen, E., Sánchez-Vázquez, L., \& Reyes, M. G. (2017). Claiming prior consultation, monitoring environmental impact: Counterwork by the use of formal instruments of participatory governance in Ecuador's emerging mining sector. Third World Quarterly, 38(5), 1092-1109. https://doi.org/10.1080/01436597.2017.1294980

Lévano, M. (2017). Derechos en riesgo: La lucha por la verdadera consulta a la comunidad continúa en Perú. Oxfam. https://peru.oxfam.org/blog/derechos-en-riesgo-la-lucha-por-la-verdadera-consulta-la-comunidad-contin\%C3\%BAa-en-per\%C3\%BA

Masaki, K. (2009). Recognition or misrecognition? The pitfalls of indigenous peoples' free, prior and informed consent (FPIC). In S. Hickey \& D. Mitlin, (Eds.), Rights-based approaches to development. Exploring the potentials and pitfalls (pp. 68-94). Kumarian Press.

McNeish, J.-A., Borchgrevink, A., \& Logan, O. (Eds.). (2015). Contested powers: The politics of energy and development in Latin America. Zed Books. https://doi.org/10.5040/9781350219366

Merino, R. (2018). Re-politicizing participation or reframing environmental governance? Beyond indigenous' prior consultation and citizen participation. World Development 111, 75-83. https://doi.org/10.1016/j.worlddev.2018.06.025

Merino, R. (2019). Rethinking indigenous politics: The unnoticed struggle for self-determination in Peru. Bulletin of Latin American Research, 39(4), 513-528. https://doi.org/10.1111/blar.13022

Ministerio de Cultura. (2016, September 27). Presentación ante la Comisión de Pueblos Andinos, Amazónicos y Afroperuanos, ambiente y ecología del Congreso de la República. Congreso de la República del Perú. www.congreso.gob.pe/Docs/comisiones2016/PueblosAndinosEcologia/files/ministerio_de_cultura.pdf

Montes, R. (2020, September 3). La nueva Constitución chilena debe resolver la exclusión política del pueblo mapuche. El País. http://elpais.com/internacional/2020-09-03/lanueva-constitucion-chilena-debe-resolver-la-exclusion-politica-del-pueblo-mapuche.html

Ocampo, D., \& Urrutia, I. (2016). La implementación de la consulta en el sector minero: Una mirada a los primeros procesos. In K. Vargas (Ed.), La implementación del derecho a la consulta previa en el Perú. Aportes para el análisis y la garantía de los derechos colectivos de los pueblos indígena (pp. 169-190). GIZ.

Orihuela, J. C. (2012). The making of conflict-prone development: Trade and horizontal inequalities in Peru. The European Journal of Development Research, 24, 688-705. https:// doi.org/10.1057/ejdr.2012.21

Orihuela, J. C. (2014). The environmental rules of economic development: Governing air pollution from smelters in Chuquicamata and La Oroya. Journal of Latin American Studies, 46(1), 151-183. https://doi.org/10.1017/s0022216x13001545

Republic of Peru. (2011). Law of the right to prior consultation of indigenous and tribal peoples, recognised in the Convention 169 of the International Labour Organisation (ILO), Law No. 29785, [Ley del Derecho a la consulta previa a los Pueblos Indígenas u Originarios, reconocido en el Convenio 169 de la Organización Internacional del Trabajo (OIT), Ley No. 29785]. El Peruano (separata).

Republic of Peru. (2012). Regulating Decree of Law 29785, Law of the Right to prior consultation of indigenous and tribal peoples, recognised in the Convention 169 of the International Labour Organisation (ILO), No. 001-2012-MC [Reglamento de la Ley N²9785, Ley del Derecho a 
la consulta previa a los pueblos indígenas u originarios reconocido en el Convenio 169 de la Organización Internacional del Trabajo (OIT), No. 001-2012-MC]. El Peruano (separata).

Rodríguez, G. A. (2011). Proyectos y conflictos en relación con la consulta previa. Opinión Jurídica, 10(20), 57-72. https://revistas.udem.edu.co/index.php/opinion/article/view/734

Rodríguez-Garavito, C. A. (2011). Ethnicity.gov: Global governance, indigenous peoples, and the right to prior consultation in social minefields. Indiana Journal of Global Legal Studies, 18(1), 263-305. https://doi.org/10.2979/indjglolegstu.18.1.263

Rodríguez-Garavito, C. A., Morris, M., Orduz Salinas, N., \& Buriticá, P. (2010). La consulta previa a pueblos indígenas: Los estándares del derecho internacional. Colección Justicia Global. Documento 2. Universidad de los Andes.

Schilling-Vacaflor, A. (2014). Rethinking the link between consultation and conflict: Lessons from Bolivia's gas sector. Canadian Journal of Development Studies, 35(4), 503-521. https:// doi.org/10.1080/02255189.2014.967667

Schilling-Vacaflor, A. (2017). If the company belongs to you, how can you be against it?: Limiting participation and taming dissent in neo-extractivist Bolivia. The Journal of Peasant Studies, 44(3), 658-676. https://doi.org/10.1080/03066150.2016.1216984

Schilling-Vacaflor, A., \& Eichler, J. (2017). The shady side of consultation and compensation: "Divide-and-rule" tactics in Bolivia's extraction sector. Development and Change, 48(6), 1439-1463. https://doi.org/10.1111/dech.12345

Schilling-Vacaflor, A., \& Flemmer, R. (2015). Conflict transformation through prior consultation? Lessons from Peru. Journal of Latin American Studies, 47(4), 811-839. https:// doi.org/10.1017/s0022216×15000826

Schilling-Vacaflor, A., \& Flemmer, R. (2020). Mobilising free, prior and informed consent (FPIC) from below: A typology of indigenous peoples' agency. International Journal on Minority and Group Rights, 27(2), 291-313. https://doi.org/10.1163/15718115-02702008

Schilling-Vacaflor, A., Flemmer, R., \& Hujber, A. (2018). Contesting the hydrocarbon frontiers: State depoliticizing practices and local responses in Peru. World Development, 108, 74-85. https://doi.org/10.1016/j.worlddev.2018.03.019

Sieder, R. (2011). Pueblos indígenas y derecho(s) en América Latina. In C. RodríguezGaravito (Ed.), El derecho en América Latina. Un mapa para el pensamiento jurídico del siglo XXI (pp. 303-322). Siglo Veintiuno Editores.

Svampa, M. (2015). Commodities consensus: Neoextractivism and enclosure of the commons in Latin America. South Atlantic Quarterly, 114(1), 65-82. https://doi.org/10.1215/003828762831290

Szablowski, D. (2010). Operationalizing free, prior and informed consent in the extractive industry sector? Examining the challenges of a negotiated model of justice. Canadian Journal of Development Studies, 30(1), 111-130. https://doi.org/10.1080/02255189.201 0.9669284

Tomaselli, A. (2019). Processes and failures of prior consultations with indigenous peoples in Chile. In C. Wright \& A. Tomaselli (Eds.), The prior consultation of indigenous peoples in Latin America: Inside the implementation gap (pp. 119-132). Routledge. https://doi.org/10.4324/9781351042109-9

Tomaselli, A., \& Wright, C. (2019). Introduction. In C. Wright \& A. Tomaselli (Eds.), The prior consultation of indigenous peoples in Latin America: Inside the implementation gap (pp. 1-10). Routledge. https://doi.org/10.4324/9781351042109-9

Torres Wong, M. (2018). Natural Resources, extraction and indigenous rights in Latin America: Exploring the boundaries of environmental and state-corporate crime in Bolivia, Peru, and Mexico. Routledge.

United Nations. (2007). United Nations Declaration on the rights of indigenous peoples. (UNDRIP): Adopted by the General Assembly on 13 September 2007. United Nations. 
United Nations. (2011). Guiding Principles on business and human rights: Implementing the United Nations "protect, respect and remedy" framework. United Nations. https://doi.org/10.18356/9ceabfd3-en

Urteaga-Crovetto, P. (2018). Implementation of the right to prior consultation in the Andean countries. A comparative perspective. The Journal of Legal Pluralism and Unofficial Law, 50(1), 7-30. https://doi.org/10.1080/07329113.2018.1435616

Vallejo, I. (2014). Petróleo, desarrollo y naturaleza: Aproximaciones a un escenario de ampliación de las fronteras extractivas hacia la Amazonía suroriente en el Ecuador. Anthropológica, 32(32), 115-137.

Van Cott, D. L. (2005). From movements to parties in Latin America: The evolution of ethnic politics. Cambridge University Press. https://doi.org/10.1017/CBO9780511756115

Walter, M., \& Urkidi, L. (2017). Community mining consultations in Latin America (20022012): The contested emergence of a hybrid institution for participation. Geoforum, 84, 265-279. https://doi.org/10.1016/j.geoforum.2015.09.007

World Bank. (2016). Dar más voz a los pueblos indígenas es posible. http://bancomundial.org/ es/news/feature/2016/12/21/peru-ley-consulta-previa-pueblos-indigenas

Wright, C. (2014). Indigenous mobilisation and the law of consultation in Peru: A boomerang pattern? International Indigenous Policy Journal, 5(4), 1-16. https://doi.org/10.18584/ iipj.2014.5.4.4

Wright, C., \& Tomaselli, A. (2019). From the implementation gap to indigenous empowerment: Prior consultation in Latin America. In C. Wright \& A. Tomaselli (Eds.), The prior consultation of indigenous peoples in Latin America: Inside de implementation gap (pp. 279-290). Routledge. https://doi.org/10.4324/9781351042109

Yashar, D. J. (2005). Contesting citizenship in Latin America: The rise of indigenous movements and the postliberal challenge. Cambridge University Press. https://doi.org/10.1017/ CBO9780511790966

Zaremberg, G., \& Torres Wong, M. (2018). Participation on the edge: Prior consultation and extractivism in Latin America. Journal of Politics in Latin America, 10(3), 29-58. https:// doi.org/10.1177/1866802X1801000302 


\title{
7 The curse among citizens \\ Corruption, democracy, and citizen participation in the Andean region
}

\author{
Daniel E. Moreno Morales ${ }^{1}$
}

\section{Introduction}

This chapter focuses on the relationship between the boom-post-boom cycles typical for resource-based economies, corruption, and citizens' perceptions on democratic institutions in Andean countries. I concentrate particularly on how corruption, as an informal institution that seems to be intrinsic to economic booms related to resource extraction (Dadasov et al., 2017), erodes citizen support for formal democratic institutions. This erosion can find a way of expression through declarative statements about democratic governance, but can also be expressed by a tendency among dissatisfied citizens to avoid forms of political participation that are channeled through formal democratic institutions.

While there is ample literature showing that corruption has a detrimental effect on the quality of democracy and on the legitimacy of political institutions, this subject has not been thoroughly studied under the specific dynamics of an economic boom in resource-rich nations driven by exports of extracted resources. This chapter aims to examine how the particular characteristics of a boom and post-boom cycle can set the conditions for corruption to have its perverse effect on democratic institutions. By doing so, the chapter starts a dialogue between two different and rarely interacting research agendas, one focused on the institutional legitimacy of democracy and the second on the curse of resources. Bridging these two research agendas should be useful for better understanding setbacks in democratic institutionalization as one of the less visible facets of the complex relationship between democratic institutions and a model of development based on resource exploitation.

Using recent public opinion data for Bolivia, Ecuador, Colombia, Peru, Argentina, and Chile, this chapter explores hypotheses that explain the negative effect of corruption on citizens' attitudes towards democracy, focusing on beliefs in democracy and their willingness to use its formal mechanisms-or alternative and less formal institutions - to participate. The first section presents a theoretical framework based on relevant literature on support for democracy and corruption, while the second illustrates data from on these concepts for Latin America and the Andean region for the last 15 years. The research strategy includes the statistical analyses of the relationship between perceptions of 
corruption and democratic institutions for both the individual country cases and the regional pooled database. The chapter concludes discussing how the specific characteristics of boom and, particularly, post-boom contexts could be enhancing the effect of corruption on democratic legitimacy and political participation.

\section{Support for democracy and corruption}

\section{Democracy and citizen support}

One of the main concerns of contemporary political science has to do with citizens' willingness to support democratic regimes. Scholars from different lines of research have concentrated for decades on popular support for democracy and its implications (Almond \& Verba, 1963; Easton, 1975; Inglehart \& Welzel, 2005; Welzel \& Inglehart, 2007). In order to work and to become fully consolidated, a democracy needs citizens to support it; this means that the people have to believe in democracy as the only possible way of disputing power and organizing society (Linz \& Stepan, 1996). It seems clear that democratic government requires democratic citizens, and while there is ample evidence supporting this claim (Diamond, 1999; Inglehart, 1988; Inglehart \& Welzel, 2005), there is also a wide body of research that discusses if and under what conditions support for democracy can guarantee that democracy thrives (Fuchs, 2007; Przeworski, 1991; Seligson, 2002b).

Support for democracy has different levels, arranged along a continuum that ranges from the most specific to the most diffuse. Diffuse support relates to values that intrinsically allow democracy to exist and function in a given society; in other words, democratic government requires that citizens share some basic values related to a few basic concepts, such as freedom, equality, and rule of law. This is the most indirect form of support for democracy, and has been named intrinsic support (Booth \& Seligson, 2009; Bratton \& Mattes, 2001). Values are likely to stay relatively stable across time, and while several factors affect them (including education, conflict, and regime performance), they change gradually and as part of larger societal processes (Inglehart \& Welzel, 2005).

On an intermediate point in the diffuse-to-specific continuum is support for the democratic regime. Regime support has to do with the acceptance that democracy might have some problems, but is still the best possible way of government. This Churchillian understanding of democracy as imperfect but superior to any other form of government is at the core of consolidation of democracy as the only game in town, or the restriction of the political field to only democratic principles.

Much more dependent on the context, and thus more variable across time, are the more specific forms of support for democracy. The focus of this support, rather than being the underlying democracy or the abstract idea of democracy itself, is on the people and the institutions that manage a democracy. This form of support can also include satisfaction with the way democracy works in the 
country, which is a straight-forward evaluation of regime performance. Trust in electoral authorities and trust in elections are part of these specific forms of support for democracy (Booth \& Seligson, 2009).

Participation via the formal channels that democracy offers to citizens is perhaps the most direct form of institutional acceptance. Participating in the meetings of a political party implies acceptance of this form of political participation; this implies the recognition of political parties as valid institutions for channeling participation, and the implicit assumption that representative democracy is appealing enough to engage citizens. In addition, voting in an election has value not only as a mechanism of expressing interests and deciding, but also as an almost ritualistic form of participation in the fundamental institution of democracy (Dalton, 2006).

Besides these formal mechanisms for participation, individuals can participate using informal channels. Informal political institutions are understood as the usually unwritten rules that are known by actors, guiding their behavior. Informal institutions coexist with formal rules and can shape the way in which they work (Helmke \& Levitsky, 2004), and are particularly visible in countries with low levels of democratic institutionalization (Börzel \& Risse, 2015).

It is important to keep in mind that informal mechanisms of participation are not the same as informal institutions, in the sense that they are not actual informal rules but opportunities to participate derived from such rules. Thus, using informal participatory mechanisms depends on the existence and practical relevance of set of rules that give sense to them.

Engaging in informal or alternative forms of political participation implies, at least to some extent, the acceptance of a parallel set of rules that can be as important as the formal and legally prescribed institutions. In other words, participating through informal channels means that the formal and procedural rules and mechanisms of participation are insufficient for channeling the political energy of a society. This participation is not necessarily detrimental to the formal set of participatory rules; in fact, informal rules can have a positive effect on the performance of formal institutions (Stokes, 2006).

Informal channels of participation are diverse, and they range from traditional forms of organization based on local and indigenous culture to global movements based on post-materialist demands. Many of these forms of participation are on the rise around the world, suggesting to some researchers the emergence of new forms of doing politics (Calderón, 2011). And they are in part fueled by the communication capabilities derived from the social networking applications of the Internet (what has been dubbed mass self-communication (Castells, 2009).

\section{Corruption and democratic institutions}

The relationship between corruption and democratic institutions has attracted the attention of political researchers for quite some time now (Della Porta \& Vannucci, 2012; Mungiu-Pippidi, 2006; Rose-Ackerman, 1996b), in particular with regard to developing and consolidating democracies (Della Porta \& 
Vannucci, 1999; Linz \& Stepan, 1996). Research has shown that corruption has a negative effect on the quality of democracy. Widespread corruption distorts formal institutions of democracy, producing a series of effects that result in less functional institutions and, thus, in a democracy of poorer quality (MungiuPippidi, 2006; Rose-Ackerman, 1996a, 1996b).

On the other hand, corruption affects citizens' support for democracy. ${ }^{2}$ The problem seems to be related not with the existence of corruption per se, but with the magnitude of corruption as perceived by citizens. ${ }^{3}$ The literature distinguishes between large-scale or grand corruption where politicians engage in collusion and petty corruption. While the dimension of the first is generally a matter of citizen perception dependent upon the availability of information (for instance provided by investigative journalism), petty corruption is the actual experience of corruption that citizens can have while interacting with public officials. In this form, citizens are victimized by a request to give a bribe in order to satisfactorily conclude some interaction with formal institutions (Seligson, 2006).

\section{Support for democracy and corruption in Latin America}

Citizen support for democracy has been declining around the world during the last decades (Norris, 1999; Pharr et al., 2000). Citizens are becoming more aware of the limitations and problems that are intrinsic to democratic regimes, and are growing more critical of the political system and its institutions. And this dissatisfaction often leads to the questioning of not only the individual politicians in office, but of the political system as a whole (Dalton, 2004).

For the case of Latin America, information available from different sources suggests that average support for democracy has experienced an important decline during the last few years (Cohen et al., 2017; Corporación Latinobarómetro, 2018; Zechmeister \& Lupu, 2019). Likewise, during the last decades, corruption has become a central feature of politics mainly because of its increased visibility in large-scale corruption scandals. All over the continent, former presidents and visible political leaders are facing judicial processes related to alleged - or already confirmed — corruption cases. Research has documented extensively the negative effect of these scandals on the quality of democracy and on the perceptions that citizens have about democratic institutions (Canache $\&$ Allison, 2005; Seligson, 2002a, 2006).

The Andean region has witnessed some of the most visible corruption scandals within Latin America, with deep implications for national politics in several countries. Peru is perhaps the most noticeable example, with most of this nation's living ex-presidents facing corruption allegations and judicial processes. Also, the Maduro administration in Venezuela and the government of Evo Morales in Bolivia, former president Rafael Correa in Ecuador, and Cristina Fernandez in Argentina are implicated in serious acts of corruption. As a consequence, in the Andean nations the perception of corruption as widely spread has reached a historical majority of the population. 
But the most relevant piece of information has to do with the synchronicity in the variation of support for democracy and the perception of generalized corruption. Figure 7.1 shows this relationship for the pooled database, which includes six countries in the Andean region, illustrating the change in the percentage of people that are satisfied with democracy and the percentage of the population that think that corruption is widespread in their countries. ${ }^{4}$

The cycle of the most recent boom for resource-based economies in the Andean region has seen a very particular pattern in the relationship between citizens and the state. The boom has brought along both a decline in the perception of corruption and also an increase in the satisfaction with the way democracy actually works. But this lasted only until 2012; since 2014, the perception of corruption increases, and the satisfaction with democracy decreases sharply. In 2019, the majority of individuals in the Andes are dissatisfied with democracy and think that corruption is very common among politicians in their country. Most importantly, the graph reveals that the trend for all three regions coincides with the commodities export boom cycle: Perceived corruption is lowest right when the boom reaches its peak, and then starts increasing as the bonanza period recedes.

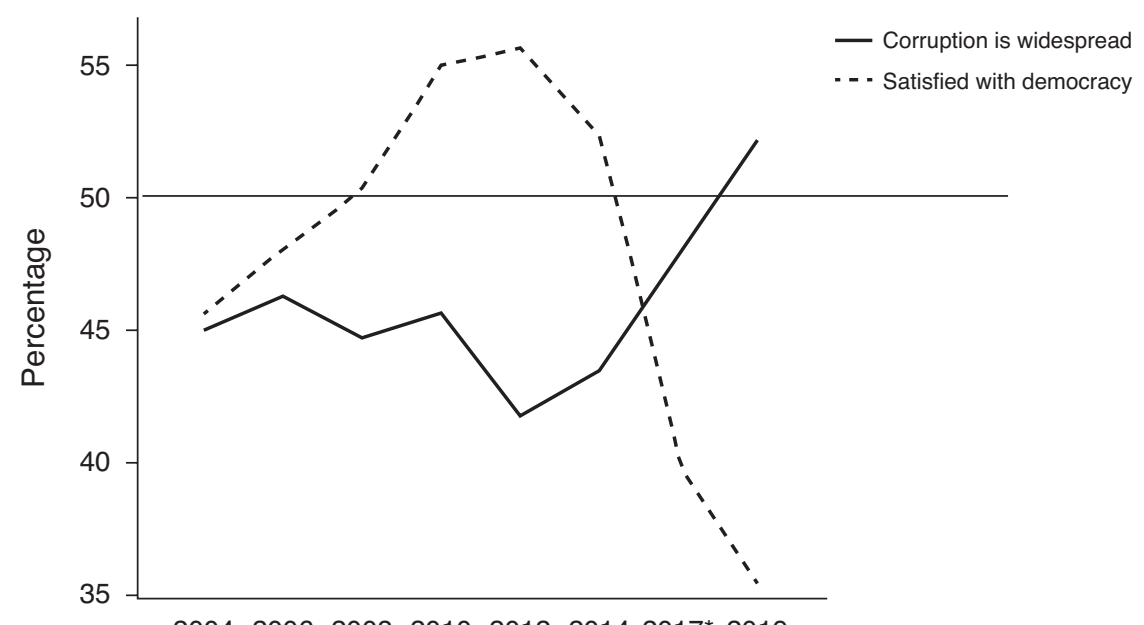

$2004200620082010201220142017^{*} 2019$

Year

*Widespread corruption question not asked in 2017

Figure 7.1 Percentage of people who feel satisfied with how democracy works in their country and percentage who think corruption is very common among politicians in the Andean region, 2004-2019

Source: The AmericasBarometer by the Latin American Public Opinion Project (LAPOP), www.LAPOPSurveys.org. 2004-2019 


\section{Research strategy}

The perception of corruption in Andean countries has increased significantly as the commodity-export boom cycle ended. What is the effect that perceived corruption has on citizens' beliefs in democratic institutions in the Andean region?

The empirical analysis focuses on the more specific forms of support for democracy: regime support, satisfaction with democracy, and trust in elections. ${ }^{5}$ Participation through formal and informal institutions is also considered, assuming that they are more likely to be affected by corruption perceptions or experience than actual democratic values. ${ }^{6}$

Given this, this work attempts to contribute with answers to three specific empirical questions, with a focus on the Andean region marked by a generalized perception of corruption coinciding with the post-boom: First, does corruption affect democratic legitimacy? Second, does corruption affect the chance that a person engages in both formal and informal ways of political participation? And third, can we speak of new or emerging forms of relationship between citizens and the state that are less formal as a result of corruption?

The hypotheses guiding this work are based on the understanding that democracy is sensitive to the performance of the political regime, and that the consolidation of corruption as a stable yet dysfunctional relationship between society, the market and the state will have an effect on both citizens' beliefs and practices towards democracy.

The former can be translated into three different specific hypotheses:

1 Corruption should have a detrimental effect on support for democracy, with individuals who perceive that corruption is generalized among politicians less willing to support a democratic regime.

2 Individuals who perceive that corruption is more generalized are likely to be less eager to engage in the formal ways of political participation offered by the political system.

3 Individuals who perceive more corruption engage more commonly in less formal ways of participation, such as protests and public demonstrations as alternative means of expressing their dissatisfaction with the system.

This project uses survey data from the Latin American Public Opinion Project (LAPOP) and specifically from their 2018-2019 round of surveys within the AmericasBarometer ${ }^{7}$

Data from six countries are employed in analyses both for each individual country and using a multi-country pooled database with a total of 9,565 observations. Individual country samples are representative of the national population in voting age, and range from 1,521 to 1,683 observations collected in national surveys conducted between 2018 and 2019. The countries included are Argentina, Bolivia, Colombia, Chile, Ecuador, and Peru. Chile and Argentina add variability and contrast to the four Andean countries, allowing for a wider test of the hypotheses, without losing the capability of identifying particular context-specific aspects of each country in the discussion of the findings. ${ }^{8}$ 
A series of multivariate statistical models were fitted on the data in order to estimate the independent effect of corruption. ${ }^{9}$ The methodological strategy includes the fitting of the models both using the multi-country pooled database, which allows to identify effects that could be deemed as general for the Andean region, and the specific individual country datasets, in the attempt to identify particular trends for each country.

\section{Variable operationalization}

Democratic legitimacy is understood with a theoretical approach that distinguishes between different levels of citizens' support for democracy along a continuum that ranges from diffuse to specific. Three different measures of support for democracy are employed as dependent variables in the analyses: One focuses on support for the democratic regime; the second measure taps more into regime performance, which is operationalized through the standard question of satisfaction with democracy; and the third variable employed in the study is trust in elections.

Participation via formal institutional mechanisms is operationalized with two items: whether the person sympathizes with a political party and if the person does intend to vote in the next national elections. Engagement in informal mechanisms of political participation is measured with two different variables: one that registers whether the person participated lately in a public protest or demonstration; a second one that asks whether the person engages in community based voluntary activities.

Corruption, the main independent variable, is measured by two variables that tap into different dimensions of corruption. First, the perception of how generalized corruption is in the country, ${ }^{10}$ and second, the actual experience of corruption that the person has had during the last year (whether the person was a victim of a bribe request by a public official during the last 12 months). ${ }^{11}$ The actual wording of the questions employed for all dependent and the main independent variables is included in the annex.

Additional independent variables included in the models as statistical controls are: the individual's approval of the president, ${ }^{12}$ an index for general support for the political system, ${ }^{13}$ level of education, trust in the media, the socioeconomic level measured in quintiles defined by the availability of capital goods in the household, the highest level of education attained by the person, the retrospective perception of the individual's personal economy, and the person's sense of physical insecurity at their neighborhood or community.

\section{Results}

\section{H1. Corruption reduces support for democracy}

The first hypothesis suggests that perceived corruption decreases citizens' support for democratic rule. As mentioned before, the three different dependent variables defined for measuring support for democracy are regime support, satisfaction with democracy, and trust in elections. Table 7.1 presents the independent effects for each of these variables. 
Table 7.1 Summary of independent effects from regression models for regime support

\begin{tabular}{|c|c|c|c|c|c|c|c|}
\hline Variable/Country & Colombia & Ecuador & Bolivia & Peru & Chile & Argentina & Pooled DB \\
\hline $\begin{array}{l}\text { Corruption } \\
\text { perception }\end{array}$ & & & & & --- & --- & --- \\
\hline \multicolumn{8}{|l|}{$\begin{array}{l}\text { Corruption } \\
\text { victimization }\end{array}$} \\
\hline $\begin{array}{l}\text { Presidential } \\
\text { approval }\end{array}$ & +++ & & +++ & ++ & & ++ & +++ \\
\hline $\begin{array}{l}\text { Trust in the } \\
\text { media }\end{array}$ & +++ & ++ & +++ & ++ & ++ & & +++ \\
\hline Education & +++ & & + & ++ & & +++ & +++ \\
\hline Gender (female) & --- & & --- & & & & --- \\
\hline Wealth quintiles & + & & & ++ & & ++ & +++ \\
\hline $\begin{array}{l}\text { Personal } \\
\text { economy perc. }\end{array}$ & & & & & - & & --- \\
\hline \multirow[t]{2}{*}{ Insecurity } & & & & --- & - & & --- \\
\hline & 772 & 704 & 761 & 701 & 745 & 718 & 4,401 \\
\hline
\end{tabular}

Source: Lapop AB 2018-9; ++ +/-- - p<.01; + +/- - - p <.05; +/- - - p<.1

Table 7.2 Summary of independent effects from regression models for satisfaction with democracy

\begin{tabular}{|c|c|c|c|c|c|c|c|}
\hline Variable/Country & Colombia & Ecuador & Bolivia & Peru & Chile & Argentina & Pooled DB \\
\hline $\begin{array}{l}\text { Corruption } \\
\text { perception }\end{array}$ & - & --- & & & --- & --- & --- \\
\hline $\begin{array}{l}\text { Corruption } \\
\text { victimization }\end{array}$ & - & & & & & & \\
\hline System support & +++ & +++ & +++ & +++ & +++ & +++ & +++ \\
\hline $\begin{array}{l}\text { Presidential } \\
\text { approval }\end{array}$ & +++ & +++ & +++ & +++ & & +++ & +++ \\
\hline \multicolumn{8}{|l|}{$\begin{array}{l}\text { Trust in the } \\
\text { media }\end{array}$} \\
\hline Education & & --- & --- & & & & --- \\
\hline Gender (female) & - & & --- & & & & --- \\
\hline Wealth quintiles & & & - & - & & & \\
\hline $\begin{array}{l}\text { Personal } \\
\text { economy perc. }\end{array}$ & & & & & - & & --- \\
\hline Insecurity & & & & --- & - & - & --- \\
\hline $\mathrm{N}$ & 769 & 698 & 752 & 693 & 754 & 717 & 4,383 \\
\hline
\end{tabular}

Source: Lapop AB 2018-9; + + +/-- - p<.01; + +/- - - p $<.05 ;+/---\mathrm{p}<.1$

Corruption is found to have a negative effect on support for a democratic regime, though this effect is limited. While its negative effect is highly significant in the pooled database (representing the combined population of the Andean region) and in Chile and Argentina, perception of corruption is not significant in the other four countries, once all other factors are controlled for. 
Table 7.3 Summary of independent effects from regression models for trust in elections

\begin{tabular}{|c|c|c|c|c|c|c|c|}
\hline Variable/Country & Colombia & Ecuador & Bolivia & Peru & Chile & Argentina & Pooled DB \\
\hline $\begin{array}{l}\text { Corruption } \\
\text { perception }\end{array}$ & --- & --- & & & --- & --- & --- \\
\hline \multicolumn{8}{|l|}{$\begin{array}{l}\text { Corruption } \\
\text { victimization }\end{array}$} \\
\hline System support & +++ & +++ & +++ & +++ & +++ & +++ & +++ \\
\hline $\begin{array}{l}\text { Presidential } \\
\text { approval }\end{array}$ & +++ & + & +++ & ++ & +++ & +++ & +++ \\
\hline $\begin{array}{l}\text { Trust in the } \\
\text { media }\end{array}$ & +++ & +++ & +++ & +++ & +++ & +++ & +++ \\
\hline Education & & --- & --- & + & & +++ & \\
\hline Gender (female) & --- & --- & & --- & & --- & --- \\
\hline Wealth quintiles & & & & & ++ & ++ & +++ \\
\hline $\begin{array}{l}\text { Personal } \\
\text { economy perc. } \\
\text { Insecurity }\end{array}$ & & & --- & - & & & \\
\hline $\mathrm{N}$ & 774 & 707 & 768 & 703 & 786 & 717 & 4,437 \\
\hline
\end{tabular}

Source: Lapop AB 2018-9; + + +/- - - p <.01; + +/- - - p $<.05 ;+/---\mathrm{p}<.1$

In addition, having been a victim of corruption by a public official has no effect whatsoever on regime support.

When a more contextually dependent variable such as satisfaction with democracy is considered, the perception of the generalization of corruption among politicians has a clearer negative effect. Not only the pooled database with its larger number of observations shows a significant effect, but also four out of six of the individual countries included share this result. In fact, satisfaction with democracy (measured in a 0 to 100 scale) is 20 points lower for those who believe that all politicians are involved with corruption when compared to those who believe that only a few are. Only in Bolivia and Peru are corruption perceptions not related with lower levels of satisfaction with democracy. And again, corruption victimization has no effect on satisfaction with democracy, other than a minor mild effect in Colombia.

When trust in elections is considered as the dependent variable, results are very similar to when satisfaction with democracy is the focus. Perception of generalized corruption has a strong statistical effect when the pooled data are considered (on average in the region there is a 22-point gap between those who believe that corruption affects only a few politicians versus those who think it involves most or all), but corruption victimization does not affect confidence in elections. But this does not happen in Bolivia nor Peru, where confidence in elections does not seem to depend at all on corruption.

\section{H2. Corruption reduces engagement in formal participation mechanisms}

The second hypothesis posits that high levels of perceived corruption should have a negative effect on the likelihood that a person participates using the formal mechanisms available in a democracy. The two formal participation mechanisms considered here are sympathizing with a political party and abstaining 
from voting in the next national elections. Tables 7.4 and 7.5 present results from logistic regression models fitted on the data for these two items.

Having a sympathetic relationship with a political party seems to be the variable least affected by corruption among all dependent variables considered here. Only in Argentina does the perception of corruption decrease the chance

Table 7.4 Summary of independent effects from logistic regression models for sympathizing with a political party

\begin{tabular}{|c|c|c|c|c|c|c|c|}
\hline Variable/Country & Colombia & Ecuador & Bolivia & Peru & Chile & Argentina & Pooled DB \\
\hline $\begin{array}{l}\text { Corruption } \\
\text { perception }\end{array}$ & & & & & & --- & --- \\
\hline $\begin{array}{l}\text { Corruption } \\
\text { victimization }\end{array}$ & & & & + & & & ++ \\
\hline Regime support & +++ & & & & +++ & +++ & +++ \\
\hline $\begin{array}{l}\text { Presidential } \\
\text { approval }\end{array}$ & & & +++ & & & --- & \\
\hline \multicolumn{8}{|l|}{$\begin{array}{l}\text { Trust in the } \\
\text { media }\end{array}$} \\
\hline Education & & & & --- & & & - \\
\hline Gender (female) & --- & - & & & & & --- \\
\hline Wealth quintiles & & & & & +++ & ++ & + \\
\hline \multicolumn{8}{|l|}{$\begin{array}{l}\text { Personal } \\
\text { economy perc. }\end{array}$} \\
\hline Insecurity & & --- & & - & & & - \\
\hline $\mathrm{N}$ & 769 & 700 & 758 & 700 & 744 & 718 & 4,437 \\
\hline
\end{tabular}

Source: Lapop AB 2018-9; + + +/-- - p<.01; + +/- - - p <.05; +/- - - p<.1

Table 7.5 Summary of independent effects from logistic regression models for willingness to vote

\begin{tabular}{|c|c|c|c|c|c|c|c|}
\hline Variable/Country & Colombia & Ecuador & Bolivia & Peru & Chile & Argentina & Pooled DB \\
\hline $\begin{array}{l}\text { Corruption } \\
\text { perception }\end{array}$ & & & & & --- & --- & --- \\
\hline \multicolumn{8}{|l|}{$\begin{array}{l}\text { Corruption } \\
\text { victimization }\end{array}$} \\
\hline Regime support & & & + & & ++ & & \\
\hline \multicolumn{8}{|l|}{$\begin{array}{l}\text { Presidential } \\
\text { approval }\end{array}$} \\
\hline \multicolumn{8}{|l|}{$\begin{array}{l}\text { Trust in the } \\
\text { media }\end{array}$} \\
\hline Education & & ++ & & +++ & & +++ & +++ \\
\hline Gender (female) & & & & ++ & & & \\
\hline Wealth quintiles & & --- & & & & & \\
\hline \multicolumn{8}{|l|}{$\begin{array}{l}\text { Personal } \\
\text { economy perc. }\end{array}$} \\
\hline Insecurity & & & & & - & & - \\
\hline $\mathrm{N}$ & 744 & 696 & 685 & 679 & 703 & 673 & 4,180 \\
\hline
\end{tabular}

Source: Lapop AB 2018-9; + + +/- - - p<.01; + +/- - - p <.05; +/- - - p <.1 
that a person sympathizes with a political party, and having been a victim of corruption only has a mild positive effect in Peru.

Willingness to vote in the next national election (if they were held this coming weekend, as opposed to abstaining from voting) is negatively affected by the perception of corruption in Chile and in Argentina, as well as in the six-country pooled database. The decision of whether to vote or not does not seem to be affected by either the perception of corruption or the practical experience with it in the Andean region.

\section{H3. Corruption increases engagement in informal participation mechanisms}

The third hypothesis argues that the effects of corruption on political institutions go beyond formal institutions and fuel participation in informal institutions. The final analyses, thus, explore whether corruption has any effect on voluntary engagement in community activities and on participation in public protests and demonstrations. Tables 7.6 and 7.7 present summarized results for these analyses.

Once other factors are controlled for, perception of corruption was found to have a mild and partial negative effect on the probability that a person engages in community activities (it is only significant in Argentina, Bolivia, and Peru). But having been a victim of corruption surprisingly increases this probability, with a significant positive effect in all six countries considered individually and in the pooled database.

Similar to community activities, those who have been requested a bribe by a public official are more likely to engage in protests and public demonstrations

Table 7.6 Summary of independent effects from logistic regression models for voluntary engagement in community activities

\begin{tabular}{|c|c|c|c|c|c|c|c|}
\hline Variable/Country & Colombia & Ecuador & Bolivia & Peru & Chile & Argentina & Pooled DB \\
\hline $\begin{array}{l}\text { Corruption } \\
\text { perception }\end{array}$ & & & - & - & & --- & --- \\
\hline $\begin{array}{l}\text { Corruption } \\
\text { victimization }\end{array}$ & + & +++ & +++ & + & +++ & +++ & +++ \\
\hline Regime support & & & & & & - & \\
\hline $\begin{array}{l}\text { Presidential } \\
\text { approval }\end{array}$ & ++ & & ++ & & +++ & & +++ \\
\hline $\begin{array}{l}\text { Trust in the } \\
\text { media }\end{array}$ & + & + & & ++ & & ++ & +++ \\
\hline Education & & & - & --- & & & --- \\
\hline Gender (female) & ++ & ++ & ++ & +++ & +++ & +++ & +++ \\
\hline Wealth quintiles & --- & & & & & --- & --- \\
\hline $\begin{array}{l}\text { Personal } \\
\text { economy perc. } \\
\text { Insecurity }\end{array}$ & & --- & + & ++ & & & ++ \\
\hline $\mathrm{N}$ & 744 & 696 & 685 & 679 & 703 & 673 & 4,180 \\
\hline
\end{tabular}

Source: Lapop AB 2018-9; ++ +/ - - - p <.01; ++/- - -p<.05; +/- - -p<.1 
Table 7.7 Summary of independent effects from logistic regression models for protest participation

\begin{tabular}{|c|c|c|c|c|c|c|c|}
\hline Variable/Country & Colombia & Ecuador & Bolivia & Peru & Chile & Argentina & Pooled DB \\
\hline $\begin{array}{l}\text { Corruption } \\
\text { perception }\end{array}$ & & & & & & --- & \\
\hline $\begin{array}{l}\text { Corruption } \\
\text { victimization }\end{array}$ & ++ & ++ & +++ & +++ & +++ & ++ & +++ \\
\hline Regime support & & & & & & ++ & +++ \\
\hline $\begin{array}{l}\text { Presidential } \\
\text { approval }\end{array}$ & --- & & & & --- & --- & --- \\
\hline $\begin{array}{l}\text { Trust in the } \\
\text { media }\end{array}$ & & & & & --- & - & \\
\hline $\begin{array}{l}\text { Education } \\
\text { Gender (female) }\end{array}$ & +++ & & & & +++ & $\begin{array}{l}+++ \\
++\end{array}$ & +++ \\
\hline Wealth quintiles & & & + & + & & & ++ \\
\hline $\begin{array}{l}\text { Personal } \\
\text { economy perc. } \\
\text { Insecurity }\end{array}$ & & & & & & & \\
\hline $\mathrm{N}$ & 771 & 701 & 760 & 701 & 745 & 717 & 4,395 \\
\hline
\end{tabular}

Source: Lapop AB 2018-9; + + +/- - -p <.01; + +/- - -p<.05; +/- - -p<.1

than individuals that have not been exposed to this form of corruption. And perceiving that corruption is generalized fails to have an effect on protest participation anywhere except Argentina.

\section{Discussion}

The results presented in this study offer an ample array of implications about the effects of corruption on democratic institutions and participation under economies that are booming as a result of an international market avid of commodities. First, it is important to point out that both support for the political system and perceptions of corruption change during the post-boom period. During the good times, average levels of democratic legitimacy in the Andean region not only remained high but kept increasing until reaching a peak in 2012. Conversely, the share of the population in the six-country aggregate sample who believed that corruption was widespread reached its lowest in 2012, after a continuous decline during the previous years. After that the trend reversed, and citizens began to feel less satisfied with democracy and more convinced that corruption was institutionalized since 2014, and by 2019 showed historically extreme values.

Is there a causal relationship between the loss in system support and the receding of the resource-export cycle? The information presented here suggests that this is at least a plausible hypothesis, identifying a correlation between the moments in which system support declines and the resource cycle ebbs. Corruption seems to be an intervening variable associated with both the end of the economic cycle and the erosion of democratic legitimacy, but it is not self-evident how this works. 
The following paragraphs discuss possible answers for these questions, considering both evidence that confirms the hypotheses and that raises questions about them.

The results of the analyses presented here show that corruption has a relevant effect on the more specific forms of support for democracy: both satisfaction with the way democracy works and trust in elections depend significantly on the perception of how generalized corruption is among politicians. The more widespread corruption is to the eyes of citizens, the less legitimate a democracy is when its most distinctive institution (elections) is considered.

However, there is an interesting variation in the effect of corruption on support for the democratic regime. While the effect is evident and statistically robust in Chile and Argentina (and the pooled six-country database that represents the combined population of the Andean region), it is far less definitive in the other four countries considered individually, where the basic belief that democracy is the best form of government does not depend on the perception of corruption once all other factors are controlled for.

As part of the same variation, the effect of perceived corruption on support for democracy is clear across the region, but it fails to have an independent effect on any of the variables that measure this support in Bolivia and in Peru. Societies in these two Andean countries seem to be more impervious to corruption, and neither its perception or its actual experience affects the evaluation they make of the political system. It is not clear at this point why corruption fails to affect support for democracy in these two countries at the same time that it has such a significant effect elsewhere. Perhaps it has to do with the fact that corruption victimization is higher in these countries than in the other countries included in the analyses (though Ecuador has similar figures as Peru, with Bolivia leading by far with more than twice the percentage of people victimized by corruption in Argentina and six times the percentage in Chile). This could mean that societies are more used to corruption and thus less affected by it.

The other way in which corruption is measured here, whether the person was recently a victim of a bribe request from a public official, does not seem to have any significant independent effect on support for democracy. Citizens' evaluations of democracy do not depend on their actual experience with corruption expressed as bribery, but on their perceptions of corruption among politicians. In that sense, it is large-scale corruption, with their prime-time media diffusion, that affects democracy, not the form of corruption to which citizens are directly exposed to (petty corruption).

The second hypothesis discussed in this paper suggests that corruption should have a detrimental effect on the probability that a person opts to participate in formal institutional politics through the formal mechanisms available within a democracy. Exercising the right to vote and participating in (or at least sympathizing with) a political party are the indicators used for the analyses. This hypothesis finds weak support in the cases studied here; with the exception of Argentina, where the data show the expected relationships, and partially in Chile, corruption does not affect engagement in formal institutions.

The lack of a significant effect, however, might have to do with particular characteristics of the dependent variables, and not necessarily with the actual 
effect of corruption on institutions: Voting is compulsory in Bolivia, Ecuador, Peru, and Argentina, so the "might not vote" has a less clear meaning. ${ }^{14}$ Under a context of compulsory voting, this variable does not seem to be the best measure of support for democratic institutions. It is relevant, however, that perceived corruption has a negative effect in Chile, precisely one of the two countries in which voting is optional.

Sympathizing with a political party is not deterred by the perception of corruption, despite the fact that this is a voluntary activity in all countries. Only in Argentina does the probability of sympathizing with a party decrease with perceived corruption. A plausible explanation would point at the possibility that individuals do not see engagement with a political party as an act of faith in the democratic system, and conceive it more in practical terms as a means of attaining some particular goals or interests. This is almost the exact definition of a clientelistic linkage between parties and voters (Kitschelt, 2000).

It is more interesting to observe the results of this research related with the effect that corruption has on citizens' participation in informal institutions. In contrast with what happens with support for democracy, what mobilizes participation through informal mechanisms is not the perception of how generalized corruption is, but actual personal experience with it through bribe solicitation. While perception of large-scale corruption affects the legitimacy of the democratic system and its institutions, the actual practices of petty corruption increase participation in protests and in community activities (with the exception of Argentina). Corruption victimization increases the probability that a person participates in protests and in community activities, once every other factor is held constant.

There are two possible explanations for this. First, the experience of corruption causes a sense of malaise among people and that leads them to react against formal institutions, engaging in contentious forms of participation. This is a plausible explanation, particularly for the variable that measures participation in protests and demonstrations, and is consistent with an explanation of participation in protests as a form of dissatisfaction with the political system (Christensen, 2016; Morlino \& Tarchi, 1996).

But the explanation that points at a sense of malaise with the political system seems to have less capacity to explain the second form of participation through informal institutions, which is engagement in community activities. Why would people who have suffered a bribe solicitation engage more in community activities? Because they have lost faith and confidence in formal institutions? That does not necessarily have to be the case. It is also possible that there are some individuals that are simply more active and get in contact with different institutions, and that is why they engage more in community activities and are more exposed to corruption (so both variables depend on some other factor not considered in the equation).

\section{Conclusion}

The resource curse theory predicts an increase of corruption in booming economies dependent upon the export of natural resources. Increased corruption affects the quality of democracy, by reducing citizen support and political 
participation, as an ample body of literature demonstrates. This chapter shows that there is strong empirical evidence from the Andean region supporting these claims over time, suggesting that the malaise brought aside by corruption is installed among citizens in form of negative feelings towards the political system.

Support for democracy and its institutions has seen important declines during the last few years in Latin America. Citizens throughout the region are growing warier of the political system and of those in charge of it, with a sense of dissatisfaction that exceeds discontent with individual politicians and reaches the core of democratic support. While support for democracy has been declining around the world during the last decade, in Latin America the pattern suggests a reversion of a trend that showed an increase in support during the good years of the export-boom cycle. A similar but inverse trend can be found in the perception of corruption, which has increased significantly across the region as soon as the commodity-export tide started retreating.

This raises a relevant new angle for research on the resource curse: The decline in political support and the increase of perceived corruption take place when the export-boom cycle starts to ebb and recede, not during its peak as it could be expected from the extant literature. This implies that the negative institutional effects of the resource curse are a by-product and aftereffect of a boom cycle, and not a direct part of it. This seems to be the case at least in the Andean region during the latest cycle and might be explained by different factors, including a likely shrinking of the benefits distributed via both corrupt and legal practices.

The data analyzed here suggest that corruption acts on the way citizens relate with democratic institutions in at least two different ways: First, the perception of corruption as a common attribute among politicians reduces support for the political system, affecting both trust in elections and satisfaction with how the political system is currently working in the country. Second, actual experience with corruption increases the chances that a person participates in a public demonstration or engages with other citizens in order to solve problems in the community or doing other community-based activities.

While large-scale corruption is different than the petty corruption to which citizens are directly exposed to, they both reflect a problematic way in which politicians and bureaucrats can take advantage of their position in the state. If both forms of corruption are large in magnitude and perceived as such by the majority of citizens, then support for democracy and its institutions can be expected to decrease, while informal ways of participating can be expected to increase.

While this study does not prove that there is a causal link between the end of an economic commodity-export cycle, an increase in perceived corruption and a decrease in support for democratic institutions, the information analyzed in this chapter shows that this is a plausible relationship. Further research focusing specifically on this question could add valuable knowledge on this issue. What the data clearly shows is that corruption and system support are strongly related to each other. Thus, corruption might be seen as an economic boom's curse on democratic legitimacy in resource-dependent contexts. 


\section{Appendix 1}

\section{Variable operationalization: questions used for main variables}

\begin{tabular}{|c|c|c|}
\hline Variable & Question & Coding treatment \\
\hline \multicolumn{3}{|c|}{ Dependent variables (support for democracy) } \\
\hline $\begin{array}{l}\text { Support for the } \\
\text { democratic regime }\end{array}$ & $\begin{array}{l}\text { Democracy may have } \\
\text { problems, but it is better } \\
\text { than any other form of } \\
\text { government. To what extent } \\
\text { do you agree or disagree with } \\
\text { this statement? }\end{array}$ & $\begin{array}{l}1 \text { thru } 7 \text { original scale } \\
\text { recoded into } 0 \text { to } 100 \text { scale } \\
\text { for analyses }\end{array}$ \\
\hline $\begin{array}{l}\text { Satisfaction with } \\
\text { democracy }\end{array}$ & $\begin{array}{l}\text { In general, would you say that } \\
\text { you are very satisfied, satisfied, } \\
\text { dissatisfied or very dissatisfied } \\
\text { with the way democracy } \\
\text { works in (Country)? }\end{array}$ & $\begin{array}{l}\text { Recoded into a } 0 \text { to } 100 \\
\text { scale for multivariate analysis } \\
\text { and in satisfied/dissatisfied } \\
\text { dichotomous for graphs }\end{array}$ \\
\hline Trust in elections & $\begin{array}{l}\text { To what extent do you trust } \\
\text { elections in this country? }\end{array}$ & $\begin{array}{l}1 \text { thru } 7 \text { original scale } \\
\text { recoded into } 0 \text { to } 100 \text { scale } \\
\text { for analysis }\end{array}$ \\
\hline $\begin{array}{l}\text { Sympathy for political } \\
\text { party }\end{array}$ & $\begin{array}{l}\text { Do you currently identify } \\
\text { with a political party? }\end{array}$ & Original dichotomous yes/no \\
\hline Willingness to vote & $\begin{array}{l}\text { If the next general elections } \\
\text { were being held this week, } \\
\text { what would you do? (1) } \\
\text { Wouldn't vote (2) Would vote } \\
\text { for the current (incumbent) } \\
\text { candidate or party (3) Would } \\
\text { vote for a candidate or party } \\
\text { different from the current } \\
\text { administration (4) Would } \\
\text { go to vote but would leave } \\
\text { the ballot blank or would } \\
\text { purposely cancel my vote }\end{array}$ & $\begin{array}{l}\text { All options other than } \\
\text { wouldn't vote coded } \\
\text { positively in dichotomous } \\
\text { variable }\end{array}$ \\
\hline $\begin{array}{l}\text { Participation in public } \\
\text { protests }\end{array}$ & $\begin{array}{l}\text { In the last } 12 \text { months, } \\
\text { have you participated in a } \\
\text { demonstration or protest } \\
\text { march? }\end{array}$ & Original dichotomous yes/no \\
\hline
\end{tabular}


(Continued)

\begin{tabular}{|c|c|c|}
\hline Variable & Question & Coding treatment \\
\hline $\begin{array}{l}\text { Engagement in } \\
\text { community activities }\end{array}$ & $\begin{array}{l}\text { I am going to read you a list } \\
\text { of groups and organizations. } \\
\text { Please tell me if you attend } \\
\text { meetings of these organizations } \\
\text { at least once a week, once or } \\
\text { twice a month, once or twice } \\
\text { a year, or never. Meetings of } \\
\text { a community improvement } \\
\text { committee or association? }\end{array}$ & $\begin{array}{l}\text { At least once a week and } \\
\text { once or twice a month coded } \\
\text { positively in dichotomous } \\
\text { variable }\end{array}$ \\
\hline \multicolumn{3}{|c|}{ Independent variables (corruption) } \\
\hline $\begin{array}{l}\text { Generalization of } \\
\text { corruption }\end{array}$ & $\begin{array}{l}\text { Taking into account your own } \\
\text { experience or what you have } \\
\text { heard, corruption among public } \\
\text { officials is: (1) Very common (2) } \\
\text { Common (3) Uncommon or } \\
\text { (4) Very uncommon? }\end{array}$ & $\begin{array}{l}\text { Recoded into a } 0 \text { to } 100 \text { scale } \\
\text { for multivariate analysis and } \\
\text { in very common vs other } \\
\text { options dichotomous for } \\
\text { graphs }\end{array}$ \\
\hline $\begin{array}{l}\text { Corruption } \\
\text { victimization }\end{array}$ & $\begin{array}{l}\text { During the last } 12 \text { months } \\
\text { has been asked for a bribe } \\
\text { by: a government employee, } \\
\text { a police officer, the military, } \\
\text { municipality, at work, at the } \\
\text { courts, at a public health } \\
\text { service, at a public school }\end{array}$ & $\begin{array}{l}\text { Dichotomous variable } \\
\text { coded positively if any bribe } \\
\text { solicitation took place }\end{array}$ \\
\hline
\end{tabular}

Source: The AmericasBarometer by the Latin American Public Opinion Project (LAPOP), www. LapopSurveys.org. 2004-2019

\section{Notes}

1 This chapter benefitted from valuable and patient comments by Gerardo Damonte, Bettina Schorr, and Paul Talcott. Errors and omissions are only the author's responsibility. Part of this research was conducted during a post-doctoral research fellowship granted by trAndeS at PUCP in Lima, during 2019.

2 While corruption usually reduces the legitimacy of a political system, it does not always work that way. For instance, in countries with weak institutions and clientelistic governments, citizens can tend to support corrupt government because it offers some predictability (Manzetti \& Wilson, 2007). It has also been shown that corruption can sometimes work as oil for moving a slow and ineffective bureaucracy (Kaufmann, 1997), but despite these facts, corruption has a negative general balance for democracy.

3 If corruption is widespread but no one is aware of it, support for the political system is unlikely to decline as a direct result of it.

4 Lines represent the percentage of people who a) feel satisfied with democracy and b) perceive that corruption is very widespread, averaging results for six countries: Colombia, Ecuador, Peru, Bolivia, Argentina, and Chile, between 2004 and 2019.

5 While the perception of corruption also has consequences for trust in the rule of law and for the broader perspective of democratic rule (Heidenheimer, 2002; Lapalombara, 1994), this chapter limits its analysis to more-specific democratic institutions.

6 The analyses consider two different yet related informal channels of participation for which data are available. One is participation in community-based activities, and the other 
is participation in public protests or demonstrations. Both have to do with the strength of civil society and its capacity to mobilize and act on an institutional basis that is not statedbased and is not formal, and they are both relevant to this paper in that they reflect a logic of participation that takes place outside the realm of the formal democratic institutions. Both are part of a cluster of attitudes that is based on informal institutions as opposed to those formal mechanisms provided as means of participation by the political system.

7 LAPOP is a project well-known for producing high-quality comparative survey data from most countries in the Americas, and its AmericasBarometer is a survey conducted approximately every two years on nationally representative probabilistic samples in each country across the region. The 2018-9 round is the latest available dataset at their repository. All the data employed here are publicly and freely available at LAPOP's website (www.lapopsurveys.org), which also includes different studies and additional information on the data. I thank LAPOP and its major donors for making these data available.

8 Venezuela was excluded from the study as the latest round of LAPOP's AmericasBarometer could not be conducted in this country due to the political instability and current social conditions in this country.

9 All models employ robust standard errors that account for the effect of sampling design (Kish \& Frankel, 1974; Knott, 1991; Rust, 1985).

10 The 2018-2019 round of the AmericasBarometer included two slightly different questions for measuring perception of corruption in a split-sample setting. Assuming that the differences in the wording of the questions were insubstantial to the results, I used both questions for the analyses with almost identical results, but reported only one of them.

11 While a high correlation between these variables could be expected in theory, the correlation is in fact strikingly low (.09). This means that the two variables are found to be in fact independent; in other words, corruption among politicians is independent of the actual victimization that citizens experience during their exchanges with the state.

12 Approval of the president is a usual control variable for the individual's personal evaluation of the government. While it is negatively correlated with perception of corruption $(-.24)$, the relationship is low enough to avoid a multicollinearity problem in the statistical models.

13 This variable is included as a statistical control in an attempt to control for the fact that some individuals tend to have a more positive view of the political system in general, which might explain some of their support for democracy, particularly at the most specific level. This statistical control was included in the models for satisfaction with democracy and trust in elections.

14 In fact, $70 \%$ of all respondents in the pooled database that say that they will not vote in the next elections are in either Chile or Colombia, the two countries where voting is not compulsory. The proportion of people that say that they will not vote in Bolivia or Ecuador is minimal (less than 5\% in each case). However, the relationship between compulsory voting laws and voter turnout in Latin America has demonstrated to be less straight-forward than expected (Carreras, 2016; Fornos et al., 2004; Haime, 2017).

\section{References}

Almond, G., \& Verba, S. (1963). The civic culture. Princeton University Press. https://doi. org/10.1515/9781400874569

Booth, J., \& Seligson, M. (2009). The legitimacy puzzle in Latin America: Democracy and political support in eight nations. Cambridge University Press. https://doi.org/10.1017/ CBO9780511818431

Börzel, T., \& Risse, T. (2015). Dysfunctional institutions, social trust, and governance in areas of limited statehood. SFB-Governance Working Paper Series 67. http://doi.org/10.17169/ refubium-21967 
Bratton, M., \& Mattes, R. (2001). Support for democracy in Africa: Intrinsic or instrumental? British Journal of Political Science, 31(3), 447-474. https://doi.org/10.1017/S0007123401000175

Calderón, F. (2011). Movimientos culturales y la emergencia de una nueva politicidad. Politica e Sociedade, 10(18). https://doi.org/10.5007/2175-7984.2011v10n18p75

Canache, D., \& Allison, M. (2005). Perceptions of political corruption in Latin American democracies. Latin American Politics and Society, 47(3), 91-111. https://doi. org/10.1111/j.1548-2456.2005.tb00320.x

Carreras, M. (2016). Compulsory voting and political engagement (beyond the ballot box): A multilevel analysis. Electoral Studies, 43, 158-168. https://doi.org/10.1016/j. electstud.2016.04.005

Castells, M. (2009). Communication power. Oxford University Press. ISBN 978-0-19-956704-1

Christensen, H. S. (2016). All the same? Examining the link between three kinds of political dissatisfaction and protest. Comparative European Politics, 14(6), 781-801. https://doi. org/10.1057/cep.2014.52

Cohen, M., Lupu, N., \& Zechmeister, E. (2017). The political culture of democracy in the Americas, 2016/17: A comparative study of democracy and governance. LAPOP. www.vanderbilt.edu/ lapop/ab2016/AB2016-17_Comparative_Report_English_V2_FINAL_090117_W.pdf

Corporación Latinobarómetro. (2018). Informe 2017. Corporación Latinobarómetro.

Dadasov, R., Hefeker, C., \& Lorz, O. (2017). Natural resource extraction, corruption, and expropriation. Review of World Economics, 153(4), 809-832. https://doi.org/10.1007/ s10290-017-0288-y

Dalton, R. (2004). Democratic challenges, democratic choices: The erosion of political support in advanced industrial democracies. Oxford University Press. https://doi.org/10.1093/acprof: oso/9780199268436.001.0001

Dalton, R. (2006). Citizen politics: Public opinion and political parties in advanced industrial democracies (4th ed.). CQ Press.

Della Porta, D., \& Vannucci, A. (1999). Corrupt exchanges: Actors, resources, and mechanisms of political corruption. Routledge. https://doi.org/10.4324/9781315080284

Della Porta, D., \& Vannucci, A. (2012). The hidden order of corruption: An institutional approach. Routledge. https://doi.org/10.4324/9781315557267

Diamond, L. (1999). Developing democracy: Toward consolidation. Johns Hopkins University Press. ISBN: 9780801861567

Easton, D. (1975). A reassessment of the concept of political support. British Journal of Political Science, 5(4), 435-457. https://doi.org/10.1017/S0007123400008309

Fornos, C., Power, T., \& Garand, J. (2004). Explaining voter turnout in Latin America, 1980 to 2000. Comparative Political Studies, 37(8), 909-904. https://doi.org/10.1177 $\% 2 \mathrm{~F} 0010414004267981$

Fuchs, D. (2007). The political culture paradigm. In R. Dalton \& H. D. Klingeman (Eds.), The Oxford handbook of political behavior (pp. 161-184). Oxford University Press. https:// doi.org/10.1093/oxfordhb/9780199270125.003.0009

Haime, A. (2017). What explains voter turnout in Latin America? A test of the effect of citizens' attitudes towards the electoral process. Revista de Ciencia Política, 37(1), 69-93. https://doi.org/10.4067/s0718-090x2017000100004

Heidenheimer, A. J. (2002). Perspectives on the perception of corruption. In A. J. Heidenheimer \& M. Johnston (Eds.), Political corruption. Concepts and context (pp. 141-154). Transaction Publishers. https://doi.org/10.4324/9781315126647-14

Helmke, G., \& Levitsky, S. (2004). Informal institutions and comparative politics: A research agenda. Perspectives on Politics, 2(4), 725-740. https://doi.org/10.1017/s1537592704040472

Inglehart, R. (1988). The renaissance of political culture. American Political Science Review, 82(4), 1203-1230. https://doi.org/10.2307/1961756 
Inglehart, R., \& Welzel, C. (2005). Modernization, cultural change, and democracy: The human development sequence. Cambridge University Press. https://doi.org/10.1017/CBO9780511790881

Kaufmann, D. (1997). Corruption: The facts. Foreign Policy, 107, 114-131. https://doi. org/10.2307/1149337

Kish, L., \& Frankel, M. R. (1974). Inference from complex samples. Journal of the Royal Statistical Societ, 36(1), 1-37. https://doi.org/10.1111/j.2517-6161.1974.tb00981.x

Kitschelt, H. (2000). Linkages between citizens and politicians in democratic polities. Comparative Political Studies, 33(6-7), 845-879. https://doi.org/10.1177/001041400003300607

Knott, P. (1991). A model-based look at linear regression with survey data. The American Statistician, 45(2), 107-112. https://doi.org/10.2307/2684369

Lapalombara, J. (1994). Structural and institutional aspects of corruption. Social Research, 61(2), 325-350. www.jstor.org/stable/40971035

Linz, J., \& Stepan, A. (1996). Problems of democratic transition and consolidation: Southern Europe, South America, and Post-Communist Europe. Johns Hopkins University Press.

Manzetti, L., \& Wilson, C. J. (2007). Why do corrupt governments maintain public support? Comparative Political Studies, 40(8), 949-970. https://doi.org/10.1177/0010414005285759

Morlino, L., \& Tarchi, M. (1996). The dissatisfied society: The roots of political change in Italy. European Journal of Political Research, 30(1), 41-63. https://doi. org/10.1111/j.1475-6765.1996.tb00667.x

Mungiu-Pippidi, A. (2006). Corruption: Diagnosis and treatment. Journal of Democracy, 17(3), 86-99. https://doi.org/10.1353/jod.2006.0050

Norris, P. (1999). Introduction: The growth of critical citizens? In P. Norris (Ed.), Critical citizens: Global support for democratic government (pp. 1-27). Oxford University Press. https:// doi.org/10.1093/0198295685.003.0001

Pharr, S., Putnam, R., \& Dalton, R. (2000). A quarter-century of declining confidence. Journal of Democracy, 11(2), 5-25. https://doi.org/10.1353/jod.2000.0043

Przeworski, A. (1991). Democracy and the market: Political and economic reforms in Eastern Europe and Latin America. Cambridge University Press. https://doi.org/10.1017/cbo9781139172493

Rose-Ackerman, S. (1996a). Corruption and democracy. Proceedings of the ASIL Annual Meeting, 90, 83-90. https://doi.org/10.1017/S0272503700085827

Rose-Ackerman, S. (1996b). Democracy and "grand" corruption. International Social Science Journal, 48(149), 365-380. https://doi.org/10.1111/1468-2451.00038

Rust, K. (1985). Variance estimation for complex estimators in sample surveys. Journal of Official Statistics, 1(4), 381-397.

Seligson, M. A. (2002a). The impact of corruption on regime legitimacy: A comparative study of four Latin American countries. The Journal of Politics, 64(2), 408-433. https:// doi.org/10.1111/1468-2508.00132

Seligson, M. A. (2002b). The renaissance of political culture or the renaissance of the ecological fallacy? Comparative Politics, 34(3), 237-292. www.jstor.org/stable/4146954?origin=JSTOR-pdf

Seligson, M. A. (2006). The measurement and impact of corruption victimization: Survey evidence from Latin America. World Development, 34(2), 381-404. https://doi. org/10.1016/j.worlddev.2005.03.012

Stokes, S. (2006). Do informal rules make democracy work? In G. Helmke \& S. Levitsky (Eds.), Informal institutions and democracy: Lessons from Latin America (pp. 125-142). John Hopkins University Press.

Welzel, C., \& Inglehart, R. (2007). Mass beliefs in comparative politics. In C. Boix \& S. Stokes (Eds.), The Oxford handbook of comparative politics (pp. 297-316). Oxford University Press. https://doi.org/10.1093/oxfordhb/9780199566020.003.0013

Zechmeister, E. J., \& Lupu, N. (Eds.). (2019). Pulse of democracy. LAPOP. www.vanderbilt. edu/lapop/ab2018/2018-19_AmericasBarometer_Regional_Report_10.13.19.pdf 


\title{
8 Towards new rules for political transparency
}

\author{
Lessons from anti-corruption \\ initiatives in Peru and Chile
}

Bettina Schorr ${ }^{1}$

\section{Introduction}

The assertion that good governance by means of effective regulatory institutions will mitigate the different expressions of the resource curse is commonplace in the literature. ${ }^{2}$ In contrast to this omnipresence and with a few notable exceptions (Dietsche, 2007; Haslam, 2016; Orihuela, 2013, 2018; Orihuela et al., 2021), silence reigns as to how these institutions can be built. In fact, as the resource curse literature points out, achieving political change can be assumed to be particularly challenging in resource-rich economies. For a variety of incentives set by resource dependency, these polities tend to feature political closure (Lipsky, 1968), i.e. the existence of high barriers preventing non-hegemonic (non-elite) demands for regulation from entering the policy processes to initiate institutional change. How can countries under these adverse circumstances overcome their resistance to regulatory change and improve governance-even against the will of established gatekeepers in the executive and legislative branches?

The Andean countries are a case in point: given their focus on the extractive sector, they depend on and perform according to global price cycles. Poverty is widespread even after the latest economic boom, and they are characterized by strong and multidimensional social inequalities including important power asymmetries (Damonte et al., 2018). Both economic elites as well as politicians, two groups that tend to overlap in the region, are focused on the resource sector, and the political will to regulate it is rather weak (Bebbington, 2012; Durand, 2016; Karl, 1997). Business elites enjoy strong influence, and the policy processes are generally considered to be closed (Bogliaccini \& Luna, 2016; Crabtree \& Durand, 2017; Durand, 2016; Fairfield, 2015; Olavarría-Gambi \& Dockendorff, 2016).

Recent anti-corruption politics in Chile and Peru are examples for contentious political processes that did achieve institutional change, notwithstanding the adverse conditions described before. During the last decade, the societies of both countries learned about several enormous corruption scandals that elicited enormous social disapproval and, ultimately, drove presidents to draft and promote comprehensive reform agendas. Against substantive resistance in 
Congress and by other politicians, a series of reforms aiming at political transparency, e.g. the regulation of political finance and rules regarding electoral integrity, were adopted.

This chapter explores the recent transparency politics in Chile and Peru as processes that led to institutional change in the context of the potentially adverse conditions of resource economies. The cases were selected because they share important similarities and interesting differences. Regarding similarities, in both countries, transparency politics are not new: since before the recent waves of corruption scandals swamped the countries, specialized actors existed that have lobbied for political transparency for quite some time. However, it was not until the period inaugurated by the recent wave of scandals that activism and social disapproval actually translated into institutional change. Exploring the political processes in Chile and Peru will allow us to identify the causal mechanisms that worked towards translating social disapproval and activism into actual change.

On the other hand, the two cases reveal differences regarding the ways and the time-frame in which the recent transparency processes have unfolded: Chile went through a much quicker and less contentious process, while in Peru it took more time and brought the country repeatedly to the brink of collapse. Thus, the comparison will identify background conditions that account for a smoother or more turbulent process respectively. On a more general level, this comparison adds nuance to the exploration of opportunities for institutional change in resource economies (and other difficult environments).

The case of anti-corruption politics is particularly insightful for resource economies, which research has found to be very prone to corruption (Brollo et al., 2013; Kirsch, 2014; Vicente, 2010; Zhu \& Wu, 2014). The easy money provided by the extractive sector especially during boom times sets strong incentives for rent-seeking behavior and collusion between politics and money. Also, the opportunities to access rents can motivate state officials to prevent institutional changes that would end up limiting this access. Thus, political corruption and resistance to change do mutually reinforce each other, and this vicious cycle can only be broken by pushing the regulators to regulate themselves.

This chapter explores the political processes targeting political transparency regulation in Chile and Peru in order to achieve a better understanding of the conditions and mechanisms facilitating institutional change in political environments unreceptive to change, such as those characterized by resource dependence. Regarding the period under analysis, in both cases the exploration starts with the recent waves of mega-corruption scandals (2014 in Chile and 2016 in Peru). It finishes with the terms of the respective presidents who had promoted the reforms in their Congresses (in Chile, Michelle Bachelet in 2018, and in Peru, Martín Vizcarra in 2020). In neither case was the reform agenda adopted completely, and the political processes are still ongoing.

The chapter draws on empirical data collected during two field stays in Chile and Peru in 2018 and 2019. Interviews were conducted with public officials, with activists from civil society organizations and international organizations 


\section{Bettina Schorr}

and with experts. In addition, secondary literature including grey literature and press articles (print and electronic) were consulted.

The chapter proceeds as follows: The following section offers background information on political corruption and anti-corruption initiatives in the Andean region during the last two decades. Section 3 describes the political processes that have unfolded in Chile and Peru aiming at the adoption of new regulation for political transparency. The analysis in Section 4 highlights two factors that were key to institutional change in both cases: pressure by presidents and by organized civil society. The last section concludes with some general reflections on the conditions and factors promoting institutional change in resource economies.

\section{Political corruption and anti-corruption politics in the Andes}

While corruption is defined as the abuse of public office for private gain, which can be individual or collective (Heidenheimer \& Johnston, 2017; World Bank, 1997), grand or political corruption refers to the type of collusion occurring at a high level of the state apparatus. It involves politicians embezzling public money or bending the law for private interests. In some cases, outright state capture takes place where legislation, formally developed and properly passed by the legislature, grants benefits in a corrupt manner (Dal Bó, 2006). Thus, corrupt influence is used to have laws written for specific private benefits.

In the Andean region, political corruption constitutes a grave problem that has enormous economic costs, perpetuates poverty and social inequality and prevents the development of institutional quality (Hessami, 2014; Rose-Ackerman \& Palifka, 1999). ${ }^{3}$ It includes different expressions such as the bribing of politicians by private actors, secretive contributions to electoral campaigns or political parties, traffic of influence and the use of public resources for personal benefits or patrimonial practices (Barozet et al., 2020; Bogliaccini \& Luna, 2016; Cañete Alonso, 2018; Crabtree \& Durand, 2017; Durand, 2018; Fairfield, 2015; Matamala, 2015; Mönckeberg, 2015) on the national as well as the subnational levels (Barozet et al., 2020; Dargent \& Muñoz, 2016; Melgar, 2017; Muñoz, 2019).

In the face of the latest mega scandals, citizens' perception of corruption and especially political corruption has steadily grown in the region. ${ }^{4}$ Following the Global Barometer on Corruption in Latin America and the Caribbean 2019 (Pring \& Vrushi, 2019), 85\% of the respondents think that government corruption is a big problem, more than $50 \%$ perceive that corruption is getting worse in their country, and 65\% think their government is run by and for a few private interests. Politicians and public office holders are seen as the most corrupt groups.

The growing perception of political corruption and its costs has catapulted the subject on the top of domestic and international political agendas. On paper, all Andean countries feature some sort of anticorruption legislation (Blake \& 
Morris, 2009; Rotberg, 2019). Prosecutors and attorneys are increasingly taking up the battle against individuals allegedly involved in acts of corruption. However, existing legislation has been criticized for not raising the stakes for collusion in the political arena. In particular, rules ensuring electoral integrity and preventing vote-buying, transparency of political finance and the efficiency and transparency of public services and investments are lacking. In fact, TI reports that the majority of citizens (57\%) think that their government is not doing enough to end corruption.

\section{Towards political transparency in Chile and Peru}

Reflecting regional developments, Peru and Chile share a history of political corruption, which became especially pronounced during the respective dictatorships of Augusto Pinochet (Orellana Vargas, 2018) and Alberto Fujimori (Dammert \& Sarmiento, 2019; Schulte-Bockholt, 2013; Torrico et al., 2017). In both countries, corruption scandals continued to pop up after the transition to democracy. ${ }^{5}$ The last decade eventually saw a whole wave of corruption scandals revealed, which enormously raised public attention to the subject and laid the grounds for the initiation of political processes targeting institutional change in anti-corruption matters.

In Chile, starting in 2013 several major cases of collusion were revealed which involved public officials and their families from across the entire political spectrum (Casas-Zamora \& Carter, 2017, p. 20). The most important cases were two tax frauds involving private companies, the National Tax System and both the conservative party UDI (Unión Demócrata Independiente) (in the Penta Case) ${ }^{6}$ as well as the left-wing Nueva Mayoría (the SOQUIMICH case). ${ }^{7}$ The Caso Corpesca confirmed the large influence of the fishing industry on the sector's governing legislation. While these scandals (and many more) provoked public outrage and nurtured demands for stricter regulation, the revelation of the Caso Caval became a political tipping point. It involved then President Bachelet's son Sebastián Dávalos and his wife in an act of traffic of influence. Given a rising public attention to the case, Bachelet declared the struggle against corruption as one of her top priorities and instituted in February 2015 a technical commission, the Consejo Asesor Presidencial contra los Conflictos de Interés, el Tráfico de Influencias y la Corrupción (Presidential Advisory Council against Conflicts of Interest, Traffic of Influence and Corruption, henceforth Consejo Asesor) charged with preparing a report with policy proposals for a governance scheme that would promote political transparency and reduce political corruption. The Commission was comprised of 16 persons who came from very different political backgrounds and headed by economist Eduardo Engel, a renowned expert in the field, hence its other name Engel Commission (Arís et al., 2019; Sahd \& Valenzuela, 2018).

After only 45 days, the Consejo Asesor submitted a final report of 217 pages with 234 policy recommendations for probity and transparency in the public sector. The proposals were grouped into five categories: prevention of 
corruption, regulation of conflicts of interest, political finance, trust in markets and, finally, integrity, ethics and civil rights (Consejo Asesor, 2015). With the exception of those policies affecting subnational governments, President Bachelet accepted the majority of the recommendations and sent them to Congress for adoption. In the following three years, a frenetic reform process set in and as of 2018, the Chilean Congress had approved 62\% of the policy proposals formulated by the Engel Commission (Arís et al., 2019; Sahd \& Valenzuela, 2018).

In Peru, the various scandals related to the Odebrecht Case revealed in 2016 opened up a window of opportunity for a process of policy change addressing the relationship between politics and money. Investigations in the US confirmed that Odebrecht had bribed several high-ranking Peruvian politicians in order to obtain public contracts (Durand, 2018). Former politicians were put under arrest, amongst them virtually all ex-presidents of the country and several high-profile political leaders such as the opposition leader Keiko Fujimori. Eventually even then-President Pedro Pablo Kucinsky resigned when facing congressional impeachment because of his involvement with Odebrecht during his time as a minister of the government of Alejandro Toledo (Vergara, 2018). His vice president Martin Vizcarra followed him into office. Only a couple of months later, a new corruption scandal convulsed the judiciary (the so called NCM Audios), revealing a vast collusive network of judges, officials and members of a criminal organization. Given the high public salience of the subject of political corruption at the moment, Vizcarra seized the opportunity to advance a wider political reform. In December 2018, he convened the Comisión de Alto Nivel para la Reforma Política (High-Level Commission for Political Reform), which consisted of five political scientists from important Peruvian universities led by the renowned expert Fernando Tuesta. In March 2019, the Commission submitted a report of over 400 pages, which contained 12 reform proposals organized in four thematic blocks: anti-corruption and reporting, governability, political organizations and representation, and electoral participation and civic politics (four constitutional changes and eight legislative changes). Political transparency and accountability were a transversal subject. With the exception of the reintroduction of a bicameral system of representation, President Vizcarra accepted all reform proposals and passed them on to the Constitutional Committee of the Peruvian Congress. By 2020, the Congress had adopted the majority of the reform proposals (Muñoz \& Neyra, 2021).

\section{Promoting institutional change: pressures from the inside and from the outside}

Notwithstanding the support of individual congressmen and-women, in Chile and Peru the reform proposals concerning political transparency and accountability encountered a reluctant legislature. Members of both commissions consider the dominant motives to have been ideological reasons or the perception that the reforms would jeopardize legislators' private interests. ${ }^{8}$ Despite of 
this resistance, legislators were driven to adopt the reforms by a combination of pressure exerted from the inside and the outside of the government.

In both countries, presidents were key in promoting the reform agendas from within the government. They convened the technical commissions, accepted their proposals and pressured the legislatures to adopt them. Their motives to initiate the reform processes were different. While Vizcarra acted out of a political belief that a reform was necessary, Bachelet's decision responded more to the desire of immediate political survival. Because the Caso Caval involved her son, the opposition and the media accused her of collusion and of covering up her son's illegal activities. While initially inactive, when public disapproval of her presidency rose to an astonishing 61\%, she announced that the struggle against corruption would be one of her top priorities.

Regardless of these different motivations, both presidents would act in the following years as fierce defendants of the reform proposals. They faced different conditions: in Chile, the relation between the president and Congress was much less tense than in Peru which per se facilitated the reform process. In addition, Bachelet had two factors playing to her advantage: First, her government was based in a stable parliamentary coalition and she was able to mobilize the support of the members - or pressure them into support. To do so, she used an institutional vehicle called "urgency legislation" which forces legislators to vote on proposals classified as "urgent" within a two-week period. ${ }^{9}$ The extensive use of this instrument avoided the danger that the probity agenda would be shelved by congressional committees, or diluted in endless discussions, and thereby contributed greatly to the rapid adoption of many proposals. ${ }^{10}$

In Peru, Martin Vizcarra had a much longer and more aggressive struggle to fight with Congress over a reform agenda of a wider scope, which included constitutional reforms requiring special majorities in Congress and more complicated processes of negotiation. Vizcarra had a harder time pressuring Congress into approval because he could not rely on a stable majority in a highly fragmented and divided Congress. The dominant party was Fuerza Popular led by Keiko Fujimori, who was not only the daughter of former dictator with a similar anti-democratic posture but also fiercely engaged in a fundamental opposition to the sitting president who had beaten her at the polls (Dargent \& Muñoz, 2016). To achieve the adoption of the transparency reforms, Vizcarra had to use heavier artillery and endure several political crises. In the following two years, the Peruvian president imposed a public referendum to bolster the legitimacy of his reform proposals in 2018 (which he won) $;^{11}$ he threatened Congress with a motion of confidence and with closures in case of non-confidence in 2018 (to realize the referendum); he actually raised two questions of confidence tied to the acceptance of reform proposals in 2019, which ended with Congress granting confidence and adopting several proposals (the first motion pressured Congress into approving without violating its essence of six reforms the presidents' considered priority; the second came tied to the adoption of an amendment to the Organic Law of the Constitutional Court) $;^{12}$ he dissolved Congress after a majority denied the second motion of confidence; ${ }^{13}$ 
and he decreed new elections in 2020. While the Congress elected in 2020 adopted further reforms basically to the rhythm of social pressure, the struggle between Congress and president continued. Parliamentarians staged two attempts to remove the president from office in 2020 on the concept of moral incapacity because of unconfirmed allegations of corruption. The second one ended up succeeding and plunged the country into another violent political crisis that ended with the institution of interim president Francisco Sagasti in charge of organizing new elections in $2021 .{ }^{14}$

To promote the reform proposals, the presidents in Chile and Peru received important support from civil society in general and non-governmental organizations in particular. In both countries, the presidents and their transparency agendas counted on massive social support as expressed in the media, surveys and, in the case of Peru, mass manifestations in the streets. In Chile, a whole trend was reversed during this period. Originally, Chileans had not considered their political authorities and system to be particularly corrupt. With the media revealing one corruption scandal after the other starting in 2013, the subject of political corruption rushed onto the public agenda and at moments appeared in surveys as the most important issue for the majority of the Chilean people (Arís et al., 2019, p. 20). While approval for President Bachelet had plummeted in the aftermath of Caso Caval, it gradually increased again when her commitment to the probity agenda became clear. ${ }^{15}$

In Peru, the corruption cases revealed in the context of the Odebrecht case spurred massive public outrage of a citizenry already very sensitive to the subject of political corruption. Since 2010, Peruvians ranked corruption as one of the two most pressing problems in the country. ${ }^{16}$ Periodically, the scandals captured the main headlines of the national press, and the capital Lima repeatedly saw large social protests reclaiming an end to what was perceived as a generalized political phenomenon. Reflecting the high social support of the reform agenda, Vizcarra relied on approval rates unseen in Peruvian history, reaching a peak of 80\% in April 2020 (from 40\% the year before (IEP, 2020). In 2019, 85\% of respondents endorsed Vizcarra's decision to dissolve the Congress (ibid.)).

The two processes benefitted in particular from the support of organized action by non-governmental organizations dedicated to issues of political transparency. The most relevant of these organizations were in both countries the national chapters of Transparency International (called Proética in Peru) and international organizations (PNUD in Chile and IDEA International or Oxfam in Peru) as well as various national and local NGOs and think tanks. In Chile, the latter included the NGOs Fundación Ciudadanía Inteligente (Intelligent Citizenry Foundation, 2009), Espacio Público (Public Space, 2012) and the Observatorio del Gasto Fiscal (Observatory of Fiscal Spending). In Peru, the NGO Transparencia (Transparency) and various smaller groups actively engaged in the process.

These actors brought resources, expertise, contacts and legitimacy to the reform processes, and the reports and proposals they had already developed accelerated the work of the commissions in both Chile and Peru. In both 
countries, the technical commissions not only maintained close and friendly relations with those actors, they also shared several key personnel. ${ }^{17}$ During the drafting of the reports civil organizations acted as brokers between society and the commissions by providing channels for feeding ideas into the reform agendas, which has led scholars to speak of the co-production of public policies (Maillet et al., 2018 for the case of Chile). The fact that these organizations were generally perceived as trustworthy among ordinary Peruvians and Chileans also raised the stakes for opposition or outright veto. NGOs also provided material resources to support the work of the technical commissions, who worked ad honorem and had only limited resources to run a small secretariat and pay a coordinator. ${ }^{18}$

Finally, NGOs and civic organizations continued to monitor the reform agendas after they had been submitted to congress by combining classical lobbyism with watchdog and outreach activities. Lobbying not only helped to generate support among those legislators principally open to promoting transparency, but also allowed the NGOs to ensure a certain level of control over the process of policy formulation. In doing so, congressional maneuvers taking place behind closed doors with the aim of twisting or diluting the reform proposals could be exposed to the public.

On the other hand, outreach activities helped to mobilize public support and-more important - to sustain it in time. All of the organizations produced reports and information material that could be accessed publicly. They were also very active in their use of media, both traditional ones and new digital ones. Regarding the latter, several internet platforms were established (partly before the reform processes started), amongst them in Chile the Observatorio Anti-corruption (Anti-corruption Observatory) run in consortium by Espacio Público and Ciudadanía Inteligente and the web platform integritywatch.cl, operated by Chile Transparente, where meetings and audiences of public office holders with private actors are registered. ${ }^{19}$ In Peru, the NGO Proética runs an Observatorio de Integridad (Observatory of Integrity) and promotes veedorías ciudadanas, citizen groups, that monitor and inform on the performance of transparency initiatives in the country. In both countries, investigative journalists have set up virtual platforms that offer detailed information on politicians involved in acts of corruption. ${ }^{20}$

\section{Concluding remarks: lessons learned}

This chapter has analyzed and compared reform initiatives towards political transparency in Chile and Peru. In both countries, political or grand corruption is a large problem. The disclosure of a whole series of mega scandals marked the beginning of political processes aiming at the adoption of new regulation for political transparency. Although in neither case were the ensuing transparency agendas adopted completely, the processes did lead to institutional change against the will of reluctant congresses. In other words, legislators were indeed pushed to regulate themselves. The analysis of the processes showed that in both countries the same mechanism of change was at play involving a combination of 
pressure from the inside of governmental institutions as well as from the outside: a strategic coalition among presidents and civil society actors was able to build circumstances in which delegates could not afford to vote against the reform proposals - unless they were committed to an act of political suicide, as in fact they were in the case of Peru.

The remainder of this concluding section is dedicated to two general reflections regarding the conditions and factors promoting institutional change in resource economies where those in charge of political decisions are said to face strong incentives for impeding regulatory change.

First, an entire academic tradition embodied in social movements studies or the contentious politics literature focuses on the role of collective pressure and social mobilizations in achieving political change. The latest resource boom in Latin America, which motivated an infinite number of local conflicts over extractive projects, has inspired a great deal of scholarly interest in the topic. Studies have focused on internal dynamics of protest groups and to a minor extend explored the institutional legacies of these groups (among many Bebbington, 2012; Dietz \& Engels, 2017). In the case of transparency politics in Chile and Peru, social discontent as expressed in mass mobilizations and protest, although present, were not the driving force to introduce change. In both countries, prior scandals had elicited social mobilizations and outrage, without triggering reforms. ${ }^{21}$ Instead, the cases highlight the role of highly specialized civil society organizations acting as brokers between the executive, the legislative and society.

Together with the press and the technical commissions, these groups contributed to keeping the subject of political transparency on the public and political agendas by means of lobbyism and pressure. By using digital instruments allowing for mass communication (connective action in terms of Bennett \& Segerberg, 2012), they were able to expose voting behavior of legislatures on a permanent basis to the voters and lobby support for the agendas. Moreover, they contributed to the campaigns with expertise, infrastructure and other material resources. While the cases also stress the role of presidents as promoters of change, without the important support from civil society actors (and international organizations) the reforms would probably not have materialized. Chile is a case in point: during her first government (2006-2010), President Bachelet promoted a very similar probity agenda. Back then, specialized social actors would not work towards maintaining the president on track and providing a constant pressure on legislators. As a consequence, the reform agenda "died in Congress" (Arellano \& Carvajal, 2015). In a general perspective, thus, the cases might recommend reformers (presidents, legislators or other politicians) to form strategic coalitions with these actors so together they can attack once windows of opportunities open up.

The second reflection revolves around the greater difficulties of the Peruvian president to impose the reforms. While institutional change was ultimately accomplished in both cases, Vizcarra's struggle with Congress turned into epic battles and repeatedly drove the country to the brink of collapse. The 
differences in form and intensity directs attention to the underlying institutional fundament, i.e. the quality of democratic institutions and, consequently, the quality of decision makers. What is outstanding in the case of Chile is that after all the Chilean legislators played by the rules and responded to pressures for change, albeit unwillingly. Fair enough, since the Chilean reform agenda did not include constitutional reforms as the Peruvian did, the stake for adoption of the proposals were lower in Chile. Furthermore, the urgency legislation provided the Chilean president with a powerful institutional vehicle to impose the reforms.

These differences between the two countries are the reflection of long-term institutional developments since their independence in the 19th century (see Kurtz, 2013 for a detailed analysis). Based in an elite pact, the Chilean state evolved to a wide scope in terms of territorial control and a high capacity regarding public service delivery (Collier \& Sater, 2012; Soifer, 2015). The high standards of public bureaucracy and bureaucrats in Chile are generally acknowledged (Orihuela, 2013; Polga-Hecimovich, 2019; Silva, 2009, 2016).

Most importantly for processes of institutional change, since the end of the dictatorship of Pinochet in 1989, democracy is the only game in town. Chile possesses one of the most institutionalized and stable party systems in Latin America (Mainwaring \& Scully, 1995). Although it has been criticized for sacrificing representation for stability (Luna \& Altman, 2011; Siavelis, 2016), it has contributed to the efficient functioning of governing institutions. Since the return to democracy, party politics have been organized in two large alliances positioned on the left-right continuum. Driven by the need to avoid authoritarian setbacks, both conservative and progressive actors have learned to cooperate, and cross-party agreements became iterative supported by a set of informal institutions (Siavelis, 2006, 2016). Presidents can rely on their majority coalitions and coalitions on their partners. As a consequence, reforms have been introduced as products of negotiations on a frequent basis (Sanchez, 2011). Although Chile is not alien to practices of clientelism and patrimonialism and outright corruption (as the cases show, see also Barozet et al., 2020), at the end of the day Chilean office holders display a high commitment to democratic institutions and the basic tenets of representative democracy. As the analysis has shown, confronted not only with internal but also with external pressure they voted for the transparency reforms, although reluctantly.

In Peru, the institutional fundament and quality is of a whole different nature. The infrastructural power of the Peruvian state in terms of scope and public capacity is historically low (Kurtz, 2013). Although it has increased in recent decades, so has the power of its social opponents (Dargent et al., 2017). The bureaucratic apparatus is generally described as deficient (Polga-Hecimovich, 2019). Most importantly, the country's scores for democratic quality are notoriously low (Bertelsmann Stiftung, 2020). Democratic institutions do perform their functions, but are often inefficient due to frictions among different state agencies, a lack of professionalization of office holders and, of course, corruption. In particular, scholars point out to the party system as plainly ineffective, unable to aggregate and communicate 
political ideas and to hold delegates accountable according to programmatic lines. The existing parties are barely rooted in society, which has motivated several scholars to speak of Peru as a "democracy without parties" (Crabtree, 2010; Levitsky, 2013; Levitsky \& Cameron, 2003; Tanaka, 2005).

Parties tend to perform as electoral vehicles for individuals engaging in a political career in order to access public resources and power. They form their electoral bases by means of clientelist and patrimonialist practices (Muñoz, 2019). The detachment of parties from ideas and constituencies has dramatic consequences for the type of representatives entering congress. The commitment to democratic institutions and the responsiveness of many delegates to public demands and needs is low and depends almost exclusively on individual ethical standards. This type of delegate is not so easily pressurable into adopting an unwanted regulation-as Vizcarra's grim struggle has made clear.

Moreover, the Peruvian party system features a high number of small parties that generally do not survive more than one election period. This multiplicity translates into fragmented legislatures and severely hinders the formation of stable coalitions. Decision-making, particularly in the case of proposals affecting power relations, is difficult under these conditions, even when social demand is high and presidents raise pressure from the executive. The Peruvian agenda for transparency targeted many of the problems associated with the dysfunctionality of the party system and the low quality of democracy only to be torpedoed by expressions of precisely these problems. This vicious cycle could only be broken by a fierce battle delivered by a coalition between the president and civil society, at the costs of years of political crisis and instability.

The good news of the cases of transparency politics in Chile and Peru is that regulatory change is possible despite the expectations of the resource curse, even in the presence of adverse incentives. However, when assessing the opportunities of institutional change in resource economies, the cases stress the importance not only of a good regulation in place or efficient bureaucracies able to implement rules (Orihuela et al., 2021). The analysis also points out to the importance of the quality of the institutional fundament in place. In other words, resource economies can only be governed in a good way, when the very political fundament of the polity in question - the grounds on which those institutions that matter have to be negotiated-is of a good quality. This institutional fundament constitutes an important antecedent condition that shapes the opportunities for and forms of institutional change.

A final note of caution is called for here. As an ample political science literature reminds, the adoption of new rules does not automatically translate into them exerting the desired effect (Mazmanian \& Sabatier, 1983; Pressman \& Wildavsky, 1984). Rules need to be enforced. While transparency politics in Chile and Peru have achieved an impressive formal change in recent years, there is a rocky road ahead regarding their implementation. Both reformers as well as scholars should be attentive to the future course of events in order to develop a deeper understanding of how institutional change in the field of political transparency can have a lasting impact on politicians' behavior. 


\section{Notes}

1 I greatly appreciate the helpful comments of my colleagues Maritza Paredes, Markus Rauchecker and, especially, Hans-Jürgen Puhle.

2 Amongst many others: Boschini et al. (2007); Karl (1997); Kolstad and Wiig (2009); Lederman and Maloney (2009); Mehlum et al. (2006); Robinson et al. (2006); Ross (1999, 2015); Sarmidi et al. (2014); Tornell and Lane (1999).

3 For Peru, Quiroz calculated that between 1820 and 2000 collusion captured up to $40 \%$ of government spending and 3-4\% of GDP growth per year (Quiroz, 2008).

4 See Transparency International (2019); also other regular Latin American opinion polls, like LAPOP (Latin American Public Opinion Project) and Latinobarómetro, confirm this trend. See also Moreno in this volume.

5 In Chile the public copper company Codelco and the Ministry of Public Work and Transport in the Caso Coimas and MOP-gate were involved in corruption scandals (Silva, 2016). In Peru, the public oil company PetroPeru was charged with collusion in 2008, and a major case of embezzlement in the context of an earthquake disaster relief program was revealed, amongst many others.

6 Employees of the Penta Holding Group and officials of the National Tax System together committed tax fraud by creating fake invoices. The payments for these invoices were directed to the political campaigns of party members of UDI.

7 The company SOQUIMICH had issued false bills and receipts to get tax reductions and used fake invoices to transfer money to the party.

8 Interviews with Commission members in Lima, April 2019 and in Santiago 2018.

9 On Chilean presidents' prerogatives for urgency legislation, see Vial et al. (2011).

10 In fact, the speed of the reforms substantially reduced once urgency legislation was cancelled (Interview with Commission member, Santiago de Chile, April 2018).

11 Vizcarra proposed four reforms regarding the re-introduction of bi-camerality, the reorganization of the justice system, the prohibition for immediate reelection of parliamentarians and a new regulation of the financing of political organizations. The referendum endorsed all of the proposals with the exception of the re-introduction of bi-camerality. With this political tailwind from the citizenry, Vizcarra constituted the technical commission in charge of drafting a wider reform agenda.

12 The legislators not only refused to approve the reform of the judiciary, but they also proceeded to nominate new members of the constitutional court which not only openly contradicted the reform, but also envisioned the appointment of individuals with an alleged past of corruption.

13 Since it was the second no-confidence resolution submitted during the same presidential term (the first one took place in 2017 against Kuczinsky), the president was constitutionally endowed to dissolve Congress-which he did on September 30, 2019.

14 The crisis included a five-day interim presidency of right-wing Congressman Manuel Merino who had to resign due to social pressure.

15 See www.t13.cl/noticia/politica/bachelet-alcanza-2017-su-mejor-cierre-ano-aprobacion.

16 See Proética, Encuestas Nacionales sobre Percepciones de la Corrupción en el Peru, www. proetica.org.pe/contenido/encuesta-nacional-sobre-percepciones-de-la-corrupcion-enel-peru/

17 Eduardo Engel was the director of Espacio Público, and Marcela Rios is an officer from UNDP Chile. In Peru, Martin Tanaka and Paula Muñoz were board members of the NGO Transparencia.

18 In Chile, UNDP and Espacio Público provided funds for material and staff. In Peru, the work of the commission was supported by the German Konrad Adenauer Foundation.

19 See: http://integritywatch.cl/. Chile Transparente also opened a Centre for Legal Assistance in cases of corruption (Centro de Asesoría Legal Anti-Corrupción), which provides free legal assistance for victims of corruption or collusion, whistle-blowers, and witnesses of corruption involving public authorities, officials or institutions; see: https://denunciacorrupcion.cl/ 


\section{Bettina Schorr}

20 For instance, in Peru the website memoriayciudadania.org and the internet journal convoca. pe. In Chile, CIPER Chile (www.ciperchile.cl/) offers information and analysis.

21 On the other hand, there were also transparency reforms without social pressure, for instance under the presidency of Eduardo Frei (Olavarría-Gambi, 2016).

\section{References}

Arellano, A., \& Carvajal, V. (2015, June 8). Así murió en el congreso la agenda de probidad del primer gobierno de Bachelet. CIPER Chile. www.ciperchile.cl/2015/06/08/ asi-murio-en-el-congreso-la-agenda-de-probidad-del-primer-gobierno-de-bachelet/

Arís, M., Engel, E., \& Jaraquemada, M. (2019). Reformas anticorrupción en Chile (2015-2017): Cómo se hizo para mejorarla democracia. Konrad Adenauer Stiftung; Espacio Público.

Barozet, E., Espinoza, V., \& Ulloa, V. (2020). Élite parlamentaria e instituciones informales en Chile. Nepotismo y clientelismo como formas de sustento del poder. Revista Española De Sociología, 29(3), 595-611. https://doi.org/10.22325/fes/res.2020.37

Bebbington, A. (2012). Social conflict, economic development and extractive industries. Evidence from South America. Routledge.

Bennett, W. L., \& Segerberg, A. (2012). The logic of connective action. Information, Communication \& Society, 15(5), 739-768. https://doi.org/10.1080/1369118X.2012.670661

Bertelsmann Stiftung. (2020). BTI 2020 country report-Peru. Bertelsmann Stiftung.

Blake, C. H., \& Morris, S. D. (2009). Corruption and democracy in Latin America. University of Pittsburgh Press. https://doi.org/10.2307/j.ctt9qh6n2

Bogliaccini, J. A., \& Luna, J. P. (2016). Deflecting my burden, hindering redistribution: How elites influence tax legislation in Latin America. WIDER Working Paper 2016/92. UNUWIDER. https://doi.org/10.35188/UNU-WIDER/2016/135-2

Boschini, A. D., Pettersson, J., \& Roine, J. (2007). Resource curse or not: A question of appropriability. Scandinavian Journal of Economics, 109(3), 593-617. https://doi. org/10.1111/j.1467-9442.2007.00509.x

Brollo, F., Nannicini, T., Perotti, R., \& Tabellini, G. (2013). The political resource curse. American Economic Review, 103(5), 1759-1796. https://doi.org/10.1257/aer.103.5.1759

Cañete Alonso, R. (2018). Democracias capturadas: El gobierno de unos pocos. Oxfam International. https://doi.org/10.21201/2018.3521

Casas-Zamora, K., \& Carter, M. (2017). Beyond the scandals: The changing context of corruption in Latin America. Interamerican-Dialogue.

Collier, S., \& Sater, W. F. (2012). A history of Chile, 1808-2002 (2nd ed.). Cambridge University Press. https://doi.org/10.1017/CBO9780511991189

Consejo Asesor Presidencial contra los Conflictos de Interés, el Tráfico de Influencias y la Corrupción. (2015, April 24). Informe final. https://consejoanticorrupcion.cl/informe/

Crabtree, J. (2010). Democracy without parties? Some lessons from Peru. Journal of Latin American Studies, 42(2), 357-382. https://doi.org/10.1017/S0022216X10000477

Crabtree, J., \& Durand, F. (2017). Peru: Elite power and political capture. Zed Books. https:// doi.org/10.5040/9781350221758

Dal Bó, E. (2006). Regulatory capture: A review. Oxford Review of Economic Policy, 22(2), 203-225. https://doi.org/10.1093/oxrep/grj013

Dammert, J. L., \& Sarmiento, K. (2019). Corruption, organized crime, and regional governments in Peru. In R. I. Rotberg (Ed.), Corruption in Latin America: How corporations and politicians steal from citizens (pp. 179-204). Springer International Publishing. https://doi. org/10.1007/978-3-319-94057-1_8

Damonte, G., Schorr, B., \& Velásquez Castellanos, I. O. (2018). Introduction. In G. Damonte, B. Schorr, \& I. O. Velásquez Castellanos (Eds.), Growth, inequality and the 
challenges for sustainability in a post-boom scenario in the Andean region (pp. 17-32). Konrad Adenauer Stiftung e.V. http://doi.org/10.17169/refubium-1427

Dargent, E., Feldmann, A. E., \& Luna, J. P. (2017). Greater state capacity, lesser stateness: Lessons from the Peruvian commodity boom. Politics \& Society, 45(1), 3-34. https://doi. org $/ 10.1177 / 0032329216683164$

Dargent, E., \& Muñoz, P. (2016). Peru: A close win for continuity. Journal of Democracy, 27(4), 145-158. https://doi.org/10.1353/jod.2016.0070

Dietsche, E. (2007). Why the quality of institutions is not a cure for the 'resource curse'. The Journal of Energy and Development, 32(2), 262-282. www.jstor.org/stable/24813112

Dietz, K., \& Engels, B. (2017). Contested extractivism, society and the state: An introduction. In K. Dietz \& B. Engels (Eds.), Contested extractivism, society and the state: Struggles over mining and land (pp. 1-19). Palgrave Macmillan UK. https://doi.org/10.1057/978-1-137-58811-1

Durand, F. (2016). Cuando el poder extractivo captura el Estado: Lobbies, puertas giratorias y paquetazo ambiental en Perú. Oxfam.

Durand, F. (2018). Odebrecht: La empresa que capturaba gobiernos. Oxfam and Pontificia Universidad Católica del Perú Fondo Editorial.

Fairfield, T. (2015). Private wealth and public revenue: Business power and tax politics in Latin America. Cambridge University Press. https://doi.org/10.1017/CBO9781316104767

Haslam, P. A. (2016). Overcoming the resource curse: Reform and the rentier state in Chile and Argentina, 1973-2000. Development and Change, 47(5), 1146-1170. https://doi. org/10.1111/dech.12259

Heidenheimer, A. J., \& Johnston, M. (Eds.). (2017). Political corruption: Concepts \& contexts. Routledge. https://doi.org/10.4324/9781315126647

Hessami, Z. (2014). Political corruption, public procurement, and budget composition: Theory and evidence from OECD countries. European Journal of Political Economy, 34, 372-389. https://doi.org/10.1016/j.ejpoleco.2014.02.005

Instituto de Estudios Peruanos-IEP. (2020). IEP Informe de opinión-abril 2020: Encuesta telefónica a nivel nacional (Informe de Opinión). Instituto de Estudios Peruanos. https://iep. org.pe/wp-content/uploads/2020/04/Informe-OP-Abril-2020-5-Domingo-26-2.pdf

Karl, T. (1997). The paradox of plenty: Oil booms and petro-states. University of California Press. http://hdl.handle.net/2027/heb.31620.0001.001

Kirsch, S. (2014). Mining capitalism: The relationship between corporations and their critics. University of California Press.

Kolstad, I., \& Wiig, A. (2009). It's the rents, stupid! The political economy of the resource curse. Energy Policy, 37(12), 5317-5325. https://doi.org/10.1016/j.enpol.2009.07.055

Kurtz, M. J. (2013). Latin American state-building in comparative perspective: Social foundations of institutional order. Cambridge University Press. https://doi.org/10.1017/CBO9781139019668

Lederman, D., \& Maloney, W. F. (2009). In search of the missing resource curse. Economía, 9(1), 1-56. https://doi.org/10.1353/eco.0.0012

Levitsky, S. (2013). Peru: Challenges of a democracy without parties. In J. I. Domínguez \& M. Shifter (Eds.), Constructing democratic governance in Latin America (4th ed., pp. 282-315). The Johns Hopkins University Press.

Levitsky, S., \& Cameron, M. A. (2003). Democracy without parties? Political parties and regime change in Fujimori's Peru. Latin American Politics and Society, 45(3), 1-33. https:// doi.org/10.1111/j.1548-2456.2003.tb00248.x

Lipsky, M. (1968). Protest as a political resource. American Political Science Review, 62(4), 1144-1158. https://doi.org/10.2307/1953909

Luna, J. P., \& Altman, D. (2011). Uprooted but stable: Chilean parties and the concept of party system institutionalization. Latin American Politics and Society, 53(2), 1-28. https:// doi.org/10.1111/j.1548-2456.2011.00115.x 
Maillet, A., Faure, A., \& Carrasco, S. (2018). Organizaciones 'ciudadanas' y coproducción de las políticas públicas: Ciudadano inteligente, espacio público y la agenda de probidad en Chile (2015-2016). In C. Launay-Gama \& O. Dabène (Eds.), Los efectos de los procesos participativos en la acción pública (pp. 17-50). Teseo.

Mainwaring, S., \& Scully, T. R. (Eds.). (1995). Building democratic institutions: Party systems in Latin America. Stanford University Press. www.loc.gov/catdir/description/cam026/93046528.html

Matamala, D. (2015). Poderoso caballero: El peso del dinero en la política chilena. Editorial Catalonia.

Mazmanian, D. A., \& Sabatier, P. A. (1983). Implementation and public policy. Scott, Foresman and Co.

Mehlum, H., Moene, K., \& Torvik, R. (2006). Institutions and the resource curse. The Economic Journal, 116(508), 1-20. https://doi.org/10.1111/j.1468-0297.2006.01045.x

Melgar, S. (2017). La red de la bestia: La construcción de redes de corrupción en los gobiernos subnacionales, el caso de César Álvarez en Áncash. Revista De Ciencia Política Y Gobierno, 4(8), 139-165. https://doi.org/10.18800/rcpg.201702.006

Mönckeberg, M. O. (2015). El saqueo de los grupos económicos al Estado chileno. Debolsillo.

Muñoz, P. (2019). Buying audiences: Clientelism and electoral campaigns when parties are weak. Cambridge University Press. https://doi.org/10.1017/9781108525015

Muñoz, P., \& Neyra, A. (2021). Retos para una reforma de la institucionalidad política peruana. In A. Beltrán, C. Sanborn, \& G. Yamada (Eds.), En búsqueda de un desarrollo integral. Fondo Editorial de la Universidad del Pacífico.

Olavarría-Gambi, M. (2016). Agenda and public policy: Evidence from Chile. International Journal of Public Administration, 39(2), 157-172. https://doi.org/10.1080/01900692.2014.1003383

Olavarría-Gambi, M., \& Dockendorff, A. (2016). Implementing meritocracy in senior public administration: The dilemma for Chilean politicians. Public Organization Review, 16(4), 561-582. https://doi.org/10.1007/s11115-016-0360-4

Orellana Vargas, P. (2018). Probidad y corrupción en Chile. El punto de quiebre: Un caso de ética Latinoamericana. Editorial Académica Española.

Orihuela, J. C. (2013). How do 'mineral-States' learn? Path-dependence, networks, and policy change in the development of economic institutions. World Development, 43, 138-148. https://doi.org/10.1016/j.worlddev.2012.10.004

Orihuela, J. C. (2018). Institutions and place: Bringing context back into the study of the resource curse. Journal of Institutional Economics, 14(1), 157-180. https://doi.org/10.1017/ S1744137417000236

Orihuela, J. C., Mendieta, A., Pérez, C., \& Ramírez, T. (2021). From paper institutions to bureaucratic autonomy: Institutional change as a resource curse remedy. World Development, 143, 105463. https://doi.org/10.1016/j.worlddev.2021.105463

Polga-Hecimovich, J. (2019). Bureaucracy in Latin America. In G. Prevost (Ed.), Oxford research encyclopedia of politics. Oxford University Press. https://doi.org/10.1093/ acrefore/9780190228637.013.1675

Pressman, J. L., \& Wildavsky, A. B. (1984). Implementation: How great expectations in Washington are dashed in Oakland; Or, why it's amazing that federal programs work at all, this being a saga of the economic development administration as told by two sympathetic observers who seek to build morals on a foundation (3rd ed.). University of California Press.

Pring, C., \& Vrushi, J. (2019). Global Corruption Barometer, Latin America \& the Caribbean 2019-Citizens' views and experiences of corruption. Transparency International.

Quiroz, A. W. (2008). Corrupt circles: A history of unbound graft in Peru. Woodrow Wilson Center Press and Johns Hopkins University Press.

Robinson, J. A., Torvik, R., \& Verdier, T. (2006). Political foundations of the resource curse. Journal of Development Economics, 79(2), 447-468. https://doi.org/10.1016/j. jdeveco.2006.01.008 
Rose-Ackerman, S., \& Palifka, B. J. (1999). Corruption and government: Causes, consequences, and reform. Cambridge University Press. https://doi.org/10.1017/CBO9781139175098

Ross, M. L. (1999). The political economy of the resource curse. World Policy, 51(2), 297-322. https://doi.org/10.1017/S0043887100008200

Ross, M. L. (2015). What have we learned about the resource curse? Annual Review of Political Science, 18(1), 239-259. https://doi.org/10.1146/annurev-polisci-052213-040359

Rotberg, R. I. (2019). The corruption of Latin America. In R. I. Rotberg (Ed.), Corruption in Latin America: How corporations and politicians steal from citizens (pp. 1-25). Springer International Publishing. https://doi.org/10.1007/978-3-319-94057-1_1

Sahd, J., \& Valenzuela, C. (2018). La economía política de la agenda de probidad y transparencia de Chile. Banco Interamericano de Desarrollo.

Sanchez, O. (2011). Mobilizing resources in Latin America: The political economy of tax reform in Chile and Argentina. Palgrave Macmillan US. https://doi.org/10.1057/9780230119659

Sarmidi, T., Hook Law, S., \& Jafari, Y. (2014). Resource curse: New evidence on the role of institutions. International Economic Journal, 28(1), 191-206. https://doi.org/10.1080/1 0168737.2013.787110

Schulte-Bockholt, A. (2013). Corruption as power: Criminal governance in Peru during the Fujimori era (1990-2000). Peter Lang Publishers. https://doi.org/10.3726/978-3-0351-0496-7

Siavelis, P. M. (2006). Accommodating informal institutions and Chilean democracy. In G. Helmke \& S. Levitsky (Eds.), Informal institutions and democracy: Lessons from Latin America (pp. 33-55). Johns Hopkins University Press.

Siavelis, P. M. (2016). Crisis of representation in Chile? The institutional connection. Journal of Politics in Latin America, 8(3), 61-93. https://journals.sub.uni-hamburg.de/giga/jpla/ article/viewFile/1004/1004-1042-1-PB.pdf

Silva, P. (2009). In the name of reason: Technocrats and politics in Chile. Pennsylvania State University Press. www.jstor.org/stable/10.5325/j.ctt7v1c5

Silva, P. (2016). 'A poor but honest country': Corruption and probity in Chile. Journal of Developing Societies, 32(2), 178-203. https://doi.org/10.1177\%2F0169796X15609712

Soifer, H. D. (2015). State building in Latin America. Cambridge University Press. https://doi. org/10.1017/CBO9781316257289

Tanaka, M. (2005). Democracia sin partidos Perú, 2000-2005: Los problemas de representación y las propuestas de reforma política. Colección Mínima.

Tornell, A., \& Lane, P. R. (1999). The voracity effect. American Economic Review, 89(1), 22-46. https://doi.org/10.1257/aer.89.1.22

Torrico, G., Libón, Ó., \& Martorellet, C. (2017, October 19). Más de 500 personajes investigados por casos de corrupción. https://memoriasdelacorrupcion.convoca.pe/reportajes/Masde-500-personajes-investigados-por-casos-de-corrupcion.html

Vergara, A. (2018). Latin America's shifting politics: Virtue, fortune, and failure in Peru. Journal of Democracy, 29(4), 65-76. https://doi.org/10.1353/jod.2018.0063

Vial, J., Aninat, C., Landregan, J., \& Navia, P. (2011). Political institutions, policymaking processes and policy outcomes in Chile. IDB Working Paper No. 216. Inter-American Development Bank. https://doi.org/10.2139/ssrn.1815897

Vicente, P. (2010). Does oil corrupt? Evidence from a natural experiment in West Africa. Journal of Development Economics, 92(1), 28-38. https://econpapers.repec.org/article/ eeedeveco/v_3a92_3ay_3a2010_3ai_3a1_3ap_3a28-38.htm

World Bank. (1997). The World Bank annual report. World Bank Group. http://documents.worldbank.org/curated/en/652071468153843688/The-World-Bank-annual-report-1997

Zhu, J., \& Wu, Y. (2014). Who pays more "tributes" to the government? Sectoral corruption of China's private enterprises. Crime, Law and Social Change, 61(3), 309-333. https://doi. org/10.1007/s10611-013-9504-4 


\title{
9 Between environmental subsystem change and extractive regime resilience
}

\author{
Beyond the apparent development of \\ Chilean environmental institutions \\ (1990-2019)
}

Antoine Maillet ${ }^{1}$ and Sebastián Carrasco

\section{Introduction}

Chile is not a typical case of resource curse. Since the Pinochet dictatorship ended, it has been praised for the quality of its institutions, particularly by investors (World Bank Group, 2019). Some even argue that it managed to overcome the curse (Haslam, 2016). However, these optimistic views have been confronted by critics of the growth-oriented model, who have increasingly mobilized against extractive projects since the end of the 1990s (Delamaza et al., 2017). The opposition towards particular projects had cumulative effects that led to larger critique of the environmental policy and can be linked to policy change at the end of the 2010s (Sepúlveda \& Villarroel, 2012). At the same time, this emerging environmental critical discourse and its consequences for policy implementation were met by growing discontent by the private sector, which began to see it as an obstacle to its own interests that they framed as national interests.

The commodity boom took place in this setting where neither the private sector nor environmentalists had a positive appraisal of Chilean environmental institutions that have deemed variously as market-conforming (Tecklin et al., 2011) or anti-private sector (Lira, 2017). This debate also frames our approach to the questions of this book. To answer the question of whether institutions that were developed and implemented did foster a greater distribution of the extractive sector's gains and a stronger reduction of the extractive sector's costs, we have to establish whether environmental institutions have obstructed or hindered extractive projects. To do so, we need a theoretical framework that will allow us to tackle institution-building and institutional change, going beyond formal modifications that might mask the continuity of inadequacies. In short, our main argument is that the different transformations of environmental institutions in Chile turn out to be rather marginal modifications that, despite advancing in certain aspects, do not change the policy regime. 
The structure of this chapter is as follows. In the first place, we elaborate a theoretical framework based in the literature about policy change, especially in environmental politics. Then, we propose a narrative of the institutional path of environmental institutions in Chile and the determinants of their change, arguing that these transformations are only apparent. Later, we confront the narrative of an institutional path with the data on expenditure in environmental protection and investment in mining projects. This section shows that Chilean institutions have neither slowed down nor accelerated the dynamics of the commodity boom, and that the dynamic of change in the environmental subsystem is nested in a largely unchanged extractive regime. Finally, some conclusions are provided that contribute to a better understanding of the dynamics of environmental policies in Chile.

This chapter is based on a large literature review about Chilean environmental policy since the 1990s, several case studies about specific laws or conflicts, and interviews with policymakers, private sector officials, environmentalists and academic experts. For the case studies, newspapers and other media (particularly from Diario Financiero) and the story of law (historia de la ley) that the Chilean Congress publishes were valuable sources. Other government documents were also analyzed, such as reports that evaluate and analyze the implementation of environmental assessment instruments. Finally, we also used a database delivered by the Environmental Assessment Service (SEA), to analyze the evolution of mining projects in the country.

\section{Path dependence, tensions and apparent policy change in environmental policy}

The hallmark of historical institutionalism is the concept of path dependence (Mahoney, 2000). Its construction has been a major breakthrough in neo-institutionalist studies, as it has allowed to envision institutional processes as deeply structured by the past and perpetuated by the increasing returns the institutions produce (Pierson, 2004). However, it would be misleading to take it as negation of a possibility of change, as a concomitant literature on policy change has made clear. Instead, the observation of path dependence has motivated further developments in conceptualizing forms of change, building on incrementalism to create alternative categories to replacement such as layering, conversion or drift (Mahoney \& Thelen, 2010; Streeck \& Thelen, 2005). Other authors have observed "hybridization" (Maillet \& Rozas Bugueño, 2019).

Layering in particular has been fruitfully used for environmental policy analysis in the case of Peru, where a process described as fragmented layering has happened (Orihuela \& Paredes, 2017). Change came the form of new layers growing on formal environmental institutions that remained fragmented among various public organizations.

More important than what this process tells us about Peru's environmental trajectory is the general finding that formal and procedural changes such as institution-building do not necessarily mean that there is a substantial policy 
change. Since apparent change is relatively frequent, the literature has distinguished between adaptive and transformative change, based in the observation of neoliberal resilience (Madariaga, 2016). Opponents of change who face external pressure may embrace or even propose (apparent) changes in order to preserve their dominant position.

Understanding the concepts of policy subsystem and policy regime helps understand this difference. Our hypothesis is that apparent change is the outcome of a process of change in the subsystem level, and resilience in the regime. By switching from a subsystem to a regime perspective, we are better equipped to analyze the power issues at stake. Regime has been proposed in policy and governance analysis as a way to study the governing arrangements that tackle issues that span beyond subsystem boundaries (Jochim \& May, 2010) or "dispersed problems that lack comprehensive efforts to address them" (May \& Jochim, 2013). A regime is characterized by a set of ideas, governing arrangements and interests of stakeholders (ibid.). Regime analysis tends to address the level of problems, ideas, institutions and actors, while subsystem analysis tends to focus instead on the formal institutions.

While regimes and subsystems often are analyzed at the national level, multilevel analysis is particularly suited for environmental issues. They are sometimes even framed strictly as global issues, with a focus on "world-level organizations, understandings, and assumptions that specify the relationship of human society to nature" (Meyer et al., 1997). They can also be looked at from a local point of view where the focus is put on restricted areas, where environmental damages and suffering are localized (Delamaza et al., 2017). However, instead of exclusionary positions, the literature has mainly adopted an interconnected perspective, manifest in the expression of glocalization, that can be applied for example to issues such as mining conflicts (Paredes, 2016).

Processes related to environmental public policies in particular cannot be reduced to either an isolated top-down or bottom-up succession of events, but have to be considered in their transnational aspects (Orihuela, 2014). Nevertheless, the national level remains prominent because that is where environmental rules, standards or organizations can be observed when they are built. In that case, the typical entry from a policy study perspective builds on a subsystem approach to public policy: "Policy subsystems are semi-autonomous subsets of a political system with particularized policies, processes, and politics tailored to their issues" (Heikkila et al., 2018). The creation of new organizations to deal with emerging issues, such as agencies or ministries, usually takes place within a tension between on the one side the urge for looking at the intersectoral or trans-sectoral ${ }^{2}$ dimensions of a problem, and on the other the specific logic of sectorization, which operates in such a way that a problem might not be taken seriously until it has its own subsystem (Muller, 2009).

This problem of the sectoral or intersectoral character of policies has been studied for topics such as gender or ethnic discrimination (Halpern \& Jacquot, 2015; Muller, 2009), but this dilemma is also applicable for 
environmental policies. New organizations have been created around the world, often in charge of intersectoral coordination, but with little power to do so. In fact, they have dealt with a sectorization trap: confining the environmental problem in a subsystem where the transversal dimension is lost, or at least passes into the background. This whole process can also be read in terms of power. As Pierson showed, power gets built in institutions (Pierson, 2015). Having a ministry - the formal component of a subsystem-does not resolve the power issues. On the contrary, it might well hide it, for some time at least, below the symbolic gain produced by the formal creation of a new institution such as the environmental ministry. So, there might be change, but it might be only apparent.

To go beyond apparent change and grasp these power issues, we need a concept able to consider the environmental issues as a transversal problem. To do so, the analytical answer lies in the concept of policy regime, an excellent alternative to tackle "boundary-spanning problems" (Jochim \& May, 2010). In short, the main argument of this literature is that even apparently large institutional changes are not necessarily transformative. In the case of environmental policies, this implies that even when there have been changes in formal institutions, in general these are actually only changes in the subsystem, because the regime (as understood by May \& Jochim, 2013) continues to operate with the same set of ideas and interests of actors. More generally, this case adds to the findings regarding the continuity and resilience that neoliberalism has had in Chile after the dictatorship (Madariaga, 2018).

In the case at hand, going back to the problem-based regime analysis has important pay-offs, as it allows us to recast the discussion of the emergence of the limitations of the environmental institutions into a discussion on the resilience of the extractive regime. ${ }^{3}$ In both cases, we deal with the literature on policy change. We should at the same time look at why and how countries follow global trends in how their environmental subsystem plays out, but also how this affects—or not - the more relevant game of the developmental regime; in the case of Chile, an extractive one.

\section{Apparent change: the trajectory and determinants of Chilean ecological modernization}

During the Pinochet dictatorship, the environment received scarce attention (Silva, 1996). With the return to democracy came a big push for environmental protection, which generated two waves of ecological modernization (CamposMedina, 2019). The first one led to the Law 19300 of the environment, which created the National Corporation of Environment (CONAMA) and the Environmental Impact Evaluation System (SEIA) in 1994, and the second to the creation of the Environment Ministry, the Superintendence of Environmental and environmental courts through several laws between 2010 and 2012. The design and implementation of these formal institutions are the product of the tension between processes at the subsystem and regime levels. 


\section{Foundation of the environmental system: the creation of CONAMA and the system of environmental impact}

In 1992, President Patricio Aylwin sent a bill to create a new formal environmental institution that was approved in 1994, a few days before he left office. The newly created CONAMA — which ranked lower than ministries-was charged with the task of defining environmental policy (Carruthers, 2001) and advocating for environmental issues in sectoral ministries (Barandiaran, 2016). The SEIA began to operate only three years later, after the implementing regulations (reglamento) of the law finally passed.

Contradictory pressures are apparent in the design of this environmental system. The policy subsystem around CONAMA and SEIA was placed at a disadvantage compared to the subsystems that had long been consolidated under the Ministry of the Economy and the Ministry of Public Works. The window of opportunity for advancing in environmental issues was constituted by the postPinochet democratic transition. An emerging ecologist movement participated with the democratic opposition and managed to set the topic in the transition agenda (Silva, 1996). Their cause was aided by the international context with the Río 1992 Summit, where the United Nations Framework Convention on Climate Change was approved. But the international dimension was above all present in Chile's aspiration to become part of North American Free Trade Agreement (NAFTA), which imposed environmental requirements as a condition for membership. These international pressures for environmental policy change were coming at the beginning of Chile's strategy of international integration that the country pursues until today, in which environmental protection is merely instrumental. The lower priority on the substance of environmental policy as opposed to its optics also helps explain why the new system is part of a compromise between sectoral preoccupation and deeper regime orientations, which could share a short-time goal but not the same vision or goals. Indeed, the main objective of President Aylwin was economic growth (Silva, 1996), above environment, as he made clear in a speech he gave in 1992:

Environmental conservation cannot be considered in a restrictive meaning. Our country requires to satisfy growing needs in housing, health, education, energy, etc. This involves putting to work the resources that it counts on. Environmental protection cannot be considered in a trade-off with development, but as one of its components.

(Aylwin, 1992, pp. 6-7, cited in Campos-Medina \& Larenas, 2012, translation by the authors)

The priorities of the government, together with the drop in social mobilization (Carruthers, 2001), led to a political accommodation, in which civil society demands were incorporated, but with no harm for business groups (Silva, 1996). The concern for the environment had been institutionalized in a subsystem, but subordinated to the imperative of economic development (Tecklin et al., 2011). 
The set of regulations following the first one is a manifestation of institutional development of the subsector. Environmental evaluation and certification of new projects by the state progressively became a more sophisticated administrative process, as showed by Decree 95, which modified the regulation of the SEIA. It established the definitions of protected area, execution of project or activity and modification of project or activity and technical specifications of impact evaluations, such as the formal steps of an evaluation, the components of a report, or the channels to hand information to public authorities. However, these guidelines did not prevent the emergence of new social conflicts over extraction.

\section{Emerging conflicts and a latent institutional crisis}

The general public became quickly aware that the creation of new organizations and the institution of the evaluation process did not solve the environmental problems, as shown by the results of an opinion poll by the Centro de Estudios Públicos in 2000. When asked, "do you think that Chile is doing more than enough, the right effort, or too little", more than $80 \%$ answered "too little" (Centro de Estudios Públicos, 2001). More important that public opinion polls, however, for the re-emergence of the environment on the public agenda was the major negative environmental impacts caused by projects that had successfully passed the evaluation process.

The first important environmental conflict occurred during the Frei presidency, which followed the Aylwin presidency in 1994. The construction of the hydroelectric plant "Ralco" in the Bío-Bío River, which would strongly affect Pehuenches communities, was approved in 1997, even though some of the public authorities had stated their opposition during the evaluation process (Carruthers \& Rodríguez, 2009). The contestation of the project through protests and legal instruments followed until the plant went into operation, in 2004, and even if it did not manage to stop it, it contributed highly to illuminating the issues of ethno-cultural and biodiversity losses, which in turn questioned the extractive orientation of the economic model (Risley, 2015).

However, opinions that criticized the economic model were marginalized by became to be known as the Frei doctrine. ${ }^{4}$ President Frei publicly talked about "balancing the economic growth process of the country with environmental protection" (Frei, 2003) but at the same time promulgated a Presidential Directive that would lead to a pre-approval of all projects in the SEIA (González, 2006). This inclination towards accepting new investments at any cost is well illustrated in other conflicts such as La Farfana or the Black Swans. La Farfana is a water treatment plant in Maipú launched in 2003. The smell it emitted had not been mentioned during the evaluation process. The company was condemned for the damages it caused to more than 400 people (Farías \& Aveggio, 2009).

The Black Swans case that began in 2004 in Valdivia was a tipping point in the local environmental conflicts. The spilling of residues by Forestal Arauco in the Cruces river triggered a dramatic decrease in the swan population from 8,000 to 400 in one year (Sepúlveda \& Villarroel, 2012). The project started 
in 1995 when the Celco-Arauco company sent a proposal to the SEIA. The COREMA (Comisión Regional del Medio Ambiente, responsible for the official environmental review) at first rejected the project, worried by the pollution that could happen in the Cruces River. It was President Frei who put direct political pressure on the COREMA so that they would approve the environmental permits. That is why the mobilization, local, national and international, targeted the environmental institutions as responsible for the situation.

All these cases make clear the tension between a formal environmental subsystem that gave few guarantees for environment and population protection, and a permanent push for more extractive investment. Thus, during this time, the protection of the environment was subject to the regime that was favored by political and economic actors.

\section{Apparent policy change and regime resilience: the second wave of ecological modernization}

In 2010, the most significant change in environment institutions since the $1990 \mathrm{~s}$ occurred with the enactment of Law 20417, which established the Environment Ministry, the Environmental Assessment Service and the Superintendence of the Environment. Two years later, in 2012, Law 20600 establishing the Environmental Courts was enacted. This legislation set up three new courts, distributed geographically in the North, Center and South of the country. These new institutions are the culmination of the redesign of the environmental subsector that began in 2008, when President Bachelet sent the bills that created them to Congress.

In a general view, the transformation of the environmental system responds to a process of incremental change via sedimentation, in which various factors (Orihuela \& Paredes, 2017) and various actors (Madariaga, 2018) have influenced the growth of institutions gradually and differentially.
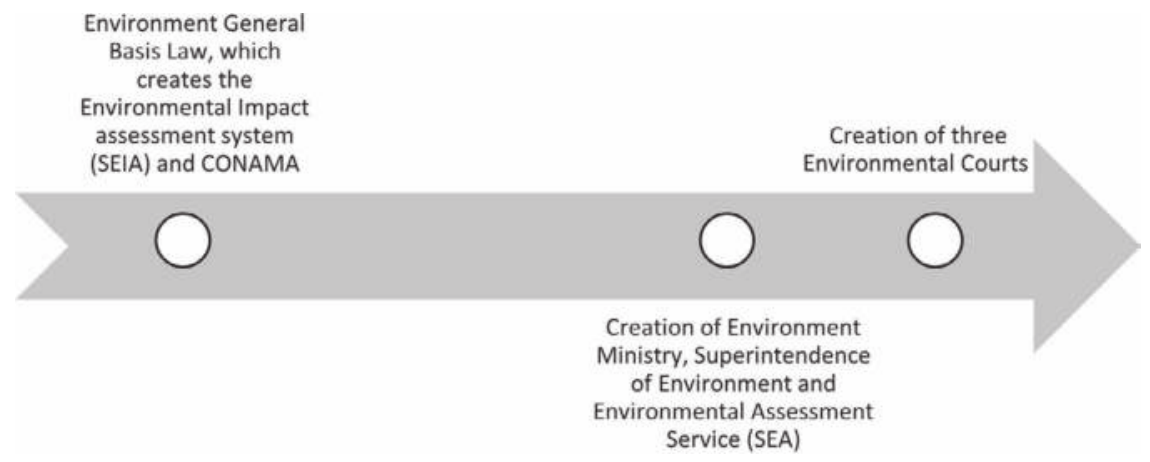

Figure 9.1 Two decades of environmental policy

Source: Own elaboration 
In the first place, the different social movements that began to be articulated since the 1990 s created a transversal support for environmental protection and generated a crisis of legitimacy of the system. This was expressed mainly in a critique of the political role that CONAMA played in the approval of environmentally damaging projects (Barandiaran, 2016).

Secondly, there was also international pressure to generate changes in the system. In the 2000s, the OECD criticized environmental regulations in Chile for their weakness, which constituted a strong external demand to transform the environmental system that existed in the country (Barandiaran, 2016; Tecklin et al., 2011). Specifically, the OECD made recommendations to improve environmental policy, which were a necessary condition for the country to become a member of the organization (Sepúlveda \& Villarroel, 2012).

Thirdly, there are domestic political factors that explain this transformation. In the 2005 presidential elections, very different presidential candidates committed themselves to an institutional change in the environmental field. This concern for the environment was expressed in a transversal way by the different political sectors, which gave an account of the relevance that the subject had acquired. Even Sebastián Piñera, who was the presidential candidate of the political right at that time, made environmental protection one of the main axes of his presidential program (Gamboa \& Segovia, 2006). This way, the environment was established as an electorally relevant issue in domestic politics, which was undoubtedly essential for the subsequent reform of the system (Tecklin et al., 2011). After winning the presidential election, President Michelle Bachelet renewed her commitment to the issue, leading the formulation of the new environmental policy, which ultimately resulted in the establishment of the MMA (the Ministry of Environment), the SMA (the Superintendence of Environment) and the Environmental Courts.

This analysis of formal changes in the environmental subsystem is, however, only one side of the story of Chilean environmental institutions. While these formal changes may be the most visible feature, they did not transform the extractive policy regime that persisted after these reforms.

\section{The persistence of the extractive policy regime}

To illustrate the persistence of the extractive policy regime-as opposed to apparent change in the environmental subsystem - we build on three strands of evidence: aggregated data of extractive projects in Chile, insights from specific conflict cases and budget evidence of the weak position of the environmental institutions in the Chilean state.

\section{Extractive projects in Chile: continuity in the policy regime}

The mining industry has become a key sector for investment of national and transnational capital. Given this, economic elites have developed "a new set of political technologies for expanding extractivism's socio-spatial frontiers" 
(Leiva, 2019, p. 145). In the territories, mining companies have established a capitalist domination at the local level, maintaining support through clientelism (Amengual, 2018) and even defeating the communities that oppose mining projects (Leiva, 2019).

In this section, we present data about the evolution of the mining investment in Chile that allows us to argue about the continuity of the policy regime, despite the apparent institutional changes that developed in the subsystem. We do this analysis in two ways. On the one hand, we observe the decisions taken by the environmental authority regarding the different mining projects. On the other hand, we analyze the investment dynamics to which the sector has been subjected, with special emphasis on the wild fluctuations since the 1990s.

The approval or rejection of investment projects depends on the assessment carried out by the Environmental Assessment Service (SEA). According to the Environment General Basis Law (Law 19300), this assessment "determines whether the environmental impact of an activity or project conforms to current regulations". In general, this tool has two main objectives, one technical and one political. First, it seeks to prevent and/or mitigate the negative externalities of the projects under evaluation. Secondly, the environmental impact assessment intends to limit environmental conflicts, involving citizens in the early stages of the process (Sepúlveda, 2000).

Figure 9.2 show the status of mining projects since the 1990s. As can be seen, only a very marginal percentage have been rejected by environmental regulation (only $4 \%$ ), while the majority of the projects have been approved. Overall, it can be determined that virtually all projects are approved, so the preventive role of environmental assessment is questioned. At the same time, $17 \%$ of the projects have been withdrawn by the project owners. This percentage is consistent with socio-territorial conflicts, where local actors have prevented investment projects to be carried out.

Figure 9.3 shows mining investments in Chile. In the 1990s, the investment of the mining projects amounted to approximately $12,000 \mathrm{MM} \$$. Already in the

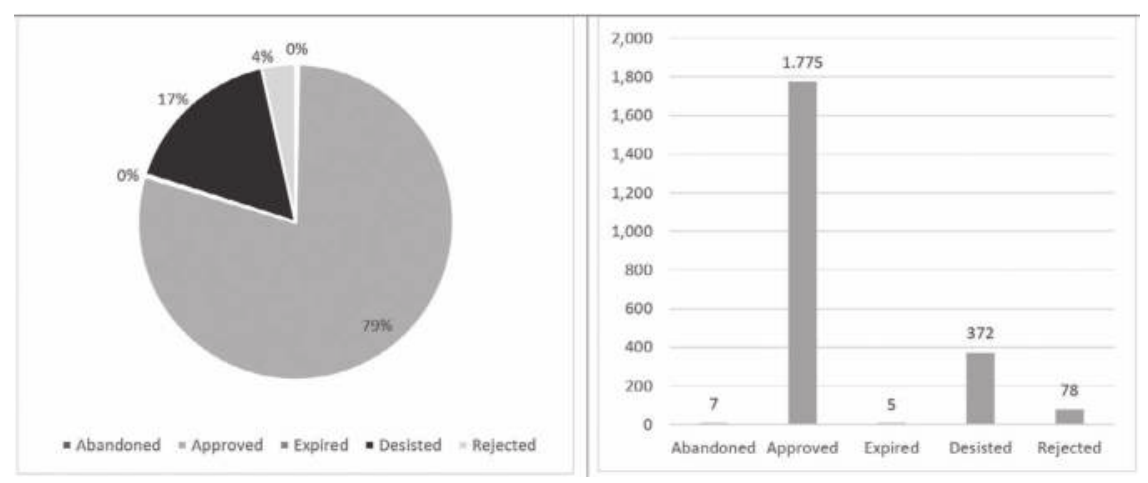

Figure 9.2 Status of mining projects in Chile (1993-2019)

Source: Authors' elaboration based on SEA data 


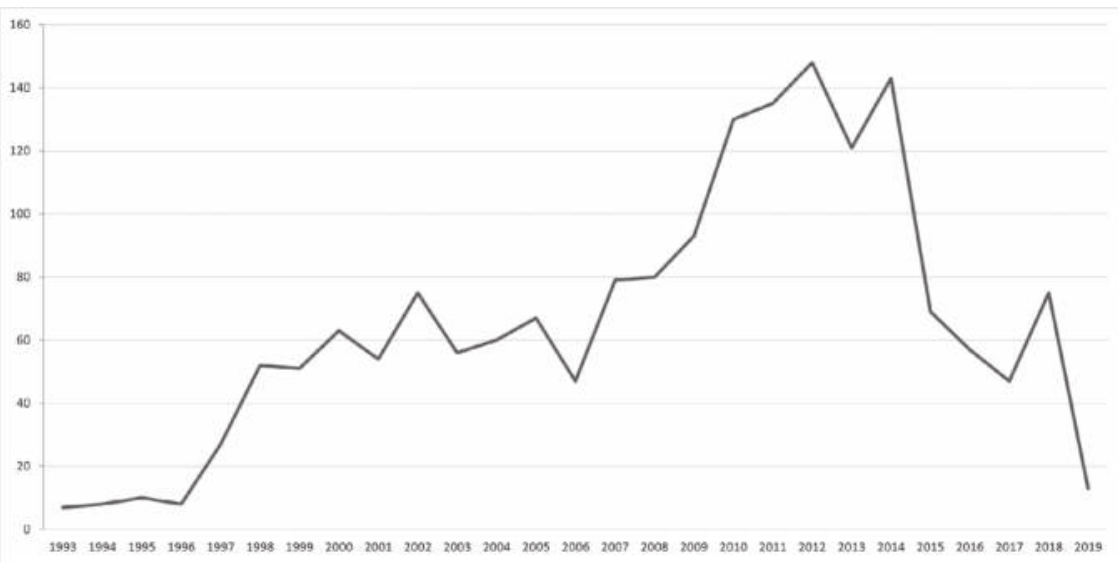

Figure 9.3 Number of mining projects approved by year

Source: Authors' elaboration based on SEA data

2000 s that number increased twice, reaching an amount close to $25,000 \mathrm{MM} \$$. Then that figure continued to increase significantly-reaching more than $35,000 \mathrm{MM} \$$ only between 2010 and 2014 . However, the investment would have a sharp decline from 2014, maintaining a downward trend in recent years. Therefore, the data we present about investment in the mining industry shows that business dynamics have followed cyclical behavior patterns, at least in terms of investment, since the 1990s. In other contexts, changes in environmental institutions have had an impact on investment. In fact, some countries have directly sought to restrict mining activity — as in Ecuador — or even ban it —as in El Salvador (Spalding, 2018). In contrast, in Chile, despite changes in environmental institutions, the industry has followed the dynamics of international economic forces.

As can be seen in Figure 9.3, the number of approved mining projects has gone up and down over the decades, reaching its highest point during the first government of President Sebastián Piñera (Figure 9.4), despite the new environmental institutions having already begun operations. This increase in investment follows the cycles of international commodity prices.

Figure 9.4 illustrates well how the regulations have not reduced investments, despite threats from the industry to respond to new regulations by ending investments. Also, the political authorities have insistently promoted investment, delivering messages to global investors about the legal certainty prevailing in Chile for the development of projects. As an example, in 2013 President Piñera, regarding the Pascua Lama project, pointed out that: "All Canadian investors can be sure that in Chile we have a democratic system and the rule of law is the one who will decide and make the decision on this investment" (EFE, 2013 [translation by the authors]). 


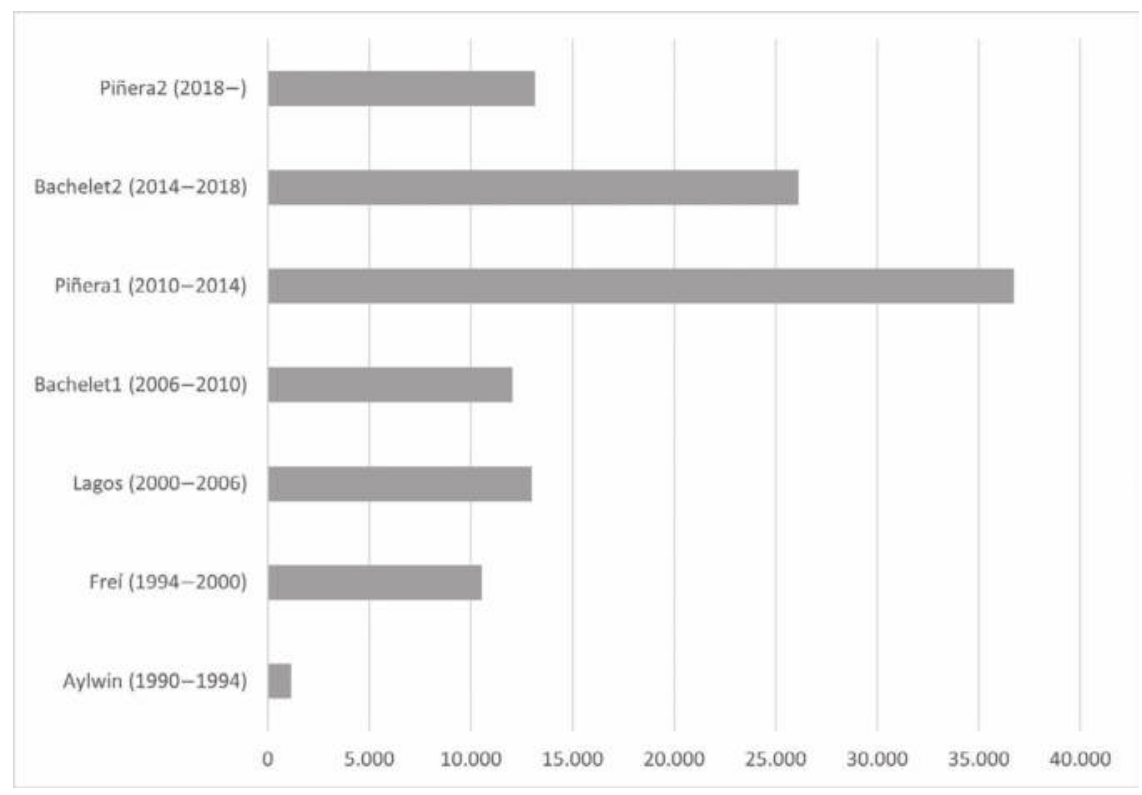

Figure 9.4 Investment amounts mining projects approved according to presidential term (in Chilean MM\$)

Source: Authors' elaboration based on SEA data

In recent years, socio-territorial conflicts have increased progressively in Chile, and conflicts over large-scale mining have come to play a leading role (Delamaza et al., 2017). While some of these conflicts have managed to block certain investment projects, the data presented in this section show that mining investment patterns are driven by extractive dynamics rooted in a context of global capitalism.

Although this chapter does not go deeper into the role of firms, mining firms clearly are using various resources in developing countries to attempt to legitimize themselves in communities (Amengual, 2018). In this sense, Chile has not been the exception (Leiva, 2019). Therefore, this general characterization of mining investment in Chile accounts for two phenomena. In the first place, it points out the approach that the Chilean environmental institutions have taken, by consistently approving mining-based investment projects. Second, it states that investment dynamics respond to exogenous factors rather than to local political and administrative institutions, moving according to international shocks. Business groups as well have generated an active lobby in opposition to state regulations since the return to democracy (Madariaga, 2018). In the case of environmental regulation, despite the opposition of important social movements, in many cases business interests prevailed. Thus, even if there was 
a strong push at the subsystem level, especially with the window of opportunity that the OECD opened, there was also a strong resistance, at the regime level.

Business power in Chile plays a strong role particularly in that it is not only strong in policy changes, but also strong in the implementation phase (Maillet \& Carrasco, 2019). As the establishment of extractive regimes-based on the exploitation of natural resources-generates various conflicting dynamics between the state, communities and companies (Falleti \& Riofrancos, 2018), business groups also manage lobby strategies to reverse the decisions of administrative bodies within the framework of the environmental institutions. For example, some of the few cases where investment projects have been rejected have generated great consternation in the business community. On the subject of a recent case that was rejected by the state, the president of the National Society of Mining stated:

Making investments becomes much more uncertain, because deep down in these projects, as one develops them, spending increases, and when it reaches the moment when the authority has to approve or not approve the resolution of environmental impact, if this is negative, everything that has been advanced is lost. Companies and investors, just to protect the investment they are making, try to do it in the most serious way possible, otherwise it would be a risky attitude.

(Peña \& Vergara, 2017 [translation by the authors])

This quote is typical of the discourse pervasive in business concerning the weight environmental regulation has on their projects, even though our data shows that these regulations are mainly business-friendly.

\section{Environmental policy under pressure: high-profile conflicts versus general trend}

Several high-profile conflicts reveal the ongoing tension between the environmental subsector and the extractive regime in Chile.

Protests over environmental issues intensified under Sebastián Piñera's presidency, as typified by the massive protests against the approval of a mega dam (Hidroaysén) in Chilean Patagonia for the production of hydroelectric energy (Silva, 2016, 2018). The protests began throughout different cities of Chile one day after the project had been approved by the regional COREMA for Coyhaique. Later on, they were articulated in an environmental campaign-Patagonia without Dams - that reached international dimensions and, finally, motivated the Committee of Ministers to reject the project in 2014 (Schaeffer, 2017). In that case, the political dimension of the decision was open, contrary to the alleged technical nature of the decision.

Two cases show that the new environmental institutions remained exposed to political pressure just after being launched. In August 2010, important mobilizations were registered against a thermoelectric project, 
Barrancones, which, if built, would have been located a few kilometers from the Pingüino de Humboldt natural reserve, in the fourth region of the country. The government resolved the case at the time by intervening directly in the process, asking the company for the relocation of the project, even though it had just been approved through the SEIA. The political intervention of the president is an extreme example of political meddling in an environmental institution (Sepúlveda \& Rojas, 2010). Technical and professionalized institutions, decisions remained subject to complex social and political dynamics.

A recent relevant case is the Dominga mining project. On August 21, 2017, the Committee of Ministers, the appeal body of the environmental institutions, rejected the Dominga mining project in the Coquimbo region. The decision was based on insufficient mitigation measures and received votes against the project from the ministers of the Environment, Public Health and Agriculture, while those of Energy and Mining voted in favor and the minister of Economy abstained. The proximity of this initiative to the Humboldt Penguin National Reserve gave rise to serious objections by different environmental groups over many years. In spite of this, the project was supported by the economic ministers, since it meant a strong investment that would bring important economic benefits for the area and the country (Madariaga, 2018). President Michelle Bachelet supported the minister of the Environment, which generated a crisis within the cabinet, resulting in the resignation of the minister and the undersecretary of Finance, as well as of the minister of Economy.

Some see this episode as a turning point in the country's environmental trajectory, because environmental concerns were privileged over investment and economic growth (Madariaga, 2018). However, it could also have been rather a short-term operation, motivated by the communicational objective of building a legacy for that presidency in environmental matters. Regarding this situation, Hermann Von Mühlenbrock, the president of the business peak association Sociedad de Fomento Fabril (Federation of Chilean Industry, SOFOFA), stated that:

I have always thought that investment projects should be rejected by technical observations, but when it is done through social reflections and as those that were heard today by the authorities in charge of the vote on the Environmental Qualification Resolution, I would like to know who can explain to Chileans with few resources and with few job options, that they will remain the same and that this will remain their reality, due to the rejection of projects like Dominga that bring nothing but development to the country.

(Paleo, 2017 [translation by the authors])

The confrontation between subsector regulation and regime aspiration are thus manifest in this case. ${ }^{5}$ 


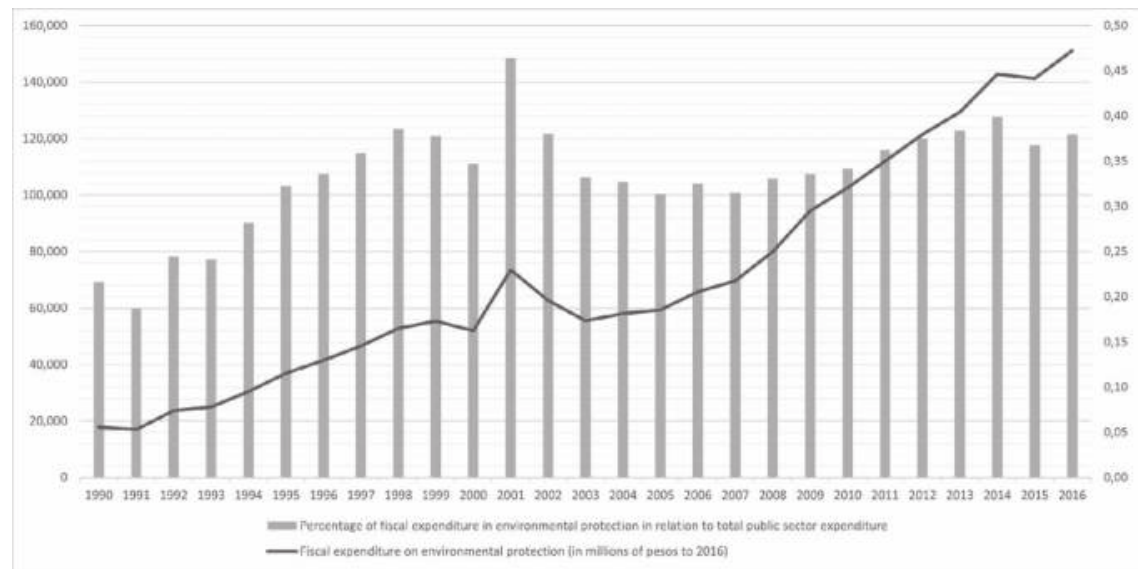

Figure 9.5 Evolution of fiscal expenditure in environmental protection (percentage and real values)

Source: Authors based on Madariaga's (2018) data

\section{Budget evidence of the weak position of environmental institutions}

As stated earlier, there is reasonable doubt that change in the environmental subsystem has been transformative. An analysis of public spending on the environment supports this argument. Madariaga (2018) has observed that public spending has increased an average of $8.3 \%$ annually since 1990 . It constitutes $2 \%$ over the average increase in the national budget. However, the argument about the increase in environmental protection spending can be nuanced, as Figure 9.5 shows.

The graph allows two readings - either enthusiastic or cautious. The positive view emphasizes the progressive increase in public spending on environmental protection from the return to democracy to the present day. On the other hand, its share of total public expenditure has remained at a low level (between $0.2 \%$ and $0.4 \%$ ). Therefore, the main findings based on the data analyzed is that the development of environmental spending in Chile has been rather marginal. This context coincides with a policy regime that has been maintained, notwithstanding important formal institutional changes that have taken place in the last decade at the subsystem level.

\section{Conclusion}

Environmental policies in Chile were formulated with a free market approach, in which the exploitation of natural resources remained ideologically and politically consolidated, keeping the environmental institutions virtually unchanged for 15 years (Tecklin et al., 2011). The institutional reforms in the 
environmental sector implemented during 2010 constitute for many a "lost opportunity" (Sepúlveda \& Villarroel, 2012). Therefore, since progress has not been seen in the legitimization and democratization of environmental decisions, socio-environmental conflicts will continue to persist (Sepúlveda \& Villarroel, 2012). In this way, it is observed that different institutional problems related to the regulation of business activity persist. The limits of citizen participation ${ }^{6}$ and the technical weaknesses of regulatory instruments are a good example of that.

Furthermore, it is possible to observe this failure not only in specific political discussions between different high-level political actors and in their intervention on projects with environmental impact, but also in areas such as social conflict, and in the increase of socio-environmental conflicts in Chile (Delamaza et al., 2017). This observation verifies the argument raised in this chapter: while changes in policy subsystems develop, global patterns that promote economic growth rather than environmental protection are nevertheless maintained as well. This is what constitutes an apparent change in the context of the policy regime as opposed to a substantive change, where clear limits to extractive activities would be set and development alternatives would be explored. Even though there has been an ecological modernization in the country, it is not transformative of the policy regime, keeping the natural resources curse as a constant feature. The new formal institutions themselves continue to reinforce the established extractive patterns and their impacts on the environment and territories. These findings confirm what some have raised as the continuity of neoliberalism in Chile (Madariaga, 2018), although this time in the environmental field.

While in Chile environmentalists may have won some battles, where the state finally withdrew support for emblematic extractive projects, they have not won the war. This trajectory can best be understood as the product of a persistent policy regime that prevails over apparent changes in the environmental subsystem. Hence, the dynamics of environmental governance must be understood in its confrontation with the deeply resilient power of a longstanding project of economic growth and a persistent extractive development regime.

\section{Notes}

1 This work was supported by National Agency for Research and Development [grant number ANID/FONDAP/15130009]; National Agency for Research and Development [grant number ANID/FONDAP/15110009]; and National Agency for Research and Development [grant number ANID/FONDECYTREGULAR/ 1180496]. Our thanks to Valentina Cariaga, Merry Hernández, Nicolás López and Francisco Martínez, all students from Public Administration at Universidad de Chile, for their valuable research assistance. Our appreciation to Bettina Schorr and Gerardo Damonte who helped us to improve the manuscript with their comments.

2 In this work, we use alternatively as synonyms the term subsystem from the discourse mostly in the United States, and the term sector from the discourse mostly in Europe.

3 Gellert has theorized the extractive regime based on the case of Indonesia (Gellert, 2010). Nem Singh and Bourgoin use it, but without an explicit definition (Nem Singh \& Bourgoin, 2013). 
4 This term was coined by environmental activists critical of Frei's stance on the environmentversus-growth dilemma, as stated by environmental leader Sara Larraín (González, 2006).

5 The final interpretation of this case requires some caution. A few weeks after the Committee of Ministers decision, the company appealed to the environmental court, which ruled that the process had to be brought back to an early stage, at the regional level, and the Supreme Court is at this time analyzing this decision.

6 In projects with environmental impact, early participation is practiced voluntarily and usually turned into an instance for negotiation. Participation is loose and focused on driving forward companies' projects rather than promoting democracy. There is little involvement of government officials in the process and little control over how well information are gathered and processed (Ocampo-Melgar et al., 2019)

\section{References}

Amengual, M. (2018). Buying stability: The distributive outcomes of private politics in the Bolivian mining industry. World Development, 104, 31-45. https://doi.org/10.1016/j. worlddev.2017.11.008

Barandiaran, J. (2016). The authority of rules in Chile's contentious environmental politics. Environmental Politics, 25(6), 1013-1033. https://doi.org/10.1080/09644016.2016.1218156

Campos-Medina, F. (2019). Ecological modernization from the actor's perspective: Spatiotemporality in the narratives about socio-ecological conflicts in Chile. Time \& Society, 28(3), 1239-1271. https://doi.org/10.1177/0961463x17752284

Campos-Medina, F., \& Larenas, J. (2012). La despolitización del conflicto socio-ecológico en la legislación medioambiental chilena a partir de los años noventa. Bitacora Urbano Territorial, 21(2), 45-56.

Carruthers, D. (2001). Environmental politics in Chile: Legacies of dictatorship and democracy. Third World Quarterly, 22(3), 343-358. https://doi.org/10.1080/01436590120061642

Carruthers, D., \& Rodríguez, P. (2009). Mapuche protest, environmental conflict and social movement linkage in Chile. Third World Quarterly, 30(4), 743-760. http://doi. org/10.1080/01436590902867193

Centro de Estudios Públicos-CEP. (2001). Estudio nacional de opinión pública. Crecimiento y medio ambiente (Documento de trabajo No. 320). CEP.

Delamaza, G., Maillet, A., \& Martínez-Neira, C. (2017). Socio-territorial conflicts in Chile: Configuration and politicization (2005-2014). European Review of Latin American and Caribbean Studies, 104, 23-46. https://doi.org/10.18352/erlacs.10173

EFE. (2013, May 30). Piñera en Canadá: Barrick tiene que cumplir reglas medioambientales en Pascua Lama. In La Segunda Online. www.lasegunda.com/Noticias/Politica/2013/05/851784/ Pinera-en-Canada-Barrick-tiene-que-cumplir-reglas-medioambientales-en-Pascua-Lama

Falleti, T., \& Riofrancos, T. (2018). Endogenous participation: Strengthening prior consultation in extractive economies. World Politics, 70(1), 86-121. https://doi.org/10.1017/ S004388711700020X

Farías, C., \& Aveggio, P. (2009, May 4). Empresa sanitaria deberá pagar $\$ 2.500$ millones de indemnización por caso La Farfana. La Tercera. www.latercera.com/noticia/empresa-sanitariadebera-pagar-2-500-millones-de-indemnizacion-por-caso-la-farfana

Frei, E. (2003, September 25). La política de medio ambiente de Chile. El País. https://elpais. com/diario/2003/09/25/sociedad/1064440806_850215.html

Gamboa, R., \& Segovia, C. (2006). Las elecciones presidenciales y parlamentarias en Chile, diciembre 2005-enero 2006. Revista de Ciencia Política (Santiago), 26(1), 84-113. https:// doi.org/10.4067/S0718-090X2006000100005 
Gellert, P. K. (2010). Extractive regimes: Toward a better understanding of Indonesian development. Rural Sociology, 75(1), 28-57. https://doi.org/10.1111/j.1549-0831.2009.00001.x

González, C. (2006, July 25). Ecologista: 'doctrina Frei’ le hace mal al país en materia ambiental. Chile Sustentable. www.chilesustentable.net/ecologista-doctrina-frei-le-hace-mal-al-paisen-materia-ambiental/

Halpern, C., \& Jacquot, S. (2015). Aux frontières de l'action publique: L'instrumentation comme logique de (dé)sectorisation. In L. Boussaguet, S. Jacquot, \& P. Ravinet (Eds.), Une "French touch" dans l'analyse des politiques publiques? (pp. 57-84). Presses de Sciences Po. https://doi.org/10.3917/scpo.bouss.2015.01

Haslam, P. A. (2016). Overcoming the resource curse: Reform and the rentier State in Chile and Argentina, 1973-2000. Development and Change, 47(5), 1146-1170. https:// doi.org/10.1111/dech.12259

Heikkila, T., Berardo, R., Weible, C. M., \& Yi, H. (2018). A comparative view of advocacy coalitions: Exploring shale development politics in the United States, Argentina, and China. Journal of Comparative Policy Analysis: Research and Practice, 21(2), 1-16. https://doi. org/10.1080/13876988.2017.1405551

Jochim, A., \& May, P. J. (2010). Beyond subsystems: Policy regimes and governance. Policy Studies Journal, 38(2), 303-327. https://doi.org/10.1111/j.1541-0072.2010.00363.x

Leiva, F. (2019). Economic elites and new strategies for extractivism in Chile. European Review of Latin American and Caribbean Studies, 108, 131-152. https://doi.org/10.32992/ erlacs.10511

Lira, J. (2017). Revisión y propuestas para el sistema de evaluación de impacto ambiental en Chile (Serie Informe Económico No. 267). Libertad y Desarrollo. https://lyd.org/wp-content/ uploads/2017/12/SIE-267-Revision-y-propuestas-para-el-Sistema-de-Evaluacion-deImpacto-Ambiental-en-Chile-Octubre17.pdf

Madariaga, A. (2016). Mechanisms of neoliberal resilience: Comparing exchange rates and industrial policy in Chile and Estonia. Socio-Economic Review, 15(3), 1-24. https://doi. org/10.1093/ser/mww015

Madariaga, A. (2018). From "green laggard" to regional leader: Explaining the recent development of environmental policy in Chile. Bulletin of Latin American Research, 38(4), 453-470. https://doi.org/10.1111/blar.12841

Mahoney, J. (2000). Path dependence in historical sociology. Theory and Society, 29(4), 507-548. www.jstor.org/stable/3108585

Mahoney, J., \& Thelen, K. (2010). A theory of gradual institutional change. In J. Mahoney \& K. Thelen (Eds.), Explaining institutional change. Ambiguity, agency and power (pp. 1-37). Cambridge University Press.

Maillet, A., \& Carrasco, S. (2019). Regulación y poder empresarial: El caso del transporte público en Santiago (2007-2017). Revista de Administraçao Publica, 53(5), 942-959. https:// doi.org/10.1590/0034-761220180079

Maillet, A., \& Rozas Bugueño, J. (2019). Hibridación de las políticas neoliberales. El caso de la reforma a la política eléctrica en Chile (2014-2016). Gestión y Política Pública, 28(1), 207-235. https://doi.org/10.29265/gypp.v28i1.546

May, P. J., \& Jochim, A. E. (2013). Policy regime perspectives: Policies and governing. Policy Studies Journal, 41(3), 426-452. https://doi.org/10.1111/psj.12024

Meyer, J. W., Frank, D. J., Hironaka, A., Schofer, E., \& Tuma, N. B. (1997). The structuring of a world environmental regime, 1870-1990. International Organization, 51(4), 623-651.

Muller, P. (2009). Sector. In L. Boussaguet, S. Jacquot, P. Ravinet, \& P. Muller (Eds.), Diccionario de políticas públicas. Universidad Externado de Colombia. 
Nem Singh, J., \& Bourgoin, F. (Eds.). (2013). Resource governance and developmental States in the Global South. Palgrave Macmillan. https://doi.org/10.1057/9781137286796

Ocampo-Melgar, A., Sagaris, L., \& Gironás, J. (2019). Experiences of voluntary early participation in environmental impact assessments in Chilean mining. Environmental Impact Assessment Review, 74, 43-53. https://doi.org/10.1016/j.eiar.2018.09.004

Orihuela, J. C. (2014). Converging divergence: The diffusion of the green State in Latin America. Studies in Comparative International Development, 49, 242-265. https://doi. org/10.1007/s12116-013-9147-6

Orihuela, J. C., \& Paredes, M. (2017). Fragmented layering: Building a green State for mining in Peru. In J. C. Orihuela, E. Dargent, M. E. Ulfe, \& M. Paredes (Eds.), Resource booms and institutional pathways (pp. 97-117). Springer International Publishing. https:// doi.org/10.1007/978-3-319-53532-6_4

Paleo,D. (2017,March 10). Lasreacciones delosempresariosentornoal rechazode Dominga. ElDía. www. diarioeldia.cl/economia/dominga/reacciones-empresarios-en-torno-rechazo-dominga

Paredes, M. (2016). The glocalization of mining conflict: Cases from Peru. The Extractive Industries and Society, 3(4), 1046-1057. https://doi.org/10.1016/j.exis.2016.08.007

Peña, K., \& Vergara, T. (2017, March 17). Hernández ante rechazo a Dominga: "Mientras más arbitrariedad, más me pone en duda seriedad del pais”. Diario Financiero. www.df.cl/noticias/ economia-y-politica/gremios-laboral/hernandez-ante-rechazo-a-dominga-mientrasmas-arbitrariedad-mas-se/2017-03-16/195321.html

Pierson, P. (2004). Politics in time. History, institutions, and social analysis. Princeton University Press.

Pierson, P. (2015). Power and path dependence. In J. Mahoney \& K. Thelen (Eds.), Advances in comparative-historical analysis (pp. 123-144). Cambridge University Press.

Risley, A. (2015). Civil society organizations, advocacy, and policy making in Latin American democracies: Pathways to participation. Palgrave Macmillan. https://doi.org/10.1057/9781137502063

Schaeffer, C. (2017). Democratizing the flows of democracy: Patagonia sin represas in the awakening of Chile's civil society. In S. Donoso \& M. von Bülow (Eds.), Social movements in Chile: Organization, trajectories, and political consequences (pp. 131-160). Palgrave Macmillan. https://doi.org/10.1057/978-1-137-60013-4

Sepúlveda, C. (2000). El proyecto Celulosa Valdivia: La legitimidad del sistema de evaluación de impacto ambiental puesta en juego. In F. Sabatini, C. Sepúlveda, \& H. Blanco (Eds.), Participación ciudadana para enfrentar conflictos ambientales. Desafíos para el sistema de evaluación de impacto ambiental (pp. 23-57). Centro de Investigación y Planificación del Medio Ambiente, CIPMA.

Sepúlveda, C., \& Rojas, A. (2010). Conflictos ambientales y reforma ambiental en Chile: Una oportunidad desaprovechada de aprendizaje institucional sobre participación ciudadana. Revista Ambiente y Desarrollo, 24(2), 15-23.

Sepúlveda, C., \& Villarroel, P. (2012). Swans, conflicts, and resonance: Local movements and the reform of Chilean environmental Institutions. Latin American pespectives, 39(4), 181-200. https://doi.org/10.1177/0094582x12441519

Silva, E. (1996). Democracy, market economics, and environmental policy in Chile. Journal of Interamerican Studies and World Affairs, 38(4), 1-33. https://doi.org/10.2307/166257

Silva, E. (2016). Patagonia, without dams! Lessons of a David vs. Goliath campaign. The Extractive Industries and Society, 3(4), 947-957. https://doi.org/10.1016/J.EXIS.2016.10.004

Silva, E. (2018). Mega-Projects, contentious politics, and institutional and policy change: Chile, 1994-2017. European Review of Latin American and Caribbean Studies, 106, 139-162. http://doi.org/10.32992/erlacs.10391 
Spalding, R. J. (2018). From the streets to the chamber: Social movements and the mining ban in El Salvador. European Review of Latin American and Caribbean Studies, 106, 49-79. https://doi.org/10.32992/erlacs.10377

Streeck, W., \& Thelen, K. (2005). Beyond continuity: Institutional change in advanced political economies. Oxford University Press. ISBN: 978-0-19-928046-9

Tecklin, D., Bauer, C., \& Prieto, M. (2011). Making environmental law for the market: The emergence, character, and implications of Chile's environmental regime. Environmental Politics, 20(6), 879-898. https://doi.org/10.1080/09644016.2011.617172

World Bank Group. (2019). Region profile of Latin America and Caribbean: Doing business 2019. World Bank. www.doingbusiness.org/content/dam/doingBusiness/media/Profiles/ Regional/DB2019/LAC.pdf 


\title{
10 Strengthening or weakening environmental institutions?
}

\author{
Chile and the establishment and \\ use of environmental courts in an \\ extractive economy
}

Violeta Rabi and Fernando Campos ${ }^{1}$

\section{Introduction}

The political assumption behind the resource curse or the paradox of plenty proposes that rent-seeking or windfalls in national economies dependent on the extraction and export of natural resources may have a detrimental effect on the robustness of existing regulatory institutions; the implementation and consolidation of institutional reforms; or even democratic quality in terms of transparency and participation (Auty, 1993). While research has confirmed these effects, this chapter aims to reinterpret the resource curse's political dimension (Brunnschweiler \& Bulte, 2008) and assess its applicability in cases that display a different institutional trajectory. To this end, our study explores the evolution and performance of the environmental institutions in Chile.

As an extractive economy, Chile's institutional evolution may suggest strengthening regulations, closer to what the ecological modernization theory proposes (Mol, 1997) or, as Bebbington (2010) states, a case where the extractive industry contributes to modernization and development. In fact, over the last three decades (1993-2019), Chile has experienced social processes that may even be regarded as counterintuitive if seen from a resource curse perspective. Parallel to the mining industry's highest growth and the copper price boom, there have been significant institutional changes seeking to improve environmental policy instruments' availability. Nevertheless, institutional strengthening has been put into question by implementing a market-enabling model rather than a market-regulation one (Tecklin et al., 2011) and by the lack of participatory institutions, similar to what has been seen in other Latin American countries (Falleti \& Riofrancos, 2018).

During the 1990s and 2000s, there was an unprecedented increase in foreign investment within the mining sector due to the return to democracy and the provision of legal stability to capital (Martínez \& Díaz, 1997). Though the price of copper was not exceptionally high, its contribution to GDP rose to about $10 \%$, even during complex economic contexts such as the 1998 Asian financial crisis. Likewise, the mining super-cycle saw an increase in copper's price from US $\$ 1$ /pound during the early 2000 s to a record high of US $\$ 4.6$ /pound in 2008 
(Álvarez et al., 2017). Thus, the price boom reinforced the extractive model and the idea that Chile can only achieve development as a mining country.

During the same period, the design and implementation of two major environmental reforms were executed. The official discourse proposed both of them as measures that would provide a clear set of rules for investors (Olivares, 2010; Guiloff, 2011).

The first transformation emerged as the result of the enactment of the Environmental Framework Act in 1994 and the entry into force of the Environmental Impact Assessment System (EIAS) as a mandatory step for the implementation of projects in 1997 (Moraga, 2010; Ulianova \& Estenssoro, 2012; Cordero et al., 2017). This reform was driven by the measures compelled in the 1992 Rio Convention. Hence, at the national level, international influence played a crucial role in the institutional transformations. The inclusion of compulsory public participation during the environmental impact assessment of particular projects, for instance, was a way to implement principle 10 of the Rio Convention, which demanded the right to public participation during decision-making processes conducted by the state. However, it was not until the second reform in 2010 that other aspects of this principle, such as access to information and environmental justice, came into play.

Global and subnational factors drove this second reform. On the international front, Chile's accession to the OECD meant reconsidering a series of recommendations laid out in an environmental report from 2005 that recommended strengthening the hierarchy of the environment sector at the state level (Sepúlveda \& Rojas, 2010; CNID, 2017). Locally, the collective pressure exerted by massive socio-environmental movements reflected the increasing public awareness about mega-project installation and its socio-environmental impacts (Pizarro, 2007; Sepúlveda \& Rojas, 2010). The most relevant cases were the protest against the construction of the Ralco hydroelectric plant in Mapuche territory in 1997, the Pascua Lama mining project in the Atacama Region and the pollution of a protected area of the Cruces River in Valdivia in 2004, and the emergence of national opposition to the construction of five hydroelectric plants in the Patagonia region as part of the Hydroaysén project in 2011.

As a result of the last reform, the Ministry of the Environment replaced the National Commission for the Environment (Comisión Nacional de Medio Ambiente, CONAMA). Additionally, three new agencies were created: The Superintendence of the Environment (Superintendencia de Medio Ambiente, SE), the Environmental Courts (ECs, Cortes Ambientales) and the Environmental Assessment Service (EAS, Servicio de Evaluación Ambiental). These entities were launched in 2012 (Cordero, 2010; Guiloff, 2010) to strengthen, oversee, and audit operations. The SE's function was to ensure compliance with existing environmental management instruments, while the ECs enabled citizens to challenge state decisions if they were deemed inappropriate.

Our research analyzes the operation of the ECs in Chile. Using these courts as a case study is highly relevant, as they may be understood from two opposite perspectives. On the one hand, they grant non-governmental actors access to 
environmental justice. On the other hand, the ECs offer project holders the possibility of challenging the state's environmental decisions. By analyzing the ECs' performance, we believe that the contradictions between the resource curse interpretations and the ecological modernization approaches may be explained. To this end, the ECs are explored at two levels: institutional design and implementation.

The results of this analysis suggest that institutional weakness and the sluggishness in the implementation of institutional reforms within extractive economies are not always directly related to the high income generated from the sale of natural resources but are somewhat due to more complex interactions between the performance of institutions and the social actors who use them. Indeed, institutional space may be regarded as a disputed territory whose dynamics may be addressed by the notion of institutional colonization, understood as social actors' capacity to influence institutional environments to introduce specific practices and ideas (Boltanski, 2012).

The chapter is divided into five sections. The introduction is followed by a theoretical framework where the resource curse and the ecological modernization institutional perspectives are presented. Afterwards, we develop the concept of institutional colonization for Chile, where a convergence exists between the export-oriented boom and institutional development. The third section briefly describes the method employed and the main characteristics of the ECs. The fourth section shows the results of the study. It is divided into four parts: the origin and institutional design of the ECs, the actors involved in the ECs, the cases heard in the ECs and the outcomes of the trials. The final section concludes and suggests further research possibilities.

\section{Chile: between the resource curse and ecological modernization perspectives}

There is a wealth of international literature on the paradox of plenty, which dates back to its emergence during the 1990s (Auty, 1993; Sachs et al., 1995). The analysis of these works reveals that efforts have been focused on explaining why the abundance of natural resources does not ensure countries' economic development (Ross, 2015). In this approach, regulatory institutions, which are theoretically in charge of mobilizing public resources from extractive activities to national development, become - in the best-case scenario-insufficient orin the worst-case scenario-corrupted (Olavarría, 2003). Likewise, this inability to transfer public funds for the benefit of the population is not reversed during times of prosperity; on the contrary, it becomes an even more acute problem. Therefore, the political dimension behind the paradox of plenty may predict institutional weakening episodes during commodity super-cycles since state bureaucracies have less incentive to regulate and adopt instead a laissez-faire approach.

On the other hand, and parallel to the research on the paradox of plenty, sociologists have been trying to make sense of the emergence of environmental 
institutions observed in industrial processes within developed economies (Jänicke, 2017, 2020). The ecological modernization theory predicts and promotes industrial and institutional transformation with a specific focus on environmental protection by linking investment and profits with cleaner industrial processes.

Even though the ecological modernization theory focuses on developed or post-industrial countries (Mol \& Sonnenfeld, 2014), it is difficult to argue that a theory that explicitly addresses modernization processes and socioenvironmental demands can be self-restricted to a small group of states and, therefore, to a small fraction of the world's population. In this sense, it is safe to say that most nations have transformed their institutional frameworks according to a sustainability approach, based on technological improvement, entrepreneurship promotion, and market-based solutions over the last three decades (Foladori, 2005). In this context, institutional transformation is triggered by the growing need and urgency to incorporate sustainable measures into production and consumption models. From an ecological modernization perspective, this means that companies and the states might reduce the negative impacts generated by their productive activities and benefit from impact reduction processes by putting adequate market incentives in place and participating in multilateral negotiations to improve environmental conditions worldwide, as part of the so-called international environmental governance (Buttel, 2003).

The utility of describing both theories is that they reveal two opposite evaluations of institutional performance. Chile presents a challenge to both understandings: its institutions have not been severely affected by the resource curse, and the two waves of institutional modernization (described in the introduction) have not been entirely oriented towards environmental protection.

Although the reforms of Chilean environmental institutions involved creating a series of procedures aimed at promoting public participation in investment decision-making processes and enabled access to environmental justice, the analysis of how these so-called technical procedures actually work inevitably leads us to a more critical position. Indeed, the same period in which environmental institutions have been reformed showed an unprecedented increase in extractive activities (Altieri \& Rojas, 1999), the rise of socio-environmental conflicts (Delamaza et al., 2017), and the extreme cases of socio-environmental impacts in sacrifice areas ${ }^{2}$ (Bolados \& Sánchez-Cuevas, 2017).

Therefore, it can be argued that current institutional transformations have not contributed to relieving pressure on the environment and local populations. Dramatic cases such as the ownership of water rights, which are controlled by powerful groups (Bauer, 2002; Larraín, 2007); the intensification of polluting activities in already degraded territories (Cortés et al., 2016); and questionable socio-environmental compensation methods in exchange for social consent (the so-called social license) to operate mega-projects (Chile Transparente, 2018) are all allowed and legitimized within the Chilean institutional setting. 
The previous may sound contradictory under the assumption that the lack, or weakening, of institutions is the main reason behind socio-environmental issues. However, our study argues that existing regulatory systems foster socio-environmental pressure on an important number of local communities and ecosystems. Therefore, institutional frameworks should be examined to explore the reasons behind the emergence of contemporary forms of socioenvironmental suffering (Auyero \& Swistun, 2008, 2013), which exist not only in the lack or weakening of regulatory institutions but also in their implementation. We propose to analyze this dynamic drawing on the concept of institutional colonization.

This concept describes how institutional designs, created for socially agreed purposes and in line with legally discussed procedures, are jeopardized or destabilized by specific groups who use them for their interests. In this sense, colonization processes should be explored in terms of institutional design and implementation.

Following this concept, the ECs cannot be immediately associated with institutional improvement due to greater access to environmental justice. On the contrary, we argue that the legal system cannot be regarded only as a guarantor of environmental justice. Instead, it can be understood as a space intended to legitimize socio-environmental tensions resulting from the multiple interests of different social groups. ECs provide a platform for catalyzing socio-environmental conflicts, and the concept of institutional colonization represents the struggles between different powers converging in this process. Hence, aspects such as the actors involved and the decisions issued by the ECs are elements that contribute to the analysis of the performance of these courts.

\section{Methodology}

The study is based on secondary information, systematized and analyzed to explore the emergence and operation of the ECs in Chile. The history of Acts No. 20.417 and $20.600^{3}$ enabled us to describe the social conditions under which the new institutional framework was designed. Furthermore, the analysis of legal cases considered by the ECs provided detailed information on who was involved in litigation and how the courts reached their decisions. This data was obtained from an inspection of electronic files on the ECs' website and recorded and organized in a qualitative database. ${ }^{4}$ Further information was obtained from state organizations through transparency requests.

ECs are specialized legal bodies mostly in charge of ruling on contentious administrative cases; they oversee compliance with normative procedures. Since, in terms of competence, legal claims are the center of ECs, our research will focus on them. Legal claims ${ }^{5}$ accounted for $77.3 \%$ of total cases (184) and triple the number of environmental damage claims. In this way, the resolution of contentious administrative issues was the subject of most of the 238 cases handled by the ECs (see Table 10.1). 
Table 10.1 Total cases processed by the environmental courts (ECs)

\begin{tabular}{llcr}
\hline Year & $\begin{array}{l}\text { Claims of } \\
\text { environmental } \\
\text { damage }\end{array}$ & Legal claims & Total \\
\hline 2013 & 7 & 20 & 27 \\
2014 & 10 & 46 & 56 \\
2015 & 15 & 45 & 60 \\
2016 & 22 & 73 & 95 \\
Total & $\mathbf{5 4}$ & $\mathbf{1 8 4}$ & $\mathbf{2 3 8}$ \\
\hline
\end{tabular}

Source: Database compiled by the authors with data from EC 2013-2016, available in the websites of the three courts: http://2ta.lexsoft.cl/2ta/search?proc $=4$ and https://causas.3ta.cl/.

Types of legal claims recognized by the ECs are listed as follows in Act No. 20.600: ${ }^{6}$

No. 1: Cases against executive orders establishing primary or secondary regulations on environmental quality and emission standards, declaring latent, or saturated areas and establishing prevention or decontamination plans (Article 17, subparagraph 1);

No. 3: Cases against resolutions issued by the Superintendence of the Environment if they do not comply with legislation, regulations or other relevant legal provisions, as well as against the imposition of fines (Article 17, subparagraph 3);

No. 5: Against resolutions rejecting or establishing conditions or requirements on Environmental Impact Statements (EISs) or Environmental Impact Assessments (EIAs) or rejecting review requests regarding Environmental Assessment Authorization (Resolución de Calificación Ambiental, RCA in Spanish) (Article 17, subparagraph 5);

No. 6: Against the fact of disregarding the observations made by citizens during the mandatory public participation process of the environmental impact assessment process (Article 17, subparagraph 6);

No. 7: Against administrative actions taken by ministries or public services regarding the enforcement or implementation of quality and emission standards and prevention and decontamination plans if they contradict the law, rules or objectives of the instruments mentioned above (Article 17, subparagraph 7); and

No. 8: Against resolutions determining the invalidation of environmental administrative procedures (Article 17, subparagraph 8).

For the study, the different users identified as claimants are:

I Project holders, which are divided into private companies, public companies and state bodies; 
II Indigenous communities;

III Civil society grassroots organizations, such as neighborhood councils, trade associations, and environmentalist organizations;

IV Persons who go to court either individually or collectively and do not fall into previous categories due to the temporary nature of their organizations, which are associated with specific interests;

$\mathrm{V}$ Companies that do not own disputed projects;

VI Democratically elected representatives, such as council officials, members of Congress and regional councilpersons.

\section{Results}

\section{Origins and operation of the ECs}

Initially, the ECs were not considered part of the 2010 environmental institutional reform. They emerged during parliamentary discussions when right-wing politicians expressed their distrust of the extensive vigilance and sanctioning powers of the new Superintendence. For various reasons, the idea of creating the ECs was endorsed by environmental NGOs, as they recognized the need to have adequate access to justice for socio-environmental issues. Therefore, to adopt Act No. 20.417, the executive and members of the parliament signed a memorandum of understanding to create a specialized environmental jurisdiction under the Supreme Court's direct control (Plumer, 2013).

In line with the previous, the Act No. 20.600 of 2012 created the ECs per the following four considerations: judicial control over decisions issued by environmental administrative authorities; control should be handled by specialist rather than generalist judges; these courts should be composed of expert staff in legal and technical areas; given their specialized and unique nature, these courts should issue predictable decisions, thus providing legal certainty for all parties involved.

Hence, the parliamentary negotiations acknowledged the idea that the powers of the ECs would not be restricted to addressing decisions issued by the Superintendence of Environment but also expanded to anything regulated by the Environmental Act (Act No. 19.300), which would allow access to environmental justice in a wide range of matters (Library of the Chilean National Congress, 2010). However, despite the expansion of the matters for which it is competent, the administrative litigation ECs' scope produces a bias towards procedural reviews. Indeed, the ECs focus on settling the legality of applying environmental management instruments, regulations and administrative actions associated with them. In other words, the primary role of the ECs is to assess whether authorities have infringed the procedures established by law, dealing with claims or objections regarding the legality of actions or sanctions emanating from the administration (Bermúdez, 2016). Unregulated natural elements by Act No. 19.300, such as land planning, water, or forest resources, do not fall within the domain of these courts. 
Furthermore, only a restricted category of actors can appeal to the ECs. In this respect, Moraga (2012) explains that the Act's final text was more restrictive than the original proposal. She argues that reasons for admission are always connected to specific actors. For example, only citizens who have participated in the public consultation during the environmental impact assessment can present a legal claim against the accuracy or sufficiency of the environmental assessment agency's response. The previously mentioned implies that citizens who did not have the chance to participate in this previous instance are prevented for this reason from using the court even if they consider that their interests have not been guaranteed.

In sum, the parliamentary negotiations review shows that the ECs were created for counterbalancing the powers granted to the SE. Ultimately, the final design of the ECs focused on the formal monitoring of procedures aimed at ensuring the regular operation of existing environmental management instruments-regulations, plans, environmental assessment-rather than on the provision of legal tools to ensure environmental protection as an end in itself. Additionally, the instruments addressed by the ECs explicitly restrain the array of actors who may use them in specific cases, limiting the access and type of environmental justice to one that is bounded and procedural.

\section{Who takes cases to ECs?}

This section analyzes which kind of parties have appealed to the ECs to resolve environmental controversies. The data shows that claims have been filed in the first place by private companies and natural persons (see Table 10.2). When taking the project holder category (adding private and public companies and state bodies) and the non-project holder category (the rest of the categories described in Table 10.2) as a whole, both turn to the courts to an equal extent, 92 cases each. Despite this, the positions of these two groups are not necessarily the same. In the case of project holders, they emerge as actors with the specific interest of ensuring implementation of their investment projects. This is not the case for the rest of the users since the non-project holder category encompasses different interests and positions.

While indigenous communities and environmental organizations aim at defending local territories and specific ecosystem and cultural conditions, grassroots organizations turn to courts for a variety of concerns, ranging from the protection of the environment or specific resources (such as water) to the protection of economic activities (as in the case of fishing associations). The non-project holder category also includes representatives from other than the project holder companies who are affected by the implementation of investments. This is the case, for instance, with agricultural companies filing claims against mining companies. Finally, it is challenging to identify natural persons' interests, ranging from ecological or quality of life concerns to economic interests.

Another form used to categorize the type of users is the distinction between organized civil society and non-organized civil society, which is based on identifying 
Table 10.2 Number of legal claims by type of user

\begin{tabular}{lcc}
\hline Type of user/type of action & Legal claims & Total \\
\hline Project Holder (Private Company) & 82 & $44.6 \%$ \\
Individuals & 37 & $20.1 \%$ \\
Grassroots Organization & 20 & $10.9 \%$ \\
Indigenous Community & 12 & $6.5 \%$ \\
City Council & 7 & $3.8 \%$ \\
Other Complaining Company & 7 & $3.8 \%$ \\
Project Holder (State Company) & 6 & $3.3 \%$ \\
Socio-Environmental Organization & 5 & $2.7 \%$ \\
Representative of Popular Election & 4 & $2.2 \%$ \\
Project Holder (State Body) & 4 & $2.2 \%$ \\
Total & $\mathbf{1 8 4}$ & $\mathbf{1 0 0 \%}$ \\
\hline
\end{tabular}

Source: Database compiled by the authors with data from EC 2013-2016 (references in Table 10.1).

Note: The total considers cases both closed and pending.

collective and individual claims. There are 37 claims filed by indigenous communities, grassroots organizations, and environmentalist organizations (accounting for $20 \%$ of total claims) against the 44 claims filed by natural persons and other complaining companies ( $24 \%$ of total claims). There are also claims filed by public authorities, representing $5 \%$ of the total claims (see Table 10.2).

The claims filed to the ECs can also be classified according to the projects' distribution among economic sectors. The majority of them are associated with three: mining, energy and water, sanitation and hygiene (WASH). These sectors represent $24 \%, 22 \%$, and $14 \%$ of the total number of cases filed, respectively, which accounts for $60 \%$ of the country's total legal claims (see Table 10.3). In the two first categories, claims were presented by holders and non-holders of projects. Claims regarding the WASH sector are filed mostly by project holders.

As a general tendency, claims are filed by project holders to allow continuation of their investments. This suggests that most of the claims filed in the ECs are not intended to stop the implementation of projects, but rather to go ahead with them. Claims filed in equal numbers by project holders and non-project holders were only seen in specific economic sectors, especially in the case of energy and mining mega-projects that, according to the literature, are the sectors most prone to the emergence of socio-environmental conflicts (INDH, 2015).

\section{Which cases are heard in the ECs?}

The law stipulates that cases handled by the ECs are limited by two considerations: they can only handle claims that fall under the reasons stipulated by article 17 of Act No. 20.600, and only those with legal standing authorized by law can participate in these legal proceedings. 
Table 10.3 Legal claims by type of user and economic sector

\begin{tabular}{|c|c|c|c|c|c|c|c|c|c|c|c|c|}
\hline $\begin{array}{l}\text { Type of user/economic } \\
\text { sector }\end{array}$ & $\begin{array}{l}\text { Agriculture and } \\
\text { Livestock }\end{array}$ & Energy & Forestry & Industry & Real Estate & Mining & $\begin{array}{l}\text { Public } \\
\text { Works }\end{array}$ & $\begin{array}{l}\text { Fish } \\
\text { Farming }\end{array}$ & $\begin{array}{l}\text { Land } \\
\text { Planning }\end{array}$ & $W A S H$ & Other & Total \\
\hline Indigenous Community & 0 & 3 & 3 & 0 & 0 & 4 & 0 & 2 & 0 & 0 & 0 & 12 \\
\hline Grassroots Organization & 1 & 6 & 0 & 1 & 5 & 4 & 0 & 1 & 2 & 0 & 0 & 20 \\
\hline $\begin{array}{l}\text { Social Environmental } \\
\text { Organization }\end{array}$ & 0 & 3 & 0 & 0 & 2 & 0 & 0 & 0 & 0 & 0 & 0 & 5 \\
\hline $\begin{array}{l}\text { Other Complaining } \\
\text { Company }\end{array}$ & 1 & 3 & 0 & 1 & 0 & 2 & 0 & 0 & 0 & 0 & 2 & 7 \\
\hline Natural Persons & 0 & 10 & 2 & 0 & 4 & 10 & 5 & 2 & 0 & 2 & 0 & 37 \\
\hline $\begin{array}{l}\text { Representative by } \\
\text { Popular Election }\end{array}$ & 0 & 2 & 0 & 0 & 0 & 0 & 0 & 0 & 0 & 1 & 1 & 4 \\
\hline $\begin{array}{l}\text { Project Holder (State } \\
\text { Company) }\end{array}$ & 0 & 0 & 0 & 0 & 0 & 2 & 4 & 0 & 0 & 0 & 0 & 6 \\
\hline $\begin{array}{l}\text { Project Holder (Private } \\
\text { Company) }\end{array}$ & 8 & 9 & 0 & 7 & 8 & 22 & 1 & 3 & 0 & 20 & 4 & 82 \\
\hline
\end{tabular}

Source: Database compiled by the authors with data from EC 2013-2016 (references in Table 10.1).

Note: The total considers cases both closed and pending. Category "Other" is cases related to general norms of emissions. 
We divided the claims filed into three categories: claimant profile, the institution that was the subject of the claim, and reason for admission established by law (see Table 10.4). In general terms, with 95 and 72 cases each, the Superintendence of the Environment (SE) and the Environmental Assessment Service (EAS) account for the most significant number of legal actions taken against public entities (51\% and 39\% of total claims, respectively). While project holders from private companies only filed claims against the SE, legal actions against the EAS were taken by project holders, grassroots organizations, and natural people.

Regarding the grounds for making claims, out of 179 cases, reasons related to review the decisions made by the Superintendence of the Environment, No. 3 (87 cases) stands out as the primary motive. These claims are filed mainly by project holders who request a revision of the interim measures or sanctions imposed on them. On the other hand, non-project holders focus their claims on complaints, approval of compliance plans, and, to a lesser extent, sanctions. Though both project holders and non-project holders file requests for sanctions, the latter used this procedure when there was disagreement regarding the magnitude of the fines imposed, such as on the Pascua Lama and Caserones mining projects and the Bocamina thermoelectric project, arguing that they were too low.

Reasons related to invalidation of the procedures (No. 8) are the secondmost-used motive in legal claims, concentrating 46 cases. Although there are 14 cases where project holders addressed invalidation, this reason is mainly used by natural persons and grassroots organizations when filing claims against the EAS (12 and 9 cases each, respectively). On aggregate, this reason is used mainly by non-project holders (67\% of total claims), of which 15 came from organized civil societies, 13 from non-organized civil societies, and four from local government representatives (regional councils or municipalities).

Reason No. 6 refers to claims based on the observation of flaws detected by citizens during the public participation process. All of these claims challenge environmental assessments favorable for the companies. It is worth highlighting that reason No. 6 is less frequently used than the invalidation No. 8 (32 cases vs. 15 cases), as the former requires the submission of observations during the stages of public participation. This conditioning factor restricts the broadening of access to environmental justice.

In the context of restrictive rules to access to ECs, our analysis suggests that invalidation is the primary tool used by civil society to prevent projects from being authorized. This instrument is used since it is the only possibility that allows users to take action about issues that have not been included in the environmental impact assessment. It is, therefore, safe to say that members of the civil society interested in using the ECs should base their claims on invalidation grounds, having to demonstrate the occurrence of illegality during the process. This may distort the type of cases handled by the ECs, as the institutional setting requires them to look for a normative breach to obtain access to the ECs.

Lastly, reason No. 5 refers to claims against unfavorable or the conditional approval of the environmental impact. It is not surprising that project holders 
Table 10.4 Legal claims by type of claimant, respondent, and reasons from Article 17, 2013-2016

\begin{tabular}{|c|c|c|c|c|c|c|c|c|c|}
\hline Claimant [respondent]/Article 17 & No. 1 & No. 3 & No. 5 & No. 6 & No. 7 & No. 8 & $N / E$ & Total & $\%$ \\
\hline EAS & 0 & 0 & 1 & 2 & 0 & 4 & 2 & 9 & $5 \%$ \\
\hline Municipality & 3 & 0 & 2 & 0 & 0 & 2 & 0 & 7 & $3.9 \%$ \\
\hline Ministry of the Environment & 3 & 0 & 0 & 0 & 0 & 0 & 0 & 3 & $1.7 \%$ \\
\hline EAS & 0 & 0 & 2 & 0 & 0 & 2 & 0 & 4 & $2.2 \%$ \\
\hline $\begin{array}{l}\text { Organ with Environmental } \\
\text { Competence }\end{array}$ & 0 & 0 & 0 & 0 & 0 & 1 & 0 & 1 & $0.5 \%$ \\
\hline EAS & 0 & 0 & 0 & 1 & 1 & 8 & 0 & 10 & $5.6 \%$ \\
\hline ES & 0 & 7 & 0 & 0 & 0 & 0 & 1 & 8 & $4.4 \%$ \\
\hline $\begin{array}{l}\text { Socio-Environmental } \\
\text { Organization }\end{array}$ & 0 & 1 & 0 & 2 & 0 & 2 & 0 & 5 & $2.6 \%$ \\
\hline EAS & 0 & 0 & 0 & 1 & 0 & 1 & 0 & 2 & $1.1 \%$ \\
\hline ES & 0 & 5 & 0 & 0 & 0 & 0 & 0 & 5 & $2.8 \%$ \\
\hline Natural Persons & 2 & 11 & 2 & 9 & 0 & 12 & 1 & 37 & $20.6 \%$ \\
\hline
\end{tabular}


Ministry of the Environment

2
0

Organ with Environmental

Competence

EAS

ES

Representative by Popular

Election

EAS

ES

Project Holder (State

Company)

Organ with Environmental

Competence

\section{EAS}

ES

Project Holder (Private

Company)

Ministry of the Environment

Organ with Environmental

Competence

EAS

ES

Project Holder (Organ of the

State)

EAS

Total

0
0

0

0

0

0

1
1

0
0

Source: Database compiled by the authors with data from EC 2013-2016 (references in Table 10.1).

Note: The total considers cases both closed and pending, five legal claims included under the scope of Act No. 20.473 have been excluded from the database.

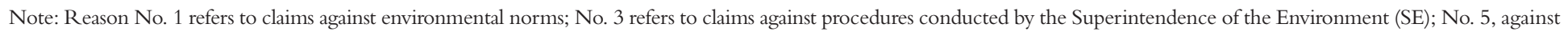

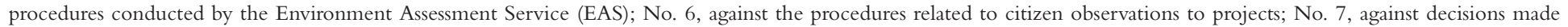
related to decontamination plans; and No. 8 refers to the general invalidation process. 
file almost all claims. However, this reason may also be used to request the revision of EIAs. In this case, claims may be filed by those directly affected by EIAs when the variables under assessment and monitoring have substantially changed once projects are already underway. In this last case, reason No. 5 is used to oppose investment projects. This has happened five times through claims filed by indigenous communities, local city councils and natural persons.

According to our results, there are restrictions in the institutional design of ECs that hamper access to justice for most communities. This problem becomes evident in our finding that organized communities represent only $21 \%$ of total claims. Likewise, only a limited number of complaints are filed by non-project holders against institutional entities for ignoring citizens' observations. As a whole, these cases and invalidation actions filed by the communities account for $26 \%$ of total claims. By contrast, claims presented by project holders represent $49 \%$ of total cases.

Most of the claims are filed by project holders, meaning that claims refer to projects already underway rather than projects under assessment. In this sense, the image being spread that civil society is halting projects through the use of the legal system is not entirely fair. The performance of the ECs shows that institutional rules privilege project holders to press their claims in court, while other citizens face several high barriers. The latter reinforces a structural asymmetry upheld by the institutional design, suggesting that the ECs are best understood as serving as a counterbalance to the SE.

\section{How do the ECs resolve disputes?}

In this section, we identify how the ECs resolved cases. From the 184 claims considered here, 141 were completed by the end of 2017 . Within this sample, 106 of these cases received a final judgment issued by the ECs. From this figure, 52 cases (49\% of total claims) concluded with a decision handed down by the ECs, and 54 cases (51\% of total claims) finalized with a ruling issued by the Supreme Court. This means more than half (54) of all cases completed in the ECs (106) were challenged by a cassation appeal, moving from a specialized court to a generalist one. Thirty-five cases concluded without a decision, most of them because they were deemed inadmissible by the court, or the claimants withdrew them.

At ECs, most of the 106 cases concluded were rejected (see Table 10.5); in other words, claimants lost at trial. This means that, regardless of the type of claimant, most of them received an unfavorable ruling. Out of the 69 claims rejected by the ECs, 38 were filed by project holders, and non-project holders filed 31 . As for the 18 claims approved by the ECs, both were filed equally by project holders and non-project holders.

It is worth noting that all claims made by indigenous communities, environmental social organizations and other complaining companies have been rejected. Regarding organized civil society, only two claims out of 18 were supported by the ECs; this contrasts with the nine claims won by project holders. 
Table 10.5 Claims by type of resolution

\begin{tabular}{|c|c|c|}
\hline Outcome of the cases in the ECs & Frequency & $\%$ \\
\hline Allowed & 18 & $16.8 \%$ \\
\hline Municipality & 2 & $11.1 \%$ \\
\hline Grassroots Organization & 2 & $11.1 \%$ \\
\hline Natural Persons & 5 & $27.8 \%$ \\
\hline $\begin{array}{l}\text { Project Holder-State } \\
\text { Company }\end{array}$ & 1 & $5.6 \%$ \\
\hline $\begin{array}{l}\text { Project Holder-Private } \\
\text { Company }\end{array}$ & 8 & $44.4 \%$ \\
\hline Allowed in Part & 20 & $18.7 \%$ \\
\hline Indigenous Community & 1 & $5.0 \%$ \\
\hline Municipality & 1 & $5.0 \%$ \\
\hline Grassroots Organization & 4 & $20.0 \%$ \\
\hline $\begin{array}{l}\text { Other Complaining } \\
\text { Company }\end{array}$ & 1 & $5.0 \%$ \\
\hline Natural Persons & 3 & $15.0 \%$ \\
\hline $\begin{array}{l}\text { Project Holder-Private } \\
\text { Company }\end{array}$ & 10 & $50.0 \%$ \\
\hline Rejected & 69 & $64.5 \%$ \\
\hline Indigenous Community & 7 & $10.1 \%$ \\
\hline Municipality & 1 & $1.4 \%$ \\
\hline Grassroots Organization & 4 & $5.8 \%$ \\
\hline $\begin{array}{l}\text { Socio-Environmental } \\
\text { Organization }\end{array}$ & 2 & $2.9 \%$ \\
\hline $\begin{array}{l}\text { Other Complaining } \\
\text { Company }\end{array}$ & 6 & $8.7 \%$ \\
\hline Natural Persons & 10 & $14.5 \%$ \\
\hline $\begin{array}{l}\text { Representative by Popular } \\
\text { Election }\end{array}$ & 1 & $1.4 \%$ \\
\hline $\begin{array}{l}\text { Project Holder-State } \\
\text { Company }\end{array}$ & 2 & $2.9 \%$ \\
\hline $\begin{array}{l}\text { Project Holder-Private } \\
\text { Company }\end{array}$ & 33 & $47.8 \%$ \\
\hline Project Holder-State Body & 3 & $4.3 \%$ \\
\hline Total & 106 & $100.0 \%$ \\
\hline
\end{tabular}

Source: Database compiled by the authors with data from EC 2013-2016 (references in Table 10.1).

Note: The total considers cases closed.

As for project holders, only 9 out of the 57 cases were approved by the ECs, and 38 were rejected. This means that most project holders lost at trial in ECs. However, they challenged the rejection of 14 claims, accounting for $36 \%$ of total cases. Once a cassation appeal was declared admissible by the Supreme Court, the number of successful claims doubled from 9 to 18. Therefore, it could be inferred the Supreme Court tends to accept cases brought by project holders and are likely to succeed in their appeal. 
In the organized civil society, only two claims were approved by the ECs, with 12 claims being rejected and five claims being allowed partially. Likewise, $75 \%$ of the rejected claims (9 cases) were challenged, but only one succeeded in the Supreme Court. When civil society claimants won at the ECs, these verdicts were appealed in the Supreme Court, with one of them being revoked. In total, civil society claimants won two cases and partially won another two cases. The comparison between these results and those received by project holders reveals a considerable gap: 18 successful cases against two successful cases.

\section{Conclusion}

The combination of descriptive and institutional analysis conducted throughout this study reveals that the rejection of projects resulting from non-project holders' claims before the ECs is a sporadic event.

It is likewise worth noting that, given the contentious administrative nature of this court, the only decision they can issue favoring non-project claimants is to reconsider cases from the moment that a procedural error took place. For instance, if invalidation is issued against an environmental assessment resolution, the court may order a reassessment of the project, but it may not ban the project's implementation in question. In this sense, it can be argued that neither the ECs nor the Supreme Court are institutions that allow civil society to control environmental assessment procedures. As for the Supreme Court's role, 8 out of 13 claims filed by non-project holders and rejected by the ECs were challenged by claimants, of which only two were allowed by the supreme tribunal. In practice, this resulted in two investment projects coming to a halt: the Achibueno hydroelectric plant, which was abandoned, and the salmon farms in Calcurrupe.

Much of the discussion around extractive economies' regulatory framework is guided by straightforward explanations on how state transformations intended to strengthen or weaken institutions. This chapter analyzed the design and operation of the ECs in Chile to illustrate how the performance of novel regulatory institutions can become detached from their fundamental normative values: in this case, ensuring and expanding access to environmental justice. This situation led us to propose the notion of institutional colonization to describe that the design and implementation of a regulatory institution are affected in its scope by the emergence of other orientations. Therefore, institutional colonization implies a redefinition of institutional goals in ECs, narrowing its mission.

It is important to point out that institutional colonization does not mean that social actors take total control of regulatory frameworks. Institutions do not become entirely instrumental or serve just one specific interest. As shown in this study, institutions are fields where different social interests enter into conflict, which reinforce the ideas held by institutional analysis (Powell \& DiMaggio, 1991; Boltanski, 2012). Therefore, institutions became factors that activate socio-environmental controversies and influence the power and strategies of different actors. 
In this regard, our study analyzed two different levels to describe institutional colonization: the design of the institutional framework and its factual operation. Both show how specific actors' interests permeate the institutions, moving them to decide in specific ways. At the design level, it is essential to highlight the supervision the ECs undertake on the Superintendence of the Environment. This institutional counterbalance role is fundamental when it comes to analyzing the operation of the ECs. According to the results of this study, most of the claims and successful cases are related to project holders who challenged the SE's decisions unfavorable to them.

The design of rules for filing legal claims before the ECs reveals a restrictive feature in terms of the issues that can be revised by these courts and who can access them. Related to the contents, ECs are mainly focused on existing environmental management instruments, showing a bias towards procedural rather than substantive aspects. According to some groups, the idea of expanding the powers of the ECs towards sectorial regulations is seen as an alternative in achieving institutional development, since one of their main weaknesses is the excessive formality in the handling of cases, disregarding values such as environmental quality and protection.

The focus on procedural justice implies that communities interested in access to these courts have to translate their challenges into cases of formal illegality in order to fit into the existing rules that organize the operation of ECs. This context could explain why invalidation is the most popular tool to access ECs among organized civil society. Another acknowledged institutional barrier is the lack of effective legal and technical guidance for filing claims against public services. It is also important to give attention to the fact that legal actions are taken because there is no other process to engage in, and this one involves long bureaucratic procedures and waiting times.

The powerful voices criticizing the excessive judicialization of investment projects due to socio-environmental considerations done by communities that are against them do not recognize the shallow rate of success for the civil society, environmentalist groups or indigenous communities when compared to project holders. The latter is true both at the ECs and Supreme Court. In this sense, despite all major Chilean business associations having spread the hypothesis that the continued obstruction to the construction of large projects has stifled private investment and economic growth through court proceedings, there is no evidence from the ECs to support this claim. On the contrary, use of the legal system to prevent projects from being implemented seldom accomplishes this goal, and instead merely increases the time and resources required for their construction.

In conclusion, creating new environmental institutions, such as the one designed in the Chilean environmental reform, is not necessarily enough to assume direct institutional strengthening. This depends on how instruments and procedures are planned, and more importantly, on how different actors use the institution.

Future studies may explore three research lines: first, in order to continue to test the judicialization hypothesis, to complement the study of ECs with the 
revision of socio-environmental cases issued at ordinary courts; second, the motivations and strategies deployed by relevant social actors in the ECs; and third, the content of the decisions issued by the ECs. This latter line of research would allow us to understand the type of arguments discussed in the courts and how specific substantive discussions are transformed by being addressed from formal perspectives, only to make discussions fit within the existing institutional frames. Additionally, the systematization of data on the limitations in access to information and comparisons with other Latin American experiences may shed light on the particular nature of the Chilean case and the potential use of the institutional colonization concept in other regulatory contexts.

\section{Notes}

1 This study was supported by the Fondo Nacional de Desarrollo Científico y Tecnológico (National Fund for Scientific and Technological Development), Fondecyt Iniciación, Chile, Grant No. 11160601, and it is based on the study "Derribando mitos: propuestas para mejorar el acceso a la justicia ambiental", conducted by Fundación Espacio Público with funds from the Embassy of Switzerland in Chile.

2 Sacrifice areas are places that have been historically impaired by heavy environmental damage, often through the concentration of locally unwanted land uses. Usually, these zones are located in low-income and vulnerable communities.

3 The Ministry of the Environment, the Environmental Assessment Service, and the Environment's Superintendence were established by Act No. 20417. The ECs were established by Act No. 20.600, which ordered the creation and implementation of three environmental courts in three supra-regional areas: the North, based in Antofagasta; the Center, based in Santiago; and the South, based in Valdivia.

4 All cases were individually registered and identified regardless of whether they referred to the same project or grouped for further deliberation.

5 Legal claims aim to revise administrative rules and procedures of the environmental public administration. Therefore, the ECs are in charge of determining the legality of measures taken by authorities.

6 ECs can also handle other matters: environmental damage (article 17, subparagraph 2) and authorization of provisional measures proposed by the Superintendence of the Environment (article 17, subparagraph 4). These are not analyzed in this study.

\section{References}

Altieri, M., \& Rojas, A. (1999). La tragedia ecológica del "milagro" neoliberal chileno. Persona y Sociedad, 13(1), 127-141.

Álvarez, R., García Marín, A., \& Ilabaca, S. (2017). Commodity prices shocks and poverty reduction in Chile. Serie de documentos de trabajo SDT 449. Universidad de Chile. http:// repositorio.uchile.cl/handle/2250/146333

Auty, R. M. (1993). Sustaining development in resource economies: The resource curse thesis. Routledge.

Auyero, J., \& Swistun, D. (2008). Inflamable: Estudio del sufrimiento ambiental. Paidós.

Auyero, J., \& Swistun, D. (2013). Expuestos y confundidos. Un relato etnográfico sobre sufrimiento ambiental. Íconos-Revista de Ciencias Sociales, 28, 137-152. https://doi. org/10.17141/iconos.28.2007.216

Bauer, C. (2002). Contra la corriente: Privatización, mercados de agua y el Estado en Chile. Lom Ediciones. 
Bebbington, A. (2010). Extractive industries and the stunted states: Conflict, responsibility and institutional change in the Andes. In R. Raman \& R. Lipschutz (Eds.), Corporate social responsibility: Discourses, practices and perspectives (pp. 97-115). Palgrave MacMillan.

Bermúdez, J. (2016). Fundamentos de derecho ambiental. Ediciones Universitarias de Valparaíso.

Bolados, G. P., \& Sánchez-Cuevas, A. (2017). Una ecología política feminista en construcción: El caso de las "mujeres de zonas de sacrificio en resistencia", Región de Valparaíso, Chile. Psicoperspectivas. Individuo y Sociedad, 16(2), 33-42. https://doi.org/10.5027/ psicoperspectivas-vol16-issue2-fulltext-977

Boltanski, L. (2012). Sociología y crítica social. Editorial Universidad Diego Portales.

Brunnschweiler, C. N., \& Bulte, E. H. (2008). The resource curse revisited and revised: A tale of paradoxes and red herrings. Journal of Environmental Economics and Management, 55(3), 248-264. https://doi.org/10.1016/j.jeem.2007.08.004

Buttel, F. (2003). Environmental sociology and the explanation of environmental reform. Organization and Environment, 16(3), 306-344. https://doi.org/10.1177\%2F1086026603256279

Chile Transparente. (2018). Riesgos de corrupción en concesiones mineras y otorgamiento de permisos ambientales: el caso de Chile. Informe del proyecto de minería para un desarrollo sostenible. Transparency Internacional. www.chiletransparente.cl/wp-content/files_mf/1517340532InformeMineriafull. compressed.pdf

Consejo Nacional de Innovación para el Desarrollo- CNID. (2017). Informe final. Evaluación de los conflictos socio-ambientales de proyectos de gran tamaño con foco en agua y energía para el periodo 1998 al 2015. www.cnid.cl/wp-content/uploads/2017/04/Informe-final-CNIDEvaluacio\%CC\%81n-de-Conflictos-Socioambientales-1.pdf

Cordero, L. (2010). La ruta del rediseño de la institucionalidad ambiental. In E. Aliste \& A. Urquiza (Eds.), Medio ambiente y sociedad. Conceptos, metodologías y experiencias desde las ciencias sociales y humanas (pp. 117-143). RIL Editores. http://repositorio.uchile.cl/ bitstream/handle/2250/118106/Aliste-y-Urquiza-2010-Medio-ambiente-y-sociedad. pdf?sequence $=1$

Cordero, L., Durán, V., Palacios, C., Rabi, V., \& Urquiza, A. (2017). Derribando mitos: Propuestas para mejorar el acceso a la justicia ambiental en Chile. Espacio Público.

Cortés, S., Molina, L. D. C., Burgos, S., Adaros, H., \& Ferreccio, C. (2016). Urinary metal levels in a Chilean community 31 years after the dumping of mine tailings. Journal of Health and Pollution, 6(10), 19-27. https://doi.org/10.5696/2156-9614-6-10.19

Delamaza, G., Maillet, A., \& Martínez, C. (2017). Socio-territorial conflicts in Chile: Configuration and politicization (2005-2014). European Review of Latin American and Caribbean Studies, 104, 23-46. https://doi.org/10.18352/erlacs.10173

Falleti, T., \& Riofrancos, T. (2018). Endogenous participation: Strengthening prior consultation in extractive economies. World Politics, 70(1), 86-121. https://doi.org/10.1017/ S004388711700020X

Foladori, G. (2005). Modernización ecológica, cambio tecnológico y globalización. Economía, sociedad y territorio, 5(18), 335-353. https://doi.org/10.22136/est002005308

Gerencia de Políticas Públicas y Desarrollo- SOFOFA. (2017). Catastro de proyectos de inversión. Sociedad de Fomento Fabril SOFOFA. http://app.sofofa.cl/indicadores/CPI/ Informe/CPI_2017.pdf

Guiloff, M. (2010). Reforma a la institucionalidad ambiental: un análisis desde el diseño institucional. In M. Guiloff, D. Hervé, \& R. Pérez (Eds.), Reforma a la institucionalidad ambiental: Antecedentes y fundamentos; programa de derecho y politica ambiental. Ediciones Universidad Diego Portales.

Guiloff, M. (2011). Nueva institucionalidad ambiental: hacia una regulación deliberativa. In J. Couso (Ed.), Anuario de derecho público 2011 (pp. 231-242). Ediciones Universidad Diego 
Portales. https://derecho.udp.cl/cms/wp-content/uploads/2020/06/Anuario-DerechoPublico-2011.pdf

Instituto de Derechos Humanos-INDH. (2015). Mapa de conflictos socioambientales en Chile. http://mapaconflictos.indh.cl/

Jänicke, M. (2017). Ecological modernization as global industrial revolution. Journal of Environmental Policy and Administration, 25, 1-32. https://doi.org/10.15301/ jepa.2017.25.S.1

Jänicke, M. (2020). Ecological modernization- a paradise of feasibility but no general solution. In L. Mez, L. Okamura, \& H. Weidner (Eds.), The ecological modernization capacity of Japan and Germany: Comparing nuclear energy, renewables, automobility and rare earth policy (pp. 13-23). Springer VS.

Larraín, S. (2007). El agua en Chile: Entre los derechos humanos y las reglas del mercado. Polis, Revista de la Universidad Bolivariana, 14, 1-17.

Library of the Chilean National Congress. (2010). Historia de la Ley No. 20417. Crea el ministerio, el servicio de evaluación ambiental y la superintendencia del medio ambiente. obtienearchivo. bcn.cl/obtienearchivo?id=recursoslegales/10221.3/3929/6/HL20417.pdf

Martínez, J., \& Díaz, A. (1997). Chile: The great transformation. Brookings Institution.

Mol, A. (1997). Ecological modernization: Industrial transformations and environmental reform. In M. Redclift \& G. Woodgate (Eds.), The international handbook of environmental sociology (pp. 138-149). Edward Elgar.

Mol, A., \& Sonnenfeld, D. (2014). Ecological modernization around the world: Perspectives and critical debates. Taylor and Francis.

Moraga, P. (2010). Más allá de la prevención: el principio de precaución. In E. Aliste \& A. Urquiza (Eds.), Medioambiente y sociedad. Conceptos, metodologías y experiencias desde las ciencias sociales y humanas (pp. 100-116). RIL Editores.

Moraga, P. (2012). Principio 10 y desarrollo eléctrico: participación y acceso a la justicia en miras a la implementación de tribunales especializados. Revista de Derecho de la Pontificia Universidad Católica de Valparaíso, 39, 291-317. http://doi.org/10.4067/ S0718-68512012000200011

Olavarría, M. (2003). Protected neoliberalism: Perverse institutionalization and the crisis of representation in post-dictatorship Chile. Latin American Perspectives, 30(6), 10-38. https://doi.org/10.1177/0094582X03256259

Olivares, A. (2010). El nuevo marco institucional ambiental en Chile. Revista Catalana de Dret Ambiental, 1(1), 1-23. https://doi.org/10.17345/1039

Pizarro, G. (2007). La reforma ambiental en Chile. Journal of Technology Management and Innovation, 2(2), 3-6. www.jotmi.org/index.php/GT/article/view/curr3

Plumer, M. C. (2013). Los tribunales ambientales: se completa la reforma a la institucionalidad ambiental. Anuario de Derecho Público, 297-315. derecho.udp.cl/wp-content/ uploads/2016/08/013_Plumer.pdf

Powell, W. W., \& DiMaggio, P. (1991). The new institutionalism in organizational analysis. University of Chicago Press.

Ross, M. (2015). What have we learned about the resource curse? Annual Review of Political Science, 18, 239-259.

Sachs, J. D., \& Warner, A. M. (1995). Natural resource abundance and economic growth. Working Paper 5398. National Bureau of Economic Research-NBER.

Sepúlveda, C., \& Rojas, A. (2010). Conflictos ambientales y reforma ambiental en Chile: Una oportunidad desaprovechada de aprendizaje institucional sobre participación ciudadana. Revista Ambiente y Desarrollo, 15-23. 
Tecklin, D., Bauer, C., \& Prieto, M. (2011). Making environmental law for the market: The emergence, character, and implications of Chile's environmental regime. Environmental Politics, 20(6), 879-898. https://doi.org/10.1080/09644016.2011.617172

Ulianova, O., \& Estenssoro, F. (2012). El ambientalismo chileno: La emergencia y la inserción internacional. Si Somos Americanos, 12(1), 183-214. https://doi.org/10.4067/ S0719-09482012000100008 


\title{
11 New institutions, old practices \\ The weakening of new environmental control institutions in Peru
}

\author{
Maritza Paredes and Lorena Figueroa
}

\section{Introduction}

The aim of this chapter is to explain the emergence and implementation of new environmental institutions in Peru in the most recent commodity boom cycle. More specifically, it seeks to answer why, in spite of these changes, the country is still reproducing a pattern of weak environmental institutions. The paper focuses on environmental control institutions, such as the Agency for Environmental Assessment and Enforcement (Organización de Evaluación y Fiscalización Ambiental, OEFA). This agency has been gravely damaged in the first decade of its operation, and today it faces serious challenges for achieving its goals. Meanwhile, in a recently published report, the Ombudsman's Office declared that 9,000 Peruvians have been exposed to heavy metals and polluting chemicals resulting from the waste of extractive industries in Peru. ${ }^{1}$

A growing literature explains the emergence of new environmental rules in the previous decade in Peru (Orihuela \& Paredes, 2017; Granados, 2016; Orihuela, 2014). In 2008, the government of Alan García approved new environmental legislation whose main change was to dismantle the previous fragmented cross-sectoral system. Previous rules dictated that each productive sector had an environmental office and was also responsible for regulating the quality of the environment in its own sector (Pulgar-Vidal, 2008). In the case of mining, for example, a specialized office called the Direction of Mining Environmental Management (Orihuela \& Paredes, 2017; Granados, 2016) carried out this responsibility within the Ministry of Mining and Energy (Ministerio de Energía y Minas, MINEM). It had little autonomy and resources. This cross-sectoral system was consolidated in the 1990s by the Fujimori government, which sought to favor the promotion of private investments in the exploitation of natural resources (Orihuela \& Paredes, 2017).

The creation of the Ministry of the Environment (Ministerio del Ambiente, MINAM) in 2008 brought the promise of a centralized, autonomous and technical system of environmental governance. ${ }^{2} \mathrm{New}$ rules were promulgated, including the creation of a technical organization to handle the control of environmental quality: the OEFA. The creation of the OEFA was thought to be the beginning of autonomous environmental governance without private 
interference, in particular in light of the doubts cast by communities impacted by mining regarding the MINEM's independence in making environmental decisions (Pulgar-Vidal, 2008; Lanegra, 2015).

Given these institutional innovations, one could argue that Peru's new environmental governance is a departure from the resource curse. This chapter argues that, unfortunately, this is not the case: there are new carafes, but the wine is still quite old. New formal institutions represent progress in the right direction to reduce environmental inequalities in the context of extractive exploitation. However, if daily activities and practices in organizations often have very little to do with the goal of the new formal institutions, these end up being "myth and ceremony" (Meyer \& Rowan, 1977). This chapter explains why isomorphic institutional change has produced limited results in the context of extractive environmental governance in Peru, and how the natural resource curse subtly persists in a more acceptable institutional scheme.

The argument puts forward two mechanisms. First, the forging of isomorphic institutional change often does not dismantle old and informal practices embedded in the governance of extractive industries, such as the influence of the mining and oil industry on the public sector. These practices survive and persist in spite of the new formal institutions, undermining them from the start and throughout their formation. Second, the formation of isomorphic institutional change can be assisted by the action of social movements or the mobilization of communities. Nonetheless, the process of creation of new institutions does not necessarily articulate social bases in a significant way that would allow the development of ownership over these new rules. Actors involved in the creation of these rules are often professional elites associated by epistemic values and beliefs (Orihuela \& Granados, 2021). The study provides empirical information to show how old practices, uncontested by social forces, undermine the coercive capacity and the shared benefit of new institutions. In the eyes of the people, these new rules are more of the same and are quickly discredited, repeating the pattern of weak institutions in Peru.

This chapter developed a case study in 2019 based on the revision of official documents, the media and interviews conducted between 2016 and 2018. Section 2 summarizes the institutional change in Peru in relation to environmental control. Section 3 develops the explanatory argument by showing evidence of the old practices that are maintained despite the new rules and how they undermine the capabilities and legitimacy of the new institutions. Finally, Section 4 concludes with some reflections.

\section{Institutional change and environmental protection in Peru: the OEFA}

This chapter addresses the institutional transformation of the rules of the game (North, 1990) in the environmental sector in the new commodity boom cycle. The analysis focuses on institutions for the protection of the environment in the context of extractive activities, such as mining and hydrocarbons. 
Both activities taken together have represented in the last decade about $70 \%$ of national exports. ${ }^{3}$

Institutional changes consisted in the transition from a cross-sectoral system in operation since the 1960 s to a centralized one, with the creation of the MINAM. The main problem with the old rules was the lack of autonomy. Environmental control of each type of industry was the purview of the same government sector in charge of promoting that particular industry. Thus, the MINEM was in charge of both promoting mining and hydrocarbons activities in the country as well as responsible for environmental protection in the sector. In addition to the problem of autonomy, environmental agencies within the ministries developed very different legislative bodies and capacities, making coordination between sectors problematic and generating confusion among the different state actors and society (Charpentier \& Hidalgo, 1999, p. 164). This old system was highly criticized by experts and communities that mobilized against extractive industries throughout the decade (Lanegra \& Hurtado, 2013).

Orihuela and Paredes (2017) suggest that during this period environmental protection rules evolved gradually by layers. ${ }^{4}$ The mining sector incorporated important environmental institutional expansions in the 1990s and early 2000s. An important milestone was the incorporation of the environmental impact assessment in mining in $1993 .{ }^{5}$ In addition, the MINEM, with the technical assistance of the Canadian Cooperation and the financial support of the World Bank, modernized the laws regulating concessions, licenses, exploration, exploitation and extraction in the sector (Pulgar-Vidal, 2008; World Bank, 2007). ${ }^{6}$ These legislative improvements, unfortunately, did not have effective consequences on the capabilities and actions of the unit in charge of environmental protection within the MINEM. The Mining Environmental Management Agency had limited human and budgetary resources and carried out its assignments from the desk (World Bank, 2007). This means that documentation presented by extractive companies was revised with little sense of the reality of the terrain.

The escalation of mining conflicts, with a peak in 2008, partly illustrates the discontent of communities with these environmental rules. However, both the industry and the MINEM resisted until the end to give up its environmental authority in order to build a centralized and external agency. Peru and Chile were laggards in the institutional transition to the ministry system. This transition had already taken place everywhere else in Latin America a decade before.

It was only under intense international pressure that the new environmental rules took their final form, a centralized and technical authority, the Ministry of the Environment. The emergence of the MINAM took place, paradoxically, in one of the most conservative governments since the Fujimori government. Alan García (2006-2011) was an open advocate of the expansion of the frontier for the exploitation of natural resources, in particular in the Amazon. His government faced one of the strongest conflicts of the new century with indigenous populations in the Amazon. ${ }^{7}$ New rules emerged despite the opposition of García and his allies. International pressure from transnational actors played a 
crucial role in the context of financial negotiation of bilateral and international agreements with the government, in particular the Free Trade Agreement with the United States (PTPA) and a second financial loan from the Inter-American Development Bank (IDB) for stage 2 of the Camisea project (Orihuela \& Paredes, 2017, Lanegra, 2015). In this process, the literature has highlighted the convergence of agendas of transnational actors with local allies and entrepreneurs, who knew how to take advantage of local political opportunities to effectively collaborate with these transnational agendas (Orihuela \& Paredes, 2017; Orihuela, 2014).

The interesting thing about the Peruvian case is that these institutional changes arrived despite the opposition and influence of the extractive industries. Thus, Peruvian institutional change responded much more to a diffusion of change supported by the transnational connection of actors in the environmental field and in multilateral organizations that managed to apply sufficient pressure on the government (Tarrow, 1998; Keck \& Sikkink, 1998).

Some of the social conflicts, whose protests escalated significantly to the international level, contributed to place the controversies surrounding the environmental control system in Peru under international scrutiny. For example, the World Bank and then the Inter-American Development Bank came under heavy pressure from transnational activists to use their influence on the Peruvian government to transform environmental institutions. Thus, the old formal rules were attacked and progressively lost legitimacy (Pulgar-Vidal, 2008) among the actors in the environmental field. As mentioned before, Peru was late in responding to the new demands and pressures that governments throughout the region were subject to. By then, most of the countries in Latin America had already progressively moved towards a centralized and leading authority, that is, to a Ministry of the Environment (Orihuela, 2014).

In the context of the financial loan negotiation for the second stage of the Camisea gas project and the FTA negotiations with the United States, multilateral agencies strongly influenced the change that the state had to make, in environmental matters, if it wanted to continue being their financial and commercial partner (Lanegra, 2015). Thus, the institutional transformation of environmental control in Peru must be understood more as a consequence of the global diffusion of new norms in a highly rationalized and global field, such as the environmental field (DiMaggio \& Powell, 1983), than a nationwide pushed institutional reform. The MINAM was strategically inaugurated on May 31, 2008 at a Latin America and the Caribbean and the European Union (LACEU) summit, where the participating governments adopted the Declaration of Lima, which put great emphasis on environmental problems (Larsen, 2010).

However, a decade later, the new rules and the OEFA show serious difficulties in achieving their objectives, as this chapter demonstrates with different data. Nonetheless, the most emblematic case illustrating the failure of the rules to protect the environment are the numerous oil spills of the North Peruvian Pipeline (ONP). This pipeline crosses through Loreto, Amazonas, Cajamarca and Piura for more than 850 kilometers and was built in 1977. Numerous spills have been recorded between 2008 and 2019, which have affected large areas 
of indigenous communities. Several professionals and experts, including the former Minister of the Environment, Manuel Pulgar-Vidal, argued that the spills were due to the lack of maintenance and corrosion of infrastructure as old as the pipeline.

\section{Isomorphic institutional changes and the persistent resource curse}

This chapter seeks to problematize the consequences of isomorphic institutional change. In contexts such as those in much of the developing world, strong formal institutions are the exception and not the rule, and the power of formal institutions should not be taken for granted (Murillo \& Levitsky, 2013). Although new environmental institutions emerged in Peru in the last resource boom cycle due to isomorphism, they now suffer from weak enforcement capacity and, in the eyes of the people, have lost legitimacy and the shared meaning of its mission. Enforcement refers to the degree to which these laws are complied with in practice (Murillo \& Levitsky, 2013). When all relevant actors in the extractive sector in the territory routinely comply with these laws or face a high risk of punishment, then enforcement is high; when this is not the case, enforcement is low. In addition, many scholars have stressed the centrality of the cultural-cognitive elements of institutions, or, as Scott puts it, "the shared conceptions that constitute the nature of social reality and the frames through which meaning is made" (2008, p. 57). Thus, an institution is stronger if it achieves significant "sedimentation of meaning" of its mission. This means that compliance to its rules follows from routines that are taken for granted, because they develop an (otherwise inconceivable) common understanding and cultural frame of their actions and the particular actors associated to them (Scott, 2008).

This chapter argues that two mechanisms are weakening institutional reform. The first mechanism is that isomorphic institutional change does not necessarily dismantle old practices, which undermine enforcement capacity and the sedimentation of a shared meaning of the mission of the institution. Old practices survive the new institutions in informal and embedded practices in the sector, rooted in "the way we do these things" (Scott, 2008, p. 58). They do not threaten the formal stability of institutions (Murillo \& Levitsky, 2013), as they are lawfully in force, but sabotage the enforcement power of new rules and their legitimacy among the public. The chapter shows in the following section how the influence of the industry over the state, mainly over the MINEM, remained an old practice and undermined the regulative (enforcement) and cultural (legitimacy) power of the OEFA.

The persistence of these old practices, in this case of the mining industry, has important consequences regarding the weakening of new institutions to protect the environment in the context of the new extractive industries boom cycle. The analysis seeks to highlight that the deficit of institutions such as the OEFA is not due to the inexorable ambiguities found in the laws themselves or to a 
lack of administrative capacity, but mainly because of "the ability of the actors to avoid the application, in direct violation of the (de facto) rules" (Murillo \& Levitsky, 2013, p. 100). Isomorphic institutional change does not necessarily alter previous power arrangements, which explains the inconsistency or decoupling (Meyer et al., 1997), between the formal processes of rulemaking and those who possess de facto power. In Meyer \& Rowan's (1977) words, the new rules may change their form and acquire an official preponderance, but, as we have noted, they are "myth and ceremony".

The second mechanism is that isomorphic institutional change does not necessarily articulate broad social support around these new rules once created. Many scholars have stressed the important role of professional elites in translating and disseminate new rules (Powell \& Dimaggio, 1991). These professionals are embedded in epistemic (Haas, 1992) and transnational networks of activism (Keck \& Sikkink, 1998). Many times, these professionals gain power by occupying crucial positions in the government. However, the power of these professionals is unstable. Sometimes their opinion can transcend to the media due to their expertise, but they do not articulate political power or social movements to rally in support of the new rules.

In the particular context of Peru, extractive industries have been associated with hundreds of conflicts, which represent close to the $70 \%$ of all social conflicts, according to the Ombudsman's Office. However, these conflicts were glocalized mobilizations (Paredes, 2016). This means that local protests have scaled up into global platforms and communities have reached international alliances to defend their demands. However, at the national level, these conflicts have remained disarticulated (Paredes, 2016). Thus, they open opportunities for institutional change by accentuating crucial institutional agendas, and placing pressures on international actors that strike back on national governments (Keck \& Sikkink, 1998). Nonetheless, once institutional changes occur, and new rules face opposition, there is a lack of articulated social support to avoid the assault of still-powerful actors that can use informal practices to undermine the enforcement and legitimacy of the new institutions.

Table 11.1 summarizes the empirical evidence presented in the chapter. The first four sections explain in chronological order the effects of the first mechanism to weaken the power of OEFA: mission reduction first sapped its enforcement power, then later its sanctioning power, and ultimately damaged the meaning of its mission through divisive accusations that environmental regulation was obstructing investment, which set up a false dilemma between sanctions and incentives. As a result, OEFA ended up with a lack of credibility among communities and with the public in general.

Finally, Section 5 explains how in mechanism 2, local conflicts were important to open opportunities for the expansion of institutions, and how many were even crucial in emphasizing some institutional issues in the global and national agenda. However, there was nonetheless a lack of articulation of a social base to defend the new rules after their creation in a context of significant opposition and power from the industry. 
Table 11.1 The weakening of environmental institutions to protect the environment in Peru

\begin{tabular}{lll}
\hline Mechanisms & Enforcement capacities & Common sense of its mission \\
\hline $\begin{array}{l}\text { 1) New institutions do not } \\
\text { replace old practices: the } \\
\text { influence of the extractive } \\
\text { industry on the public sector }\end{array}$ & $\begin{array}{l}\text { Mission reduction } \\
\text { The weakening of sanction }\end{array}$ & $\begin{array}{l}\text { Distortion of the institution's } \\
\text { objective: "Tramitology" and } \\
\text { the false dilemma between } \\
\text { a sanction and an incentive } \\
\text { approach }\end{array}$ \\
$\begin{array}{ll}\text { 2) Institutional change } \\
\text { without social mobilization }\end{array}$ & $\begin{array}{l}\text { Local conflicts opened opportunities for the expansion of } \\
\text { institutions. } \\
\text { Lack of articulation of a social base to defend the new rules }\end{array}$ \\
\hline
\end{tabular}

Source: Own elaboration

\section{Old practices and the weakening of the OEFA's power}

In order to create the new environmental rules, the government of Alan García formed a commission led by a well-known and recognized environmental professional, José Brack, ${ }^{8}$ which also included 12 other environmental specialists. ${ }^{9}$ Most of them knew each other and had discussed over the years the problems of Peruvian environmental institutions. Some had been extremely critical of the previous cross-sectoral model (Aldana, 2013). A crucial organization that articulated these professionals was a legal NGO, the Peruvian Society of Environmental Law (Sociedad Peruana de Derecho Ambiental, SPDA), which had many ties to other international organizations in the environment field. The leader of SPDA was Manuel Pulgar-Vidal, who had manifested on multiple occasions that the previous institutional system of supervision was inadequate (Pulgar-Vidal, 2008). Thus, the government's call to elaborate the Law of the Ministry of the Environment was a unique opportunity for these professionals to dismantle the previous model and move on to a centralized and more autonomous one.

\section{Narrowing its mission from the beginning}

The National Society of Mining, Petroleum and Energy (Sociedad Nacional de Minería, Petróleo y Energía, SNMPE) and the MINEM together became the main opposition to this commission. They entered into direct conflict with the commission by resisting the application of the new rules to the mining and energy sectors. They agreed with the creation of a Ministry of the Environment but opposed its authority over their sectors. While not able to avoid the application of the new rules entirely, the SNMPE and the MINEM opposition did manage to reduce the power and coherence of the overall system by narrowing the mission of the newly created regulatory agency, the OEFA.

The Brack Commission had proposed the creation of an agency of supervision and control as a specialized technical agency with authority over all sectors. ${ }^{10}$ This agency would have, among other functions, the responsibility for environmental certification, with the execution of environmental 
impact assessments; and environmental audits, carrying out the supervision and enforcement of environmental standards across the sectors. The industry and the MINEM voiced strong disagreements with the Brack Commission over this proposal.

When the commission began its work, there were already rumors that the new environmental authority would not have authority over mining and hydrocarbons. ${ }^{11}$ These rumors were made public with statements from MINEM authorities. Alongside declarations from the Prime Minister that "mining issues would be left to the Supervising Organism for Investments in Energy and Mining (OSINERGMIN)", the Minister of Energy and Mines, Juan Valdivia, openly declared that "the creation of a new agency to protect the environment in the sector of mining and energy within the MINAM would be unnecessary, due to the existence of a similar agency already operating in the MINEM, the OSINER GMIN" (Balbi, 2008).

However, there was a consensus among experts and international representatives that the whole point of the reform was to make the system more autonomous. For Pulgar-Vidal, member of the Brack Commission, creating a new agency without authority over some sectors, in particular the most important, was "nonsense". ${ }^{12}$ Even the newspaper El Comercio (2008), known for its conservative editorial line, produced a report expressing that there was a consensus among professionals and experts on the need for a centralized agency with authority over all sectors: "the new ministry should absorb the supervisory role of the sectors, especially regarding mining, energy projects and other extractive activities".

The OEFA finally achieved authority over all sectors, but in the negotiation process lost half of its proposed functions. With this, the new system of rules lost much of the coherence that the initial proposal had planned. This consisted in a single body that would grant the permits that would then supervise and control that the economic agents comply with the conditions with which those environmental permits were granted. In the negotiation, however, these two important functions ended up separated, when the new agency, the OEFA, lost its authority in granting environmental permits. The MINAM and the OEFA were both created by Legislative Decree 1013, but the OEFA ended up with much less authority than the one initially envisioned by the Brack Commission (Granados, 2016).

Environmental permits and the carrying out of environmental impact assessments remained in the hands of the MINEM until 2015, the year in which all new requests were processed by the National Environmental Certification Service (Servicio Nacional de Certificación Ambiental, SENACE). All unresolved requests before 1995 remained under the authority of the MINEM. SENACE only emerged because of the pressure of international organizations to ensure that the Peruvian State comply with the commitments of the reform. Environmental permits were to be centralized in a single agency, but the MINEM resisted until the end, arguing that the creation of this additional agency was unnecessary, as was the creation of the OEFA. The MINEM's position was that 
"there were already mechanisms that could be reinforced" inside the MINEM (Carlos Aranda, president of the Committee of Environmental Affairs of the SNMPE)..$^{13}$

Thus, in practical terms, SENACE defines the OEFA's scope of authority, as it is SENACE that indicates, by an administrative instrument, what the OEFA must inspect. ${ }^{14}$ In addition, the MINEM achieved during the negotiation that the OSINER GMIN, the control agency within the MINEM, retain the supervision of technical aspects and of the security of the infrastructure of companies (machinery, transport pipelines etc.). The OEFA is responsible for supervising and sanctioning the impact of companies on natural bodies (water, air, soil), according to fixed environmental standards..$^{15}$ However, it cannot control or sanction the infrastructural problems that are the cause of these impacts. For example, the North Peruvian Pipeline had various dangerous spills in the previous years in the Amazon, with serious impacts for indigenous communities. The OEFA can assess the presence of heavy metals in the water and punish PetroPeru for these spills, but cannot take any action regarding the repair or renewal of infrastructure of the pipeline, because this is OSINGERMIN's purview.

To sum up, the formative stage of environmental control was influenced by the new centralized models of environmental management, internationally spread, but also by the opposition of the industry whose influence over the MINEM had not been unsettled. Despite all these limitations, the creation of the OEFA has meant a radical change for Peru, which nonetheless still has a long way to go in fulfilling its promise.

\section{Taking the OEFA's enforcement power}

The industry quickly challenged the new rules following the activation of the OEFA in 2010. An important first step was that the OEFA changed from the system of outsourcing used by OSINGERMIN (hiring external companies and themselves doing desk inspection) to supervisions carried on by its own personnel and with increasing visits to the field. Greater financial capacity due to the establishment of a "Contribution for Regulation" (Aporte por Regulación, APR) in 2014 enhanced the supervision of activities. ${ }^{16}$ The APR established that extractive companies pay a percentage of their profits, not more than $1 \%$, to finance the supervisory work carried out by the OEFA. Although the law allows for a maximum percentage of $1 \%$, the OEFA has only charged a maximum of $0.15 \%$ of the annual sales of each company, after the deduction of several taxes. ${ }^{17}$ The APR constitutes between $70 \%$ and $80 \%$ of the agency's budget.

By 2014, the OEFA's sanctioning capacity became highly visible. The enforcement of environmental standards in the extractive sector started some years ago with the creation of the OSINER GMIN in 2008 (Orihuela \& Paredes, 2017). However, since 2014, the number of sanctions and fines imposed by the OEFA has risen steeply. Autonomy came with transparency in the numbers: sanctions grew from 150 in 2011 to 645 in 2012, and to 1,486 in 2013. In a ranking published by Convoca (Valle \& Castro, 2015) of the companies with the 
most infringements in the extractive sector between 2008 and 2014, the 30 largest offenders in the mining sector paid around $\$ 56$ million in fines, while only three offenders in the hydrocarbons sector paid around $\$ 27$ million in fines.

Pollution generated by these industries was always well known among the public, but never before measured. The industry frequently denied the existence of this contamination, particularly in the mining sector. Since the 2000s, companies tried to reinforce the idea of New Mining, a clean break with the extractive industry's dirty past in the country, and offered a new friendly relationship with the environment and local communities ( $\mathrm{Li}, 2015)$. The discussion of enforcement of environmental sanctions and fines by an official state agency in the media was without precedent in Peru. ${ }^{18}$ The former director of the OEFA, Hugo Gómez, said in an interview: "it was the first time in Peru that an industry as strong as the mining industry complained about excessive environmental control and regulation. ... [W] hat happened is that there was no control whatsoever before". ${ }^{19}$

The industry reacted by pushing the government of Ollanta Humala to reduce the OEFA's authority. On one hand, in June 2014, a group of mining companies decided to sue the OEFA because of the APR payment, as it was the main source of the OEFA's resources for supervision. ${ }^{20}$ The MINEM claimed that ideological positions were emerging to oppose private investment in the name of environmental protection (Ernesto Soto Chávez, advisor to MINEM). ${ }^{21}$ The Judiciary has ratified the APR payment several times since 2015; however, companies have appealed each time. The Constitutional Tribunal, Peru's highest judicial authority, made a final decision in 2019, stating that the OEFA could continue charging the APR. ${ }^{22}$

On the other hand, the industry's opposition to the OEFA's power of enforcement materialized with the promulgation of Law $30230,{ }^{23}$ known as the first paquetazo ambiental. The law restricted the OEFA's sanctioning power for two years. It could only issue exceptional sanctioning procedures and corrective measures. In addition, fines previously issued by the OEFA were reduced by $50 \% .{ }^{24}$ Finally, the approval of the Environmental Quality Standards (Estandares de Calidad Ambiental, ECA) and Maximum Permissible Limits (Límites Máximos Permisivos, LMP), with which fines are determined, would no longer only be the purview of the environmental sector (the MINAM) but also of "each sector involved", for instance the MINEM for mining and hydrocarbons (Araujo et al., 2015). With these measures, the state exempted the mining and hydrocarbons industry from up to $\$ 20$ million in fines for environmental infractions that had been ratified by the courts and even consented to by the companies themselves (Valle \& Castro, 2015).

Figure 11.1 shows the decline in OEFA's enforcement power after the paquetazo ambiental. The industry openly supported these measures. The president of CONFIEP, the National Confederation of Private Business Institutions, Alfonso García Miró, said that regulatory bodies, including the OEFA, were not acting neutrally but were rather unfairly sanctioning companies: "They have changed their attitude and have neglected its role in the market with unbalanced 


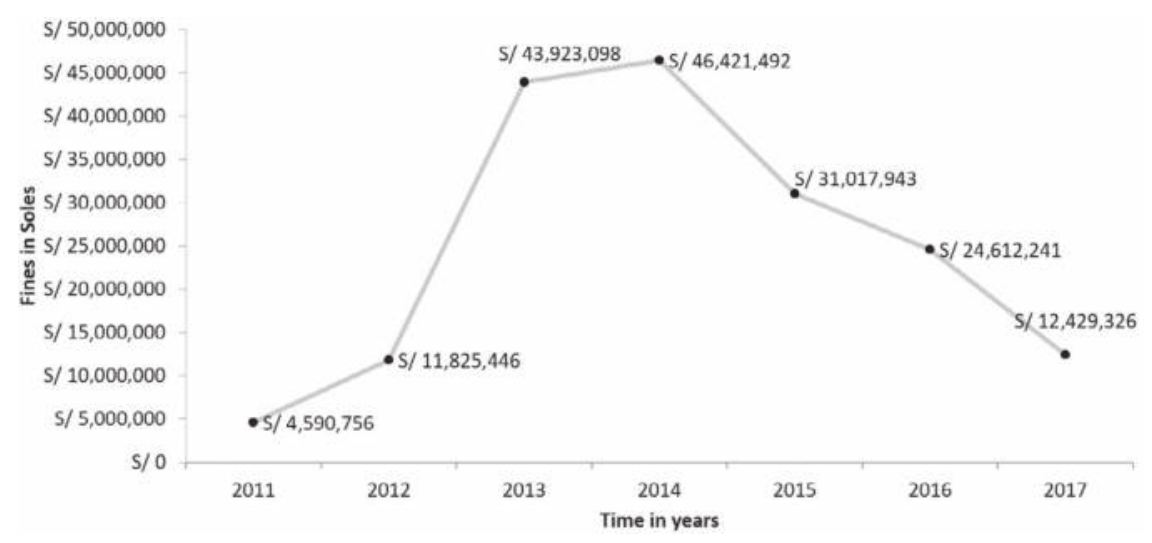

Figure 11.1 Fines collected by the OEFA, 2011-2017

Source: OEFA 2017.

penalties that cause cost overruns for companies". ${ }^{25}$ Furthermore, García Miró pointed out that he agreed with the new law, although he was not satisfied because it was "a shy step". However, at least it made the OEFA "correct its excesses that slow down economic investment". ${ }^{26}$

\section{Distorting the shared meaning of the OEFA's mission}

The opposition of the business associations did not only succeed in weakening the OEFA's enforcement capacity. This also contributed in diminishing the shared meaning of the OEFA's purpose. On the one hand, several declarations were made by business sector representatives in the media in defense of eliminating the red tape (tramitología) that surrounds and hinders private investment in the extractive sector. This has gradually contributed to undermining the original meaning of the institution. In 2012, Alonso García Miró, the aforementioned president of CONFIEP, declared: "there is a large stock of private investment projects paralyzed by administrative issues. There are energy, oil, mining and industrial projects paralyzed by lack of authorizations, permits" (Perú21, 2012).

In response, the state responded with a series of initiatives to finish and make environmental regulation processes more flexible (Durand, 2016). In 2014, Minister Eleodoro Mayorga of the MINEM supported the petition and maintained that new environmental regulation was being prepared in his ministry in order to deal "organically with the red tape and part of the bureaucracy that impedes private investment” (Quispe \& Cárdenas, 2018). These regulations would be the reforms included in Law 30230 and the New Hydrocarbons Law, which would cause, months later, the Cornejo Leaks scandal. ${ }^{27}$ The leaks uncovered the still-blurry frontier between the public and private sectors that 
persists in environmental administration in Peru. The news site Ojo Público ran an independent investigation that revealed a series of conversations between the minister of the MINEM, Eleodoro Mayorga, and of the MINAM, Manuel Pulgar-Vidal, in which they admit that the initiative to modify the Hydrocarbons Law to eliminate the requirement of environmental impact assessments within the sector was drafted by the oil company Karoon. Karoon acted as a consultant at the request of Minister Mayorga, tasked with justifying a favorable law for private oil companies (Mejía, 2014). According to the leaks, Minister Mayorga sustained that "the companies and their technicians are those that can better explain what the operations and their impacts are" (Durand, 2016, p. 66).

Furthermore, interviews with OEFA officials indicate that they sought to adapt to these losses of power. OEFA Board of Directors Resolution 0402014-OEFA/CD changed the environmental control regime from fines to an incentive system. Likewise, OEFA executives built a narrative that highlighted the important of incentives and was critical of fines and to the previous overregulatory nature of the OEFA. Hugo Gómez pointed out that "emphasizing environmental protection, through corrective measures, is consistent with the OEFA's role in contributing to the continuous improvement of environmental performance". ${ }^{28}$

The choice between incentives and fines is a false dilemma, because institutions use both enforcing and promotion mechanisms to be strong (Rueschemeyer, 2009). The result of the paquetazo ambiental was the weakening of the OEFA and the subsequent rapid rise of infractions in the sector. In 2016, the new director of the OEFA declared that Law 30230 did not help to reduce environmental infractions. On the contrary, there were more incentives to be an offender because of the lower cost of incurring in a liability. ${ }^{29}$ In the same report, the OEFA presents alarming data, with the percentages of unpaid fines and regulatory violations increasing from $24 \%$ to $71 \%$ in hydrocarbons and from $10 \%$ to $37 \%$ in mining.

\section{The delicate situation of the OEFA after the paquetazo law}

The mining and hydrocarbons industry's influence has also gradually extended to the OEFA through a series of revolving doors. These are mechanisms through which professionals with long trajectories in the extractive sector occupy high-level positions in the regulatory agency. In 2018, the virtual platform for investigative journalism Convoca presented data describing this movement of high-level employees between the private and public sectors, including in the OEFA (Quispe \& Cárdenas, 2018). For instance, it showed that the OEFA in 2014 hired as coordinator of the Direction of Environmental Supervision in Mining a professional who worked 15 years as a high-level office at the Buenaventura mining company. Buenaventura had an accumulated number of 74 sanctioning processes between 2008 and 2018 (Quispe \& Cárdenas, 2018), and was, according to the same study, one of the main beneficiaries of the environmental paquetazo law in 2014 that exempted the company from a large 
part of its fines. A similar situation was demonstrated for two other supervisors (Quispe \& Cárdenas, 2018).

The extractive sector continued to press for reductions in the enforcement and regulatory power of environmental institutions. On example of this is a bill still in debate to modify the Organic Hydrocarbons Law (Law 26221). ${ }^{30}$ This bill seeks to bring back environmental assessments and supervision from the National System of Environmental Impact Assessment (Servicio de Evaluación de Impacto Ambiental, SEIA) and SENACE to the MINEM and PetroPeru (CooperAcción, 2018). The bill aims to make environmental regulation more flexible and, for instance, gives PetroPeru powers to prepare required environmental baselines (Centro para el Desarrollo del Indígena Amazónico, 2018). Finally, the bill extends oil concessions to up to 80 years, and eliminates hydrocarbons companies' obligation to contribute to the National Environment Fund (Fondo Nacional de Medio Ambiente, FONAM). This fund currently serves to remedy environmental liabilities and sites impacted by this activity.

Since its creation, the OEFA has tried to appeal to the public by employing a host of participatory mechanisms (Paliza, 2017). For instance, it created a Participatory Environmental Monitoring Program and guided visits to Early Environmental Assessments (Evaluación Ambiental Temprana, EAT). The OEFA has also opened decentralized offices in an effort to disseminate its presence nationwide. ${ }^{31}$ However, no effort has been successful in neutralizing the growing harm to its reputation. While this chapter offers a national perspective on the OEFA, a close-up of one of the OEFA's decentralized offices in a mining area, for example in Espinar, Cusco, shows a process of discredit among the population. The Espinar office was announced with great enthusiasm by civil society organizations in Espinar, and local communities were highly optimistic that their presence would guarantee better and more transparent information regarding the quality of the environment (CooperAcción, 2015). However, four years after its creation in 2015, people believe the office serves no purpose. After the emergence of serious controversies regarding pollution in the area, the OEFA has been unable to offer solutions or better information. The following testimony registers the disappointment in the work done so far by the OEFA in Espinar:

About the OEFA, they tell us that the "OEFA is the mine's right hand". Likewise, for them, the "ANA (National Authority of Water), the OEFA and the company live together". The distrust towards these institutions is based, mainly, on the lack of support and attention that they receive regarding their claims of pollution: If you put forward a complaint, they tell you nothing can be done.

(Espinar, June 29, 2019)

A crucial problem is that the OEFA has insufficient technical equipment in its laboratories, and lacks modern technical support to systematize and integrate data with other authorities, and thus in certifying the validity of its results. ${ }^{32}$ 
The results of a survey conducted in 2017 in selected areas by the OEFA are therefore not all that surprising. Only $21 \%$ of those consulted knew the OEFA, and of those only $19 \%$ had any knowledge of the existence of decentralized offices. Moreover, among those who did have knowledge of the OEFA, an overwhelming $72 \%$ considered that it had not improved the protection of the environment since its creation (OEFA, 2020). The OEFA's situation is currently delicate after all these years of modifications.

\section{Isomorphic institutional changes and the lack of social support}

The isomorphic institutional change process has failed to articulate a social base with a common narrative in defense of autonomous and more effective environmental institutions. In Peru, economic growth generated by the expansion of extractive industries went hand in hand with a steep increase in socio-environmental conflicts (Paredes \& de la Puente, 2014), as shown in Figure 11.2.

Many researchers coincide in associating these conflicts with distribution budget problems and environmental unrest associated with extractive activity

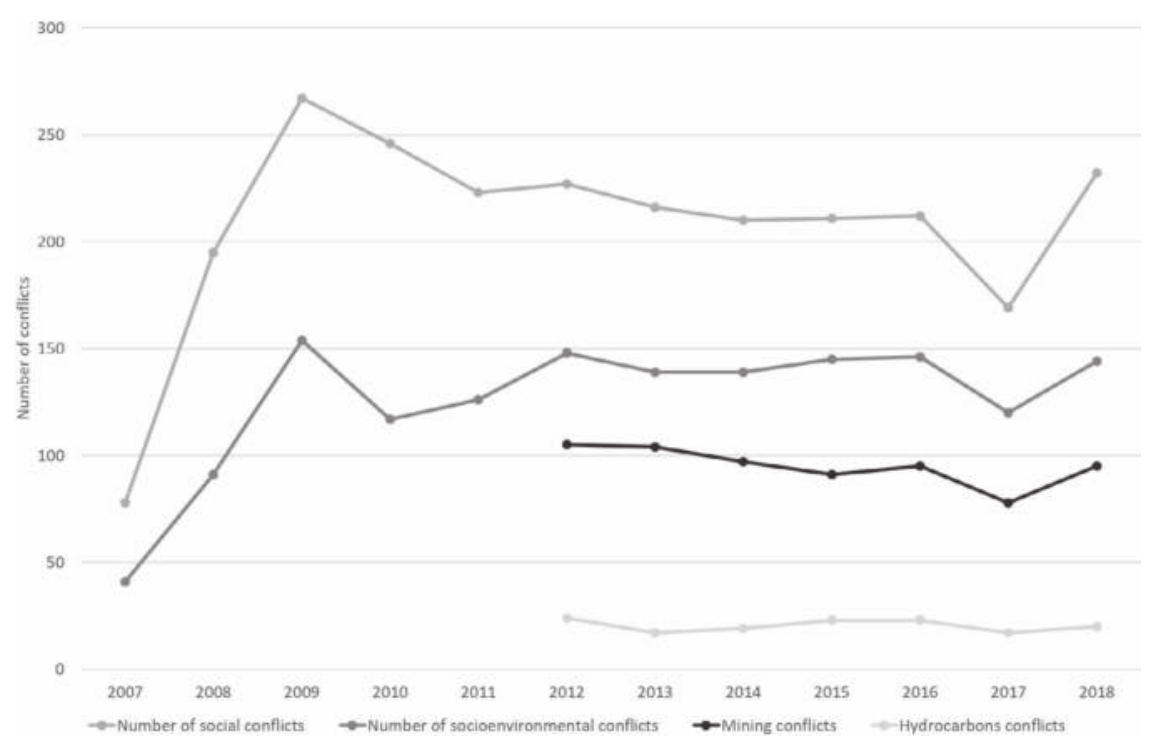

Figure 11.2 Conflicts in Peru (environmental, mining and hydrocarbons, 2007-2018) Source: Paredes (2019) based on the Ombudsman's Office annual reports (2007-2017). 
(Orihuela \& Paredes, 2017). One of the main demands of these conflicts was the need for a transparent institutional reform of environmental protections. Some of these socio-environmental conflicts were crucial in putting the modification of environmental institutions on the national agenda.

The massive social mobilization in Tambogrande, Piura, in rejection of a mining project that threatened the agricultural character of the area, was one such conflict. This mobilization in the Tambogrande valley had important consequences in the enforcement of environmental regulation policy, mainly in the modification and improvement of the environmental impact assessments (de Echave, 2013). Similarly, the opposition to the Conga mining project in Cajamarca and the Tía María mining project in Arequipa raised questions about environmental impact assessments, and both opened an important political space for the creation of SENACE (CooperAcción, 2012). However, none of these social mobilizations produced sustained articulated movements at the regional or national level that could support the consolidation of new environmental institutions once they are in place. In fact, no important social base emerged to defend the OEFA against the successive efforts to weaken it. Conflicts in Peru are like an archipelago of mobilizations. Each island in the archipelago is individually connected to transnational actors, mining companies, the central state and networks of transnational activism, while being very much disarticulated at the national level (Paredes, 2016).

The many scandals surrounding the influence of the industry over the public sector was followed by very little mobilization, limited to media networks, NGOs (such as Red Muqui, Servindi etc.) and independent journalism (Ojo Público, Convoca). No large mobilization followed the different instances in which OEFA was undermined and did not use its power. Regarding the controversy around the APR, the government has opted for silence. With the exception of the OEFA's current president, no state representative, neither from the MINAM nor from the Ministry of Justice, has made declarations in defense of the OEFA (Ruiz, 2017). Some NGOs have again initiated internet campaigns, such as the Red Muqui (2019) or SPDA (2019), but there has been no articulated support or activism.

\section{Conclusion}

In this chapter, we have tried to explain why isomorphic institutional changes in environmental control in Peru produced weak institutions. This chapter argues that the new rules regarding environmental control are a positive expansion in the governance of extractive industries in Peru. However, the chapter seeks to problematize their effectiveness in practice and implementation.

The main problem that arises regarding isomorphic institutional change is that it does not undermine the political power existing underneath the old rules. Old power arrangements survive embedded in informal practices that persist and undermine new institutions. The alliance between the extractive industry and the MINEM has led to the weakening of the enforcement capacity of the 
OEFA throughout the past years. In addition, this alliance serves to shape the public discussion in a way that distorts the shared meaning of the mission of the new institutions and their legitimacy.

Another important part of the argument is that this type of isomorphic change in Peru has not required the articulation of social bases at the national level than can defend the new rules. Institutional reform articulates groups of elite entrepreneurial professionals, who, throughout the persistent weakening of the institutions, can seldom do very much to defend their own creation. Mobilizations are locally situated and with a lot of international resonance, but there has been significant articulation into a national social movement whose objective would be the strengthening of the environment institutions.

Thus, this chapter highlights the role of social mobilization in institutional change as crucial in a context where there is a strong opposition from part of the industry to build strong environmental governance. However, isomorphic institutional change does not seem to trigger that mobilization. It remains important to analyze more deeply the role that territorial and ecological conflicts and their capacity to accumulate and articulate play in guaranteeing better national rules.

\section{Notes}

1 https://peru21.pe/economia/defensoria-hay-9-000-peruanos-expuestos-contaminacion-industrias-extractivas-nndc-429179-noticia/

2 Legislative Decree 1013, May 2008.

3 Peruvian Central Reserve Bank (BCRP) statistics, reviewed in 2019.

4 In the sense of Mahoney and Thelen (2009).

5 Supreme Decree 016-93-EM.

6 Several of these advances were made in the context of the Mineral Resources Sector of Peru Reform Project-Proyecto de Reforma del Sector de Recursos Minerales del Perú (PERCAN).

7 https://elcomercio.pe/edicionimpresa/html/2007-1028/el_sindrome_del_perro_del_ hort.html

8 Ministerial Resolution 025-2008-PCM, January 30, 2008

9 The Brack Commission was constituted by Antonio José Brack Egg, Carlos Aranda Arce, Manuel Ernesto Bernales Alvarado, Richard Bustamante Morote, Luis Campos Baca, Fabiola Capurro Villarán, Mariano Castro Sánchez Moreno, Jaime Delgado Zegarra, Elsa Galarza Contreras, Luis Gomero Osorio, Ruth Aubert Cárdenas and Patricia Fernández-Dávila.

10 Multisectoral Technical Commission established by Ministerial Resolution 025-2008-PCM.

11 https://elcomercio.pe/edicionimpresa/Html/2008-01-28/es-desproposito-queministerio-medio-ambiente-no-vea-mineria.html

12 https://elcomercio.pe/edicionimpresa/Html/2008-01-28/es-desproposito-queministerio-medio-ambiente-no-vea-mineria.html

13 https://gestion.pe/peru/politica/snmpe-creacion-senace-responde-decision-politicanecesidades-tecnicas-sector-minero- 25253

14 Environmental Adaptation and Management Program (Programa de Adecuación y Manejo Ambiental-PAMA)

15 Environmental Quality Standards (ECA's) and Maximum Permissible Limits (LMP) established by the MINAM 


\section{Maritza Paredes and Lorena Figueroa}

16 Supreme Decree 130-2013-PCM, that established, for 2014 and 2015, that big- and medium-scale mining companies would contribute $0.15 \%$ of annual turnover to the functioning of the OEFA; and for 2016, 0.13\%. For 2017, 2018 and 2019, Supreme Decree N 097-2016-PCM stated that the APR would be $0.11 \%$.

17 www.muqui.org/comunicaciones/noticias/item/146-oefa-explica-por-que-el-aportepor-regulacion-es-mejor-para-la-mineria-y-el-peru

18 http://utero.pe/2015/01/30/exclusivo-las-mineras-mas-multadas-por-contaminar-sonlas-que-quieren-debilitar-al-oefa/

19 Interview with Hugo Gómez Apac, former CEO of the OEFA (2015).

20 On October 30, 2014, according to the OEFA Environmental Oversight Court, 32 of the 36 mining companies against the Contribution for Regulation (APR) had committed at least one environmental infraction. By the same date, according to the OEFA's Registry of Administrative Acts, 363 companies (mostly from the mining and hydrocarbons sector) had breached and exceeded the environmental standards stipulated by the OEFA, especially regarding the Maximum Permissible Limits.

21 https://gestion.pe/opinion/regulacion-ambiental-2-0-67098

22 www.oefa.gob.pe/noticias-institucionales/el-tribunal-constitucional-valida-la-legalidad-del-aporte-por-regulacion-que-financia-la-fiscalizacion-ambiental-del-oefa-en-elsector-minero

23 Article 19 of Law 30230 prevents the OEFA from imposing fines in the first instance for violations of the regulations.

24 Board of Directors Resolution 041-2015-OEFA/CD (September 24, 2015).

25 https://gestion.pe/opinion/regulacion-ambiental-2-0-67098

26 https://peru21.pe/economia/confiep-paquete-economico-castilla-quedadocorto-167214

27 "Cornejo Leaks" was the name given to the 2014 political scandal in which the personal mail of former Prime Minister of Ollanta Humala, René Cornejo, was leaked, revealing differences and arrangements among the members of the Cabinet, as well as acquaintances between businesspersons and executive authorities. Peruvian hackers Anonymous Peru and Lulz Security Perú were behind the leak.

28 https://elcomercio.pe/opinion/colaboradores/oefa-camino-trazado-hugo-gomezapac-334136

29 Interview with Tessy Torres. See: http://convoca.pe/agenda-propia/oefa-reconoceimpacto-nocivo-de-la-ley-del-paquetazo-ambiental

30 www.actualidadambiental.pe/propuesta-para-modificar-ley-de-hidrocarburos-debilitaria-la-institucionalidad-ambiental/

31 Board of Directors Resolution 018-2018-OEFA-CD

32 www.minam.gob.pe/oficina-general-de-planeamiento-y-presupuesto/wp-content/ uploads/sites/139/2019/04/Formato-04-Apublicaci\%C3\%B3n.pdf

\section{References}

Aldana, M. I. (2013). Desafíos de la facultad de tipificación de infracciones ambientales a cargo del OEFA. In Organismo de Evaluación y Fiscalización Ambiental (Ed.), El nuevo enfoque de la fiscalización ambiental (pp. 329-354). OEFA.

Araujo, J. P., Bengoa, C., Calle, I., Capella, J. L., Delgado, D., Mora, C., \& Peña, P. (2015). Fiscalización Ambiental. Recomendaciones para un fortalecimiento integral. SPDA. https://spda. org.pe/?wpfb_dl=726

Balbi, M. (2008, January 28). Es un despropósito que el ministerio del medio ambiente no vea la minería. Entrevista a Manuel Pulgar Vidal. El Comercio. https://elcomercio.pe/ edicionimpresa/Html/2008-01-28/es-desproposito-que-ministerio-medio-ambienteno-vea-mineria.html 
Centro para el Desarrollo del Indígena Amazónico-CEDIA. (2018, September 13). Pronunciamiento: Propuesta de nueva Ley Orgánica de Hidrocarburos pone en riesgo la institucionalidad ambiental $y$ derechos indígenas. https://cedia.org.pe/pronunciamiento-propuesta-de-nuevaley-organica-de-hidrocarburos-pone-en-riesgo-la-institucionalidad-ambiental-yderechos-indigenas/

Charpentier, S., \& Hidalgo, J. (1999). Políticas ambientales en el Perú. AGENDA.

CooperAcción. (2012). Actualidad Minera del Perú. Newsletter 231. CooperAcción. https:// cooperaccion.org.pe/wp-content/uploads/2018/09/Boletin-AMP-setiembre-2018.pdf

CooperAcción. (2015). OEFA abrirá una oficina en Espinar. https://cooperaccion.org.pe/ oefa-abrira-una-oficina-en-espinar/

CooperAcción. (2018, October 1). ¿Cuál es el estado de la Ley de Hidrocarburos? https://cooperaccion.org.pe/cual-es-el-estado-de-la-ley-de-hidrocarburos/

Decreto Legislativo N¹013. (2008, May 23). Decreto legislativo que aprueba la ley de creación, organización y funciones del ministerio del ambiente. El Peruano.

Decreto Supremo N016-93-EM. (1993, May 1). Reglamento para la protección ambiental en la actividad minero-metalúrgica. El Peruano.

De Echave, J. (2013). Conflictos sociales: Entre la teoría del complot y los esfuerzos parciales. Revista Ideele, 226. https://revistaideele.com/ideele/content/ conflictos-sociales-entre-la-teorí-del-complot-y-los-esfuerzos-parciales

DiMaggio, P. J., \& Powell, W. W. (1983). The iron cage revisited: Institutional isomorphism and collective rationality in organizational fields. American Sociological Review, 48(2), 147-160. https://doi.org/10.2307/2095101

Durand, F. (2016). Cuando el poder extractivo captura el Estado. Lobbies, puertas giratorias y paquetazo ambiental en Perú. Oxfam. ISBN: 978-612-46622-4-9

El Comercio. (2008, January 20). Informe Ministerio del Ambiente. Hay más de 90 normas ambientales que esperan hace años ser aprobadas.

Granados, A. (2016). La construcción de la fiscalización ambiental en un contexto adverso de boom de recursos naturales: el caso del OEFA [Bachelor's thesis, Pontificia Universidad Católica del Perú]. PUCP Repositorio de Tesis. http://tesis.pucp.edu.pe/repositorio/ handle/20.500.12404/7972

Haas, P. M. (1992). Introduction: Epistemic communities and international policy coordination. International Organization, 46(1), 1-35. https://doi.org/10.1017/s0020818300001442

Keck, M., \& Sikkink, K. (1998). Activism beyond borders: Advocacy networks in international politics. Cornell University Press.

Lanegra, I. (2015). Cambios y continuidades en la institucionalidad ambiental peruana. A 20 años de la creación del consejo nacional del ambiente. Revista de Derecho Administrativo, 15, 21-27. http://revistas.pucp.edu.pe/index.php/derechoadministrativo/article/view/15168/15658

Lanegra, I. (2019). Avances en el desempeño ambiental del Perú. Actualización de la Evaluación de Desempeño Ambiental y análisis de la implementación de recomendaciones seleccionadas, con énfasis en el sector minero. Unpublished Manuscript.

Lanegra, I., \& Hurtado, V. (2013). Estado, recursos naturales y política ambiental: Notas para el caso peruano. Politai: Revista de Ciencia Política, 4(6), 17-31. http://revistas.pucp.edu. pe/index.php/politai/article/view/14111

Larsen, P. B. (2010). Ministerio del Ambiente peruano: Gobernanza e institucionalidad verde. In Centro de Estudios y Promoción del Desarrollo (Eds.), Perú Hoy. Centralismo y concentración (pp. 89-110). DESCO. www.desco.org.pe/ centralismo-y-concentracion-serie-peru-hoy-no18-diciembre-2010

León, A. (2019). La Fiscalización de papel: Los pormenores de un largo y poco exitoso caso de fiscalización ambiental en la Comunidad de San Pedro. Pontificia Universidad Católica del Perú. 
Li, F. (2015). Unearthing conflict: Corporate mining, activism and expertise in Peru. Duke University Press

Mahoney, J., \& Thelen, K. (Eds.). (2009). Explaining institutional change: Ambiguity, agency, and power. Cambridge University Press. https://doi.org/10.1017/CBO9780511806414

Mejía, H. (2014, August 30). Petrolera Karoon elaboró el sustento del reglamento que quiere eliminar los EIA. LaMula.pe. https://lamula.pe/2014/08/12/petrolera-karoon-elaboro-el-sustento-del-reglamento-que-quiere-eliminar-los-eia/ hansmejiaguerrero/

Meyer, F., Frank, J. F., Hironaka, A., Schoefer, E., \& Tuma, N. (1997). The structuring of a world environmental regime, 1870-1990. International Organization, 51(4), 623-651. https://doi.org/10.1162/002081897550474

Meyer, J. W., \& Rowan, B. (1977). Institutionalized organizations: Formal structure as myth and ceremony. American Journal of Sociology, 83(2), 340-363. https://doi. org $/ 10.1086 / 226550$

Murillo, M. V., \& Levitsky, S. (2013). Lessons from Latin America: Building institutions on weak foundations. Journal of Democracy, 24(2), 93-107. https://doi.org/10.1353/ jod.2013.0031

North, D. C. (1990). Institutions, institutional change and economic performance. Cambridge University Press. https://doi.org/10.1017/CBO9780511808678

Observatorio de Conflictos Mineros en el Perú-OCM. (2017). $21^{\circ}$ Observatorio de conflictos mineros en el Perú. Reporte segundo semestre 2017. OCM, CooperAccion, Fedepaz, Grufides. http://grufides.org/sites/default/files//documentos/reportes_semestrales/RevistaInforme-de-Conflictos-Mineros-VI-2.pdf

Ojo Público. (2019, June 5). Amazonía en la encrucijada. https://ojo-publico.com/1226/ amazonia-en-la-encrucijada

Organismo de Evaluación y Fiscalización Ambiental-OEFA. (2018). Plan estratégico institucional 2019-2022. OEFA, Ministerio del Ambiente Perú. www.oefa.gob. pe/?wpfb_dl=33954

Organismo de Evaluación y Fiscalización Ambiental-OEFA. (2020). Informe de Resultados de la Encuesta de Percepción de la Fiscalización Ambiental en Zonas de Conflictividad Socioambiental Priorizadas por el OEFA. en el 2017. Lima, OEFA. https://pifa.oefa. gob.pe/Informes/Informe_de_la_encuesta_de_percepción_en_zonas_de_conflictividad_ socioambiental_2017.pdf

Orihuela, J. C. (2014). Converging divergence: The diffusion of the green state in Latin America. Studies in Comparative International Development, 49, 242-265. https://doi. org/10.1007/s12116-013-9147-6

Orihuela, J.C., \& Granados, A. (2021). Institucionalidad ambiental minera: entre el discurso legal y las prácticas de gobierno. In G. Damonte, B. Göbel, M. Paredes, B. Schorr \& G. Castillo (Eds.), ¿Una oportunidad perdida? Boom extractivo y cambios institucionales en el Perú (pp. 157-188). Fondo Editorial de la Pontificia Universidad Católica del Perú.

Orihuela, J. C., \& Paredes, M. (2017). Fragmented layering: Building a green state for mining in Peru. In E. Dargent, J. Orihuela, M. Paredes, \& M. Ulfe (Eds.), Resource booms and institutional pathways. The case of the extractive industry in Peru (pp. 97-118). Palgrave Macmillan. https://doi.org/10.1007/978-3-319-53532-6_4

Paliza, G. (2017). Los mecanismos de participación ciudadana en la scalización ambiental. Foro Jurídico, 93-109. http://revistas.pucp.edu.pe/index.php/forojuridico/article/ view/19864/19905

Paredes, M. (2016). The glocalization of mining conflict: Cases from Peru. Extractive Industries and Society, 3(4), 1046-1057. https://doi.org/10.1016/j.exis.2016.08.007 
Paredes, M. (2019). Conflictos mineros en el Perú: Entre la protesta y la negociación. Debates en sociología, 45, 5-32.

Paredes, M., \& de la Puente, L. (2014). Protestas y negociaciones socio-ambientales. El caso de las industrias extractivas. In G. Damonte \& G. Vila (Eds.), Agenda de Investigación en Temas Socioambientales en el Perú: Una aproximación desde las ciencias sociales (pp. 75-106). CISEPA-PUCP. http://repositorio.pucp.edu.pe/index/handle/123456789/131399

Perú 21. (2012, January 30). Hay stock de inversión paralizado. https://peru21.pe/voces/ hay-stock-inversion-paralizado-13913-noticia/

Perú 21. (2014, June 24). Confiep: 'Paquete económico de Castilla ha quedado corto'. https://peru21. pe/economia/confiep-paquete-economico-castilla-quedado-corto-167214-noticia/

Powell, W. W., \& DiMaggio, P. J. (1991). The new institutionalism in organizational analysis. University of Chicago Press. https://doi.org/10.7208/chicago/9780226185941.001.0001

Pulgar-Vidal, M. (2008). Ministerio del ambiente: Un largo proceso de construcción de la institucionalidad ambiental en el Perú. Themis: Revista de Derecho, 56, 87-99. http:// revistas.pucp.edu.pe/index.php/themis/article/view/9178

Quispe, A., \& Cárdenas, J. (2018, November 19). Así opera la puerta giratoria de la supervisión ambiental para grandes mineras infractoras. Convoca. http://convoca.pe/investigacion/ asi-opera-la-puerta-giratoria-de-la-supervision-ambiental-para-grandes-mineras

Red Muqui. (2018, October 29). Ministro de energía y minas laboró 22 años para empresas sancionadas por faltas ambientales. https://muqui.org/noticias/muqui-informa/ministrode-energia-y-minas-laboro-22-anos-para-empresas-sancionadas-por-faltas-ambientales/

Red Muqui. (2019, May 13). Pronunciamiento Red Muqui: Empresas buscan dejar sin fiscalización la actividad minera. https://muqui.org/noticias/muqui-informa/pronunciamiento-redmuqui-empresas-buscan-dejar-sin-fiscalizacion-la-actividad-minera/

Resolución Ministerial N 025-2008-PCM. (2008). El Peruano.

Rueschemeyer, D. (2009). Usable theory. Analytic tools for social and political research. Princeton University Press. https://doi.org/10.1515/9781400830671-003

Ruiz, J. C. (2017, July 2). Sentencia del Tribunal Constitucional liquidaría al OEFA y a la fiscalización ambiental en el Perú. LaMula,pe. https://juancruizm.lamula.pe/2017/07/02/ escandalosa-sentencia-del-tc-liquidaria-al-oefa-y-la-fiscalizacion-ambiental-en-el-peru/ juancruizm/

Scott, W. R. (2008). Institutions and organizations: Ideas and interests. SAGE.

SPDA. (2019, May 16). Puntos clave para entender el Aporte por Regulación del OEFA. https:// spda.org.pe/wpfb-file/aporte_por_regulacion-pdf/

Tarrow, S. (1998). Power in movement. Social movements and contentious politics. Cambridge University Press. https://doi.org/10.1017/cbo9780511813245

Valle, E., \& Castro, A. (2015). Los S/.30 millones que no cobró el gobierno en multas mineras. Convoca. https://convoca.pe/investigacion/los-s-30-millones-que-no-cobro-el-gobiernoen-multas-mineras

World Bank. (2007). Republic of Peru. Environmental sustainability: A key to poverty reduction in Peru. World Bank. http://hdl.handle.net/10986/7761 


\title{
12 How to institutionalize sustainability?
}

\author{
Analyzing the enforcement of \\ reparación integral and environmental \\ law in the hydrocarbon sector in \\ Ecuador
}

\author{
Teresa Bornschlegl
}

\section{Introduction}

Andean countries have long based their economies on the export of their natural resources. Nevertheless, the income generated through the rents from resource extraction has historically not translated into the improvement of the life quality and well-being for their wider population. On the contrary, natural resource extraction in the Andean countries went along with significant ecological degradation, violent conflicts, high poverty rates, social inequalities, and the dispossession of local communities. Historically, only a narrow group of elites has benefited from resource rents. Academic and policy literature commonly explain the reasons for this with a phenomenon called the resource curse, "the perverse effects of a country's natural resource wealth on its economic, social, or political well-being" (Ross, 2015, p. 240). Countries that depend on resource extraction lack the institutions necessary to avoid such adverse effects. The building of such institutions is hindered because "[r]esource cursed governments tend to manage natural resources opportunistically rather than strategically. Resource depletion, therefore, tends not to serve the public interest and instead consolidates wealth among a very narrow class of bureaucrats and managers" (Sovacool, 2010, p. 229). Resource-cursed countries are thus stuck in a vicious cycle: building public institutions that would put a check on elites in power would need to rely on precisely those public institutions that were previously built to serve primarily the interests of those same elites.

Two developments at the onset of the 21st century gave a new stimulus to the question of whether natural resource extraction can help countries to transition toward a more socially and ecologically just economy-a post-extractivist economy that has overcome the adverse effects of the resource curse. First, an increase in global prices for raw materials led to a new resource boom from early 2000 onward to approximately 2014. Secondly, some countries in Latin America that experienced a Left Turn sought to establish a post-neoliberal development model in which a strong state would end the social and environmental 
problems that the neoliberal development model had caused. They oriented this post-neoliberal development model around the slogan extracting for escaping extractivism, which entailed the (re)-nationalization of natural resources to invest the revenues gained in welfare programs, poverty reduction, education, health, economic diversification, and environmental protection. Accordingly, these progressive governments established several institutional innovations in governing the extractive sector that would guarantee a more socially and ecologically just distribution of the benefits and costs of resource extraction. These institutional innovations were often pushed for by social, environmental, and indigenous movements and aimed at solving the problems typically associated with resource extraction, and thus at escaping the resource curse. Designed to prevent and fully repair environmental and social damages, these institutional innovations were meant to contribute as a first step to a transition toward a post-extractivist economy.

However, the initial optimism that these progressive governments could help advance real transformation toward socially and ecologically more just economies soon vanished. The expansion of extraction led to even more dependence on resource extraction, socio-ecological conflicts, and dispossession of communal lands; corruption scandals surfaced, and falling global prices for raw materials diminished the capacity of government expenditures. Scholars have examined why the problems associated with the resource curse led, once more, to adverse outcomes, concentrating their analysis on social and economic policies. There is comparatively little analysis, however, on the institutional innovations in the environmental realm. How did they fare during the boom-and-bust cycle? Did they deliver to some extent what they promised or not? What constraints did they face, and how to explain these constraints?

This chapter explores these questions, taking Ecuador as a case study. Ecuador's Constitution Montecristi was adopted in 2008 and is one of the most famous examples of such institutional innovation, as it was the first country to integrate the Rights of Nature as a constitutional provision. This chapter asks to what extent this institutional innovation provided for better enforcement of environmental laws in the hydrocarbon sector. Specifically, it examines the Program of Environmental and Social Reparation (Programa de Reparación Ambiental y Social, PRAS) at the Ecuadorian Ministry of Environment and its enforcement of reparación integral (integral reparation), a concept derived from the Constitution Montecristi. How did PRAS perform? To what extent could state officials working at PRAS enforce the concept of reparación integral in the hydrocarbon sector? What were the most critical constraints that they encountered? This chapter answers these questions through an institutional ethnography of PRAS - following the argument that the complexity of institutional dynamics in the context of resource extraction demands a more qualitative and fine-grained approach than that provided by most resource curse research (Gilberthorpe \& Papyrakis, 2015; Gilberthorpe \& Rajak, 2016; Peters, 2016; Dargent et al., 2017; Bornschlegl, 2018). This chapter draws on qualitative and quantitative data collected during fieldwork in Ecuador over the years 
2013-2018. Quantitative data comprise a database provided by the Ministry of Environment on recorded sources of contamination and the state of the cleanup until the year 2018. Qualitative data comprise 103 interviews with representatives at different entities at national and sub-national levels as well as official documents. Interviews were carried with, for instance, representatives at the Ministry of Environment, the Ombudsman, the Comptroller General, the National Assembly, environmental departments at the provincial government, the secretary of water, the regulatory agency of water, environmental consultancies, laboratories, oil companies, local communities, NGOs, indigenous organizations, ecological and environmental scientists, petroleum engineers, and environmental lawyers. Official documents include the project reports of the three different cleanup projects, Proyecto: Eliminación de Piscinas contaminadas y limpieza de derrames en el Distrito Amazónico (PEPDA) (Petroproducción, 2008), Plan de Restauración Integral de Pasivos Ambientales en el Distrito Amazónico (PRIPA) (Petroecuador EP, 2012), and Amazonía Viva (Petroamazonas EP, 2013), of the public oil company, as well as methodological guidelines from PRAS (PRAS, 2015).

The chapter proceeds as follows: The first section presents the conceptual framework of the relationship between resource extraction, institutions, and the Left Turn. The second section describes the empirical results from the case study examining the enforcement of reparación integral, and the last section draws the main conclusions and reflects on the importance of building a specific type of institutions, namely progressive public institutions, and equipping them with sufficient, capacity, autonomy, and executive power in a sustainable way.

\section{The resource boom and institutions: the Left Turn}

The insight that the existence of functioning institutions is a necessary condition for escaping the resource curse has become a staple in research on resource extraction and the resource curse (Papyrakis, 2017). Of particular importance for avoiding the resource curse are institutions that guarantee a socially and ecologically just distribution of the benefits and costs of resource extraction. However, institutional frameworks (or the absence thereof) in resource-rich countries tend to be a reflection of the interests of those in power and the deals they make (Poteete, 2009; Bebbington et al., 2018). That is, resource-rich countries are stuck in a vicious cycle: building institutions that guarantee a socially and ecologically just distribution of the benefits and costs of extraction would require that such institutions had already been built.

The resource boom at the onset of the 21st century re-opened the question as to whether that vicious cycle could ever be overcome (Dargent et al., 2017; Addison \& Roe, 2018). Especially the governments that were part of the Left Turn in Latin America received much attention in that renewed debate. Not only did these self-defined progressive governments seek to install a whole range of institutional innovations aimed at guaranteeing a socially and ecologically just distribution of the benefits and costs of resource extraction, but they also promised to 
re-invest extractive revenues in the implementation of these institutional innovations (Burchardt \& Dietz, 2014; Burchardt et al. 2016; Broad \& Fischer-Mackey, 2017). These institutional innovations were also unique in the sense they resulted from indigenous, environmental, and social movements that had pushed for them over decades. Ecuador's Constitution Montecristi 2008 and the constitutional enshrinement of the Rights of Nature (Gudynas, 2011, 2013) counts as an example for such institutional innovations. The fact that these institutional innovations resulted from decades of mobilization of social movements also provided input to the debate on the relationship between state institutions and social change. The question became: "what type of institutions can give durability to the achievements of social movements, that, without any type of institutionalization, without any form of fixation in time, would simply vanish, as had happened many times before" (Lang \& Brand, 2015, p. 24, author's translation).

At first, the post-neoliberal development model combined with the resource boom led to an improvement in social and economic indicators, a decrease in poverty and extreme poverty, and better access to social services of the wider population. However, soon enough, it became clear that the government administrations did not advance a transition toward a more socially and ecologically just economy as the movements who had helped it to power had wanted (Cori \& Monni, 2014; de Castro et al., 2016). That is, the progressive governments failed at re-investing the extractive revenues in economic diversification, and at visibly improving the quality or quantity of employment (Gudynas, 2010, 2013; Brand et al., 2016). The progressive governments did not bring about an agrarian reform that would improve the distribution of land nor a tax reform that would make the wealthy part of the population pay their share (Burchardt et al., 2016; Veltmeyer \& Petras, 2014, 2019). The extractive frontier expanded in a way that de-industrialized the economy, increased socio-ecological conflicts, deepened ecological degradation, and further dispossessed local communities (Andreucci \& Radhuber, 2017; Villalba-Eguiluz \& Etxano, 2017; Lu et al., 2017; Svampa, 2017, 2019). Social relations remained ordered along the lines of patriarchy, classism, colonialism, just as in neoliberal times - a social transformation that would have changed the distribution of the privileges of those in power did not occur (Acosta \& Iturralde, 2013; Bull \& Aguilar-Støen, 2015; Bebbington et al., 2018). Why did the post-neoliberal development model combined with the resource boom fail to escape the resource curse? Some scholars argue that this would be so because "entrenched elites have hindered structural transformations towards an environmental governance that ensures more sustainable and equitable production" (Bull \& Aguilar-Støen, 2016, p. 139). Or, as Ospina Peralta (2012, p. 129) put it:

Why did it turn out so difficult for them [the progressive governments] to achieve any sowing after having reaped so many dollars? For the simple reason that those economic activities not only leave money in the pockets but also knit structures of power. 


\section{Teresa Bornschlegl}

While scholars provided useful insights regarding the question of why postneoliberal governments and their economic strategies failed, less disaggregated, empirically based analysis exists on what precisely happened with the institutional innovations in the environmental realm. What were the exact processes that kept those institutional innovations from developing more force? This chapter focuses on the program of Social and Environmental Reparation (PRAS) at the Ecuadorian Ministry of Environment, and its implementation of reparación integral (integral reparation) in the hydrocarbon sector. The concept of reparación integral derived directly from the Constitution Montecristi and meant to translate the constitutional provisions for environmental and social rights into public policy and practice. A reparación integral did not mean just remediating environmental damages, but to restitute the social and environmental rights and dignity of affected communities and nature and to guarantee the non-repetition of the damage. Reparación integral is thus akin of the mechanism of reparations for victims of human right violations as conceptualized by the United Nations, which comprises a guarantee for restitution, compensation, rehabilitation, satisfaction, and non-repetition to the victims of the violation (UN General Assembly, 2005). It is fair to say that one can consider the constitutional premise that one should repair damages integrally as a progressive innovation with the potential to advance pathways toward a socially and ecologically more just economy:

Here are some rough ideas still based in the field of conventional economics, from which one would need to construct the post-extractivist transition as a base for a new economy, one that we could define as an economy of Buen Vivir. To achieve this, it is necessary to deploy strategies that allow transitioning while still extracting-but less and less - the natural resources that carry the resource curse with them. . . The task is not to simply extract more natural resources for obtaining income that helps to overcome extractivism. One instead needs to optimize extraction without causing further environmental and social damage, including trying to repair and even restore the damage caused.

(Acosta, 2017, p. 10, author's translation \& emphasis)

The subsequent section presents empirical results on the performance and limitations of reparación integral in environmental law enforcement.

\section{Limits to reparación integral and environmental law enforcement}

\section{Reparación integral and the history of oil extraction}

The Ecuadorian environmental regulation defines reparación integral as:

A set of actions, processes, and measures, which . . . tend to reverse environmental and social damages and liabilities, by restoring quality, dynamics, 
ecological balance, cycles vital, structure, functioning and evolutionary process of the affected ecosystems; as well as measures and actions to facilitate the restoration of the rights of affected individuals and communities, through actions of compensation and indemnification, rehabilitation and through measures that guarantee the non-repetition and prevention of the recurrence of the damage. Reparation in the social field implies that persons, families, communities or villages affected by a negative environmental impact or environmental damage can return to living conditions and quality of life in dignity.

(Texto Unificado Legislación Ambiental Secundaria, 2015 , p. 8 [author's translation])

Integrating reparación integral in the legal framework can be interpreted as a reaction to the history of oil extraction in Ecuador and the severe damage that the oil industry had left behind, especially in its Amazon region. The extraction of oil involves toxic substances from the extracted material itself or the materials added in the process of extraction (Di Toro et al., 2007). Thus, production waste and spills_-if not handled appropriately — can lead to the contamination of groundwater and surface water, sediment, and soils, and thus degrading ecosystems and negatively affecting human health (San-Sebastián \& Hurtig, 2004). If wastes and spills are abandoned in the site without proper treatment, they remain constant sources of contamination - which is what the Ecuadorian legislation defines as pasivo ambiental (COA, Art. 807). According to the Ministry of Environment, oil companies left behind 3,877 such sites in all Ecuador (PRAS, 2018). As a state official put it:

The biggest challenge of the state is at the moment to understand how we can repair the damage done to the Amazon, especially in Orellana and Sucumbíos. I think the damage goes beyond what you can imagine, and whatever number we could put on it-it is incalculable, and so still we do not fully understand or dimension the reality of that damage. What we know is that people are still dying; we know that the ecosystem will take a long, long time to recover, and for now, we do not have much clarity where even to start, it is an incredible job, and it is very costly. The biggest challenge in this country when it comes to hydrocarbons is to solve the problem with environmental and social damages that were never repaired.

(Government official [Interview], 2015)

Reparación integral aimed at repairing the damage done to the Amazon and at preventing occurrence of such damage ever again in the future. That also included preventing oil companies from compensating for environmental damages in a way that is not proportionate to the actual dimension of the damage.

It is interesting to note how [oil] companies have taken over functions of the state, how they have built roads, water systems, huts, and some public 
health infrastructure. However, all these means were rather a palliative measure for the actual damage and in no way addressed the environmental damage in an integral way.

(Government Official [Interview], 2015)

Thus, reparación integral aimed at addressing the problems that emerged from dealing with environmental damages in the past.

\section{The program of social and environmental reparation (PRAS)}

A unique entity was created in 2008 at the Ministry of Environment: the Program of Social and Environmental Reparation (PRAS) to put reparación integral into practice. PRAS's mission was to "guarantee the reparación integral for environmental damages [caused by the inadequate management of economic activities] to contribute to the improvement of the quality of life of all Ecuadorians and the protection of the Rights of Nature" (Programa de Reparación Ambiental y Social, n.d., [author's translation]). To ensure the implementation of reparación integral across different economic sectors, PRAS has several different lines of work. First, PRAS curates an information system for socio-ecological liabilities. One of PRAS's main projects in its early years was to generate a database - called "Sistema de Indicadores Ambientales y Sociales (SIPAS)" - that aimed to register all existing pasivos ambientales in the oil and gas sector. Secondly, to study how to best carry out a reparación integral, PRAS develops pilot projects in zones identified as being the most affected by environmental damages. Third, PRAS develops methodologies and guidelines, mostly derived from their pilot projects, on how to measure damages in ecological and social terms, and what activities are subsequently required on the part of the industry to repair such damages. Fourth, PRAS assesses the plans of reparación integral that the industry must submit when it causes environmental damages. Lastly, PRAS is responsible for monitoring the process of reparación integral in situ, verifying the reparación integral of environmental damages in the field. The Department of Environmental Control at the Ministry of Environment oversees the laboratory results from the samples taken from the site where environmental damage occurred. It authorizes the completion of the remediation process, once the operator has complied with the environmental regulations. A decade after the creation of PRAS, the questions arise: How did PRAS perform? Did PRAS deliver on its promise to guarantee a reparación integral of the damages caused in the Ecuadorian Amazon? What are the most critical constraints that PRAS encountered?

\section{Limits to PRAS and the enforcement of reparación integral}

The following section presents the limits to the enforcement of reparación integral, exemplified through the interactions between PRAS and the cleanup project of the public oil company. In 2002 the public oil company (then Petroproducción, today Petroamazonas EP) initiated a cleanup project called Project to eliminate contaminated ditches and clean-up of oil spills in the Amazon District (PEPDA). After 2008, PEPDA had to adjust its operation to incorporate all dimensions of 
reparación integral. First, PRAS could not get the public oil company to adopt the concept of reparación integral consistently- to repair not only the environment but also the economic, social, and cultural damages. The high costs that the implementation of reparación integral translated into the watering down of the concept on the part of the public oil company. Before 2008, the sectorial regulation employed the term reparation as synonymous with remediation-reparation meant remediating contaminated soil, piscinas (large ditches), and oil spills in which more than five barrels were spilled (Reglamento Ambiental para las Operaciones Hidrocarburifferas en el Ecuador, 2010, Art. 16). After 2008, however, all remediation procedures had to incorporate the concept of reparación integral, which meant to beyond cleaning up soils. To "align the project with the new framework of the Ministry of Environment" (Petroecuador EP, 2012, p. 10), the public oil company integrated the concept of reparación integral into its cleanup projects in 2010. PEPDA subsequently became PRIPA, the Plan of the Integral Restoration of Pasivos Ambientales (PRIPA). PRIPA included not only measures for remediating soils, but also for restoring the social rights and the dignity of affected communities. However, with the split of the state oil firm into Petroecuador EP and Petroamazonas EP in 2013, the project was again re-conceived, operating from 2013 onwards under the name Amazonía Viva (Amazon Alive). The significant difference between PRIPA and Amazonía Viva was the re-definition of reparación integral as "environmental rehabilitation" while no longer including the restitution of social rights in the new project design. The project design of Amazonía Viva abandoned the social dimension, including the compensation, indemnification, and satisfaction of affected people and communities. Interviewees at Amazonía Viva said that this would not mean that Petroamazonas EP would not pay compensation and indemnification to affected persons and communities at all. It only meant that this did not fall into the scope of the project of Amazonía Viva anymore that only included the remediation of soils. While the Vice-presidency endorsed Amazonía Viva, which meant that it would receive priority status in the national budget allocation, interviewees nevertheless expressed concerns in 2015 that the budget for the project would shrink with falling oil prices. One can thus assume the change in the adoption of reparacion integral had likely to do with the uncertainty of how much money would even be required on the part of Petroamazonas EP to fulfill the compensation and indemnification requirements. So reparación integral shifted back from restoring rights to remediating soils.

The fact that the restitution of rights was no longer part of the cleanup project generated mistrust and conflicts among communities. Some community members did not want the damage in their territory to be cleaned up because they feared that then they would have no evidence that they also had a right to be compensatedeither financially or with a collective good. Therefore, they often refused entry on to their property, which, in turn, inhibited the clean-up from taking place:

People do not like that the pasivos get cleaned up as they fear that then they have no evidence anymore for receiving any compensation or indemnification.

(Government official [Interview], 2016) 
It remains unclear how and when Petroamazonas would start to compensate and indemnify affected people and communities for the pasivos ambientales. Community members also expressed concern about not being asked or even informed about how they would like the cleanup to take place, and that local social organizations would, unfortunately, have no say in the cleanup operations (Activist [Interview], 2018).

Second, even if focusing only on remediating soils, the cleanup process advances only very slowly "at the speed of a turtle" (Government official [Interview], 2015). PRAS registers 3,877 pasivos in all regions in Ecuador. Between 2005 and 2018, 1,488 pasivos were cleaned up, leaving 2,389 that still need to be dealt with in the years to come. That would mean that it would take more than 20 years to finish all cleanups in Ecuador-only remediating soils. According to the PRAS database, more fosas (small ditches) than piscinas (big ditches) were cleaned up over the years. Interviewees indicated that fosas were prioritized as they might be easier to remediate and thus lead more quickly to successful results. That means that remediating the outstanding piscinas will likely take even longer than the time it took to remediate fosas.

Additionally, old damage continues to be discovered, and new damage continues to be produced. The growing number of contamination sources is visible in the project reports-PEPDA indicated 1,420 sources of contamination in the Ecuadorian Amazon while Amazonía Viva indicates 2,550 (Petroamazonas EP, 2018). Likewise, the PRAS database from the year 2016 indicated a total of 3,658 pasivos ambientales, while the database from 2018 counted 3,877 (Bornschlegl, 2017; PRAS, 2018). As an interviewee said: "It will already take easily 10 to 15 years to remediate the damage that exists, and that alone if there would be no new pasivos produced. However, new pasivos continue to be produced all the time" (Corporate representative [Interview], 2015). The reason for this is that oil companies rarely replace those old infrastructures that generated most of the damages in the first place. Interviewees across the board say that it remains cheaper for the industry to pay the administrative fine for the environmental damage than to invest in new infrastructure. Some extraction sites are said to produce a spill almost daily (Government official [Interview], 2015).

These limits to reparación integral and the enforcement of environmental law, in turn, limit the possibilities for economic diversification in the regions in which extraction takes place.

The challenge is for us to have a region without contamination, and that a new productive sector can be created. The oil will disappear; the oil will end one day. However, if they [the oil companies] leave us contaminated with pasivos, for what do these rivers serve? For nothing. However, if they remediate, if they leave this region clean, that could be the start of a new productive activity, such as tourism. Here we have a great potential for tourism.

(Government official [Interview], 2015) 
Environmental damages are a threat to alternative economic sectors such as agriculture and tourism, specifically eco-tourism. If all that is left are degraded landscapes, there will not be many alternative economic sectors that could generate state revenues after resource depletion (Larrea, 2017). That is, economic diversification through sectors such as agriculture and tourism continue to be made impossible through environmental degradation (Perreault, 2013; Cuba et al., 2014). Instead of investing in the upgrading of mature sites, the extractive frontier expands, opening more and more new sites (Kaup, 2010).

\section{Conclusion}

The resource boom, as well as the Left Turn in Latin America, has brought new fodder to the question of whether natural resources can overcome the resource curse and finally lead to a socially and ecologically just development. Scholars examining the performance of progressive governments in the context of the resource boom have demonstrated their failure in bringing about any substantial structural transformation. This chapter found that institutional innovations were, however, established that could have contributed to advance a transformation away from extractivism, but did not. Taking reparación integral and its enforcement as example, this chapter has shown that insufficient funding and a lack of executive power did constrain the reach of these institutional innovations - constraints that are common explanations for the chronic weakness of environmental law enforcement.

There are several implications of these findings for research that examines institutional dynamics in the context of resource extraction, specifically for those working on the politics of institutions in the resource curse framework. In line with the argument of this book and others who have argued that institutions is too coarse of a term for adding to the understanding of the resource curse, this chapter maintains that further research should specifically study the trajectories of institutions that could be called progressive public institutions. It would be especially essential to replace the focus of which institutions lead to economic growth with the inquiry of which institutions serve the advancement of socially and ecologically just economies, as conceptualized by ecological economists. As North et al. (2017, p. 78) argue:

In countries with entrenched traditions of mining and hydrocarbon extraction, such as Bolivia and Peru, just leaving the stuff under the ground altogether is not realistic. Still, diversifying and shifting the balance of policies away from extraction and towards policies of employment generation and economic diversification, as described above, may bring about substantial social and economic advance.

For instance, why is there no sweeping tax reform? Why is there no sweeping agrarian reform? Some scholars have already laid the groundwork for this to be 
built upon (Alayza \& Gudynas, 2011; Gudynas, 2013; Escobar, 2015; Acosta \& Brand, 2017).

Thus, it would be essential to study how to build and sustain progressive institutions over time and across space. Further research could provide cross-national, longitudinal comparative in-depth analysis to questions as to how institutional innovations that critically confront extractivism could gain more traction in real politics, and how to translate economic alternatives to extractivism into political options that gain wider public acceptance (Peters, 2016). In doing so, one could focus, on the one hand, on political alliances and political capture. Who exactly obstructs institutional innovations from developing teeth, what channels of influence do they use, and what narratives and networks do they mobilize? One can build on research that has studied political capture and lobbying in the context of resource extraction (Crabtree \& Durand, 2017; Bebbington et al., 2018), and research that has examined cases such as the tobacco industry (Kessler, 2001), and climate change denial (Oreskes \& Conway, 2010). On the other hand, further research could examine why and how social mobilization can make progressive institutions gain wider public acceptance and political traction (Ospina Peralta et al., 2015). As Arendt (1969, p. 41) put it: "All political institutions are manifestations and materializations of power; they petrify and decay as soon as the living power of the people ceases to uphold them".

\section{References}

Acosta, A. (2017). Posextractivismo: Del discurso a la práctica-Reflexiones para la acción. International Development Policy | Revue Internationale de Politique de Développement, 9, 1-20. https://doi.org/10.4000/poldev.2496

Acosta, A., \& Brand, U. (2017). Salidas del laberinto capitalista. Decrecimiento y postextractivismo. Fundación Rosa Luxemburgo.

Acosta Ruiz, M., \& Iturralde, P. (2013). La alquimia de la riqueza. Estado, petróleo, y patrón de acumulación en Ecuador. Centro de Derechos Económicos y Sociales (CDES). ISBN: 978-9978-334-06-5

Addison, T., \& Roe, A. (2018). Extractive industries. The management of resources as driver of sustainable development. Oxford University Press. https://doi.org/10.1093/ oso/9780198817369.001.0001

Alayza, A., \& Gudynas, E. (Eds.). (2011). Transiciones. Postextractivismo y alternativas al extractivismo en el Perú. RedGe, CEPES. ISBN: 978-9972-722-19-6

Andreucci, D., \& Radhuber, I. M. (2017). Limits to "counter-neoliberal" reform: Mining expansion and the marginalization of post-extractivist forces in Evo Morales's Bolivia. Geoforum, 84, 280-291. https://doi.org/10.1016/j.geoforum.2015.09.002

Arendt, H. (1969). On violence. Harcourt Brace Jovanovich Publishers.

Bebbington, A., Abdulai, A.-G., Humphreys Bebbington, D., Hinfelaar, M., \& Sandborn, C. (Eds.). (2018). Governing extractive industries. Politics, histories, ideas. Oxford University Press. https://doi.org/10.1093/oso/9780198820932.001.0001

Bornschlegl, T. (2017). Three snapshots into complexity. A political ecological analysis of the regulatory enforcement of environmental laws in the oil and gas sector in Ecuador [Ph.D.-thesis]. Graduate School of Geography, Clark University. 
Bornschlegl, T. (2018). Petro-geographies and the dialectic of the everyday. Enforcing environmental laws in the hydrocarbon sector in post-neoliberal Ecuador. Journal of Latin American Geography, 17(3), 15-42. https://doi.org/10.1353/lag.2018.0040

Brand, U., Dietz, K., \& Lang, M. (2016). Neo-extractivism in Latin America. One side of a new phase of global capitalist dynamics. Ciencia Política, 11(21), 125-159.

Broad, R., \& Fischer-Mackey, J. (2017). From extractivism towards buen vivir: Mining policy as an indicator of a new development paradigm prioritizing the environment. Third World Quarterly, 38(6), 1327-1349. https://doi.org/10.1080/01436597.2016.1262741

Bull, B., \& Aguilar-Støen, M. (Eds.). (2015). Environmental politics in Latin America: Elite dynamics, the left tide and sustainable development. Routledge.

Bull, B., \& Aguilar-Støen, M. (2016). Changing elites, institutions and environmental governance. In F. De Castro, B. Hogenboom, \& M. Baud (Eds.), Environmental governance in Latin America (pp. 137-163). Palgrave Macmillan.

Burchardt, H. J., \& Dietz, K. (2014). (Neo-)extractivism-a new challenge for development theory from Latin America. Third World Quarterly, 35(3), 468-486. https://doi.org/10.1 080/01436597.2014.893488

Burchardt, H. J., Dominguez, R., Larrea, C., \& Peters, S. (2016). Nada dura para siempre. Neo-extractivismo tras el boom de las materias primas. Ediciones Abya-Yala. ISBN: 978-9942-14-842-1

Cori, A., \& Monni, S. (2014). The resource curse hypothesis: Evidence from Ecuador. SEEDS Working Paper Series 28.

Crabtree, J., \& Durand, F. (2017). Peru: Elite power and political capture. Zed Books. ISBN 978-1-78360-903-1

Cuba, N., Bebbington, A., Rogan, J., \& Millones, M. (2014). Extractive industries, livelihoods and natural resource competition: Mapping overlapping claims in Peru and Ghana. Applied Geography, 54, 250-261. https://doi.org/10.1016/j.apgeog.2014.05.003

Dargent, E., Orihuela, J. C., Paredes, M., \& Ulfe, M. E. (Eds.). (2017). Resource booms and institutional pathways. The case of the extractive industry in Peru. Palgrave Macmillan.

De Castro, F., Hogenboom, B., \& Baud, M. (Eds.). (2016). Environmental governance in Latin America. Palgrave Macmillan. https://doi.org/10.1057/9781137505729

Di Toro, D. M., McGrath, J. A., \& Stubblefield, W. A. (2007). Predicting the toxicity of neat and weathered crude oil: Toxic potential and the toxicity of saturated mixtures. Environmental Toxicology and Chemistry, 26(1), 24-36.

Escobar, A. (2015). Degrowth, postdevelopment, and transitions: A preliminary conversation. Sustainability Science, 10(3), 451-462.

Gilberthorpe, E., \& Papyrakis, E. (2015). The extractive industries and development: The resource curse at the micro, meso and macro levels. The Extractive Industries and Society, 2(2), 381-390. https://doi.org/10.1016/j.exis.2015.02.008

Gilberthorpe, E., \& Rajak, D. (2016). The anthropology of extraction: Critical perspectives on the resource curse. Journal of Development Studies, 53(3), 186-204. https://doi.org/10. 1080/00220388.2016.1160064

Gudynas, E. (2010). The new extractivism of the 21st century: Ten urgent theses about extractivism in relation to current South American progressivism. Center for International Policy.

Gudynas, E. (2011). Los derechos de la naturaleza en serio. In A. Acosta \& E. Martínez (Eds.), La naturaleza con derechos. De la filosofía a la política (pp. 239-287). Ediciones AbyaYala. ISBN: 978-9978-22-995-8

Gudynas, E. (2013). Transitions to post-extractivism: Directions, options, areas of action. In M. Lang \& D. Mokrani (Eds.), Beyond development: Alternative visions from Latin America (pp. 165-188). Transnational Institute. 
Kaup, B. Z. (2010). A neoliberal nationalization? The constraints on natural-gas-led development in Bolivia. Latin American perspectives, 37(3), 123-138. https://doi.org/10.1177\% 2F0094582X10366534

Kessler, D. (2001). A Question of intent: A great American battle with a deadly industry. Public Affairs.

Lang, M., \& Brand, U. (2015). Dimensiones de la transformación social y el rol de las instituciones. Introducción. In M. Lang, B. Cevallos, \& C. López (Eds.), ¿Cómo transformar? Instituciones y cambio social en América Latina y Europa (pp. 7-35). Abya-Yala. ISBN: 978-9942-09-317-2

Larrea, C. (Ed.). (2017). ¿Está agotado el período petrolero en Ecuador? Alternativas hacia una sociedad más sustentable y equitativa: un estudio multicriterio. Ediciones La Tierra. http://hdl. handle.net/10644/5812

Lu, F., Valdivia, G., \& Silva, N. (2017). Oil, revolution, and indigenous citizenship in Ecuadorian Amazonia. Palgrave Macmillan.

North, L., Grinspun, R., \& Larrea, C. (2017). Post-neoliberalism in Latin America: Continuities and discontinuities in regimes of extraction. In K. Kalowatie Deonandan \& M. Dougherty (Eds.), Mining in Latin America: Critical approaches to the new extraction (pp. 63-80). Routledge.

Oreskes, N., \& Conway, E. (2010). Merchants of doubts. How a handful of scientists obscured the truth on issues from tobacco smoke to global warming. Bloomsbury Press. ISBN: 9781596916104

Ospina Peralta, P. (2012). Promesas temporales. Cambio del régimen de acumulación en Ecuador, propuestas y realizaciones de la Revolución Ciudadana. In L. López, M. Molina, D. Pardo, J. Piedrahita, L. Rojas, N. Tejada, \& R. Zelik (Eds.), ¿Otros mundos posibles? Crisis, gobiernos progresistas, alternativas de sociedad (pp. 113-130). Fundación Rosa Luxemburgo/Universidad Nacional de Colombia. ISBN: 978-958-761-136-6

Ospina Peralta, P., Bebbington, A., Hollenstein, P., Nussbaum, I., Ramírez, E. (2015). Extraterritorial investments, environmental crisis, and collective action in Latin America. World Development, 73, 32-43. https://doi.org/10.1016/j.worlddev.2014.08.020

Papyrakis, E. (2017). The resource curse - what have we learned from two decades of intensive research: Introduction to the special issue. The Journal of Development Studies, 53(2), 175-185. https://doi.org/10.1080/00220388.2016.1160070

Perreault, T. (2013). Dispossession by accumulation? Mining, water and the nature of enclosure on the Bolivian Altiplano. Antipode, 45(5), 1050-1069.

Peters, S. (2016). Fin del ciclo: El neo-extractivismo en Suramérica frente a la caída de los precios de las materias primas. Un análisis desde una perspectiva de la teoría rentista. In H. J. Burchardt, R. Dominguez, C. Larrea, \& S. Peters (Eds.), Nada dura para siempre. Neo-extractivismo tras el boom de las materias primas (pp. 21-55). Ediciones Abya-Yala. ISBN: 978-9942-14-842-1

Petroamazonas EP. (2013). Amazonía viva: Proyecto Amazonía viva. Petroamazonas EP.

Petroamazonas EP. (2018). Memoria de gestión 2018: Proyecto Amazonía Viva. Petroamazonas EP.

Petroecuador EP. (2012). Plan de restauración integral de pasivos ambientales en el distrito Amazónico (PRIPA). Petroecuador EP.

Petroproducción. (2008). Proyecto: Eliminación de piscinas contaminadas y limpieza de derrames en el distrito Amazónico (PEPDA). Petroproducción.

Poteete, A. R. (2009). Is development path dependent or political? A reinterpretation of mineral-dependent development in Botswana. The Journal of Development, 45(4), 544-571. https://doi.org/10.1080/00220380802265488

Programa de Reparación Ambiental y Social-PRAS. (2015). Guía metodológica para la construcción de planes de reparación integral (PRI). Ministerio del Ambiente del Ecuador. 
Programa de Reparación Ambiental y Social-PRAS. (2018). Pasivos ambientales [Database]. Ministerio del Ambiente del Ecuador.

Programa de Reparación Ambiental y Social-PRAS. (n.d.). Amazonia viva/ Proceso de restauración. http://pras.ambiente.gob.ec/web/amazonia-viva

Reglamento Ambiental para las Operaciones Hidrocarburíferas en el Ecuador-RAOHE. (2010). Decreto Ejecutivo 1215. https://www.ambiente.gob.ec/wp-content/uploads/ downloads/2012/09/RAOHE-DECRETO-EJECUTIVO-1215.pdf

Ross, M. L. (2015). What have we learned about the resource curse? Annual Review of Political Science, 18, 239-259. https://doi.org/10.1146/annurev-polisci-052213-040359

San-Sebastián, M., \& Hurtig, A. K. (2004). Oil exploitation in the Amazon basin of Ecuador: A public health emergency. Revista Panamericana de Salud Pública, 15(3), 205-211. https:// doi.org/10.1590/S1020-49892004000300014

Sovacool, B. K. (2010). The political economy of oil and gas in Southeast Asia: Heading towards the natural resource curse? The Pacific Review, 23(2), 225-259.

Svampa, M. (2017). Del cambio de época al fin de ciclo. Gobiernos progresistas, extractivismo, movimientos sociales en América Latina. Edhasa.

Svampa, M. (2019). Las fronteras del neoextractivismo en América Latina. Conflictos socioambientales, giro ecoterritorial y nuevas dependencias. CALAS, Maria Sibylla Merian Center.

Texto Unificado Legislación Ambiental Secundaria, Reforma Libro VI. (2015). Acuerdo Ministerial 061. Registro Oficial Edición Especial 316 de 4 de Mayo 2015.

UN General Assembly. (2005). Resolution A/RES/60/147. Basic principles and guidelines on the right to a remedy and reparation for victims of gross violations of international human rights law and serious violations of international humanitarian law.https://www.ohchr.org/en/professionalinterest/pages/remedyandreparation.aspx

Veltmeyer, H., \& Petras, J. (2019). Latin America in the vortex of social change. Development and resistance dynamics. Routledge. https://doi.org/10.4324/9780429032042

Veltmeyer, H., \& Petras, J. (Eds.). (2014). The New extractivism. A post-neoliberal development model or imperialism of the twenty-first century? Zed Books. https://doi.org/10.1002/jid.3091

Villalba-Eguiluz, C. U., \& Etxano, I. (2017). Buen Vivir vs development (II): The limits of (neo) extractivism. Ecological Economics, 138(C), 1-11. https://doi.org/10.1016/j. ecolecon.2017.03.010 


\title{
13 Changes to the environmental monitoring institutions for the mining sector in San Juan, Argentina
}

\author{
Julieta Godfrid
}

\section{Introduction}

During the resource boom (2000-2013), mining in Argentina experienced unprecedented growth. In the late 1990s, the regulatory framework was amended to promote foreign investment (Moori Koenig \& Bianco, 2003), and the country's first two large-scale metalliferous mines, Bajo Alumbrera and Cerro Vanguardia, were established. Between 1998 and 2018, the value of Argentine mining exports rose by 400\% (Ministerio de Hacienda, 2019). As of 2021, the country hosts twelve active gold and silver mines, two lithium mines, and one coal mine, as well as another four mines currently in construction (Secretaría de Minería, 2021). Despite the growth in the sector, mineral extraction is still of secondary importance to the Argentine economy, accounting for just $0.57 \%$ of gross domestic product in $2020 .{ }^{1}$

Argentina's most-exported mineral is gold, which represents almost $4 \%$ of the country's total exports (Ministerio de Hacienda, 2019). In 2019, 2.2\% of the gold extracted worldwide came from Argentina (US Geological Survey, 2020), primarily Santa Cruz (59.64\%) and San Juan (39.18\%) (Secretaría de Minería, 2020).

The expansion of mining in Argentina was accompanied by transformations to the sector's institutional framework that remain little analyzed. The present study focuses on changes to the environmental monitoring institutions for the mining sector in the province of San Juan during the period 1993-2020specifically, those agencies under the auspices of San Juan's Secretariat of Environmental Management and Mining Oversight (Secretaría de Gestión Ambiental $y$ Control Minero, SGACM). We selected San Juan as the province with the second-largest volume of gold extracted in Argentina and that which accounts for half of the country's mining potential (Prensa Ministerio de Minería, 2019). Analysis at the subnational level is crucial to the Argentine case, as administration and oversight of natural resources falls upon the provincial governments, as established by the constitutional reform of 1994. In this chapter we ask the following questions: How do environmental monitoring institutions for mining change in the context of sectoral expansion? What factors have driven the changes? What types of institutions result? We argue that the political decision 
by the authorities in San Juan to prioritize mining conditioned the institutional change process and limited the capacity for environmental oversight as well as the means by which to respond to public demands for transparency and participation.

Our study draws on analysis of mining and environmental legislation at the levels of Argentina and San Juan province. Moreover, we explore institutional functionality, and the transformations thereto, by way of interviews conducted during our fieldwork in San Juan and in the departments of Iglesia and Jáchalcatalogued as areas of mining influence. ${ }^{2}$

Next, in the theoretical section, we provide a conceptual definition of our understanding of institutions and institutional change. Then, we analyze the transformations to environmental monitoring institutions for the mining sector in the province of San Juan, Argentina. In the analytical section we chart the historical development of the institutions starting from their creation in the 1990s, before looking at the factors that drive changes to the institutional framework. In the conclusions, we reflect on what the San Juan case tells us about the importance of the policy dimension for understanding processes of institutional change in extractive contexts.

\section{State institutions, reproduction, and institutional change}

Political institutions are rules, procedures, or mechanisms that formally (through organizations, legislation, or administrative bodies) or informally (through shared knowledge and values) curtail or enable political behavior (Levitsky \& Murillo, 2009; O’Donnell, 1996; North, 1990). In this chapter, we center on state institutions, understood as those with the authority to subordinate other parties by invoking the public interest, as well as the ability to channel resources in order to tackle public problems (Oszlak, 1984). Brinks et al. (2020), distinguished between strong and weak institutions: the former are those with the capacity to achieve the non-trivial goals they set themselves, while the latter neither propose nor accomplish ambitious goals. Institutional weakness can be witnessed in both the instability of existing rules and the failure to comply with them, whether due to technical inability or to conscious political decisions. The proposal of these authors is crucial in that it foregrounds the political dimension of institutional weakness.

For state institutions to be able to reproduce over time, they must gain social acceptance (Orrù et al., 1991) and adapt to the context (Hall, 2010). This requires either a process of gradual change (Mahoney \& Thelen, 2010) or jolts defined as "transient perturbations whose occurrences are difficult to foresee and whose impacts on organizations are disruptive and potentially inimical" (Meyer, 1982, p. 515). Institutional change can be recognized in a modification of the rules (Campbell, 2010) or the functions performed by these institutions (Streeck \& Thelen, 2005). The literature has identified that internal or external factors can lie behind these institutional changes. 


\section{Julieta Godfrid}

Among the most salient internal changes are the capacity of state agencies and their bureaucracies (Bersch et al., 2017; Evans, 1995), the economic resources that an institution has available (Hill \& Hupe, 2002), and surveillance and sanctionary mechanisms (Sabatier, 1986). Also influential is the institutional environment (Meyer \& Rowan, 1977; DiMaggio \& Powell, 1983), which refers to the shared beliefs and logics that guide an institution's agents.

The external factors that can drive transformations include: a) the socioeconomic context in which the institutions and their performance are socially perceived (Sabatier, 1986); b) the number of actors with power of veto that can limit the scope of an institution (Sabatier \& Jenkins-Smith, 1999); and c) the actions of social movements or collective actions of protest (Bosi et al., 2016; Giugni, 2007; Kolb, 2007; Silva, 2018; Zald et al., 2005).

The transformations to the mining institutions in Latin America over the last twenty years are of particular interest when analyzing the dynamics of institutional change. Much of the literature has identified contextual elements among the explanatory factors for institutional change; these can be top-down, led by the actors who concentrate power; or bottom-up, stemming from civil society or social organizations (Orihuela et al., 2021). The former includes the role played by international credit rating agencies in the pro-market reconfiguration of state institutions (Kuramoto \& Glave, 2007; Damonte, 2016; Svampa, 2019) as well as the influence of international trade agencies in state incorporation of environmental standards (Lanegra, 2018; Orihuela \& Paredes, 2017). Notable among the latter are the social conflicts that drive bottom-up change (Arce, 2014; Bebbington et al., 2018; de Echave et al, 2009). To respond to social conflicts, governments have utilized various mechanisms: redistributive (Arellano Yanguas, 2011), environmental (Orihuela \& Paredes, 2017), civic participation or consultation (de Echave, 2005; Leifsen et al., 2017; Jaskoski, 2014), and environmental monitoring (Himley, 2014).

\section{Environmental control of mining in the province of San Juan, Argentina}

In San Juan, the process of transforming the mining institutions began during the 1990s with the province's accession to Argentina's new regulatory framework around mining and the environment (Moscheni \& de la Torre, 2017). Argentina's mining institutions were reformulated under the Assistance Program for the Argentine Mining Sector (Programa de Asistencia para el Sector Minero Argentina, PASMA) financed by the World Bank and the International Bank for Reconstruction and Development (Moori Koenig \& Bianco, 2003). In a context of crisis for regional economies such as San Juan's, the central government used transfers from the national treasury to press the provinces into adopting the reforms (Favaro et al., 2006). The new mining legislation establishes a series of incentives to attract capital, including legal stability for thirty years and the limitation of royalties to $3 \%$ of the pit-head value (Table 13.1). As well as this external coercion, provincial deputies representing San Juan, such as José Luis Gioja, ${ }^{3}$ promoted legal reforms like amendments to the 
Mining Code and the Mining Investment Law (Álvarez Huwiler, 2013). Alongside these changes to the mining laws came amendments to the environmental legislation - which also affected the mining sector-as part of an institutional greening process at the national level (Gutiérrez \& Isuani, 2014). These legislative changes and adaptions to the mining and environmental regulations are outlined in Table 13.1.

In line with the provisions of the Environmental Protection Law for Mining Activity, San Juan's first two institutions tasked with the environmental monitoring of mining were created: the Research Center for the Prevention of Mining and Industrial Pollution (Centro de Investigación para la Prevención de la Contaminación Minero-Industrial, CIPCPAMI, 1996) the product of a technology transfer agreement with the Japan International Cooperation Agency (JICA); and the Provincial Environmental Management Unit for Mining (Unidad de Gestion Ambiental Minera Provincial, UPGAMP, 1998). The purpose of CIPCAMI was to monitor the water courses in areas where mines had been established. For its part, UGAMP was tasked with assessing the environmental impact reports submitted by mining companies at each operational stage, as well as the corresponding two-yearly updates. Both institutions, as well as the application of environmental protection (No.1426) or assessment (No. 6800) environmental legislation, are dependent on the provincial mining authority (currently the Ministry of Mining). That is, the environmental oversight of mining is left to the sphere of mining itself and not to the Secretariat of the Environment, which is responsible for other activities that might generate an environmental impact (Decree No. 504-L).

Table 13.1 Overview of mining and environmental regulations (1993-2002) ${ }^{4}$

\begin{tabular}{|c|c|c|c|}
\hline Argentina Law No. & $\begin{array}{l}\text { San Juan Law/Decree } \\
\text { No. }\end{array}$ & Year & Description \\
\hline 24,196 & $459-\mathrm{M}$ & 1993 & Mining investment \\
\hline 24,228 & & 1993 & Federal Mining Agreement \\
\hline \multirow[t]{3}{*}{24,498} & 7199 & 1995 & Update to Mining Code \\
\hline & 4392 & 1978 & Water Code for the Province \\
\hline & 6872 & 1998 & of San Juan \\
\hline \multirow[t]{3}{*}{24,585} & & 1995 & Environmental Protection Law \\
\hline & 1426 & 1996 & for Mining Activity \\
\hline & 6800 & 1997 & $\begin{array}{l}\text { Environmental Impact } \\
\text { Declaration }\end{array}$ \\
\hline 25,243 & & 1997 & $\begin{array}{l}\text { Supplementary Treaty on } \\
\text { Mining between Argentina } \\
\text { and Chile }\end{array}$ \\
\hline 25,675 & $513-\mathrm{L}$ & 2002 & General Environmental Law \\
\hline 25,688 & & 2002 & $\begin{array}{l}\text { Environmental Management } \\
\text { Regimen for Water }\end{array}$ \\
\hline
\end{tabular}

Source: Compiled by author 
The legal changes in the 1990s were key to the mining boom in San Juan, which began in 2003 with Barrick Gold's construction of Veladero. ${ }^{5}$ Other mines followed: Gualcamayo in 2009, which remained in operation in 2021, and Casposo, active from 2011 to 2019. Another gold and silver mining project was Pascua Lama, located in the border between Argentina and Chile; construction began in 2009 but was put on hold in 2020. ${ }^{6}$ In addition, San Juan has copper deposits that the José María project is looking to exploit. The initiation of new projects has translated into a larger share for mining and quarrying in the province's economy, having gone from 3\% of gross geographic product (GGP) in 2004 to $10.4 \%$ in 2018 (IIESJ, 2019). In 2018, mining accounted for $72 \%$ of exports from San Juan, whose main destination was Canada (Ministerio de Hacienda, 2019).

From 2003, with the arrival to the provincial government of José Luis Gioja (2003-2015), mining became state policy, involving the promotion of mining investment and the guarantee of legal stability for companies (Gioja, 2006). José Luis Gioja governed for three terms (2003-2015), adding to his majority on each occasion: in 2003, he won 38.12\%; in 2007, 51.81\%; and in 2011, 68.16\% (Ministerio del Interior, 2003, 2007, 2011). According to Gioja, mining was central to his election as governor: "I campaigned on mining. We opened Veladero on October 15th [2003] and the election was on the 23rd" (La Nación, 2006). Mining was the most promoted activity by the provincial government as well as the local press (Giovannini et al., 2009; Bottaro \& Álvarez, 2014). During his three terms, Gioja's vision was to "turn San Juan into a leading mining jurisdiction” (Ministerio de Minería, 2019). The political prioritization of mining over other activities was crystallized in the government slogan San Juan mining land, first employed by Gioja (Panorama Minero, 2012) and still in use in 2020, under the governorship of Sergio Uñac ${ }^{7}$ (Mining Press, 2020; Gobierno de San Juan, 2020). For San Juan's political authorities, mining promotion became an extractive imperative (Arsel et al., 2016) that conditioned the process of institutional change we analyze here.

\section{Gradual changes driven by social demands, 2003-2014}

In San Juan, social conflicts around mining broke out in parallel with the construction of Veladero (Bottaro \& Álvarez, 2014; Christel, 2020), and were centered mainly on the departments of Calingasta and Jáchal. Inhabitants deployed a broad repertoire of collective actions ${ }^{8}$ aimed at obtaining information, rejecting water concessions for mining, and calling for instances of civic participation and consultation.

Through social mobilization, large-scale mining became a socially problematized issue, and the matter of environmental monitoring of mining gained traction on the provincial political agenda (Henríquez \& Nozica, 2010). Thus, the increased visibility of the conflict pressured San Juan's subnational government into introducing institutional changes within this sphere. The province's chief mining institution was gradually afforded greater hierarchical prominence; in 
2006 it was promoted from the Subsecretariat to the Secretariat of Mining, and then in 2010 it became the Ministry of Mining. Similarly, in 2006 the Unit for Environmental Management of Mining (UGAM) became the Subsecretariat, and then, in 2010, the Secretariat of Environmental Management and Mining Oversight (Secretaría de Gestión Ambiental y Control Minero, SGACM).

In turn, between 2004 and 2006 three new institutions were created: the Consultative Mining Council (Consejo Consultivo Minero, CCM; Decree No. 1108); the Interdisciplinary Commission for Environmental Assessment of Mining (Comisión Interdisciplinaria de Evaluación Ambiental Minera, CIEAM; Decree No. 1815) and the Multidisciplinary Environmental Assessment Commission for Mining (Comisión Evaluadora Multidisciplinaria Ambiental Minera; 1679-2006 M). The recitals in the regulations refer to "justified social concern" and the need for "greater institutional and social oversight" (No. 1815). The aim of CCM was to create a body responsible for "reaching consensus and voicing opinion" (Decree No. 1108). CIEAM was tasked with the environmental assessment of large-scale mining projects, and CEMAM medium- and small-scale projects.

The new bodies called, almost without exception, institutions involved in mining or under the control of the provincial government. For example, CCM was made up of fourteen institutions that the founding decree classed as qualified to pass opinion. These included the Secretariat of Mining, the Argentine College of Mining Engineers (Colegio Argentino de Ingenieros en Minas), the Professional Council of Geological Sciences (Consejo Profesional de Ciencias Geológicas), the Mining Chamber of San Juan (Cámara Minera de San Juan), and the Argentine Mine Workers' Assocation (Asociación Obrera Minera Argentina). The passage of consultative opinions required a quorum of at least twelve people, and the vote of half plus one of the representatives. In the case of a tie, the vote of the undersecretary of mining was worth two. Analysis of CCM minutes indicates a lack of critical voices (Ministerio de Minería, n.d.). The body was only active from 2004 to 2008 (Ministerio de Minería, n/d; Borges \& Rittner, 2010).

For its part, the CIEAM also proved impervious to social demands for participation and transparency (Henríquez \& Nozica, 2010). Pursuant to Decree No. 1815 , CIEAM is composed of fifteen institutions; ${ }^{9}$ of these, eleven are directly answerable to the provincial government of San Juan, which appoints the leaders of these institutions. Of the rest, two are institutions that answer to the Argentine state, and the other two are autonomous universities. The exclusion of other independent actors, or those who might offer a broader perspective during the assessment process, attests to the strict political control that the San Juan government exercised over the new environmental oversight institutions, just as it did over other mining institutions (Haslam \& Godfrid, 2020).

As had occurred during the 1990s, the institutional changes owed to external factors, but this time it was a bottom-up development arising out of social conflict. However, the demands for civic participation or consultation were not met in the way that the social organizations wanted. The state responded formally to the social demands by creating new rules and agencies, though their 
implementation was limited because of restricted civic participation as well as funding shortfalls. Dargent and Urteaga (2016) characterized this type of state response, in which institutions are formally created or symbolic actions taken but hampered by inadequate funding or implementation, as reactive. Similarly, Levitsky and Murillo defined the bodies that result from such changes as "window-dressing institutions" that political leaders seek to keep "on the books" (2009, p. 120) in formal terms, but with little interest in actual application.

The outcomes of the changes reflect an institutional framework for environmental oversight of mining that is weak in terms of its failure not only to accomplish the goals it formally sets itself, but also-through the systematic exclusion of critical voices - to address the social concerns around mining. Nor does it succeed in improving the technical capacity for environmental oversight. According to information gathered through the interviews and the secondary sources, the technical capacity of the Secretariat for Environmental Management of Mining, the monitoring capacity of the CIPCAMI, and the assessment capacity of CIEAM present various deficiencies.

After ten years of activity, the Japanese cooperation agency responsible for the initial technology transfer assessed CIPCAMI and passed judgement on its "low sustainability" (JICA, 2007, p. 3). Among other things, JICA highlighted the provincial government's underfunding of CIPCAMI, outmoded technology, inability to retain trained professionals, and failure to create self-financing mechanisms (JICA, 2007). With the exception of some equipment acquired in 2000 and later in $2010,{ }^{10}$ most of CIPCAMI's technology was not renewed until 2018 (Irusta, 2018). As well as the funding and staffing shortages, the Iglesia and Jáchal residents we interviewed expressed significant distrust of the data produced by CIPCAMI given its proximity to mining interests. Evidence of this distrust can be seen in the emergence of community water monitoring initiatives in Jáchal as an alternative to CIPCAMI (Ulloa et al., 2021).

According to some of the officials from CIEAM ${ }^{11}$ interviewed, the body experienced high staff turnover due to unpaid overtime or lack of professional recognition for the work they did. There was no institutional memory that new entrants could draw from, giving rise to a pronounced asymmetry of knowledge between the mining companies (which submitted their reports every two years) and the officials assessing them. Nor was there any delimitation of which section of the environmental impact report that each institution should assess, resulting in overlaps in some cases and under-recording in others. Assessment was primarily conducted on the basis of the extensive corporate reports, with little scope for on-site observation. Finally, the opinions issued by CIEAM were placed before the San Juan's chief mining authority for consideration, and in practice the decisions concerning the environmental impact declaration were more political than technical. Finally, according to the SGACM officials interviewed, in 2018 and 2019 the body was hindered by insufficient specialized personnel, low pay (which impeded retention), and precarious employment contracts. The previously mentioned capacity, resource, and equipment limitations did nothing to obstruct the passage of any mining projects, all of which 
received the necessary approval from SGACM and the Ministry of Mining to proceed with the respective project stages. This is key to understanding that the weakness of the environmental oversight institutions for mining is down to a deliberate political decision on the part of the provincial government, which prefers that they exist on paper rather than assuring their implementation.

\section{Changes due to jolts caused by environmental accidents, 2015-2019}

On September 13, 2015, an environmental accident occurred at Veladero in which almost one million liters of "cyanide-bearing process solution" was discharged into the Jáchal basin (Barrick Gold Corporation, 2020, p. 108). The Ministry of Mining and the company delayed in informing the public of the fact, and the social conflict in Jáchal was stirred up again (Casas \& Carelli, 2018; Godfrid \& Damonte, 2020). The government of San Juan fined Barrick Gold (Redacción Perfil, 2015), and the Ministry of Mining announced it will modernize environmental oversight (Pastor, 2016). In 2016, the secretary of environmental management and mining oversight was replaced by the hitherto manager of the Casposo mine. Upon assuming office, the new secretary said: "This role is something totally different, but I feel good because I wasn't a stranger to these people. . . . Here [at SGACM] he who wasn't a student, was a colleague" (Tiempo de San Juan, 2016). The change represented a closed-shop solution that again involved actors who were invested in assuring the endurance of large-scale mining in the province.

In May 2016, the Ministry of Mining announced that it would increase the salaries of its mine inspectors, though this measure was not implemented at that time. From September to November that same year, the inspectors only conducted office-based tasks and disrupted mine oversight in protest at the unrealized salary rise (Huella Minera, 2016). In September 2016, there was another operational accident at Veladero, this time, a mineralized material spill (Barrick Gold, 2018). The courts in San Juan suspended the project from September 16 to October 3 (Télam, 2016), and the provincial government imposed a new financial penalty. Once the suspension was lifted, residents of Jachal took the municipality building, demanding the mine's permanent closure as well as environmental remediation (Larreta et al., 2018). Several of our interviewees from Iglesia and Jáchal felt that the government abandoned them in the immediate aftermath of the 2016 accident, pointing to a "lack of controls" and to "corrupt," "deplorable" officials who were co-opted by corporate might. Residents of Jáchal engaged in demonstrations to demand a plebiscite on mining, but the provincial legislature did not approve one (Casas \& Carelli, 2018). That same year the residents teamed up with environmental organizations for a protest in Buenos Aires over non-compliance with the National Law on Glaciers (No. 26,639). ${ }^{12}$ In addition to the demonstrations, San Juan inhabitants filed two criminal complaints against the company for its part in the accident, and against the provincial government as well as national-level officials for noncompliance with environmental regulations (Mira, 2016). 
As with the accident in 2015, the government's response was reactive, seeking to tackle the problem by announcing more funding: "more investment, more oversight" (Prensa Ministerio de Minería, 2018). The Ministry of Mining announced the acquisition of new vehicles for on-site inspections, as well as the expansion of its workforce (Tiempo de San Juan, 2016).

In March 2017, there was a third accident, a spill of mineralized material and chemical substances (Barrick Gold Corporation, 2018). The pattern that followed was the same as the previous two cases: temporary suspension, fine, social protests, and the announcement of a battery of measures to improve environmental oversight. In 2018, the number of mine inspections increased (Prensa Ministerio de Minería, 2019); cameras were installed to observe Veladero in real time as part of a program called Mining Big Brother (Prensa Ministerio de Minería, 2018); and CIPCAMI's cyanide-detection equipment was renewed (Irusta, 2018). The following year, SGACM opened its new headquarters after a two-year construction effort that cost 100 million pesos (Mining Press, 2019).

In addition, a whole new series of measures were announced that, after the social pressure abated, were not ultimately implemented. For example, in 2017 a new law (No. 1600-P) stipulated that municipalities in which mining was practiced could appoint an environmental prosecutor. But as of 2021, none of San Juan's municipalities had appointed anyone to such a role. Also in 2018, the Ministry of Mining signed an agreement with the Universidad Nacional de San Juan to produce an information system for environmental monitoring of mining. On this, the Minister of Mining noted: "In this way we well have transparent, agile, and truthful management of all information" (Aguirre, 2018). However, the necessary software was not implemented due to "political decisions" (interview with official from the San Juan Ministry of Mining, 12/4/2019).

As our analysis shows, at this stage the new measures that the government incorporated into the institutional framework for the environmental oversight of mining were also reactive, in the face of social conflict and environmental accidents. The pre-existing formal rules and bodies (CIPCAMI, CIEAM, CEMAM) were kept, and at this stage the changes were focused on a series of measures and announcements related to the renewal of the institutional leadership, as well as additional staff members, equipment, and funding. That most of the measures were announced on the government's news portal right after the disruptive events attests to their symbolic and political nature. The result of the changes introduced was a reactive institutional framework with neither the adequate technical capacity for environmental monitoring nor the requisite levels of public confidence in mining oversight. Consequently, San Juan is still blighted by civic mistrust regarding the government's environmental oversight of mining. In the words of one member of a Jáchal citizen assembly, "It is the attitude, not the building, that has to change; it is not an infrastructure problem" (Interview in Jáchal, 12/7/2019). 


\section{Conclusion}

This Argentine case shows, as with other regional examples (Dargent \& Urteaga, 2016), that the mining boom was accompanied by reactive institutional change. In San Juan, the transformation of environmental monitoring of mining has primarily been a reaction to external factors: coercion by international agencies (1993-2002), socio-environmental conflicts (2003-2014), and mining accidents (2015-2019).

The first stage of these changes was marked by the reformulation of the regulatory framework and the development of new sectoral institutions. In the 1990s, the legislative foundations were laid to position San Juan as one of the main destinations for foreign mining investment in Argentina, and they remain intact to this day. The second and third stages were characterized by the effects of social conflict and mining accidents. As a result of social protests, environmental control of mining became an issue of public interest that the San Juan government could not overlook. This public pressure prompted the creation of regulations, bodies, laws, and bureaucratic departments for the environmental oversight of mining that did not previously exist at the subnational level. However, the social demands were only met in formal terms, on paper.

Unlike the study by Dargent and Urteaga (2016), in our analysis we find that the changes introduced did not bring about an institutional strengthening process. On the contrary, in San Juan there is evidence that the institutional framework for environmental oversight of mining is weak, insofar as it does not meet the statutory goals proposed, the measures it implements are of limited long-term sustainability, and it has failed to gain public trust.

Following the proposals of Levitsky and Murillo (2009) and Brinks et al. (2020), we understand that institutional weakness corresponds to a political decision and a strategy to introduce formal amendments (place them on the books) that do not fundamentally alter the status quo. In the case of San Juan, institutions are created that in statutory terms are aimed at improving environmental oversight mining, but which, because of political decisions, are starved of the financial or technical resources they need to assure compliance. The statutory objectives of the institutions also include the implementation of mechanisms for addressing social concerns or promoting consensus, but actors with views that are critical of mining have been systematically excluded or denied the opportunity to participate in civic consultations. Thus, political authorities use different tactics in order not to fully implement the institutional changes incorporated. In line with the analysis of Maillet and Carrasco (this volume), we observe an apparent change in the institutions that entails transformations to the formal rules, but not substantive modifications that challenge extractive policies.

And while these institutional changes remain strictly formal, they still play a key role in legitimizing institutions in order to adapt to the wider context (Levistky \& Murillo, 2009). That is, the incorporation of institutional changes into the sphere of environmental oversight of mining in San Juan can be 


\section{Julieta Godfrid}

understood as a strategy to legitimize the subnational government. In this regard, Brinks et al. (2020) have highlighted that changes to the institutional facade allow governments to legitimize their actions before international audiences that demand the incorporation of global standards, whether in terms of human rights, the environment, or other areas. This strategy of legitimation for international audiences can be observed in the overtures that the San Juan government makes to global investors, in which environmental management, mining oversight, transparency, and communication are cited as fundamental pillars of mining policy. But in addition to this purpose, in federal systems such as Argentina's in which the stewardship of natural resources depends on the subnational levels, the incorporation of institutional changes-however superficial_ can also be central to ensuring governance.

For subnational administrations, the cost of not responding to social issues can be high, as evidenced by other studies on mining conflict in Argentina (Christel, 2020). However, as a final reflection, we believe that it is important to continue exploring the extent to which these changes, or apparent changes, to the institutional facade actually contribute to legitimizing institutions, or, conversely, whether they only make their limitations more apparent.

\section{Notes}

1 Compiled by author based on Instituto Nacional de Estadísticas y Censos (2021a, b), "Series por sector de actividad económica: valor bruto de producción y valor agregado bruto. Años 2004-2020, por trimestre" and "Series trimestrales de oferta y demanda globales. Años 2004-2020”, www.indec.gob.ar/indec/web/Nivel4-Tema-3-9-47 (Accessed 20/04/2021).

2 We carried out a total of 140 semi-structured interviews with subnational government officials, lawyers, and representatives of NGOs, foundations, socio-environmental assemblies, agricultural producers' associations, irrigation boards, neighbors' unions, chambers of commerce, and mining companies. The interviews took place in September 2016; September, November, and December 2018; and December 2019. The fieldwork was carried out in collaboration with Dr. Lautaro Clemenceau and with funding from the Argentine National Council of Scientific and Technical Research (Consejo Nacional de Investigaciones Científicas y Técnicas de la Argentina) and the Ford Foundation.

3 José Luis Gioja was deputy for the province of San Juan (1987-1991); deputy in the Argentine Chamber of Deputies (1991-1995); governor of the province of San Juan (2003-2015) and president of the Partido Justicialista, Argentina's biggest political party (2016-2021).

4 This table presents some of the most representative mining and environmental laws.

5 In 2017, 50\% of Veladero was acquired by Shandong Gold Group.

6 In 2020, a Chilean court ordered the permanent closure of Pascua-Lama for breaches of its environment qualification resolution (Primer Tribunal Ambiental, 2020).

7 Sergio Uñac served as vice-governor of San Juan from 2011 to 2015, then as governor for two terms (2015-2019 and 2019-2023).

8 Repertoires of collective action are defined as a set of cultural practices learned during the process of social struggle that allow forms of protest to be expanded in a creative way (Tilly, 2002).

9 Each institution is required to appoint a named representative and an alternate.

10 In 2000, CIPCAMI acquired a device to check for the presence of chloride, and another for cyanide. 
11 We interviewed representatives of seven different member institutions of CIEAM in 2016, 2018, and 2019.

12 Law No. 26,639, sanctioned in 2010, establishes the Minimum Budgets Regime for the Preservation of Glaciers and the Periglacial Environment.

\section{References}

Aguirre, C. (2018, November 5). La Provincia contará con software propio para el monitoreo ambiental minero. Servicio informativo Gobierno de San Juan. https://bit.ly/3xop3Sn

Álvarez Huwiler, L. (2013). Políticas públicas y movimientos de capital: Un análisis a partir de las políticas de promoción de inversiones extranjeras en el sector minero metalifero argentino entre 1992 y 2007 [Doctoral thesis]. Universidad de Buenos Aires.

Arce, M. (2014). Resource extraction and protest in Peru. University of Pittsburgh Press.

Arellano Yanguas, J. (2011). Aggravating the resource curse: Decentralization, mining and conflict in Peru. Journal of Development Studies, 47(4), 617-638. https://doi. org/10.1080/00220381003706478

Arsel, M., Hogenboom, B., \& Pellegrini, L. (2016). The extractive imperative and the boom in environmental conflicts at the end of the progressive cycle in Latin America. Extractive Industries and Society, 3(4), 877-879. hdl.handle.net/11245.1/8d0bd84f-002b-4fe0bb92-98741f98c79b

Barrick Gold Corporation. (2018). The new value champion: Annual report 2018. Barrick Gold Corporation. http://q4live.s22.clientfiles.s3-website-us-east-1.amazonaws. com/788666289/files/annual-report/Barrick-Annual-Report-2018.pdf

Barrick Gold Corporation. (2020). Annual information form. Barrick Gold Corp. q4live. s22.clientfiles.s3-website-us-east-1.amazonaws.com/788666289/files/annual-report/ Barrick-Annual-Information-Form-2019.pdf

Bebbington, A., Fash, B., \& Rogan, J. (2018). Socio-environmental conflict, political settlements, and mining governance: A cross-border comparison, El Salvador and Honduras. Latin American Perspectives, 46(2), 84-106. https://doi.org/10.1177\%2F0094582X18813567

Bersch, K., Praça, S., \& Taylor, M. M. (2017). State capacity, bureaucratic politicization, and corruption in the Brazilian State. Governance, 30(1), 105-124. https://doi.org/10.1111/gove.12196

Borges, A., \& Rittner, D. (2010, April 21). San Juan: Consejo consultivo tiende a desaparecer. Mining Press. http://miningpress.com/nota/47176/san-juan-consejo-consultivo-minerotiende-a-desaparecer-

Bosi, L., Giugni, M., \& Uba, K. (Eds.). (2016). The consequences of social movements. Cambridge University Press. https://doi.org/10.1017/CBO9781316337790

Bottaro, L., \& Álvarez, M. (2014). La promoción del modelo minero en contextos subnacionales. Un recorrido analítico por las provincias de La Rioja y San Juan, Argentina. OSAL, 36. portal.amelica.org/ameli/jatsRepo/68/6823015/html/index.html

Brinks, D., Levistky, S., \& Murillo, M. V. (2020). The political origins of institutional weakness. In D. Brinks, S. Levistky, \& M. V. Murillo (Eds.), The politics of institutional weakness in Latin America (pp. 1-40). Cambridge University Press.

Campbell, J. L. (2010). Institutional reproduction and change. In G. Morgan, J. Campell, C. Crouch, O. Pedersen, \& R. Whitley (Eds.), The Oxford handbook of comparative institutional analysis (pp. 87-117). Oxford University Press. https://doi.org/10.1093/oxfor $\mathrm{dhb} / 9780199233762.003 .0005$

Casas, J., \& Carelli, J. M. (2018). La Asamblea Jáchal no se toca y la correlación de fuerzas en la lucha contra el extractivismo. RevIISE- Revista de Ciencias Sociales y Humanas, 10(10), 287-298. www.ojs.unsj.edu.ar/index.php/reviise/article/view/177 


\section{Julieta Godfrid}

Christel, L. (2020). Resistencias sociales y legislaciones mineras en las provincias argentinas. Los casos de Mendoza, Córdoba, Catamarca y San Juan (2003-2009). Política y Gobierno, 27(1), 3-24.

Damonte, G. (2016). Minería, estado y comunidades: Cambios institucionales en el último ciclo de expansión extractiva en el Perú. Un balance de investigación. In Grupo de Análisis para el Desarrollo (GRADE) (Ed.), Investigación para el desarrollo en el Perú: Once balances (pp. 403-444). GRADE. www.grade.org.pe/wp-content/uploads/LIBROGRADE_ DESARROLLO35.pdf

Dargent, E., \& Urteaga, M. (2016). Respuesta estatal por presiones externas: Los determinantes del fortalecimiento estatal frente al boom del oro en el Perú (2004-2015). Revista de Ciencia Política, 36(3), 655-677. https://doi.org/10.4067/S0718-090X2016000300003

De Echave, C. J. (2005). Los procesos de diálogo y la administración de conflictos en territorios de comunidades: El caso de la mina Tintaya en el Perú. CooperAcción.

De Echave, C. J., Diez, A., Huber, L., Revesz, B., Ricard Lanata, X., \& Tanaka, M. (2009). Minería y conflicto social. CBC, CIPCA, CIES, IEP. repositorio.iep.org.pe/bitstream/ handle/IEP/639/huber_mineriayconflictosocial.pdf;jsessionid=B68C015A42D0FBC74 00563D4BDA6893C? sequence $=2$

DiMaggio, P., \& Powell, W. (1983). The iron cage revisited: Institutional isomorphism and collective rationality in organizational fields. American Sociological Review, 48(2), 147-160. https://doi.org/10.2307/2095101

Evans, P. (1995). Embedded autonomy: States and industrial transformation. Princeton University Press.

Favaro, O., Iuorno, G., \& Cao, H. (2006). Política y protesta social en las provincias argentinas. In G. Caetano (Ed.), Sujetos sociales y nuevas formas de protesta en la historia reciente de América Latina (pp. 93-141). CLACSO. ISBN 987-1183-64-1

Gioja, J. L. (2006). Política minera provincial: "Nos espera un futuro venturoso". Ministerio de Minería. http://serviciosmineria.sanjuan.gob.ar/politica/politica.php

Giovannini, S., Orellana, M., Rocchietti, D., \& Vega, A. (2009). La construcción de San Juan como capital nacional de la minería: El concierto de voces entre el Estado y los medios de comunicación. In M. Svampa \& M. Antonelli (Eds.), Minería transnacional, narrativas del desarrollo y resistencias (pp. 255-275). Biblos.

Giugni, M. (2007). Useless protest? A time-series analysis of the policy outcomes of ecology, antinuclear, and peace movements in the United States, 1977-1995. Mobilization, 12(1), 53-77. https://doi.org/10.17813/maiq.12.1.b05j1087v7pxg382

Gobierno de San Juan. (2020). San Juan, Mining Land. https://miningland.sanjuan.gob.ar/en/

Godfrid, J., \& Damonte, G. (2020). La Provincia de San Juan entre la promoción minera y la defensa del agua: "Narrativas territoriales" en disputa. Quid, 16(13), 85-112.

Gutiérrez, R., \& Isuani, F. (2014). La emergencia del ambientalismo estatal y social en Argentina. Revista de Administração Pública, 48(2), 295-322. https://doi.org/10.1590/0034-76121700

Hall, P. (2010). Historical institutionalism in rationalist and sociological perspective. In J. Mahoney \& K. Thelen (Eds.), Explaining institutional change: Ambiguity, agency, and power (pp. 204-223). Cambridge University Press. https://doi.org/10.1017/ cbo9780511806414.009

Haslam, P., \& Godfrid, J. (2020). Activists and regulatory politics: Institutional opportunities, information, and the activation of environmental regulation. Extractive Industries and Society, 7, 1077-1085. https://doi.org/10.1016/j.exis.2020.06.019

Henríquez, M., \& Nozica, G. N. (2010). Participación ciudadana y actividad minera. La experiencia en la provincia de San Juan, Argentina. RevIISE-Revista de Ciencias Sociales y Humanas, 1(1), 115-122. www.ojs.unsj.edu.ar/index.php/reviise/article/view/11 
Hill, M., \& Hupe, P. (2002). Implementing public policy. Sage Publications. https://doi. org/10.1017/S0047279403227288

Himley, M. (2014). Monitoring the impacts of extraction: Science and participation in the governance of mining in Peru. Environment and Planning A: Economy and Space, 46(5), 1069-1087. https://doi.org/10.1068/a45631

Huella Minera. (2016, November 21). Policía minera no sale a inspeccionar. https://bit.ly/3gFDKur

Instituto de Investigaciones Económicas y Estadísticas San Juan. (2019). Producto geográfico bruto de la provincia de San Juan. Gobierno de San Juan. https://drive.google.com/drive/ folders/1ekAWmgMZVbJzoHQLCRUgDcSB_Jp7_Yw7

Instituto Nacional de Estadísticas y Censos. (2021a). Series por sector de actividad económica: Valor bruto de producción y valor agregado bruto. 2004-2020, by quarter. www.indec.gob.ar/ indec/web/Nivel4-Tema-3-9-47

Instituto Nacional de Estadísticas y Censos. (2021b). Series trimestrales de oferta y demanda globales. 2004-2020. www.indec.gob.ar/indec/web/Nivel4-Tema-3-9-47

Irusta, Á. (2018, July 19). Suman tecnología que logra acelerar el análisis ambiental. Diario de Cuyo. https://bit.ly/3vodJE6

Japan International Cooperation Agency- JICA. (2007). Ex-post evaluation of the Project "Mine Pollution Control Research Center (CIPCAMI) in the Republic of Argentina”. JICA. https:// bit.ly/3gNTPg1

Jaskoski, M. (2014). Environmental licensing and conflict in Peru's mining sector: A pathdependent analysis. World Development, 64(C), 873-883. https://doi.org/10.1016/j. worlddev.2014.07.010

Kolb, F. (2007). Protest and opportunities: The political outcomes of social movements. Campus.

Kuramoto, J., \& Glave, M. (2007). La minería peruana: Lo que sabemos y lo que aún nos falta por saber. In GRADE (Ed.), Investigación, políticas y desarrollo en el Perú (pp. 135-181). GRADE.

La Nación. (2006, February 26). Gioja: "Es imposible que se pueda contaminar". www.lanacion. com.ar/politica/gioja-es-imposible-que-se-pueda-contaminar-nid784018/

Lanegra, I. (2018). El camino ambiental hacia la OCDE-El Perú y la implementación de las recomendaciones en materia ambiental. Oxfam, Cooperacción, Propuesta Ciudadana. cooperaccion.org.pe/wp-content/uploads/2018/10/17070-El-camino-ambiental-hacia-laOCDE-CORR-web.pdf

Larreta, G., Sánchez, V., Donoso Ríos, M., \& Rodríguez, R. (2018). La Asamblea Jáchal no se toca: Crónica de una catástrofe. RevIISE- Revista de Ciencias Sociales y Humanas, 10(10), 257-270. hdl.handle.net/11336/102962

Leifsen, E., Vázquez, L. S., \& Reyes, M. (2017). Claiming prior consultation, monitoring environmental impact: Counterwork by the use of formal instruments of participatory governance in Ecuador's emerging mining sector. Third World Quarterly, 38(5), 10981109. https://doi.org/10.1080/01436597.2017.1294980

Levitsky, S., \& Murillo, M. V. (2009). Variation in institutional strength. Annual Review of Political Science, 12, 115-133. https://doi.org/10.1146/annurev.polisci.11.091106.121756

Mahoney, J., \& Thelen, K. (Eds.). (2010). Explaining institutional change: Ambiguity, agency and power. Cambridge University Press.

Meyer, A. D. (1982). Adapting to environmental jolts. Administrative Science Quarterly, 27(4), 515-537. https://doi.org/10.2307/2392528

Meyer, J., \& Rowan, B. (1977). Institutionalized organizations: Formal structure as myth and ceremony. American Journal of Sociology, 83(2), 340-363. www.jstor.org/stable/2778293

Mining Press. (2019, October 2). Control en tiempo real: el objetivo del nuevo edificio de Minería. https://bit.ly/3vkRsaa 


\section{Julieta Godfrid}

Mining Press. (2020, December 17). San Juan tierra minera, negocios reales. https://bit.ly/3gUFwX7

Ministerio de Hacienda. (2019). Informes de cadenas de valor. Minerales metaliferos: oro. Presidencia de la Nación Argentina. www.argentina.gob.ar/sites/default/files/sspmicro_cadenas_de_valor_mineria_metalifera_oro.pdf

Ministerio del Interior. (2003). Elecciones Generales escrutinio definitivo San Juan. https://bit. ly/3m87QI3

Ministerio del Interior. (2007). Elecciones provinciales escrutinio definitivo San Juan. https://bit. ly/3AME3uH

Ministerio del Interior. (2011). Elecciones nacionales distrito San Juan. https://bit.ly/3zPvMoe

Ministerio de Minería (n.d.). Actas del consejo consultivo minero ( $\left.N^{o} 1-N^{o} 32\right)$. http://serviciosmineria.sanjuan.gob.ar/consejo/ccm.php

Ministerio de Minería de San Juan. (2019). San Juan destino de inversiones mineras [Conference presentation]. Prospectors and Developers Association of Canada Convention. http:// enernews.com/media/briefs/pdac-2019-la-presentacion-de-san-juan-argentina_2911.pdf

Mira, J. (2016). Controversias de competencia judicial ambiental en un sistema federal: Reflexiones a favor del "federalismo ambiental". Actualidad Jurídica Ambiental, 63, 3-26. www.actualidadjuridicaambiental.com/wp-content/uploads/2012/01/2016_12_Recopilatorio_63_AJA_Diciembre.pdf

Moori Koenig, V., \& Bianco, C. (2003). Estudios sectoriales 1 EG.33.6. Componente: Industria minera. CEPAL-ONU. www.funcex.org.br/material/redemercosul_bibliografia/ biblioteca/ESTUDOS_ARGENTINA/ARG_97.pdf

Moscheni, M. del C., \& de la Torre, D. (2017). Tres décadas de políticas estatales mineras en Argentina: La continuidad de la omisión. RevIISE-Revista de Ciencias Sociales y Humanas, 10(10), 243-257. www.ojs.unsj.edu.ar/index.php/reviise/article/view/181/pdf

North, D. (1990). Instituciones, cambio institucional y desempeño económico. Fondo de Cultura Económica.

O’Donnell, G. (1996). Otra institucionalización. Revista Ágora, 5, 5-28.

Orihuela, J. C., Mendieta, A., Pérez, C., Ramírez, T. (2021). From paper institutions to bureaucratic autonomy: Institutional change as a resource curse remedy. World Development, 143, 105463. https://doi.org/10.1016/j.worlddev.2021.105463

Orihuela, J. C., \& Paredes, M. (2017). Fragmented layering: Building a green state for mining in Peru. In E. Dargent, J. C. Orihuela, \& M. Paredes (Eds.), Resource booms and institutional pathways: The case of the extractive industry in Peru (pp. 97-117). Palgrave Macmillan.

Orrù, M., Biggart, N., \& Hamilton, G. (1991). Organizational isomorphism in East Asia. In W. Powell \& P. DiMaggio (Eds.), The new institutionalism in organizational analysis (pp. 361-389). University of Chicago Press.

Oszlak, O. (1984). Teoría de la burocracia estatal: Enfoques críticos. Paidós.

Panorama Minero. (2012). Revista panorama minero, 394-398. https://panorama-minero. com/

Pastor, V. (2016, February 2). Minería refuerza el control con inspectores y tecnología. Mining Press. https://bit.ly/3dQ14nl

Prensa Ministerio de Minería. (2018, August 29). El gran hermano minero para control ambiental a distancia y en tiempo real. Servicio informativo Gobierno de San Juan. https://bit. ly/3gGrJF8

Prensa Ministerio de Minería. (2019, December 20). Minería realizó 538 inspecciones durante 2019. Servicio informativo Gobierno de San Juan. https://bit.ly/32MBf1f

Primer Tribunal Ambiental. (2020). Cuenta pública 2020. Antofagasta: Primer Tribunal Ambiental-República de Chile. www.1ta.cl/wp-content/uploads/REPORTE-1TA-EXTENDIDO-1.pdf 
Redacción Perfil. (2015, March 12). Millonaria multa a Barrick por el derrame de cianuro en Veladero. https://bit.ly/2QntM2s

Sabatier, P. (1986). Top-down and bottom-up approaches to implementation research: A critical analysis and suggested synthesis. Journal of Public Policy, 6(1), 21-48. https://doi. org/10.1017/S0143814X00003846

Sabatier, P., \& Jenkins-Smith, H. (1999). The advocacy coalition framework: An assessment. In P. A. Sabatier (Ed.), Theories of the policy process (pp. 117-166). Westview Press.

Secretaría de Minería. (2021, January 18). Informe mensual coyuntura minera. Ministerio de Desarrollo Productivo de Argentina. www.argentina.gob.ar/sites/default/files/informe_ mensual_coyuntura_minera_-_diciembre_2020.pdf

Secretaría de Minería. (2020a). Minería Argentina 2020. Primer semestre. Ministerio de Desarrollo Productivo de Argentina. https://bit.ly/3dQG9Ao

Secretaría de Minería. (2020b). Producción argentina de principales metales; oro, plata, litio, cobre, cinc y plomo. Ministerio de Desarrollo Productivo de Argentina. www.argentina.gob.ar/ sites/default/files/informe_de_producciones_metaliferas_principales_final_2018_1.pdf

Silva, E. (2018). Mega-projects, contentious politics, and institutional and policy change: Chile, 1994-2017. European Review of Latin American and Caribbean Studies, 106, 133-156. https://doi.org/10.32992/erlacs.10391

Streeck, W., \& Thelen, K. (2005). Introduction: Institutional change in advanced political economies. In W. Streeck \& K. Thelen (Eds.), Beyond continuity: Institutional change in advanced political economies (pp. 1-39). Oxford University Press.

Svampa, M. (2019). Las fronteras del neoextractivismo en América Latina. Conflictos socioambientales, giro ecoterritorial y nuevas dependencias. Bielefeld University Press. https://doi. org/10.14361/9783839445266

Télam. (2016, October 4). La justicia sanjuanina levantó la suspensión a la mina Veladero. https:// bit.ly/3gG6rYc

Tiempo de San Juan. (2016, November 7). Policía minera sumó inspectores y cámaras de vigilancia propias. https://bit.ly/3wKrJck

Tilly, C. (2002). Repertorios de acción contestataria en Gran Bretaña 1758-1834. In M. Traugott (Ed.), Protesta social, repertorios y ciclos de la acción colectiva (pp. 1-17). Edit. Hacer.

Ulloa, A., Godfrid, J., Damonte, G., Quiroga, C., \& López, A. P. (2021). Monitoreos hídricos comunitarios: Conocimientos locales como defensa territorial y ambiental en Argentina, Perú y Colombia. ICONOS- Revista de Ciencias Sociales, 25(69), 77-97. https://doi. org/10.17141/iconos.69.2021.4489

US Geological Survey. (2020). Mineral commodity summaries 2020: U.S. Geological Survey. USGS. https://doi.org/10.3133/ mcs2020

Zald, M., Morrill, C., \& Rao, H. (2005). The impact of social movements on organizations. In G. Davis, A. Arbor, D. McAdam, R. Scott, \& M. Zald (Eds.), Social movement and organizations theory (pp. 253-279). Cambridge University Press. https://doi.org/10.1017/ CBO9780511791000.014 
$\because$ Taylor \& Francis

Taylor \& Francis Group

http://taylorandfrancis.com 
Part 3

Conclusions and road ahead 
$\because$ Taylor \& Francis

Taylor \& Francis Group

http://taylorandfrancis.com 


\title{
14 Institutional change in extractive economies
}

\author{
A research agenda from the Andes
}

\author{
Bettina Schorr and Gerardo Damonte
}

\section{Introduction}

The observation that resource-rich states tend to struggle with a whole series of political and economic problems - the curse - has prompted vigorous debates among scholars trying to decipher the causes and consequences of this fatal relationship. Institutions are at the heart of this debate: It is argued that in absence of a strict regulatory framework, the different expressions of the curse will appear. Moreover, the resource curse perpetuates itself by preventing the emergence of functioning regulatory institutions. In this way, this argument points to a vicious cycle that implies an unavoidable fate for the many resourcerich countries in the world characterized by weak institutional capacities, as the Andean countries are.

In contrast to these foundational tenets of the resource curse approach, we find that the Andean region demonstrates that the pathologies of the curse and institutional change towards mitigating it can take place at the same time. Expressions of the curse can be detected throughout the region, from macroeconomic problems to social conflicts and political dysfunctionalities to environmental and health damage. This is even true for the case of Chile, generally considered an outlier among the Andean cursed nations, because of its cautious macroeconomic management and the high quality of its institutions (World Bank, 2019). Some authors even argue the country has managed to overcome the curse (Haslam, 2016; Saylor, 2014). Yet, scholars in this book (Maillet and Carrasco, Rabi and Campos) argue that it depends where you look at: Chile is facing serious environmental and other local problems related to its extractive economy, which can be interpreted as manifestations of the curse. Thus, applying a comprehensive typology of the dimensions of the curse (Orihuela, 2018), the different manifestations can definitely be identified throughout the Andean region.

At the same time, institutions have been established or changed in order to tackle the problems associated with the extractivist development models promoted in the Andes. Against the daunting predictions of the resource curse approach, the different chapters of this volume reveal a wide array of innovations in regulatory and redistributive institutions. These include fiscal reforms 
and social policy innovations, anti-corruption and participatory reforms, as well as environmental regulation. Thus, confirming that important institutional changes to tame the resource curse can occur under the conditions of resource economies characterized by weak state structures is the first important contribution of this volume. This finding is further backed by recent scholarship proclaiming a whole inclusionary turn (Kapiszewski et al., 2021) for Latin America that is diagnosed on the basis of the adoption of many of those political institutions required to mitigate the different expressions of the curse.

By exploring the ways these institutions have emerged and how they perform, the chapters of this volume add further insights to the incipient discussion on institutional change in resource-dependent contexts. In a general perspective, they find that institutional change and performance in the Andean resource economies must be understood as phenomena that are much more complex than pictured by the resource curse literature. Institutional change can be triggered by different actors through a diverse set of pathways and involving different causal mechanisms. By extension, the book underscores that institutions have to be understood as the result of ongoing social processes embedded in specific domestic political and cultural contexts as well as shaped by global dynamics.

In the remainder of this concluding chapter, we lay out a first draft of a research agenda on institutional change and performance in resource-dependent contexts. For this agenda, we distil a series of hypotheses and theoretical implications from the books' chapters that may be valid across different countries and regions. Based on these, we raise a couple of relevant questions for further research. Our nascent research agenda includes six thematic areas: 1) governments and institutional change in resource economies; 2) beyond the government: the role of non-state actors and international organizations; 3 ) the patterns, sequencing, and timing of institutional change; 4) institutional design and implementation; 5) context matters: the national and subnational contexts; and 6) informal institutions in resource governance. These areas are certainly interdependent but focus on different aspects of institutional change and performance under the conditions of resource dependence. We elaborate on each briefly and close with some final remarks.

\section{Governments and institutional change in resource economies}

Governments adopting the types of institutional change capable of easing the resource curse are not only wishful thinking of international organizations and NGOs promoting the good governance of the extractive sector. In the Andean region, governments acting out of their own intrinsic motivation (without domestic or external pressure) have indeed been active promoters of institutional change with the potential of mitigating the resource curse by using their executive powers or by mobilizing their legislative majorities. While the chapters of this book focus on individual institutions, it should not be forgotten 
that in several countries governments also promoted institutional change on the macro level: during the latest commodity boom, Venezuela, Bolivia, and Ecuador wrote and adopted new constitutions which at least on paper significantly reshaped state-society relations in an inclusive way (Kapiszewski et al., 2021; Schilling-Vacaflor \& Nolte, 2012).

It should also be stressed that governments promoting institutional change by using the rents of the resource sector is not a new phenomenon. Historical research into state building in Latin America has repeatedly emphasized that political elites have invested resource rents to strengthen state capacity in order to be able to provide collective goods and promote economic growth and social well-being among their citizens. Such was the case in 19th-century Chile, where domestic elites used the rents stemming from the nitrate boom to build up the public administration of the country and its infrastructure (Kurtz, 2013). As a matter of fact, the Chilean state is as robust as it is today amongst others because of this strategic use of resource rents in the past (Soifer, 2016). Also, in Peru the rents flowing from the guano boom into the states' accounts were used by President Ramón Castilla in the mid-19th century to strengthen state capacity (Kurtz, 2013; Bonilla, 2020). Likewise, Saylor (2014) has showed that commodity booms can act as windows of opportunity for state building when the export sector forms part of the domestic ruling coalition, which he found for the cases of Chile and Argentina.

Certainly, building up a strong state does not necessarily equate to the political will to address all the different dimensions potentially affected by the resource curse. Even in the case of the strong Chilean state, environmental regulation has not been on the governments' agenda and had to be pushed on it from the outside (see later). The point to be stressed here is that both in the distant as well as in the recent past, governments have promoted institutional changes towards the mitigation of the resource curse, reflecting Dietsche's (2007) assertion that political will can make a difference (for institutions). Against this background, one important question to be addressed by future research should target the intrinsic incentives driving governing elites to bring about institutional changes in specific sectors.

In this sense, it has been shown that new regulation concerning the governance of the extractive sector was often motivated by the desire to attract foreign capital requiring a clear legal framework (Bebbington \& Bury, 2013). While redistributive institutions are sometimes viewed as the domain of leftist governments (Campello, 2015; Levitsky \& Roberts, 2011), the new fiscal rules and social policies as studied by Jiménez and Evia (this volume) were introduced in the region regardless of the political color of the sitting governments (Fairfield \& Garay, 2017). Haslam and Heidrich (2018) stress that during the latest boom resource nationalism defined as states' actions to enhance its influence over the extractive sector by the maximization of public revenue, the assertion of strategic state control, and the enhancement of developmental spill-overs from extractive activities could be found anywhere in the region. They differentiate, though, between radical and modest versions of resource nationalism, as found 
in Venezuela and Colombia respectively. Hence, rather than ideological factors, greater profits in the extractive sector combined with electoral incentives stemming from citizens' demands for redistribution seem to have promoted institutional change in these sectors (Fairfield \& Garay, 2017). However, the actual extension of these reforms seems to depend on ideology.

The flip side of exploring the intrinsic incentives for governments to reform would be to identify the sectors where governments resist institutional change. In other words, further research should explore what is persistently missing in terms of institutional change and why. One prime example for such a missing reform can be found in the fiscal sector. While minor reforms regarding taxing citizens have been introduced for instance in Chile and Colombia, thorough progressive tax reforms are notoriously absent in the whole region (Atria et al., 2018). This absence persists notwithstanding the mantra of experts in the field who emphasize that progressive tax systems would be essential to tackle the majority of the problems associated with the resource curse. In particular, a progressive tax system would stabilize domestic resources and reduce the economic dependence from the volatile global commodity markets. Moreover, it is argued that state-society relations based on progressive taxes - the fiscal pact-promote transparency and increase the accountability of public officials.

Yet, the lack of a fiscal contract that some authors argue is the main problem of resource-dependent economies (Moore, 2004; Karl, 2007) has been perpetuated through the latest boom cycle in the region. In several cases, scholars have identified elite lobbyism as one factor avoiding tax reforms in the region (Fairfield, 2015; Bogliaccini \& Luna, 2016.). As shall be discussed later, this has serious consequences for the sustainability of some of the institutional reforms that did take place.

In other occasions, government may have the intention to change but need to impose it against reluctant rent-seekers in the legislature or other private powerful actors. The first may be of particularly importance for the Latin American presidential systems, in which political preferences of presidents and legislatures can differ sharply. To overcome legislative or elite resistance, strategic coalitions with civil society organizations and international organizations may be helpful (Schorr, this volume). Regarding elite resistance, research has found that it is less pronounced in boom times (Campello, 2015), when business elites are integrated into cohesive networks (Cárdenas, 2020) and when elites actually are aware of social problems they command the power to redress (Reis \& Moore, 2005).

\section{Beyond the government: the role of non-state actors and international organizations}

Institutional change is not always the product of the genuine political will of governments. Reflecting the argument that under the adverse conditions of resource economies institutional change is at best difficult, this book shows that in many instances of change, governments had to be pressured to adopt 
new rules. This highlights the importance of non-state actors and international organizations in promoting institutional change in resource economies and reveals the limits of the state as a driver for institutional change. The state rather constitutes an arena of contention where different actors strive for imposing their own institutional agendas. Thus, just as examining intrinsic motivations of governments is important, further research may explore under which conditions non-state and international actors can promote institutional change, in which sectors and how.

As showed in this book, in some cases the pressure for change derived from social mobilizations and protests, both nationally as well as regionally and locally. This has been found for the adoption of new environmental rules by the San Juan provincial government in Argentina, new policies for citizen participation and political transparency in Chile and Peru, and changes in the formalization norms for small-scale mining in Madre de Dios, Peru (see the chapters by Godfrid, Schorr and Damonte). As Bornschlegl and Cisneros, Evia, and Flemmer (this volume) note for the cases of Ecuador, Bolivia, and Peru respectively, many institutional changes with redistributive or regulatory character carried out during the latest boom represented long-standing demands of different mobilized social groups, such as unions, peasant organizations, or indigenous groups.

In other cases, international organizations (e.g. OECD, ILO, World Bank) and donor cooperation put pressure on governments by tying institutional change to material (credits, funds etc.) or symbolic rewards, for instance in the case of the environmental systems in Chile and Peru (chapters by Maillet and Carrasco; Rabi and Campos and Paredes and Figueroa). By the same token, Flemmer (this volume) highlights the importance of national and transnational advocacy networks in pushing the Peruvian government to regulate the ILO 169 agreement regarding indigenous consultation by enacting a national consultation law. As shall be discussed in more detail in the next section, domestic mobilization and external pressure often converged to push governments towards institutional change.

The involvement of national and transnational non-state actors and international organizations in processes of institutional change has several implications: In a practical sense, it reveals the leverage of international actors that holds the potential of supporting or empowering domestic reform coalitions, not just governments. On the other hand, institutional change propagated by these actors may provoke problems associated with institutional isomorphism: They may constitute a no fit condition and be ineffective in the respective local context (we elaborate on this point later). Further research should identify the conditions under which local mobilizations and international leverages interact to produce effective institutional change.

As mentioned in our introduction, business actors may also influence institutional change and performance in resource-dependent contexts. So far, research on how business can affect institutions often focusses on business elites as promoters of extractive institutions that ensure their privileged access to resources (i.a. Madariaga et al., 2021; Durand, 2016; Bull \& Aguilar-Støen, 2015). However, 
as stated earlier, under certain conditions business actors have also been found to support inclusive institutions. Haslam (2016) and Saylor (2014) mention the important role of business actors in promoting efficient regulatory institutions, thereby preventing the states from succumbing to the curse.

Also, transnational initiatives, such as the EITI or the International Council on Mining and Metals (ICMM), involve companies as actors in processes of institutional change in the member states. Regarding the latter, authors discuss whether they have to be understood as a corporate version of window dressing institutions or whether they have a real effect on constraining corporate and political behavior detrimental to the good of society. This point about how to differentiate between self-serving expediency and positive influence should be addressed in more detail in future research.

Another incipient stream of research explores the consequences of corporate behavior in host communities, where they carry out their projects. In particular, it has been argued that companies by means of their CSR programs have a strong impact on the daily routines of communities, i.e. how these communities organize their economies and social life. It has also been argued that CSR programs generate unexpected and undesired institutional consequences: Where corporate services substitute for public service delivery (like access to water, public infrastructure etc., as for example in Peru), in the longer run this may interrupt or slow down processes of institutional strengthening on part of the state by eroding citizens' demands towards the state (Bebbington, 2010). Future research may confirm empirically this relationship between corporate activities on the local level and institutional defects on the national level and identify the expressions it may take.

\section{The patterns, sequencing, and timing of institutional change}

Processes of institutional change in resource-dependent contexts may follow specific patterns and timings. The chapters of this book indicate the significance of different patterns of involvement of state and non-state actors in different policy sectors.

As mentioned earlier, governments were promotors of sectoral regulation and of institutions that capture a higher share of the sectors' rents, increase redistribution, or provide social assistance. In contrast, environmental institutions have not been placed first on governments' agendas, which may confirm the resource curse literatures' argument of politicians being myopic and refraining from putting hard constraints on the sector. The empirical cases analyzed in this book may indicate that or international organizations with leverage capacity or massive domestic social movements (partly supported by transnational advocacy) or a mix of both are key in promoting institutional change in the environmental sector. Certainly, this assertion is not meant to be exclusive. International pressure was also present in other sectors (e.g. the transparency reforms in Chile prior to its acceptance to the OECD) and massive regionally based social 
movements have demanded fiscal decentralization in Peru. Occasionally, governments have adopted and implemented environmental programs as shown in Bornschlegl's study on integral reparation in Ecuador. Notwithstanding these single cases, empirical evidence of this book may lead us to hypothesize a certain bias towards the environmental sector that reflects the sectoral preferences of international agencies as well as social values (environmental protection) and local grievances (contamination) on part of domestic non-state actors. Future research may explore if this tendency constitutes a robust relationship and, if so, find the underlying causes. More especially, it would be important to find and explore cases of governments adopting institutions for environmental protection without external pressure (i.e. by intrinsic motivation).

The chapters of this book also allow us to address hypotheses with regard to the timing and sequencing of institutional change under the adverse conditions of resource economies. Two patterns can be discerned. The first connects institutional change promoted by international actors to domestic challengers and may imply that a sequence is at work. In cases where international pressure established a formal framework against reluctant governments, social pressure and protest may be necessary to activate or enhance its transformatory effect. The first was the case with the translation of the international convention of prior consultation into actual Peruvian law in the context of the Bagua conflict (Flemmer, this volume). The second can be found in case of environmental legislation in San Juan, Argentina, which was first introduced on the basis of international factors (the Rio Convention and Japanese donor cooperation) and then further refined to the rhythm of social mobilizations. For this reason, and drawing on a concept coined by Dargent and Urteaga (2016), Godfrid (this volume) speaks of a type of reactive change that is only adopted when social pressure on governments is so high as to make it unavoidable.

This statement contrasts with the problems that has been mentioned related to institutional isomorphism. In the case of the Peruvian OEFA, Paredes and Figueroa (this volume) argue that the externally promoted institution could not count on social support, which contributed to its weakness. On the other hand, institutional change imposed against the resistance of states by domestic challengers may be more sustainable when international actors use their leverage to push for effective implementation of these institutions (we return to this point later).

Second, the opportunities for institutional change may also vary along the boom-post-boom divide depending on the presence or absence of economic windfalls. Some institutional changes, such as the increase of the states' share of the extractive sectors' rents, may be easier to achieve during boom times when the overall profits are high. As mentioned, scholars have argued that business elites are more willing to support or at least not obstruct state interventions into the economy in times of fat cows when a higher redistribution is not perceived as a loss (Campello, 2015).

Other institutional changes might be easier to adopt in times of economic downturn, when the incentives set by the exuberant profits of the sector have 
receded. Transparency reforms may be a case in point. As Moreno shows (this volume), across the Andean region social perception of corruption has increased significantly only after the latest commodity boom has ended. Likewise, it was only towards the end of the boom that many countries saw the revelation of mega corruption scandals and social disapproval increased until opening up a window of opportunity for transparency reformers (Schorr, this volume). The causal mechanisms underlying this finding should be explored in more detail. They might mirror the results from studies conducted in other world regions that reveal people tend to ignore some of the fallacies of resource economies (such as authoritarianism and corruption), whilst the general perception is that everybody wins (Jones Luong \& Weinthal, 2009 for the post-Soviet republics). Ignoring the fallacies associated with resource dependence would then be an important barrier to institutional change, and more information of potential pitfalls could act as a redress.

Fiscal reforms may also be a case in point. Jiménez (this volume) raises the question of whether the post-boom period could be a good moment to alter fiscal redistribution schemes adopted during the boom period that significantly contribute to territorial inequalities in the region. In a variation of the argument regarding the reduction of elite resistance against redistributive measures during boom times, he argues that the post-boom could constitute a window of opportunity. Since it can be assumed that the losses a further reform of the fiscal system would generate would be lower for the affected subnational jurisdictions in times of economic bust, also their resistance might be lower. As an implication, times of thin cows might in some sectors constitute better moments for promoting institutional change.

Altogether, these different trajectories, patterns, and sequences lead us to better understand the diachronic feature of institutional change. Institutional change is not a linear process that unfolds following a pre-designed manual or guideline; it is rather a social process whose trajectory depends heavily on the social conditions and power balances among state and non-state actors. Suitable social conditions and favorable power balances may create opportunities to overcome the maladies associated with the resource curse so that social actors are able to push forward institutional changes.

\section{Institutional design and implementation}

While this book confirms that institutional change took place rather frequently, almost all chapters reveal deficiencies in at least one of two interrelated areas: institutional design and implementation. The authors of several chapters argue that institutions lost their innovative elements and objectives during implementation, and even ended up reproducing the negative social situations and behaviors that they were intended to change. The chapters underscore, thus, that full-fledged institutional change towards mitigating the resource curse should be grasped as a two-step process in which the emergence, adoption, or sound design of new institutions does not in itself assure effective implementation. 
Scholars and practitioners alike should pay attention to these complexities and focus not only on the adoption of curse-preventing institutions in resource economies, but analyze in much more detail the way they are designed and the consequences of their design for the achievement of their statutory goals as well as the constraints operating upon their effective implementation.

Regarding design, several chapters in this book show that new institutions have been adopted which for their name and statutory goals would seem to be able to constrain behavior conducive to the manifestations of the resource curse. At times, the establishment of, for example, new environmental ministries have elicited approval and praise on the part of international actors and donor cooperation. However, when a closer look at these institutions is taken, it becomes clear that they have been designed by powerholders in such a way that their consequences are ultimately minimal. Thus, these institutions seem to represent window dressing institutions formally adopted to please external actors (such as international organizations) or to ease internal pressures (such as social mobilizations). Maybe a renewed version of the resource curse should not focus on the presence or absence of regulatory institutions, but on the way they are set up and function (or do not function). The authors of this book have described the lack of impact in the face of factual formal institutional change by using different concepts: Flemmer detects unwanted change in the case of prior consultation in Peru that has been legally downsized in the national legal framework. Maillet and Carrasco find apparent change in the Chilean extractive sector. These authors also argue that change is limited to the environmental subsector and has almost no constraining effect on the dominant extractive regime as demonstrated in the persistent increase of both the number of projects as well as the number of social conflicts these provoke (a similar argument is presented by Paredes and Figueroa for the case of the Environmental Ministry in Peru). Maillet and Carrasco (this volume) also state that business has actively lobbied for specific institutional designs, in order to evade actual constraints. In Peru (Paredes and Figueroa, this volume; Durand, 2016) and Ecuador (Cisneros, this volume) as well, mining industries have been found to influence the design of the sectoral regulation (environmental and other) to cushion its effects on their interests. Likewise, Rabi and Campos (this volume) argue that business-friendly political forces in the Chilean Congress have designed the Environmental Courts in a way that intentionally reduces their scope of action and, with it, their potential to constrain ecologically harmful activities.

Defects by design are not always the product of a strategic political calculus, but may also represent unanticipated or undesired side effects. The chapters by Jiménez and Evia (this volume) make this point by laying out the consequences in terms of territorial inequalities and financial unsustainability, respectively. These two chapters also underscore another aspect important for scholars and practitioners alike: the interdependence of policy sectors. This aspect has been addressed by the institutional analysis literature as the institutional complexity of current societies (Campbell, 2010), in which changes in one institution can affect other institutions. Fiscal reforms and social policy reforms are a case in 
point: When the fiscal system fails to provide public resources in a sustainable way, social policy instruments may lose their transformatory potential once the boom and its windfalls vanish. In other words, it is important to address the different policy sectors required for mitigating or avoiding the curse, in a comprehensive way and simultaneously. Future research should address these interdependencies in order to obtain a better understanding of the workings of institutional complexities in resource economies.

Another important factor constraining the implementation of new institutions is the lack of money that is directly related to the dynamics of extractive economies. Several authors in this volume point out to the problem of lack of resources which arises from the cyclicity and volatility of global commodity markets (see also Vos, 2012; Campello \& Zucco, 2021). Once the boom recedes, the money needed to implement institutional changes for instance in the environmental sector (Bornschlegl, this volume) or in the social or public sectors (Evia and Jiménez, this volume) will run short. Even the attempt to diversify the extractive sector in Ecuador has been curbed when the rents from the oil sector decreased (Cisneros, this volume). At the same time, as mentioned before, it may be that precisely these moments of economic downturn can act as windows of opportunities for specific institutional changes, even with fewer financial resources.

Other factors found in the chapters of this book to be affecting institutional implementation are unrelated to the dynamics of the resource economy. These include for instance the lack of bureaucratic or professional capacity (Paredes and Figueroa, this volume), the lack of trust in the state (Bornschlegl, this volume), as well as the lack of executive power of public agencies to enforce institutions across the national territory (Bornschlegl, Damonte, this volume).

The latter two factors underscore that institutional implementation-like institutional emergence - is basically a function of power, and that social agency is fundamental for understanding institutional implementation. Particularly, power and cultural dynamics shape institutional implementation in contexts where the state is not the only actor holding power and may not even be the most powerful one. Throughout the chapters in this volume, we learn about how transnational corporations and local elites have reduced the new institutions' transformative elements, for the sake of private profits. On the other hand, non-hegemonic social actors have been shown to shape the implementation of new public policies through resistance and mobilization.

We finish this section on institutional design and implementation with two reflections. The first concerns the problems related to institutional isomorphism. Since in resource economies institutional change may depend to a higher degree on international pressure (at least in specific sectors, as discussed before), a research agenda focusing on the effective implementation of institutions in resource economies should be attentive to the problems of no fit: governments may import uncritically institutional frameworks developed under different conditions that do not fit their own national, regional, or local social dynamics and are, hence, prone to failure. Isomorphism and territorial no fit 
may affect institutional implementation, as shown in the chapters by Paredes and Figueroa and by Damonte (this volume). In both cases, imported institutions (the Peruvian Environmental Ministry as a case of global isomorphism and the state formalization plans imposed by the Peruvian central government to regulate mining activities in the Peruvian Amazonia) were seen as alien by the people supposed to comply with them (the rule takers, in the words of Streeck and Thelen (2005)). As a consequence, they refused to do so. Future research should focus on the mechanisms that may allow to foster the adjustment and grounding of national and international policies to specific contexts and territories so that they can work effectively.

Second, what institutions actually accomplish and the effects they have do not only depend on design and enforcement. As Rabi and Campos (this volume) argue, the effects of an institution are also a function of how they are used by social actors, mirroring (without mentioning) the argument of institutional analysts regarding the discretionary potential that all institutions (to some extent) have. The authors show that the Environmental Courts in Chile do not necessarily act as protection shields for the environment. They are more often used by business actors precisely to dispute state decisions grounded in environmental concerns. And those actors tend to be successful. Most decisions of these courts benefit project holders and not the local communities complaining over environmental damage. Thus, the actual use of institutions and how this use might be related to the dynamics of resource economies should also be of concern to a research agenda on institutional dynamics under the conditions of resource dependence.

\section{Context matters: the national and subnational levels}

We stated at the beginning of this chapter that processes of institutional change need to be understood and analyzed as ongoing processes, embedded in specific local, national, and global contexts. In fact, the chapters of this volume show that specific contexts matter greatly for explaining and exploring the opportunities for institutional change and effective implementation.

The universe of potential contextual factors that may condition institutional dynamics in resource economies is wide and includes amongst others specific state-society relations, political settlements, culture and economic contexts, and the quality of democratic institutions. We give an example for each: Regarding state-society relations, the alliance between informal miners and the government in Bolivia structured the governance of the informal gold mining sector in Bolivia in a way that prevents the effective implementation of regulatory institutions (Amengual \& Dargent, 2020). Cultural factors matter when the presence (Bolivia, Chile) or absence (Ecuador) of the idea that countries are and have always been "mining countries" influences if the mining sector is more or less constrained (Koch \& Perreault, 2019). Specific elite settlements may allow for a greater or lesser regulation of the extractive sector and the redistribution of its rents. For example, the presence of leftist governments may promote a greater 
redistribution of the sector's gains in the form of radical resource nationalism (Haslam \& Heidrich, 2018), and the orientation of the national business elite can make a difference when it comes to institutional arrangements intended to avoid the curse and take the route towards the developmental state (Haslam, 2016). The national economic context may matter when different extractive sectors coexist in one country. As Cisneros (this volume) shows for the case of Ecuador, the historical dominance of the oil sector has significantly hindered the effective regulation of the mining sector.

Even the way societies perceive the different expressions of the curse can matter and be consequential for institutional demands and potentially affect processes of institutional change. Moreno (this volume) discusses that the perception of corruption has no impact whatsoever on citizens' support for democracy in Bolivia and Peru (but in other countries of the Andean region). He hypothesizes that this results from the fact that societies in these two Andean countries seem to be more impervious to the existence of corruption. Since they are more accustomed to its presence, corruption might be less likely to affect the evaluation they make of the political system.

Finally, the opportunities for institutional change depend on the quality of democracy in place. While the literature has stressed the good governance of the sector and related areas as the remedy to the resource curse, it seems obvious that it only can be governed in a good way when the very political fundament is of a good quality. This includes a functional system of democratic representation, the presence of institutional checks and balances, and state agencies insulated from undue political influence capable of implementing rules of good governance. As shown by Schorr (this volume), if these conditions are lacking, reforms to tame the expressions of the resource curse may be difficult and come at high social, political, and even economic costs (as in the case of transparency reforms in Peru).

Context does not only matter nationally, but also on the subnational level where the local conditions may quite vary from those of the capitals hosting central governments and legislatures. In resource economies, particularly those territorial units where the resources are being extracted may be able to significantly shape how institutions are implemented or establish institutions that may mitigate or instigate the local expressions of the curse. In particular, the way in which subnational territories are linked to national and international political dynamics may affect how institutional change unfolds at the subnational level. As we have seen, national institutional dynamics are often subject to the effects of external actors; the same applies for subnational territories, such as the province of San Juan in Argentina, where external actors have played a greater role than the national government in setting up the environmental institutional frameworks in a federal country (Godfrid, this volume).

In a variation of the subnational resource curse, scholars should explore processes of institutional change and implementation in subnational units, extrapolating the conditions and factors that promote or prevent institutional change and effective implementation. 
In sum, different national or local contexts may allow for different institutional changes in different sectors at different moments. Exploring how these contexts shape the opportunities of institutional change aiming at the prevention or mitigation of the resource curse will spur our understanding of when and which change may be possible under the potentially adverse conditions of resource economies.

\section{Informal institutions in resource governance}

The resource curse approach has treated informal institutions as causes for the curse. In particularly, rent-seeking, corruption, clientelism, and patrimonialism have been stressed as informal institutions afflicting resource-dependent countries.

However, other scholarship has carved out the importance of informal institutions for understanding resource governance. It has been shown that informal institutions are present in many governance schemes and are not circumscribed to tradition and customary law (Farinós Dasí, 2008; Larson \& Soto, 2008; Pahl-Wostl, 2009). Distrust in the state and the institutions it enforces may also lead to the emergence of new informal practices. Often, formal and informal institutions interact, producing hybrid institutional frameworks (Sindzingre, 2006; Sardan, 2013; Damonte, 2021). Thus, the role of informal institutions in resource governance and how they prevent or promote the different expressions of the curse point strongly to another element that should be on the research agenda on institutional change in resource economies.

In this book, the chapter by Damonte reveals how agribusiness shaped the governance of their respective extractive regimes by imposing a series of informal practices that favor them. Moreover, the author shows how long-standing state territorial policies and current political dynamics shape the implementation of the formalization processes in Madre de Dios, creating what the author defines as hybrid institutional entanglements.

The hybrid character of governance schemes has been studied from various perspectives. Political scientists have explored several emerging hybrid modes of governance across the state-market community divisions in the environmental sector. These studies explore how state and non-state actors configure networks for co-management, public-private partnerships, and social-private partnerships in governing the environment and natural resources (Lemos \& Agrawal, 2006). From an anthropological perspective, studies have also stressed the formalinformal character of some hybrid modes of governance (Sindzingre, 2006; Sardan, 2013).

In the latter perspective, processes of institutional hybridization tend to take place when states command limited power over the territories they are supposed to govern and people lack trust in public institutions (Damonte, 2018, 2021). In cycles of extractive territorial expansion, new formal and informal rules surged through state impositions, institutionalization of local practices, and local appropriation and reinterpretation of state or corporate institutional initiatives 
in the context of constant state and corporative political negotiation with local powers to legitimate their presence and extractive rights.

\section{Final remarks}

This chapter laid out an agenda for future research on institutional change and performance in resource economies. After decades of focusing on the maladies that resource-dependent states tend to suffer, this research agenda revolves around the remedies to the curse: how institutions can be built and perform effectively, notwithstanding the potentially adverse dynamics resulting from resource dependency. On a general level, the book and the agenda developed in it propose that institutional changes ought to be analyzed as grounded in social processes. There may certainly be conditions that prevent institutional innovations in resourcerich regions, countries, and territories, but actual institutional developments will ultimately depend on the way social actors address the situation. Thus, it is fundamental to consider both conditions and contextual factors as well as social agency to fully understand institutional change as a cross-sectoral process.

In particular, the research agenda we have developed includes six thematic areas that focus on different aspects of institutional change and performance under the conditions of resource dependence. This agenda is meant as a first step; future research will certainly unveil other important aspects to be studied and analyzed.

One last word of caution is called for. The concept of the resource curse has been criticized for being stretched and often used synonymously with all sorts of failed development trajectories. In fact, in a region like the Andes, many problems affecting institution-building and performance cannot be traced back directly just to their resource dependency. Some are separate problems caused by other factors, and, indeed, many of them represent long-standing, deeper structural problems. These structural factors are similar throughout the region - as is the long-standing dependence on primary exports. They include limited state capacities (with the exception of Chile) and multidimensional inequalities that compromise significant power and knowledge asymmetries among social groups (Jelin et al., 2018). More recent developments such as the dramatically unequal effects of the global Covid-19 pandemic will strongly shape the possibilities for institutional change and performance in the region as well. In fact, many of these factors also operate in other low-income countries that do not possess vast natural resources to extract and export. Thus, research on the opportunities of institutional change must cautiously distinguish if these factors are operating and, if so, how they may reinforce effects produced by resource dependency.

The chapters in this volume focused on the latest boom period and the first years after the end of this boom in commodity prices. In the meantime, since the end of 2020, global commodity markets have begun an upswing, and some analysts, such as the investment bank Goldman Sachs, find signs that a new postpandemic boom cycle is beginning (Els, 2021). Without any doubt, such a new 
boom period would-again-significantly affect institutional arrangements and performance in the countries of the Andean arch. There will be plenty to study. Our research agenda contributes to explore the field and advance our understanding of inclusive and regulatory institutional change and performance in resource-dependent states.

\section{References}

Amengual, M., \& Dargent, E. (2020). The social determinants of enforcement. In D. M. Brinks, S. Levitsky, \& M. V. Murillo (Eds.), The politics of institutional weakness in Latin America (pp. 161-182). Cambridge University Press. https://doi.org/10.1017/9781108776608.007

Atria, J., Groll, C. L., \& Valdés Valencia, M. F. (Eds.). (2018). Rethinking taxation in Latin America: Reform and challenges in times of uncertainty. Palgrave Macmillan.

Bebbington, A. (2010). Extractive industries and stunted states: Conflict, responsibility and institutional change in the Andes. In K. Ravi Raman \& R. D. Lipschutz (Eds.), Corporate social responsibility: Comparative critiques (pp. 97-115). Palgrave Macmillan.

Bebbington, A., \& Bury, J. (2013). Subterranean struggles: New dynamics of mining, oil, and gas in Latin America. University of Texas Press.

Bogliaccini, J. A., \& Luna, J. P. (2016). Deflecting my burden, hindering redistribution: How elites influence tax legislation in Latin America. WIDER Working Paper 2016/92. UNUWIDER. https://doi.org/10.35188/UNU-WIDER/2016/135-2

Bonilla, H. (2020). Guano y burguesía en el Perú. IEP.

Bull, B., \& Aguilar-Støen, M. (Eds.). (2015). Environmental politics in Latin America: Elite dynamics, the left tide and sustainable development. Routledge.

Campbell, J. L. (2010). Institutional reproduction and change. In G. Morgan, J. L. Campbell, C. Crouch, O. K. Pedersen, \& R. Whitley (Eds.), The Oxford handbook of comparative institutional analysis. Oxford University Press.

Campello, D. (2015). The politics of market discipline in Latin America: Globalization and democracy. Cambridge University Press. https://doi.org/10.1017/CBO9781139599993

Campello, D., \& Zucco, C. (2021). The volatility curse: Exogenous shocks and representation in resource-rich democracies. Cambridge University Press.

Cárdenas, J. (2020). Exploring the relationship between business elite networks and redistributive social policies in Latin American countries. Sustainability, 12(1), 13. https://doi. org/10.3390/su12010013

Damonte, G. (2018). Mining formalization at the margins of the state: Small-scale miners and state governance in the Peruvian Amazon. Development and Change, 49(5), 1314-1335. https://doi.org/10.1111/dech.12414

Damonte, G. (2021). Limited state governance and institutional hybridization in alluvial ASM in Peru. Resources Policy, 72, 102118. https://doi.org/10.1016/j.resourpol.2021.102118

Dargent, E., \& Urteaga, M. (2016). Respuesta estatal por presiones externas: Los determinantes del fortalecimiento estatal frente al boom del oro en el Perú (2004-2015). Revista de Ciencia Política, 36(3), 655-677. https://doi.org/10.4067/S0718-090X2016000300003

Dietsche, E. (2007). Why the quality of institutions is not a cure for the 'resource curse'. The Journal of Energy and Development, 32(2), 262-282. www.jstor.org/stable/24813112

Durand, F. (2016). Cuando el poder extractivo captura el Estado: Lobbies, puertas giratorias y paquetazo ambiental en Perú. Oxfam.

Els, F. (2021, June 2). 120 year chart shows copper price supercycle only starting. Miningdotcom. www.mining.com/120-year-chart-shows-copper-price-supercycle-only-starting/ 
Fairfield, T. (2015). Private wealth and public revenue: Business power and tax politics in Latin America. Cambridge University Press.

Fairfield, T., \& Garay, C. (2017). Redistribution under the right in Latin America: Electoral competition and organized actors in policymaking. Comparative Political Studies, 50(14), 1871-1906. https://doi.org/10.1177/0010414017695331

Farinós Dasí, J. (2008). Gobernanza territorial para el desarrollo sostenible: Estado de la cuestión y agenda. Boletín De La A.G.E, 46, 11-32.

Haslam, P. (2016). Overcoming the resource curse: Reform and the rentier state in Chile and Argentina, 1973-2000. Development and Change, 47(5), 1146-1170. https://doi. org/10.1111/dech.12259

Haslam, P., \& Heidrich, P. (2018). The political economy of natural resources and development: From neoliberalism to resource nationalism. Routledge. http://gbv.eblib.com/patron/FullRecord. aspx?p $=4391725$

Jelin, E., Motta, R., \& Costa, S. (Eds.). (2018). Global entangled inequalities: Conceptual debates and evidence from Latin America. Routledge.

Jones Luong, P., \& Weinthal, E. (2009). Oil is not a curse: Ownership structure and institutions in Soviet successor states. Cambridge University Press. http://site.ebrary.com/lib/academiccompletetitles/home.action

Kapiszewski, D., Levitsky, S., \& Yashar, D. J. (Eds.). (2021). The inclusionary turn in Latin American democracies. Cambridge University Press. https://doi.org/10.1017/9781108895835

Karl, T. L. (2007). Ensuring fairness: The case for a transparent fiscal social contract. In M. Humphreys, J. Sachs, \& J. E. Stiglitz (Eds.), Initiative for policy dialogue at Columbia. Escaping the resource curse. Columbia University Press.

Koch, N., \& Perreault, T. (2019). Resource nationalism. Progress in Human Geography, 43(4), 611-631. https://doi.org/10.1177/0309132518781497

Kurtz, M. J. (2013). Latin American state-building in comparative perspective. Cambridge University Press. https://doi.org/10.1017/CBO9781139019668

Larson, A. M., \& Soto, F. (2008). Decentralization of natural resource governance regimes. Annual Review of Environment and Resources, 33(1), 213-239. https://doi.org/10.1146/ annurev.environ.33.020607.095522

Lemos, M. C., \& Agrawal, A. (2006). Environmental governance. Annual Review of Environment and Resources, 31(1), 297-325. https://doi.org/10.1146/annurev. energy.31.042605.135621

Levitsky, S., \& Roberts, K. M. (Eds.). (2011). The resurgence of the Latin American left. Johns Hopkins University Press. https://doi.org/10.1353/book.1866

Madariaga, A., Maillet, A., \& Rozas, J. (2021). Multilevel business power in environmental politics: The avocado boom and water scarcity in Chile. Environmental Politics, 8(1), 1-22. https://doi.org/10.1080/09644016.2021.1892981

Moore, M. (2004). Revenues, state formation, and the quality of governance in developing countries. International Political Science Review, 25(3), 297-319. https://doi. org/10.1177/0192512104043018

Orihuela, J. C. (2018). Institutions and place: Bringing context back into the study of the resource curse. Journal of Institutional Economics, 14(1), 157-180. https://doi.org/10.1017/ S1744137417000236

Pahl-Wostl, C. (2009). A conceptual framework for analysing adaptive capacity and multilevel learning processes in resource governance regimes. Global Environmental Change, 19(3), 354-365. https://doi.org/10.1016/j.gloenvcha.2009.06.001

Reis, E., \& Moore, M. (Eds.). (2005). Elite perceptions of poverty and inequality. Zed Books. 
Sardan, J.-P. O. de (2013). Embeddedness and informal norms: Institutionalisms and anthropology. Critique of Anthropology, 33(3), 280-299. https://doi.org/10.1177/0308275X13490307

Saylor, R. (2014). State building in boom times: Commodities and coalitions in Latin America and Africa. Oxford University Press.

Schilling-Vacaflor, A., \& Nolte, D. (2012). New constitutionalism in Latin America: Promises and practices. Routledge.

Sindzingre, A. (2006). The relevance of the concepts of formality and informality: A theoretical appraisal. In B. Guha-Khasnobis, R. Kanbur, \& E. Ostrom (Eds.), Linking the formal and informal Economy. Oxford University Press.

Soifer, H. D. (2016). The development of state capacity. In O. Fioretos, T. G. Falleti, \& A. Sheingate (Eds.), The Oxford handbook of historical institutionalism (pp. 182-191). Oxford University Press.

Streeck, W., \& Thelen, K. A. (2005). Institutional change in advanced political economies. In W. Streeck \& K. A. Thelen (Eds.), Beyond continuity: Institutional change in advanced political economies (pp. 1-39). Oxford University Press.

Vos, R. (2012). Economic insecurity and development in Latin America and the Caribbean. In J. A. Ocampo \& J. Ros (Eds.), The Oxford handbook of Latin American economics. Oxford University Press.

World Bank. (2019). Training for reform: Region profile of Latin America and Caribbean (LAC). World Bank. www.doingbusiness.org/content/dam/doingBusiness/media/Profiles/ Regional/DB2019/LAC.pdf 


\section{Index}

Note: Page numbers in italics indicate a figure and page numbers in bold indicate a table on the corresponding page. Page numbers followed by " $n$ " indicate a note.

accountability 7, 15, 146, 254

Acemoglu, D. 8

Acquatella, J. 42

Act 110098

advocacy coalition framework (ACF) 10

agents of institutional change 11, 11;

domestic and transnational challengers

as 15-17; governments, elites, business

12-14; international actors as 14-15;

ruling coalitions as $12-14$

Amazonía Viva 220, 225

American Declaration on the Rights of Indigenous Peoples (ADRIP) 104, 106

Americas Barometer 139n7, 139n10

Andean region 122-123, 136-137;

corruption and democratic institutions 124-125; democracy and citizen support 123-124; political corruption and anticorruption politics in 144-145; prior consultation implementation in Andean countries 107-108; research strategy 127-133; support for democracy and corruption in Latin America 125-126; see also Argentina; Chile; citizens; corruption; democracy; Ecuador; institutional change; Institutional change in extractive economies; Peru anti-corruption politics in Chile and Peru 143-145

apparent change 24, 172, 241, 242, 259; see also ecological modernization (Chile)

Arendt, H. 228

Argentina 47, 241-242; changes driven by social demands (2003-2014) 236-239; changes due to jolts caused by environmental accidents (2015-2019)
239-240; environmental control of mining in San Juan 234-236; institutional change 233-234, 241-242; institutions involved in mining 237; jolts defined 233; minerals exported 232; mining and environmental regulations (1993-2002) 235; political institutions 233; state institutions 233

Arsel, M. 71

asymmetrical sharing: described 48; on subnational fiscal inequality 49

Aylwin, P. 162, 163

Bachelet, M. 108, 145-148, 150, 164, 165, 170

Bagua conflict 257

Baguazo conflict 109

Bajo Alumbrera 232

Bebbington, A. 177

Black February 56

Black October 56

Black Swans 163-164

Blair, T. 15

Boege, V. 90, 92

Bolivia 16, 47; see also BONOSOL/Renta Dignidad; social policy in Bolivia; social protection in Bolivia

Bolivida 56, 61

Bolsa Escola-Bolsa Família (Brazil) 59

Bono Juana Azurduy (BJA) 59, 65; foreign revenues 66; FX reserves and international price of oil $\mathbf{6 5}, 66$

Bono Juancito Pinto (BJP) 59, 63-64, 64

BONOSOL/Renta Dignidad 56, 59, 61-63, 62

Bornschlegl, T. 18, 24, 255, 257 
boundary-spanning problems 161

Brack Commission 204-205

Brinks, D. 233, 241, 242

Brosio, G. 52n 4

business elites 13, 142

Camisea gas project 201

Campos, F. 19, 24, 261

Cárdenas, J. 13

Caria, S. 79

Carrasco, S. 19, 24, 241, 259

cash transfers as citizens' dividend of resource boom 54-67

Caso Caval 145, 147, 148

Caso Corpesca 145

Cerro Vanguardia 232

Chatterjee, P. 92

chichiquero miners 97,98

Chile 16; environmental system

24; resource curse and ecological modernization perspectives 179-181; see also ecological modernization (Chile); Environmental Courts (ECs, Cortes Ambientales [Chile]); environmental institutions (Chile); environmental subsystem change (Chile); extractive policy regime (Chile); political processes in Chile and Peru

Cisneros, P. 22, 255, 262

citizens 136; participation in informal institutions 135; support for democracy 123-125; support for democracy and corruption in Latin America 125-126

civil society organizations 210; Ecuador 76-77; Peru 109-110

cleanup projects $220,224-226$

Clements, K. 91

Colquiri mine in Oruro 41

Comisión de Alto Nivel para la Reforma Política (High-Level Commission for Political Reform [Peru]) 146

Comisión Regional del Medio Ambiente (COREMA) 164

commodity boom 39 ; during $41-43$; after 43; hydrocarbon sector 41-42; post-boom 51 ; royalties and taxes 42 ; traditional income taxes 42

conditional cash transfers (CCTs) 22, 59, 60

Consejo Asesor (Chile) 145-146

Consultative Mining Council (Consejo Consultivo Minero, CCM; Decree No. 1108) 237

Contribution for Regulation (Aporte por Regulación, APR) 206, 207
Coordinating Ministry for Strategic Sectors (Ministerio Coordinador de los Sectores Estratégicos, MICSE [Ecuador]) 80, 84n9

Coordinating Ministry of Strategic Sectors (MICSE) (Ecuador) 81

Cornejo Leaks scandal 208, 214n27

corporate social responsibility (CSR) programs 13, 106, 256

Correa, R. 71, 72, 76-82, 84n9, 125

corruption 23, 128; and anti-corruption politics in Andes 144-145; citizens' participation in informal institutions 135; defined 144; democratic institution and 124-125, 133-134; economic cycle 133-134; increasing engagement in informal participation mechanisms 132-133, 132-133; large-scale 136; Latin America 125-126; perception of 138n5; political party 135 ; reducing engagement in formal participation mechanisms 130-132, 131; reducing support for democracy 128-130, 129-130; research strategy 127-133; right to vote and participating in political party 134-135; on support for democracy 134

Damonte, G. 20, 22, 23, 138n1, 257, 261

Dargent, E. 238, 241, 257

Dávalos, S. 145

Declaration of Lima 201

democracy: citizen support and 123-125; corruption and democratic institutions 124-125; support and corruption in Latin America 125-126; see also corruption

democratic institution 124-125

democratic legitimacy 128

development: beyond apparent of Chilean environmental institutions (1990-2019) 158-172; institutional 21; sustainable 7; see also development model

development model: extractivist models in Andes 251; post-neoliberal 218-219, 221

Diálogo minero see Mining Dialogue (Diálogo minero) (Ecuador)

"died in Congress" 150

Dietsche, E. 253

Domínguez Martín, R. 79

dysfunctional hybridizations 92

ecological modernization (Chile) 161; apparent policy change and regime resilience 164-165; CONAMA and system of environmental impact 162-163; 
emerging conflicts and latent institutional crisis 163-164; political accommodation 162; second wave of 164-165

ecological modernization theory 180

Ecuador 16, 22; Constitution Montecristi 219; hydrocarbon law reform 42; renegotiation of oil contracts 41; see also hydrocarbon sector in Ecuador; mining sector in Ecuador (2002-2019)

effective implementation: chances for 20; institutional design and 258-261; of institutions 18-19; lack of 18

El Comercio 73, 205

elites 12-14; business 13, 17, 254, 255, 257; economic 73, 77, 142, 165-166; institutional change 12-14; professional 199, 203; resistance 254, 258

El Universo 73

Engel Commission 145, 146

Engel, E. 145, 153n17

Environment Act (2005) (Peru) 98

environmental accident 239-241

Environmental Assessment and

Enforcement (Organización de Evaluación y Fiscalización Ambiental, OEFA [Peru]) 198-202; Brack Commission 204-205; enforcement power 206-208; fines collected (2011-2017) 208; old practices and weakening of power 204-211; scope of authority defined 206; SENACE definition of scope of authority 206; situation after paquetazo law 209-211; SNMPE and MINEM 204

Environmental Assessment Service (EAS, Servicio de Evaluación Ambiental [Chile]) 178, 187

Environmental Courts (ECs, Cortes Ambientales [Chile]) 178-179, 181, 193-194; cases heard in 185-190; cases processed by 182 ; claims by type of resolution 191; legal claims 182; legal claims by type of claimant, respondent, and reasons from Article 17, 2013-2016

188-189; legal claims by type of user and economic sector 186; non-project holder category 184; number of legal claims by type of user 185; organized $v s$. non-organized civil society $185-186$; origins and operation of 183-184; parties taking cases 184-185; project holder category 184; resolved cases 190-192; users identified as claimants 182-183
Environmental Courts (EC) in Chile 19, 24, 178, 182, 259, 261

environmental damages 224, 226, 227; see also reparación integral

Environmental Framework Act (Chile) 178

environmental governance, international 180; Peru 199

Environmental Impact Assessment System (EIAS) (Chile) 178, 182, 190

Environmental Impact Evaluation System (SEIA) (Chile) 161-164

environmental institutions (Chile) 24, 177-179; compulsory public participation 178; institutional colonization 179, 181, 192; institutional counterbalance 193; resource curse and ecological modernization perspectives 179-181; social license 180; technical procedures 180

environmental law enforcement 222-227

Environmental Ministry in Peru 19, 24, 259

environmental monitoring institutions 25 ; see also Argentina

environmental protection 162, 165 , 257; evolution of fiscal expenditure in 171; and institutional change in Peru 199-202; see also ecological modernization

Environmental Quality Standards (Estandares de Calidad Ambiental, ECA [Peru]) 207

environmental subsector 19, 164, 169, 259 environmental subsystem change (Chile) 158-159, 171-172; boundary-spanning problems 161; ecological modernization trajectory and determinants 161-165; extractive policy regime 165-171; path dependence, tensions and apparent policy change 159-161; policy subsystem and regime 160; public policies 160; sectoral or intersectoral character of policies 160-161

Environment Ministry (Chile) 161

Espacio Público (Public Space) 148, 153n17, 153n18

Evia, P. E. 22, 23, 253, 255, 259

extractive industries transparency initiative (EITI) 15, 256

extractive institutions 8,255

extractive policy regime (Chile): approved mining projects 167; budget evidence of weak position of environmental 
institutions 171; business power 169; environmental policy under pressure, high-profile conflicts $v s$. general trend 169-170; extractive projects, continuity in policy regime 165-169; fiscal expenditure in environmental protection 171 ; investment amounts mining projects approved according to presidential term 168; socio-territorial conflicts 168 ; status of mining projects 166

extractivism 115, 165, 222, 227, 228

extractivist imperative debate 22

Falleti, T. G. 106, 112

Fernandez, C. 125

Ferreira, F. H. G. 59

Figueroa, L. 19, 20, 24, 257, 261

first possession rights 97

fiscal reforms 22, 39-41, 50-52, 258-260; commodity boom 41-43; fiscal revenues from nonrenewable natural resources 48, 48-49; objectives 39; participation in inequality of subnational tax revenues 49; revenue collection instruments and 41; tax collection from nonrenewable natural resources 44, 45; tax revenues from exploitation of nonrenewable natural resources 44, 46-50

Flemmer, R. 16, 23, 114, 255, 259

Fondo Social de Emergencia-Social

Emergency Fund (Bolivia) 55

formal institution $8,89,122,128,134-135$

fragmented layering process 159

free, prior and informed consent (FPIC) 104, 106-107

Frei doctrine 163

Frei, E. 163, 164

Fruta del Norte project 79, 80

Fuerza Popular (Peru)147

Fujimori, A. 109, 145

Fujimori, K. 146, 147

Fundación Ciudadanía Inteligente (Intelligent Citizenry Foundation [Chile]) 148

García, A. 109, 198, 200, 204

García Miró, A. 207, 208

General Mining Act (Peru) 97

Gini coefficient 49

Gioja, J. L. 234, 236, 242n3

Global Barometer on Corruption in Latin

America and the Caribbean 2019144

globalization 10

glocalization 160 glocalized mobilizations 203

Godfrid, J. 15, 18, 25, 257

Gold, K. 79

Gómez, H. 207, 209

good governance 6-7, 262

governance schemes: driven by social actors 90; hybridization of 100

greening process 235

green state 12,15

guest miners 97

Gutierrez, L. 75, 76

Hale, C. R. 108

Haslam, P. 7, 13, 253, 256

Heidrich, P. 253

Helmke, G. 89

Héroes del Chaco 57

heterodox models 115

high-quality institutions 6

historical debts 106-107

Huanuni tin mine 41

Humala, O. 109, 110

hybrid governance model 22-23

hybrid institutional entanglements 263

hybrid institutions 88-89; collaboration of formal and informal institutions 91; conceptual framework 89-92; dysfunctional hybridizations 92 ; entanglements 91-92, 99-100; fragile states 91; hybridization of governance schemes 100; hybrid political orders 91; institutionalization of informal institutions 99; institutionalized practices as entanglements 92-99; social actors 90

hybridization 92, 100, 159

hybrid regimes 112

Hydroaysén project 178

hydrocarbon sector in Ecuador 218-220; politics of institutions 227; progressive institutions 228; progressive public institutions 227; reparación integral and environmental law enforcement 222-227; resource boom and institutions, the Left Turn 220-222, 227

Hydrocarbons Law 57, 208, 209

Ica valley (Peru) 92-96

illegality: formal cases 193; miners 99; mining activities 98

ILO C169 106-108, 110

IMF 14

imported institutions 20

inclusive institutions 8-9 
indigenous mobilizations 105, 108

inequalities: Bolivian interdepartmental 47 ; income 3 ; poverty and $4,54,66$; regional 27, 39, 40; social 3, 5, 7, 21, 92, 142, 144, 218; subnational fiscal 49, 49-50; territorial 27, 39

informal institutions 8, 89-92, 99-100, $122,124,132,135,263-264$

informality 67, 89, 91, 97

institutional change: ACF 10; in Andean resource economies 11-17; critical junctures 9; and environmental protection in Peru 199-202; isomorphism 9-10; promotion in Chile and Peru 146-149, 151; social mobilization 10; transnational activism and advocacy 10-11; see also agents of institutional change; Argentina; institutional change in extractive economies; social policy in Bolivia institutional change in extractive economies 251-252; beyond government, non-state actors and international organizations role 254-256; and governments in resource economies 252-254; and implementation 258-261; informal institutions in resource governance 263-264; national and subnational levels 261-263; patterns, sequencing, and timing of 256-258

institutional colonization 179, 181, 192 institutional complexities 259, 260 institutional design 179, 181, 190, 252, 258-261

institutional developments 21

institutional emergence 8-11, 22-23, 260

institutional isomorphism 9-10, 24, 255, 260-261

institutionalized practices as hybrid institutional entanglements: agribusiness companies' extraction of scarce groundwater resources in Ica 92-96; map of agricultural activity on aquifers in the Ica valley 93; map of mining activity in Madre de Dios 96; small-scale miners' access to gold alluvial deposits in the Amazonia 96-99

institutional no-fit 255, 260-261

institutions: defined 89; effective implementation of 20; extractive 8; formal 89; formal and informal 8; implementation 260; inclusive 8-9; ineffective enforcement 19-20; informal 89-90; from institutional adoption to institutional performance 17-21; non-enforcement 17-18; non-punitive sanctions 20; sanctions 20; social acceptability 20-21; see also institutional change; institutions in Peru

institutions curse 6

institutions in Peru 198-199, 212-213; institutional change and environmental protection, OEFA 199-202; old practices and weakening of OEFA's power 204-211; weakening of environmental institutions to protect environment 204; see also isomorphic institutional changes (Peru)

integral reparation see reparación integral

Integrated Water Resources Management concept 15

Inter-American Development Bank 201

Interdisciplinary Commission for Environmental Assessment of Mining (Comisión Interdisciplinaria de Evaluación Ambiental Minera, CIEAM; Decree No. 1815) 237

international actors as agents of institutional change 14-15

International Bank for Reconstruction and Development 234

International Council on Mining and Metals (ICMM) 256

international environmental governance 180

International Monetary Fund 74 isomorphic institutional changes (Peru) 199, 212-213; and lack of social support 211-212; and persistent resource curse 202-204

isomorphism 9-10

Japan International Cooperation Agency (JICA) 235

Jiménez, J. P. 22, 23, 52n4, 253, 258, 259

jolts: changes caused by environmental accidents (2015-2019) 239-240; defined 233

José María project 236

Kucinsky, P. P. 146

La Farfana 163

La Pampa 98

Larsen, P. B. 113

Latin America 59; business elites 13; green state 12; support for democracy and corruption in 125-126; tax collection 
from nonrenewable natural resources 44 , 44,45 ; tax revenues from exploitation of nonrenewable natural resources 44-50; see also Argentina; Chile; Peru

Latin American Public Opinion Project (LAPOP) 127, 139n7

Law 19300 161, 166

Law 30230 207-209, 208

Lerman, R. 49

Levitsky, S. 89, 238, 241

Ley de Plusvalía (Law on Capital Gains) 80 Llurimagua 82-83

local actors 17, 20, 88, 166

Madariaga, A. 171

Madre de Dios 96-99, 112, 255, 263

Maillet, A. 19, 24, 241, 259

Mandate 477

margin of sovereignty 42

Marshall Plan 59

Maximum Permissible Limits (Límites Máximos Permisivos, LMP [Peru]) 207

Mayorga Alba, E. 208, 209

Mesa, C. 56

Meyer, J. W. 203

miners 97; chichiquero 97, 98; guest 97; holder 97; illegal 99; peons 97; smallscale 99

mining 236

Mining Big Brother program 240

Mining Chamber of Ecuador (CME) 76

Mining Chamber of San Juan (Cámara Minera de San Juan) (Argentina) 237

Mining Dialogue (Diálogo minero) (Ecuador) 76

Mining Environmental Management Agency (Peru) 200

Mining Mandate (Mandato Minero) (Ecuador) 77

Mining Royalties Law (Peru) 52n3 mining sector in Ecuador (2002-2019) 70-71, 83-84; administrative dimension $73,80-83$; case $71-72$; civil society organizations 76-77; economic dimension 73, 78-80; location of oil extraction and metal mining projects 75 ; metal mining sector 71-72; method 73; mining companies and local communities, conflicts between 77-78; oil rounds 82; oil sector and 72-76; policy goals and instruments 76; policy ideas 72; political dimension $73,76-78$; results 73-74; socio-environmental conflicts 78; theoretical background 72-73
Mining, the Argentine College of Mining Engineers (Colegio Argentino de Ingenieros en Minas) 237

Ministry of Energy and Mines (MEM): Ecuador 74, 84n2, 84n3; Peru 110-111

Ministry of Mines and Petroleum (Ministerio de Minas y Petróleos, MMP) (Ecuador) 80

Ministry of Mining and Energy (Ministerio de Energía y Minas, MINEM [Peru]) 198-200, 204-206

Ministry of Nonrenewable Natural Resources (Ministerio de Recursos Naturales no Renovables, MRNNR [Ecuador]) 80-81

Ministry of the Environment (Ministerio del Ambiente, MINAM [Peru]) 111, 178, 198, 200, 201

Mirador project 76, 80

Moraga, P. 184

Morales, E. 56, 57, 59, 61, 63, 107, 125

moral incapacity concept 148

Moreno, L. 78, 82, 83, 84n9

Moreno Morales, D. E. 16, 23, 258, 262

Multidisciplinary Environmental Assessment Commission for Mining (Comisión Evaluadora Multidisciplinaria Ambiental Minera; 1679-2006 M) (Argentina) 237

Muñoz, P. 153n17

Murillo, M. V. 238, 241

National Coordinator for the Defense of Life and Sovereignty (CNDVS) (Ecuador) 77

National Corporation of Environment (CONAMA) (Chile) 161, 162

National Development Plan 2009-2013 (Ecuador) 79

National Environmental Certification Service (Servicio Nacional de Certificación Ambiental, SENACE [Peru]) 205-206, 210

National Environment Fund (Fondo Nacional de Medio Ambiente, FONAM [Peru]) 210

National Mining Company (Empresa Nacional Minera, ENAMI-EP [Ecuador]) 78, 80-83

National Plan for the Formalization of Artisanal Mining (PNFMA) (Peru) 98

National Society of Mining, Petroleum and Energy (Sociedad Nacional de Minería, Petróleo y Energía, SNMPE [Peru]) 204 


\section{Index}

National System of Environmental Impact Assessment (Servicio de Evaluación de Impacto Ambiental, SEIA) 210

neoliberal multiculturalism 108

neoliberal resilience 160

New Mining 207

NGOs 148-149

no-go zones concept 16

nonrenewable natural resources: fiscal revenues from 48, 48-49; tax revenues from exploitation of $44,46-50$ non-state actors 20, 252, 254-256

North American Free Trade Agreement (NAFTA) 162

Nueva Mayoría (SOQUIMICH case [Chile]) 145

Observatorio Anti-corruption (Anti-corruption Observatory [Chile]) 149

Observatorio de Integridad (Observatory of Integrity [Peru]) 149

Observatorio del Gasto Fiscal (Observatory of Fiscal Spending [Chile]) 148

Odebrecht case 146

OECD 14, 24, 165, 169, 178

oil sector: economic dimension 78-79; and mining sector in Ecuador 72-76

Ojo Público 209

Olivier de Sardan, J.-P. 90

Organic Hydrocarbons Law (Law 26221) (Peru) 210

Orihuela, J. C. 7, 12, 15, 19, 200

Ospina Peralta, P. 221

Palacio, A. 75, 76

paquetazo ambiental (Peru) 207, 209-211

Paredes, M. 19, 20, 24, 200, 257, 261

Participatory Environmental Monitoring Program 210

participatory processes 104

Pascua Lama mining project 167, 178, 236

pasivos ambientales 223, 224, 226

peons 97

Peru 16; conflicts in 211; democracy without parties 152; prior consultation implementation in 109-112; see also political processes in Chile and Peru

Peruvian Environmental Ministry 19

Peruvian Society of Environmental Law

(Sociedad Peruana de Derecho Ambiental, SPDA) 204

Petroamazonas EP 225, 226

Petroecuador EP 225

PetroPeru 210
Pierson, P. 161

Piñera, S. 113, 165, 167

Pinochet, A. 145, 151, 158, 161, 162

plan of the integral restoration of pasivos ambientales (PRIPA) 225

poison pills 112

policy subsystems 160

political accommodation 162

political institutions (Argentina) 233

political myopia 6

political processes in Chile and Peru 23, 142-144; corruption and anticorruption politics in Andes 144-145; democratic institutions 151-152; institutional change 146-149, 151; parties as electoral vehicle 152; transparency politics 145-146, 152

politics 17-20, ses also political processes in Chile and Peru; actors 6, 90, 172; business elites as political players 13; domestic 165; domestic and transnational challengers as agents of change 15-17; and fiscal decentralization 15; hybridity as tool 92; informal political institutions 124; institutions 233-240; of institutions 227; parties 134-135; political accommodation 162; political dimension in Ecuador 76-78; political myopia 6; political settlement approach 8 pollution 207 poverty 142 power: agents of institutional change 11; business power in Chile 169; as constitutive element of institutional emergence 8-9; de facto 203;

Environmental Courts (Chile) 183, 193; formal institutions 202; institutions as products of specific power relations 8; old practices and weakening of OEFA's power (Peru) 204-211; small-scale miners 99

prior consultation 104-105, 115-116; FPIC as institutional innovations and 106-107; implementation in Andean countries 107-108; implementation in Peru 109-112; implications for Andean countries 112-115; of indigenous people 23

Proética (Peru) 148, 149

Professional Council of Geological Sciences (Consejo Profesional de Ciencias Geológicas) (Argentina) 237

Program of Environmental and Social Reparation (Programa de Reparación 
Ambiental y Social, PRAS [Ecuador]), limits and enforcement of reparación integral 224-227; lines of work 224; see also Sistema de Indicadores Ambientales $y$ Sociales (SIPAS)

Progresa-Oportunidades (Mexico) 59

project to eliminate contaminated ditches and clean-up of oil spills in the Amazon district (PEPDA) 220, 224

Provincial Environmental Management Unit for Mining (Unidad de Gestión Ambiental Minera Provincial, UPGAMP, 1998) (Argentina) 235

Pulgar-Vidal, M. 202, 204, 205, 209

punctuated equilibrium model 9

Quispe, F. 56

Rabi, V. 19, 24, 261

radical resource nationalism 262

Ralco hydroelectric plant 163, 178

redistribution $47,73,79,254$; fiscal schemes during boom period 258; institutions 21, 251, 253; new policies 22; radical resource nationalism 262; and social policies 4

Renta Dignidad see BONOSOL/Renta Dignidad

rents 22; distribution of 12; extractive sectors 257; flow from guano boom (Peru) 253; natural resource rent sharing 46-47; rent-seeking 6, 13, 18, 67, 143, 177, 263; of resource sector 253; sharing in favor of subnational governments 46 reparación integral 25, 219; defined 222-223; described 222; in hydrocarbon sector 219, 222; oil extraction history and 222-224; pasivo ambiental 223; PRAS 224

Research Center for the Prevention of Mining and Industrial Pollution (Centro de Investigación para la Prevención de la Contaminación Minero-Industrial, CIPCPAMI, 1996) (Argentina) 235, 238

resource curse 3, 218; concept of 264; good governance 6-7; maladies and remedies 5-7; political myopia 6; statesociety relations 6 ; see also subnational resource curse

resource economies 3; governments and institutional change in 252-254; institutional change in Andean region $11-17$

resource governance: and environment protection 15; informal institutions in 263-264; prior consultation to reform 106-107, 114, 116

resource nationalism 253-254

resources boom: cash transfers as citizens' dividend of 54-67; institutional

developments in Andean countries 21; see also institutional change; social policy in Bolivia

Río 1992 Summit 162

Río Blanco project 78

Rio Convention 14, 178

Riofrancos, T. 106, 112

Rios, M. 153n17

Robalino, D. 59

Robinson, J. A. 8

Rowan, B. 203

Ruelas, I. 52n4

Sagasti, F. 148

Sánchez de Lozada, G. 55, 56

San Juan 241, 257; see also Argentina

Saylor, R. 13, 253, 256

Schilling-Vacaflor, A. 114

Schorr, B. 23, 138n1, 262

Secretary of Hydrocarbons (SHE) 108

Sistema de Indicadores Ambientales y Sociales (SIPAS) 224

Sistema General de Regalías 47

social activism 10

Social and Environmental Reparation

(PRAS) program 24

Social Emergency Fund 55

social license 180

social policy in Bolivia 54, 66; BONOSOL 56; domestic reforms and global boom 55-59; fiscal balance and government expenditures and revenues 58 ;

hydrocarbons' taxes under different regimes 57,57 ; poverty rates 55 ; public revenues 57

social policy reforms $259-260$

social protection floor (SPF) 59

social protection in Bolivia 54-55, 66-67; Bono Juana Azurduy (BJA) 59, 64-66, 65; Bono Juancito Pinto (BJP) 59, 63-64, 64; BONOSOL/Renta Dignidad 59, 61-63, 62; CCTs 59; unstable finances 60-61

soft law 106

Sovereign Wealth Funds 13

state 20-21; democratic reform of $84 \mathrm{n} 9$; fragile states 91 ; green state 12 , 15,24 ; identification of state as weak 91-92; institutions, reproduction, and institutional change 233-240; 


\section{Index}

organized into policy sectors $72-73$; prior consultation in Andean countries 108; program 24; rule of law 18; see also Andean region; state enforcement state enforcement: of environmental sanctions 207; limits to reparación integral and environmental law 222-227; see also reparación integral

state institutions (Argentina) 233

Strategic Ecuador 80

Streeck, W. 261

subnational resource curse 5-6

Superintendence of the Environment

(Superintendencia de Medio Ambiente, SE [Chile]) 178

Supervising Organism for Investments in Energy and Mining (OSINERGMIN) (Peru) 205-207

sustainability: fiscal sustainability of the

Bolivian social policy 55, 59-66;

institutionalization (Ecuador) 218-228 sustainable development 7

Talcott, P. 138n1

Tanaka, M. 153n17

technical procedures 180

Thelen, K. 261

Torres Wong, M. 114

transnational advocacy 16-17

transparencia (transparency [Peru]) 148, 153n17

transparency: CIEAM 237; in extractive sector 15; political transparency in
Chile and Peru 23, 143, 145-146, 149-152; reforms/reformers 258; see also transparencia (transparency [Peru])

Transparency International (Peru) 148, $153 n 4$

Tuesta, F. 146

United Nations Declaration on the Rights of Indigenous Peoples (UNDRIP) 104

United Nations Framework Convention on Climate Change 162

UN Rio Convention 14, 178

unwanted change 109-112

urgency legislation 147

Urteaga, M. 238, 241, 257

variable operationalization 128, 137-138 veedorías ciudadanas (Peru) 149

Vice Ministry of Mines (Viceministerio de Minas) (Ecuador) 81

Vizcarra, M. 146-148, 150, 152, 153n11 voting 135

War over Gas 56

Weyland, K. 20

window dressing institutions 17, 19, 238, 256, 259

World Bank 14, 74, 201

Yacimientos Petroliferos Fiscales Bolivianos (YPFB) 55-57

Yitzhaki, S. 49 